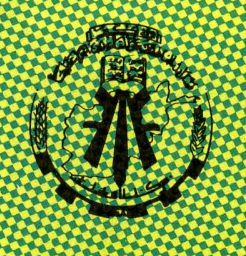

\title{
(reama $[\stackrel{\circ}{\infty}$
}

mom

$4 Y$

HU H H H

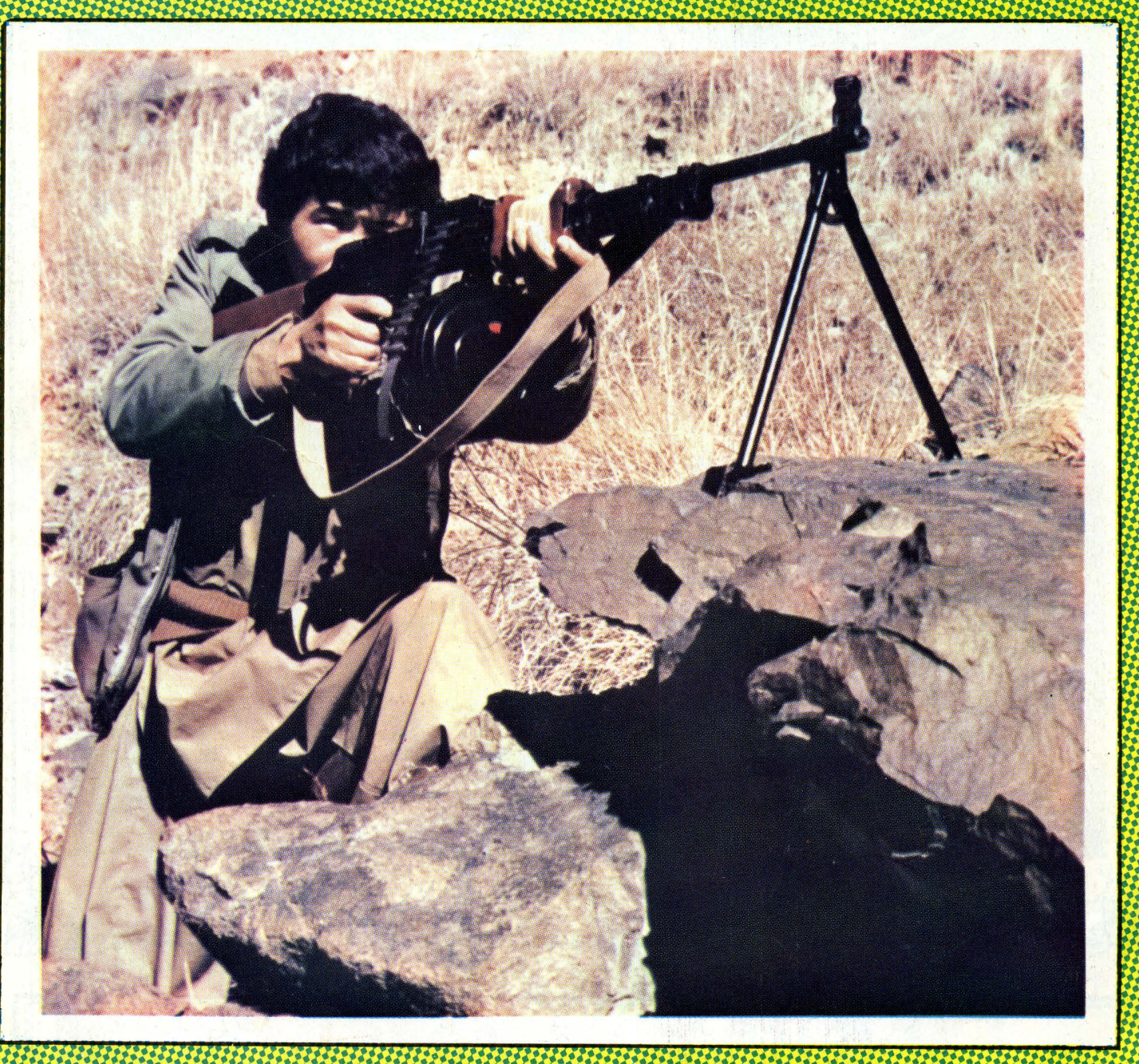

\begin{tabular}{|c|c|}
\hline 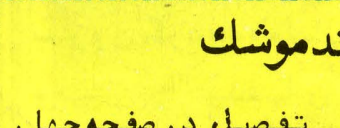 & 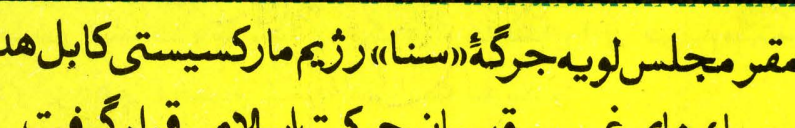 \\
\hline تفصيل , & 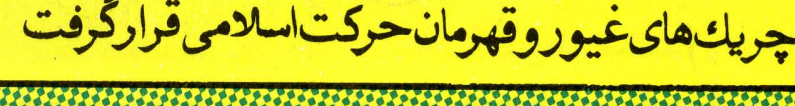 \\
\hline
\end{tabular}



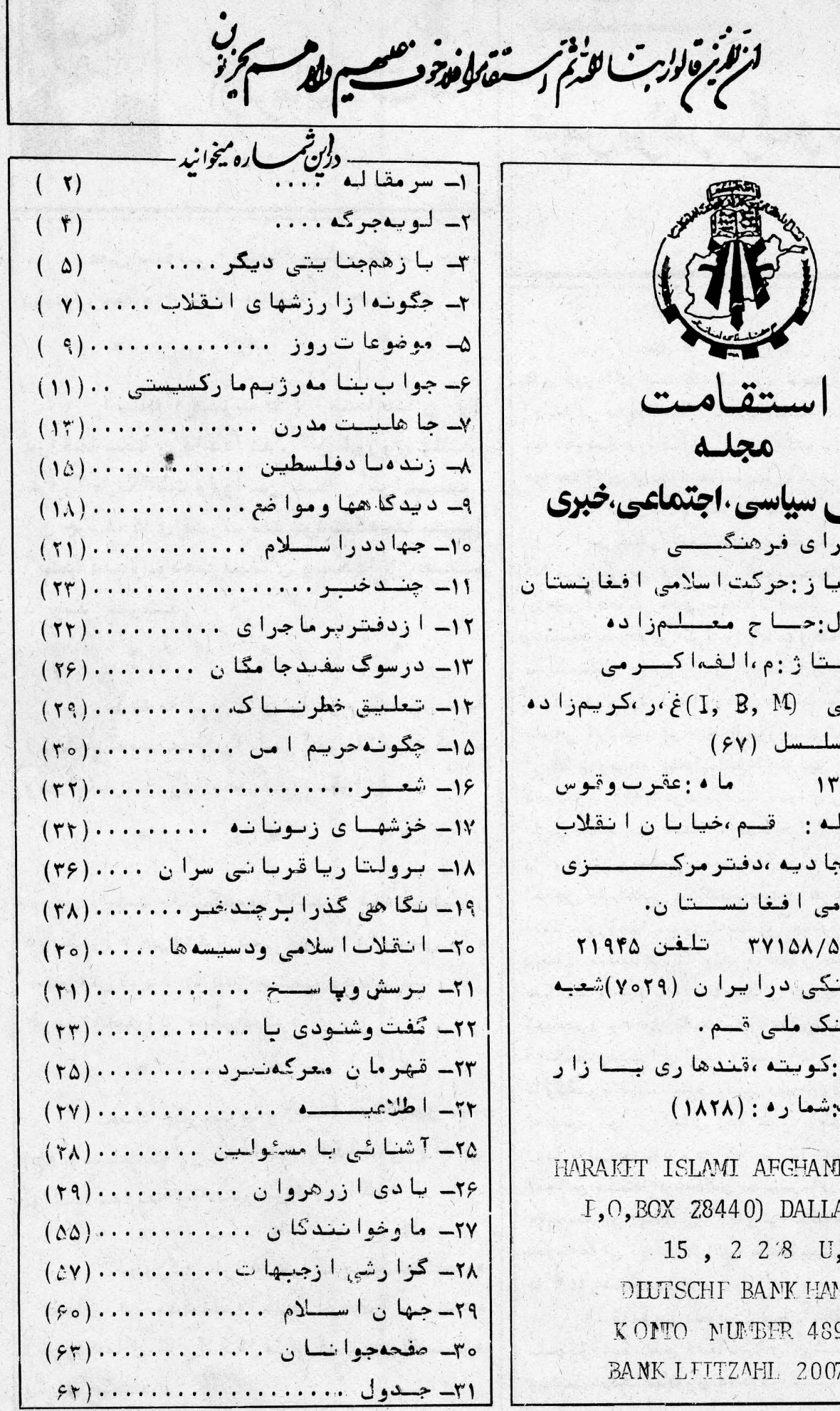

رينى سياسى ،اجتماعى، خبرى

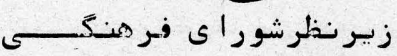

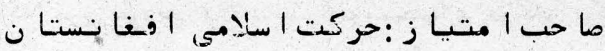

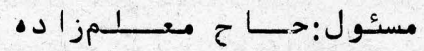

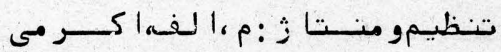

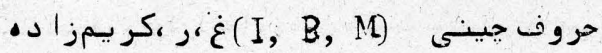

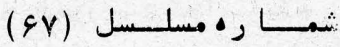

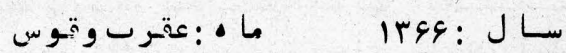

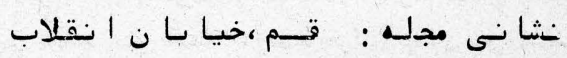

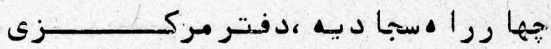

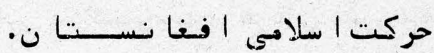

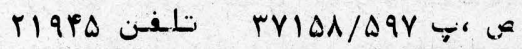

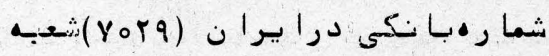

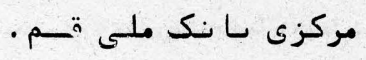

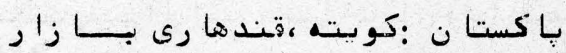

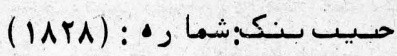

HARAJTT ISLAMT AFGHAMISTAN I, $O$, BOK 28440) DALLAS TX $15,22: B \quad U, S, A$ DUUSCHF BANK HAMPURC K ONTO NUPFP 4896301 BANK LFTTZAHI. 20070000 


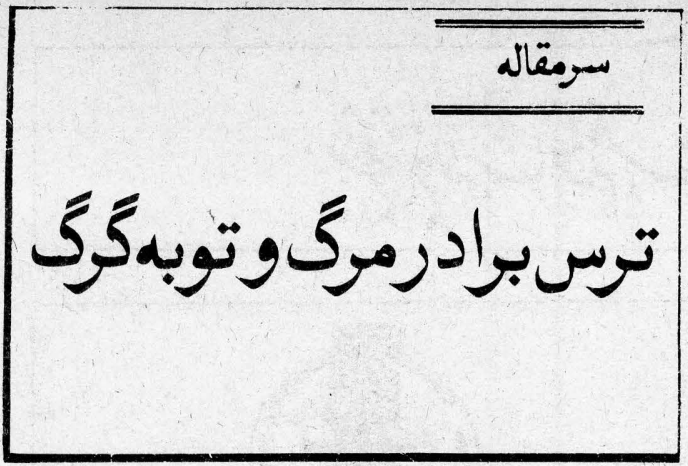

ضرب الـمثل ها كيكمد ر زبا ن مرد معوا ما زكذشته

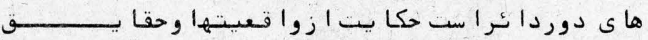

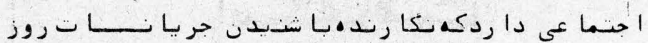

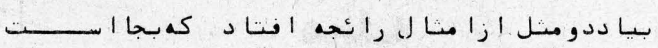

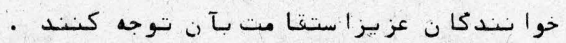

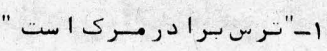

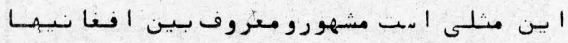
كما مروزبروضع فلاكت با ركمونسيستها ى خو نخوا روذلهيل

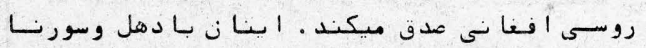

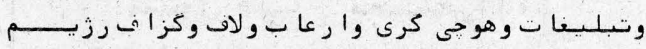

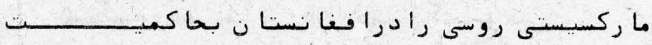

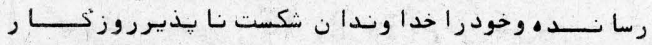

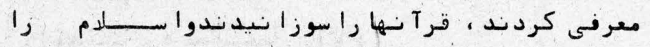

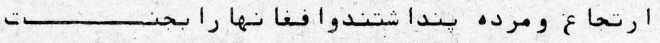

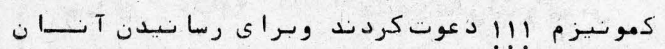

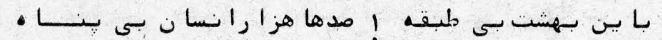

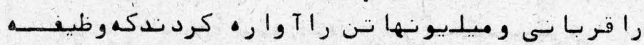

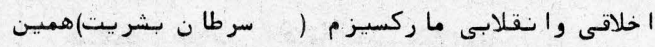

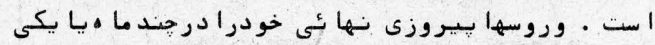

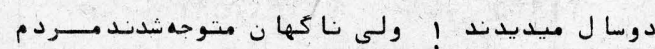

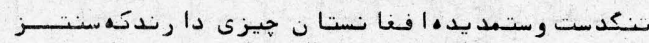

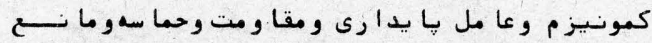

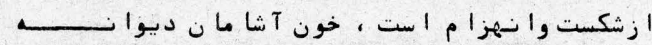

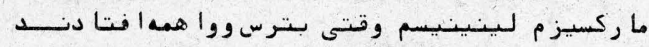

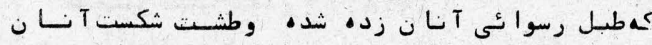

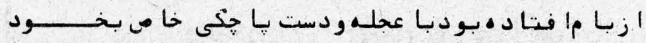

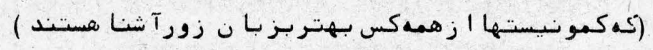

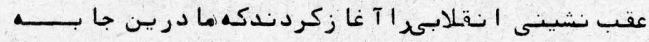

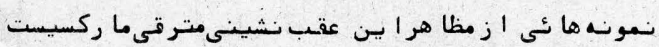

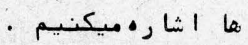

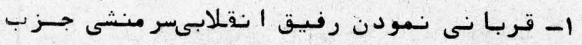

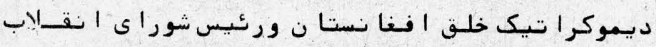

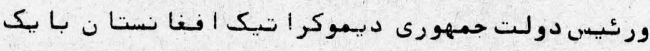

ازفومايشات|مام

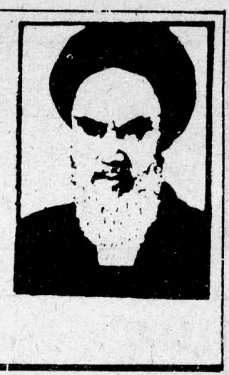

عقل سيا سبى اتتبضاء ميكندكهم ما ا هروز

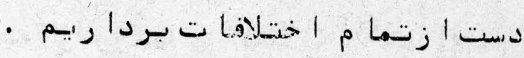

$$
\begin{aligned}
& \text { * }
\end{aligned}
$$

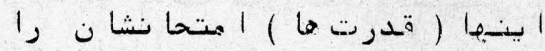

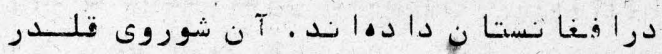

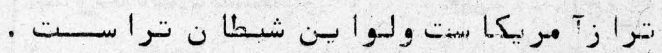

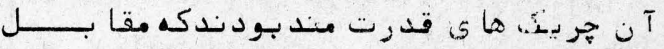

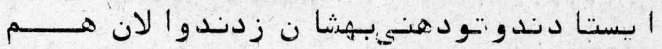

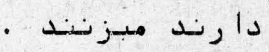

米

*

*

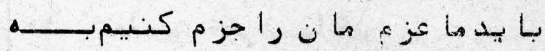

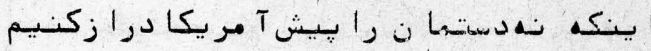

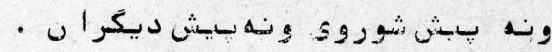
*

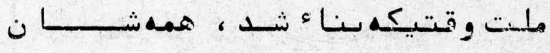

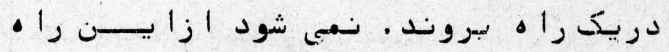

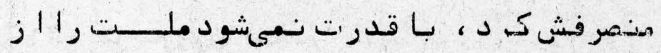

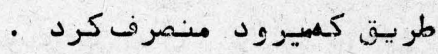
*

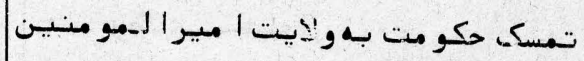

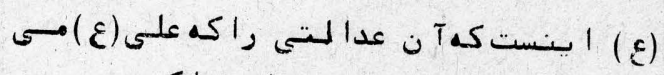

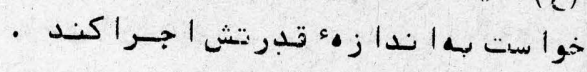
* * *

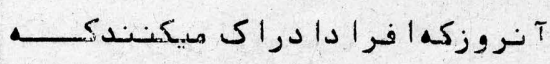

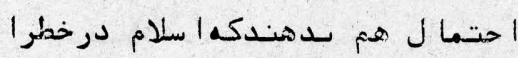

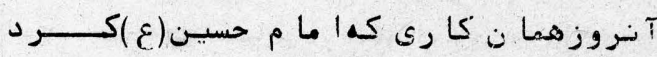
با بيد بكند 


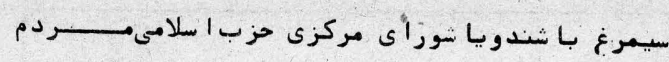

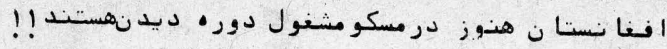

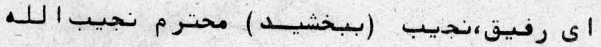

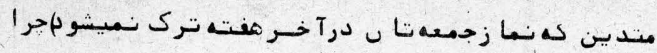

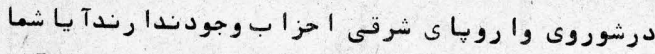

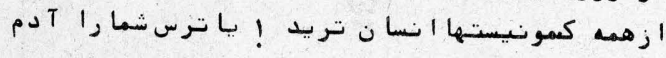

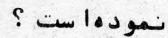

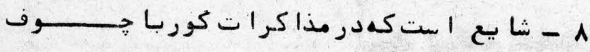

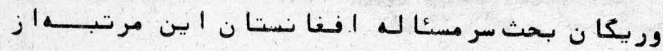

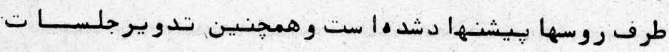

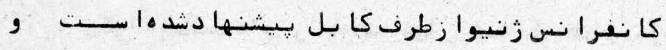

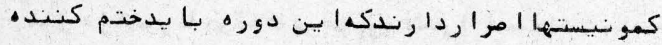

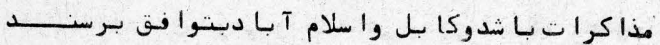

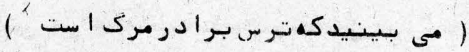

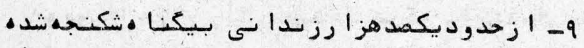

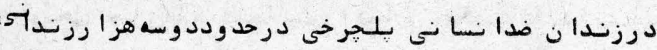

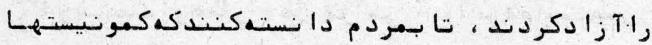

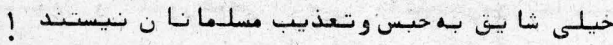

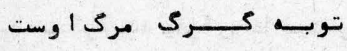
$-r$

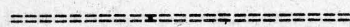

شما تا كنون كرى غيردرنده، راديدها يدك

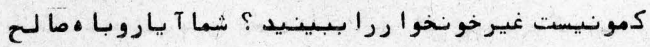

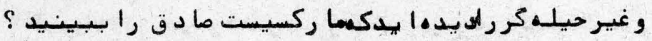

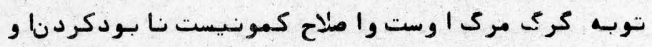

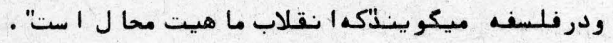

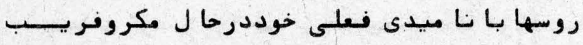

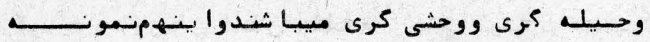

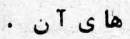

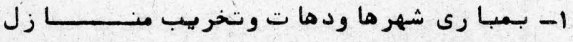

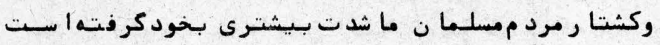

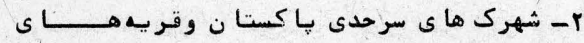

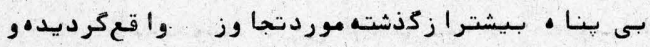

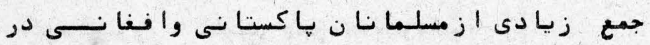

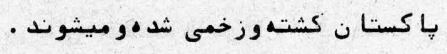

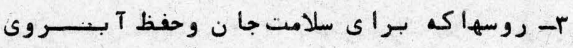

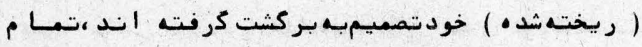

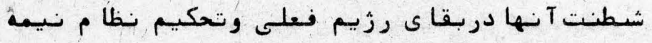

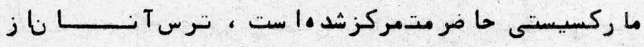

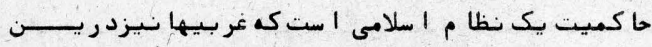

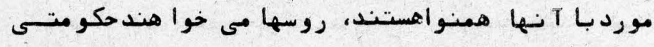

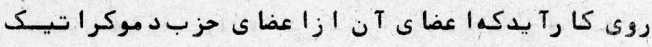

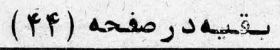

دو متر اللقا ب وعنا وينا نقلابىديكر به شيو هما ركسيستى

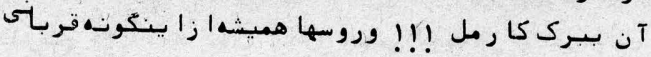

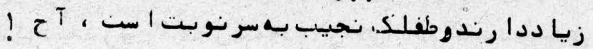

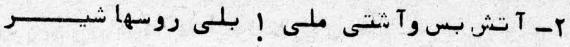

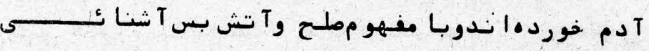

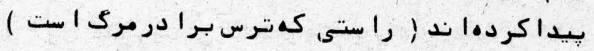

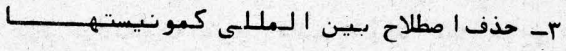

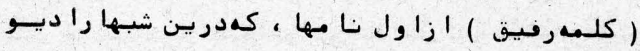

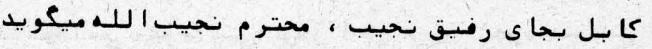

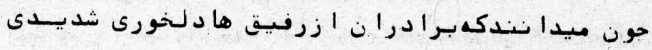

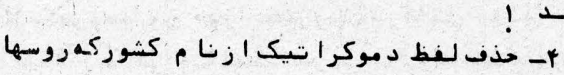

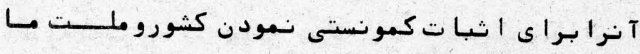

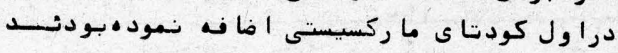

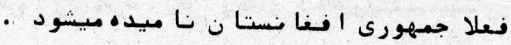

* آ يا تحلحيل نها تئ يـن جملـها عـالان

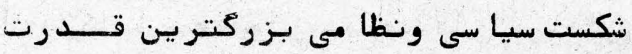

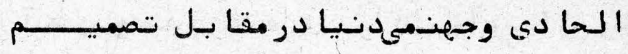

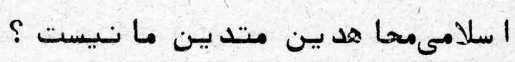

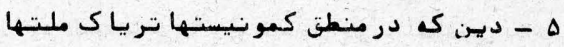

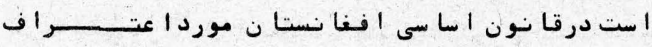

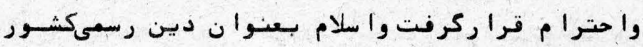

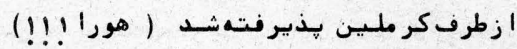

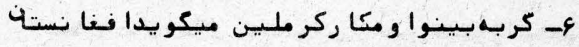

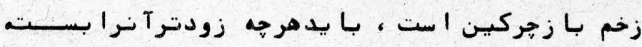

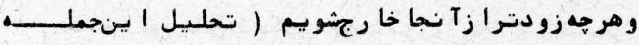

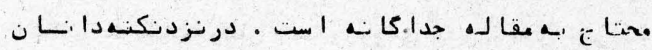

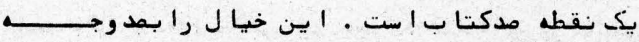

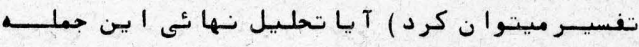

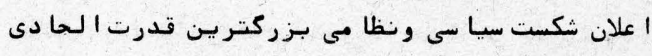

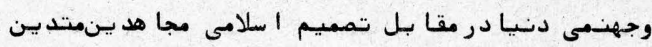
ما نيست Y - حشم همه روشن كمكمونيستها درطول تا ريخ

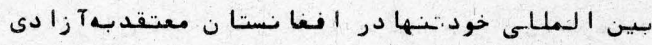

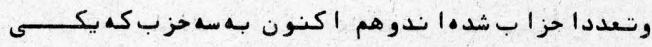

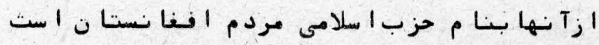

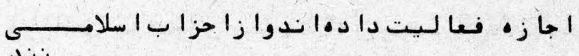

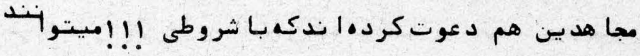

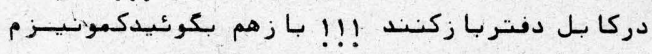

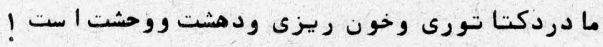

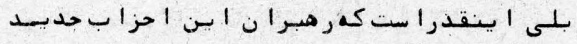

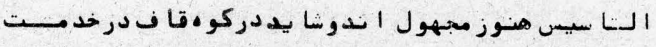

| ستقا مت (r) 


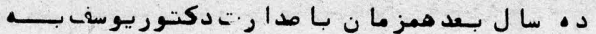

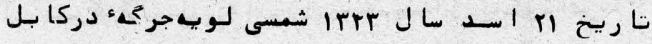

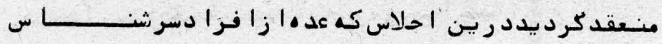

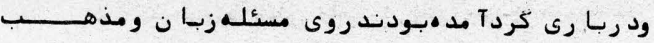

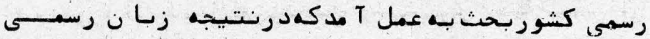

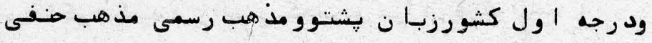

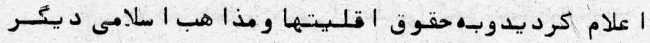

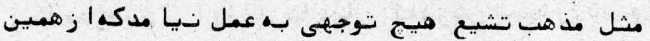

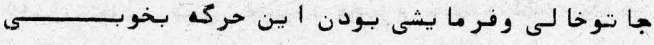

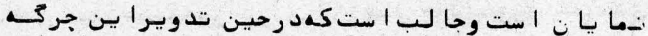

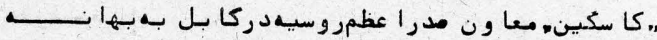

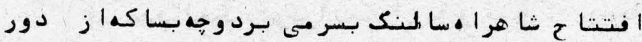

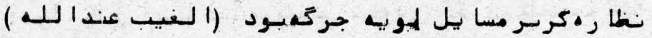

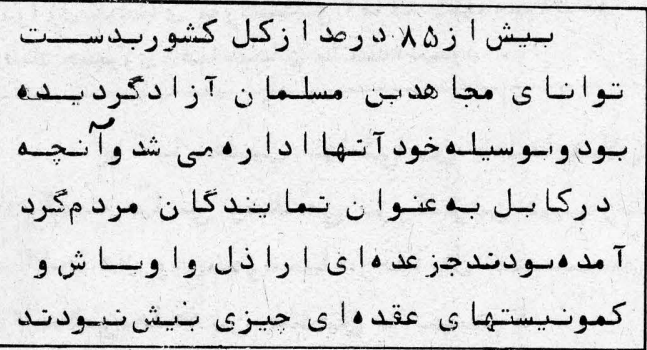

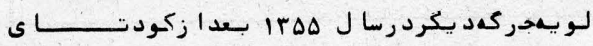

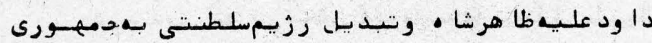

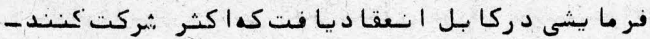

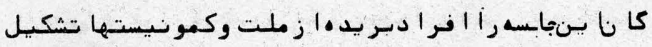

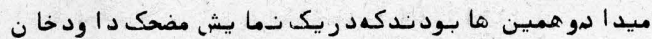

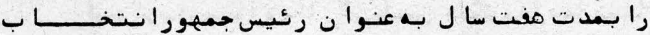

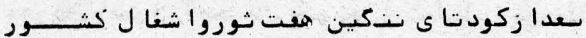

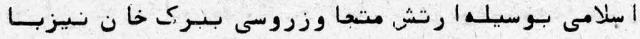

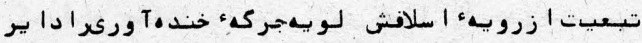

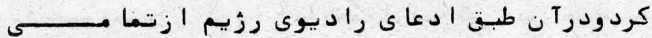

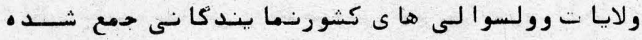

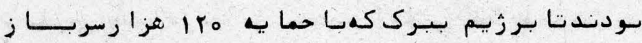

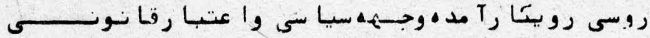

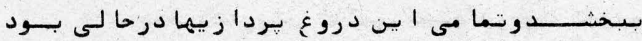

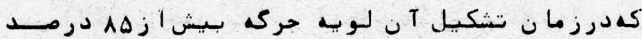

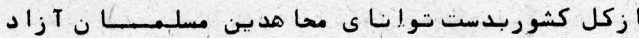

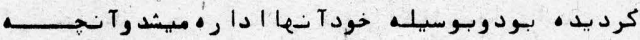

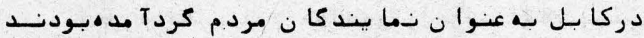

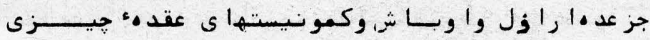

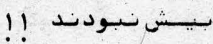

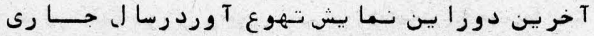

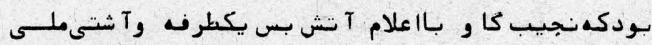

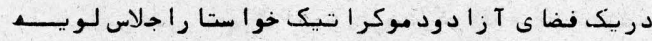

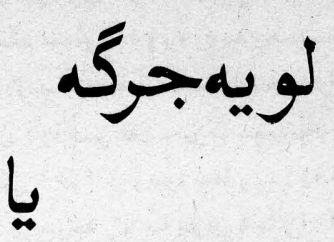

S 5

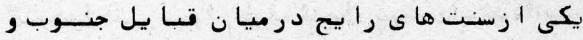

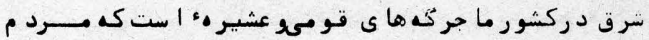

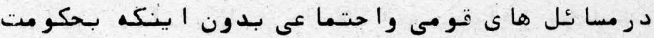

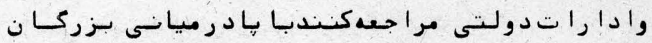

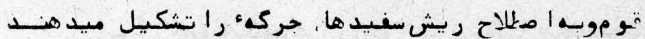

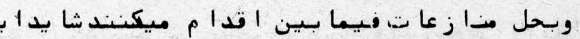

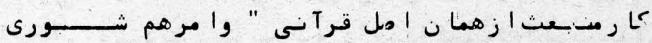

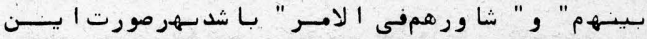

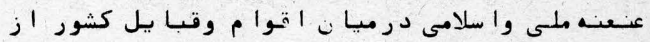

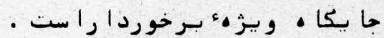

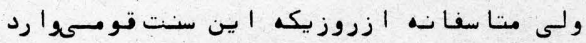

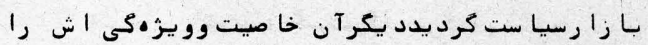

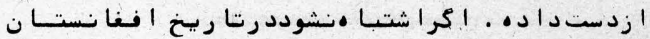

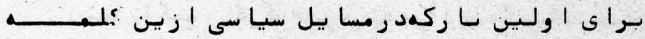

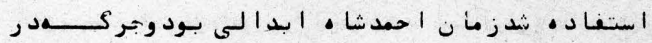
أكتبر IVrV

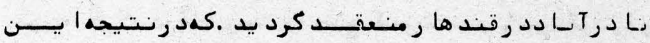

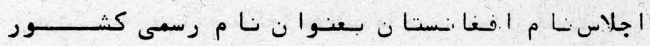

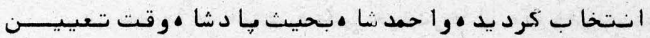

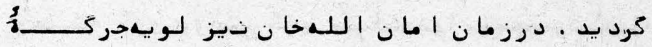

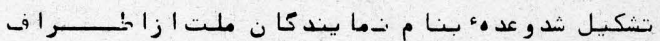

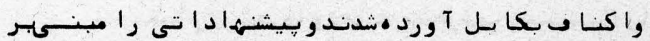

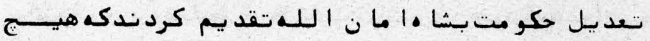

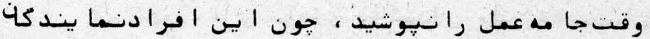

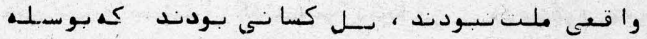

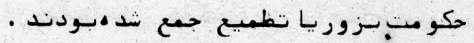

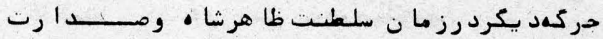

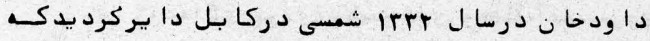

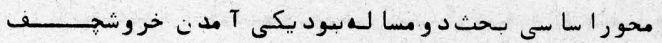

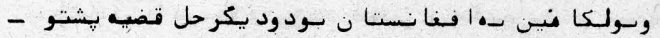

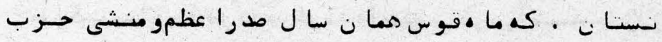

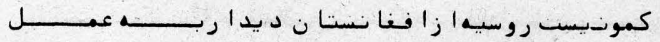

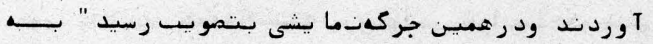

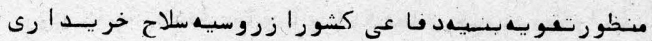




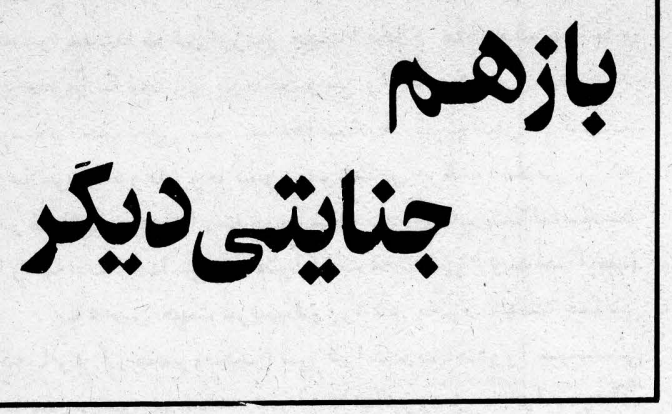

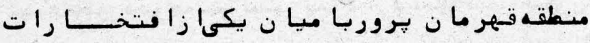

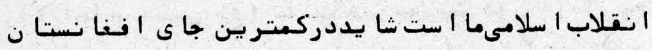

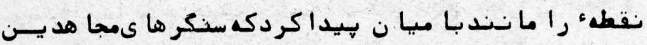

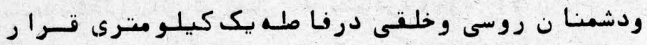

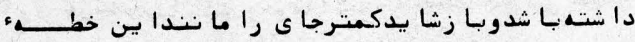

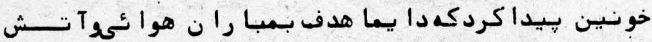

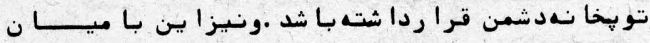

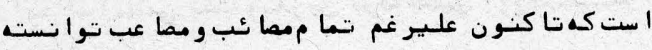

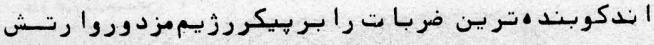

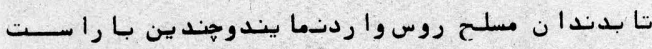

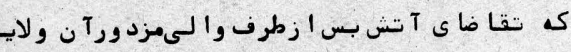

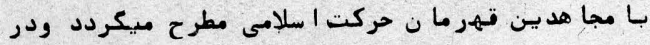

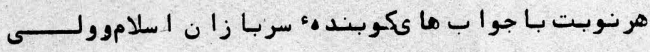

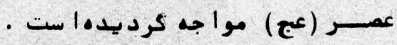

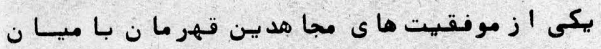

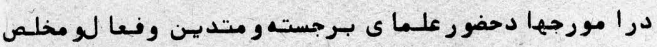

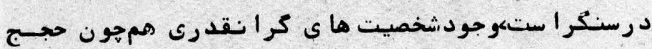

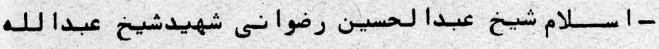

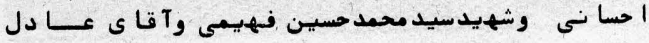

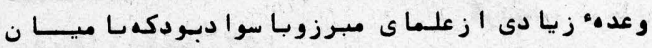

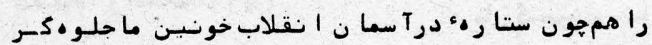

ساخت . را معون

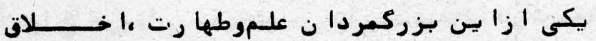

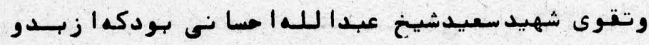

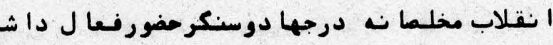

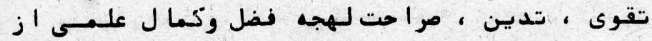

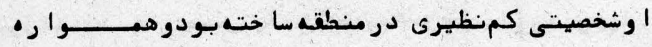

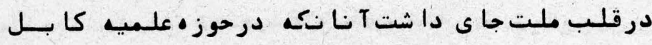

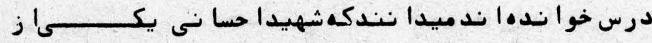

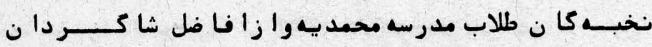

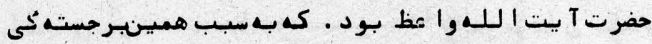

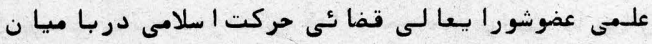

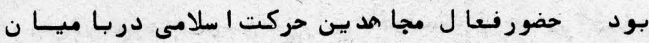

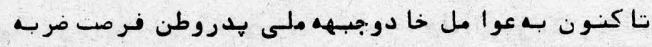

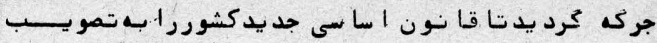

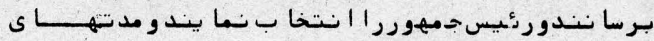

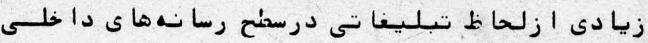

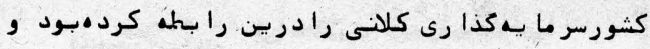

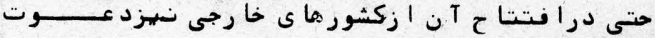

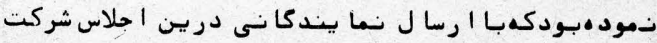

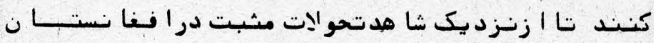
با شند

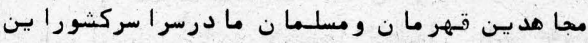

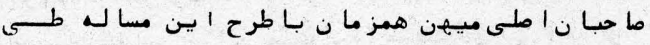

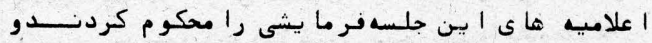

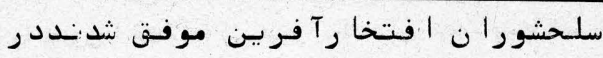

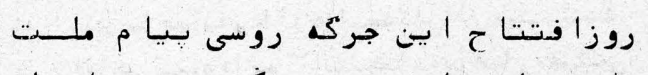

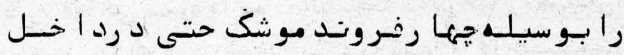

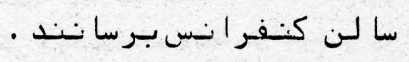

عملا بهـوكر ا ن روسى ا علام نمودندكمتا يك سربسـاز

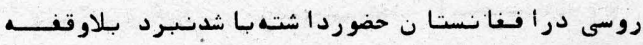

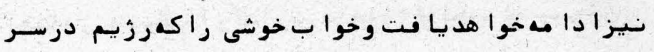

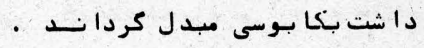

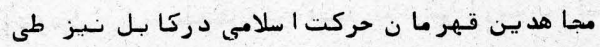

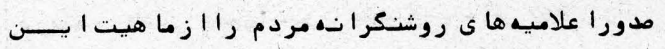

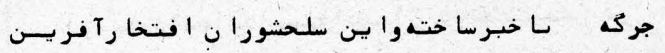

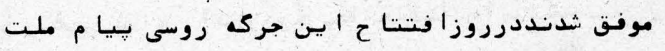

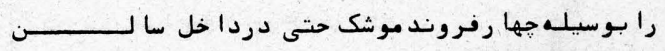

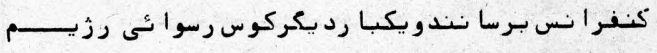

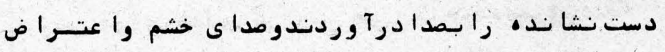

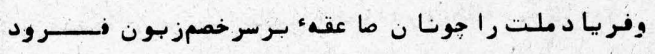

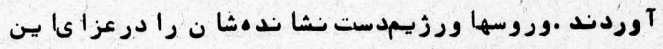

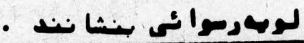

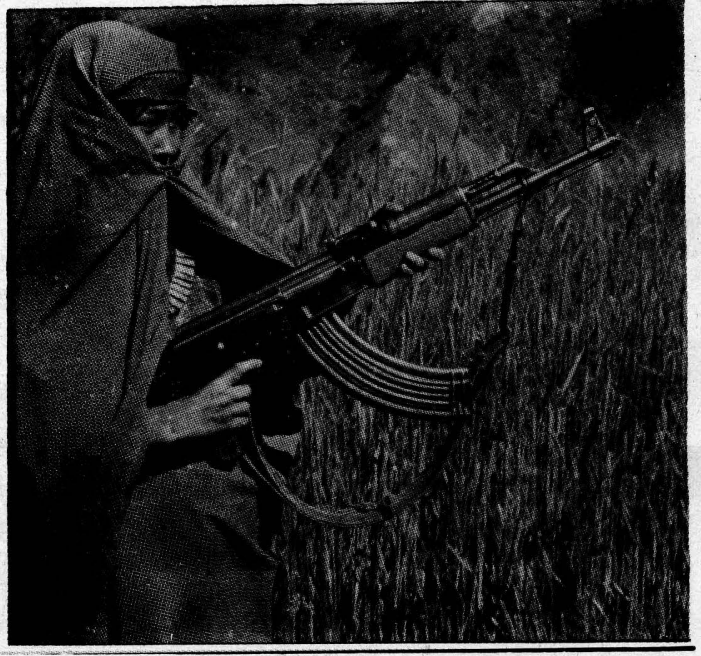




\section{سخنىباخواندكًان}

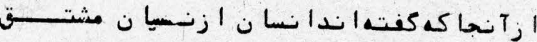

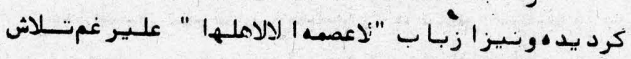

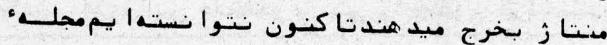

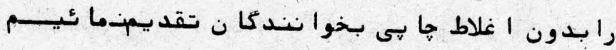

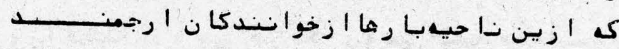

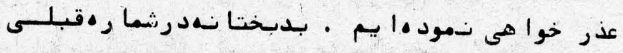

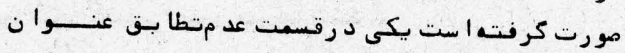

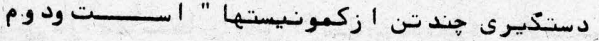

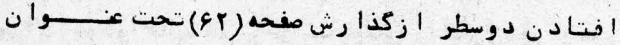

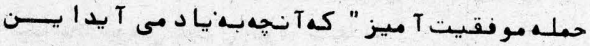

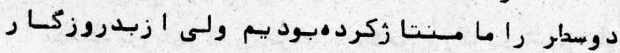

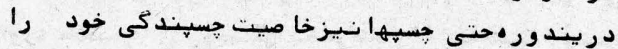

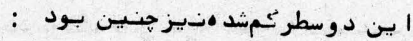

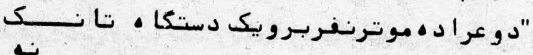

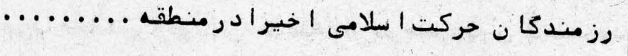

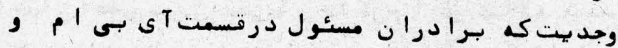

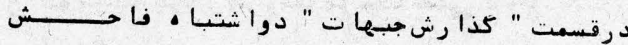

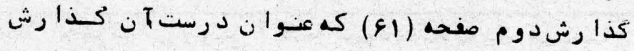

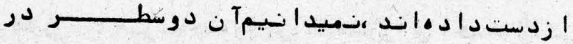

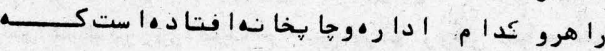

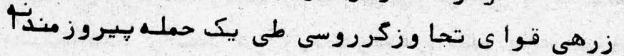

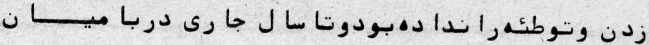

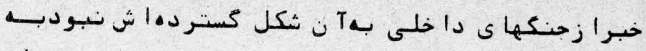

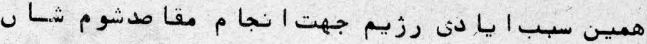

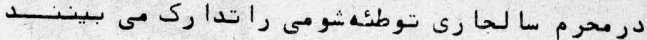

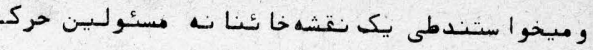

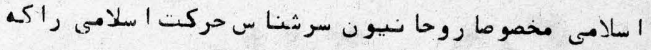

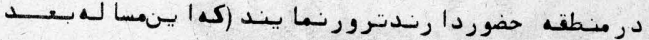

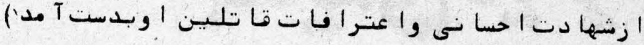

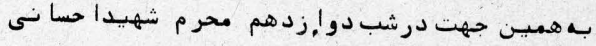

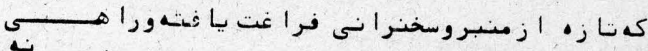

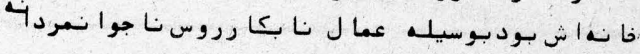

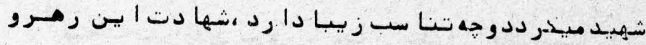

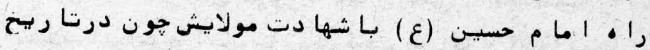

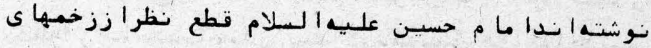

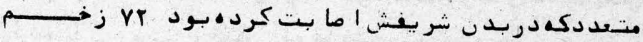

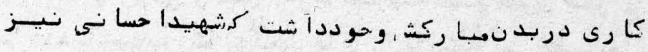

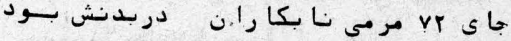

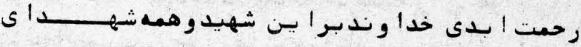

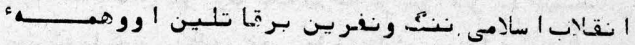

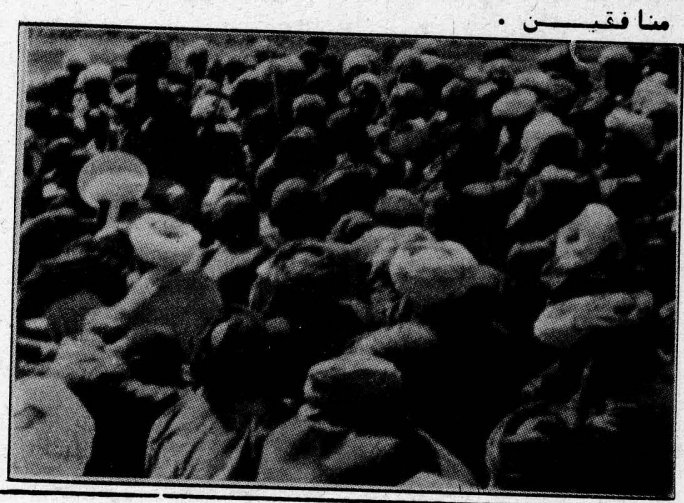

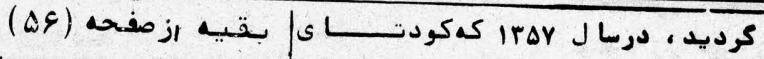

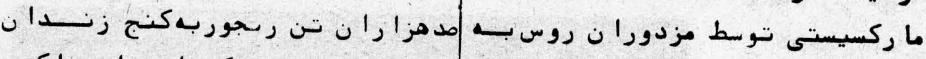

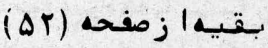

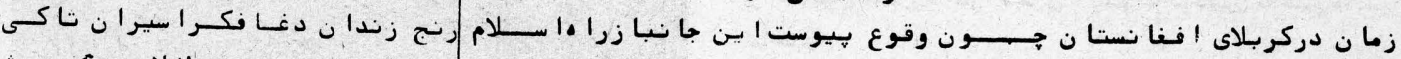

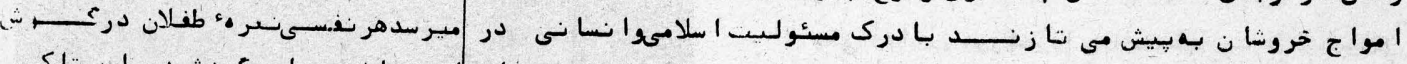

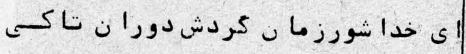

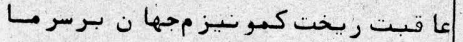

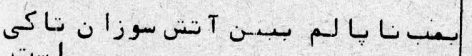

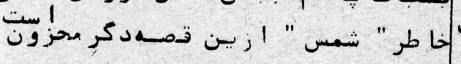

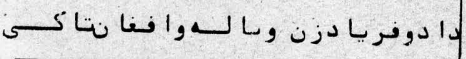

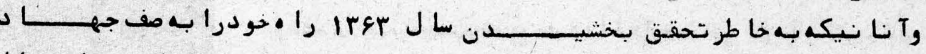

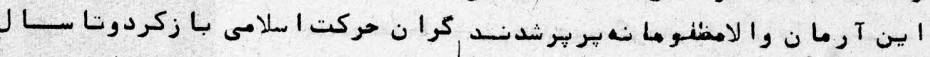

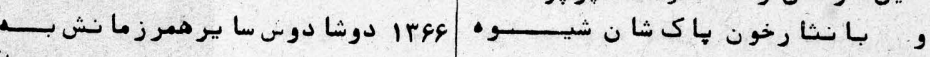

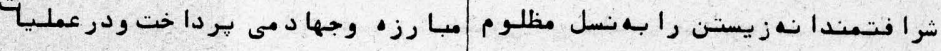

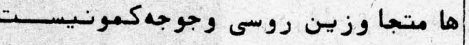

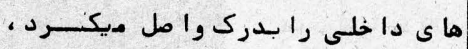

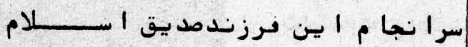

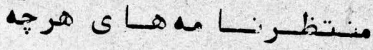

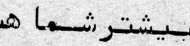

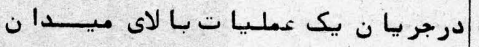

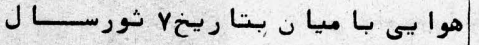

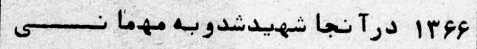

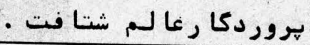

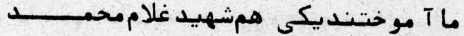

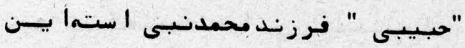

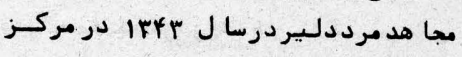

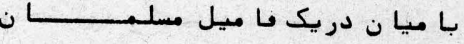
او يس ا زسيرى سمودن دورا ن طفوليت

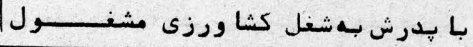

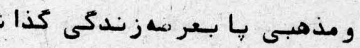




\section{جكونازاززشهاى انقلابمانياسدارينائيم}

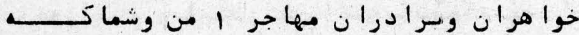

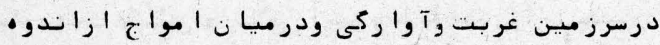

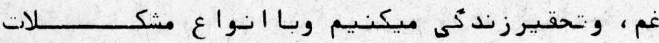

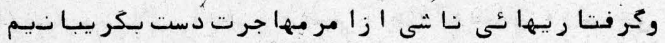

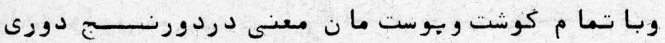

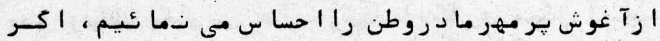

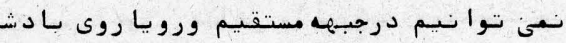

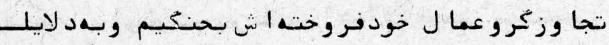

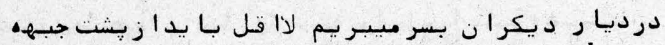

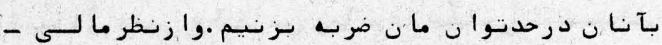

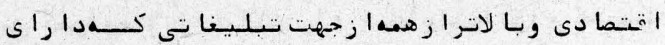

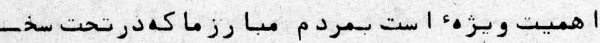

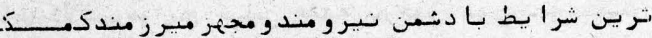

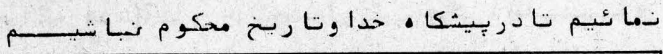

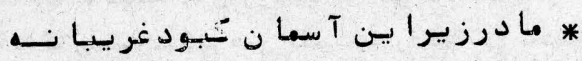

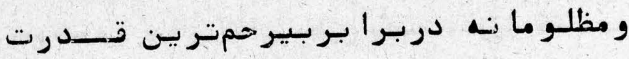

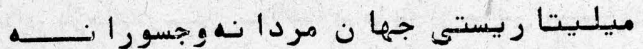

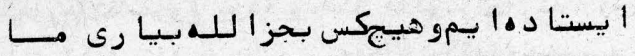

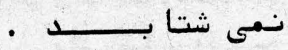

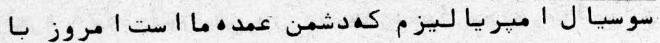

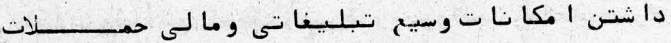

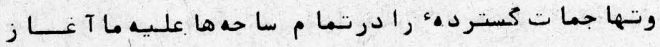

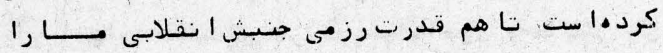

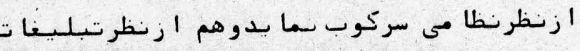

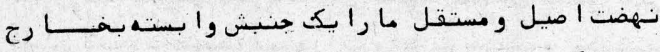

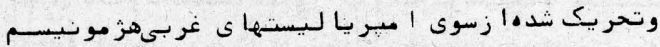

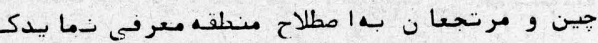

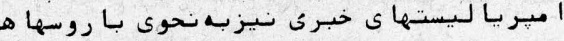

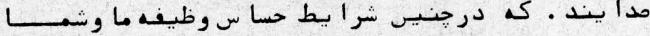

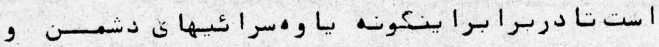

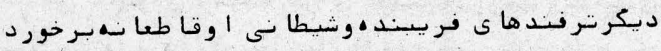

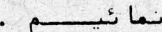

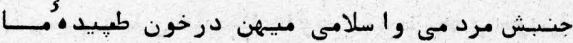

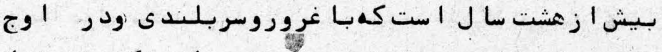

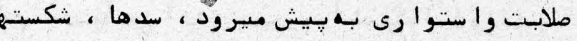

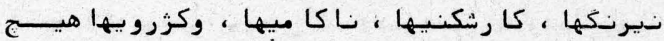

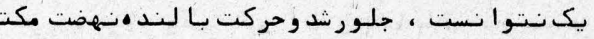

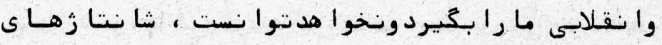

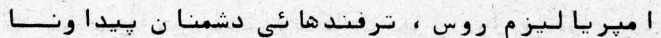

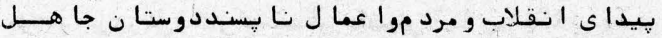

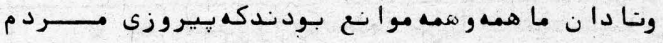

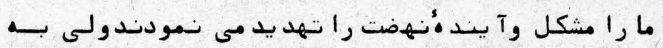

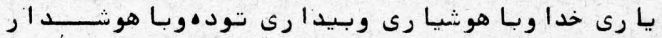

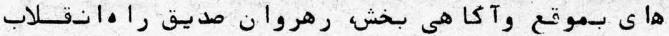

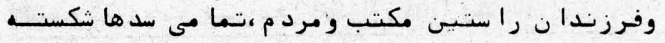

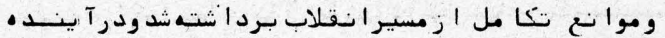

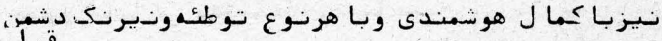

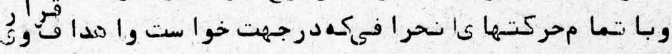

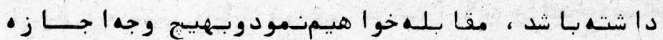

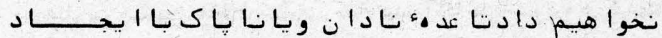

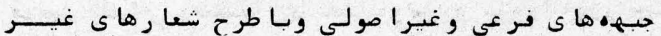

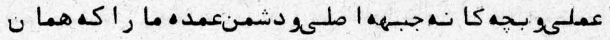

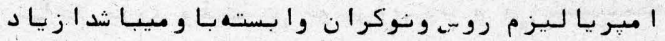

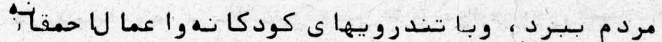

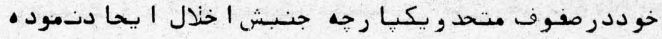

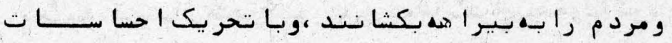

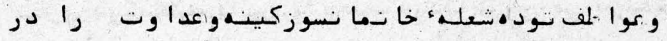

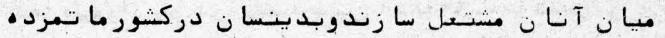

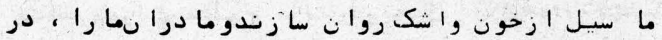

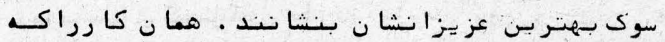

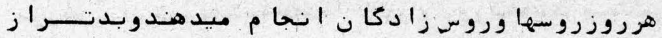

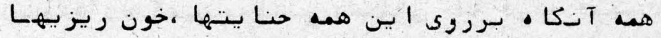

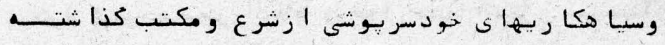

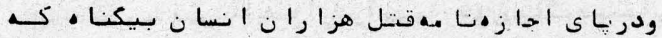

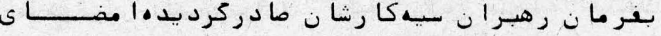

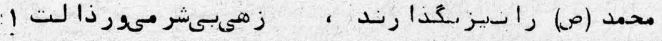


ضرورى ا ستـ ولى اكركـس وويا كسا نى بدست آ وردنتـدر

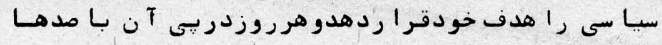

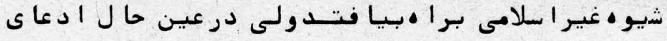

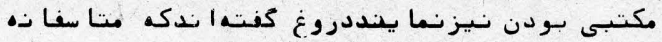

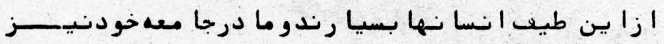

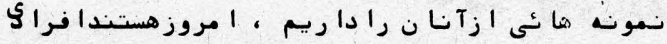

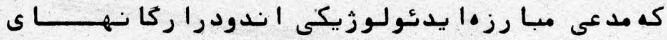

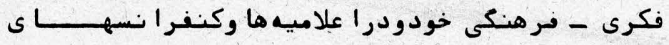

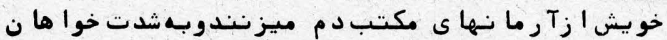

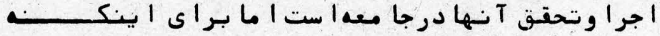

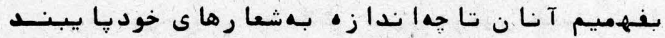

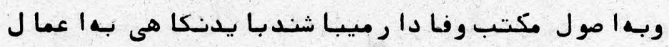

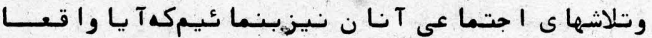

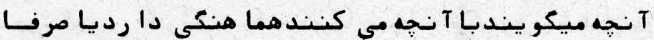

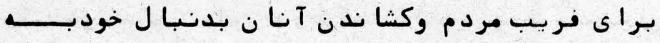

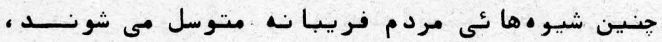

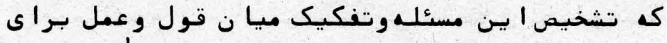

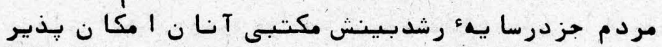

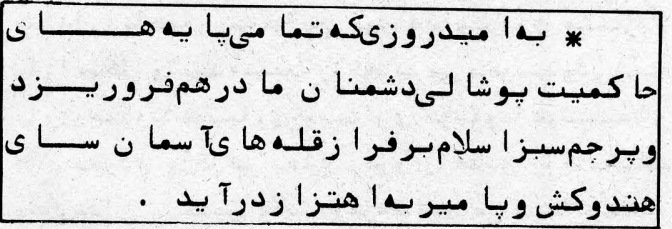

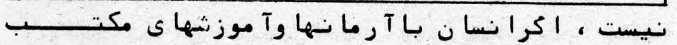

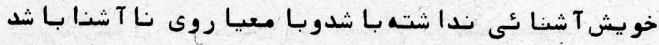

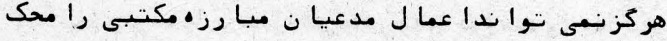

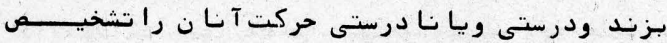

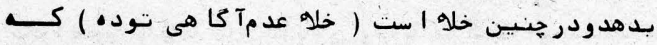

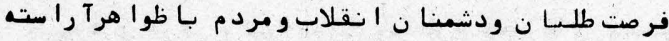

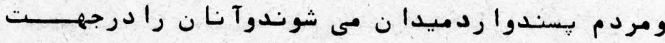

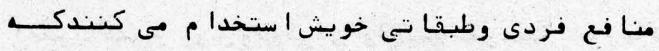

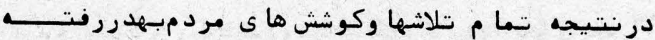

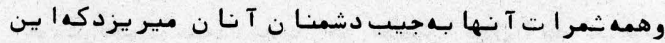

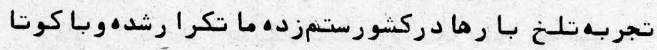

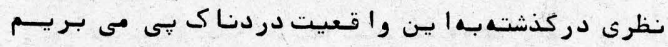

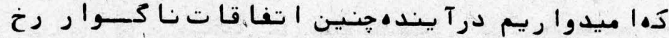

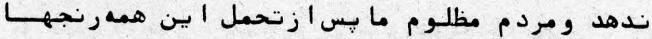

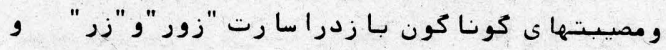

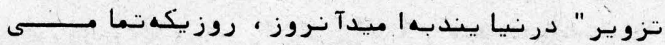

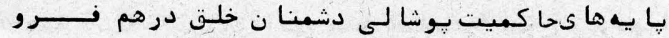

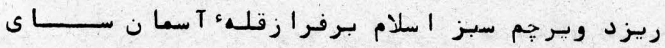

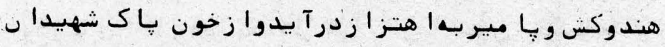

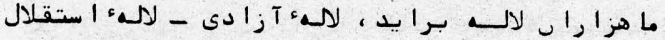

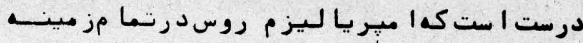

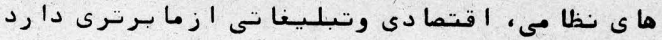

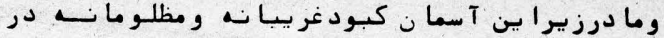

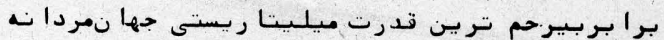

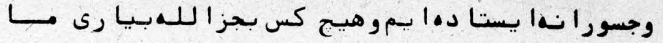

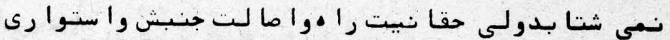

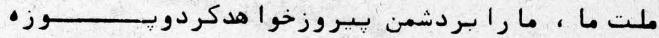

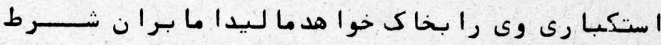

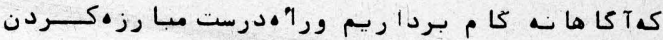

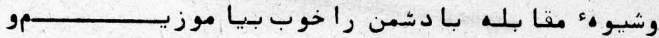

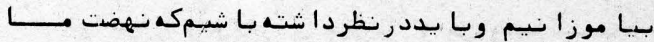

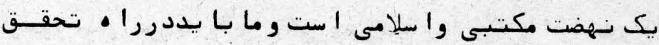

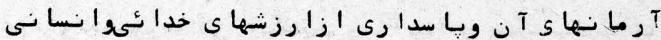

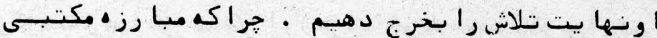

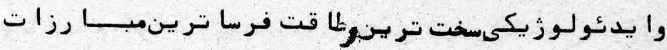

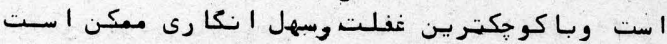

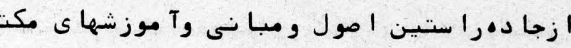

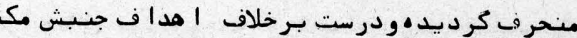

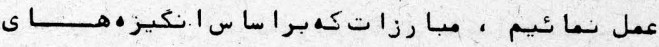

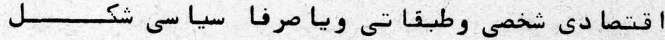

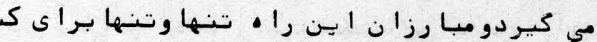

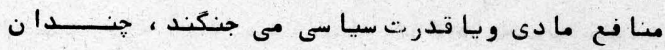

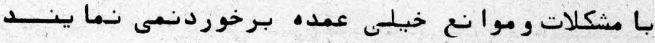

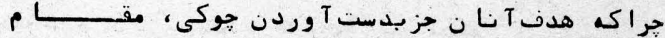

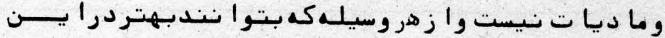

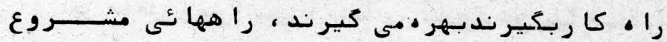

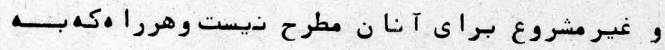

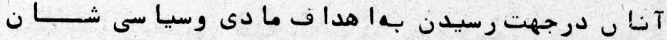

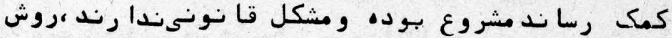

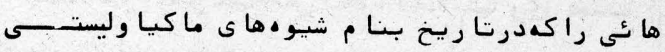

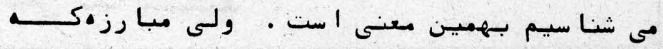

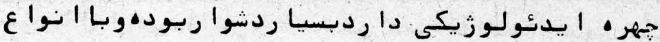

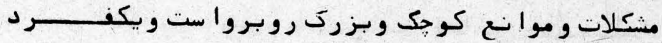

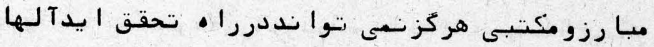

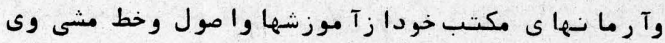

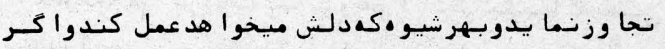

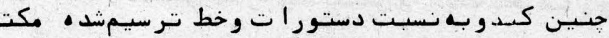

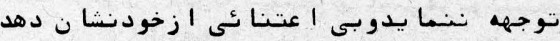

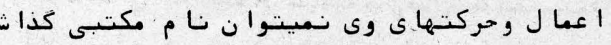

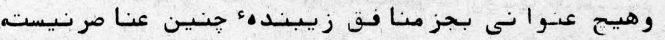

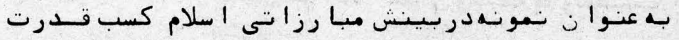

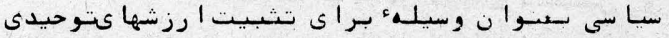

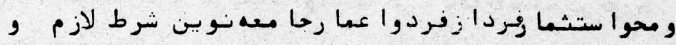




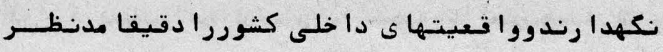

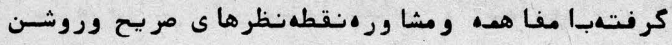

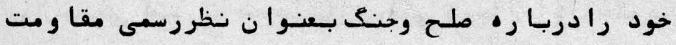

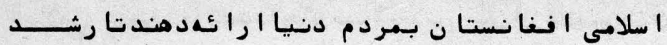

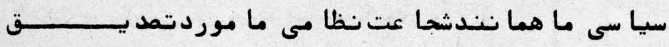

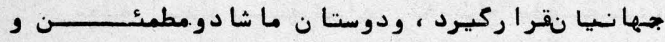

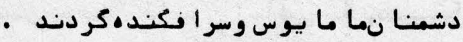

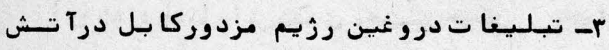

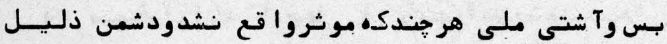

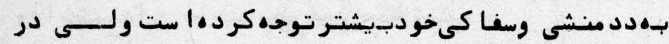

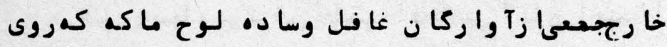

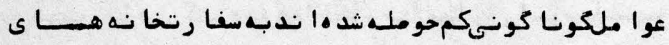

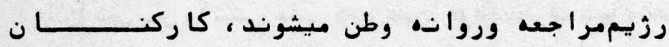

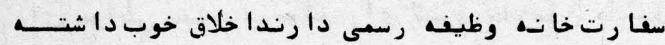

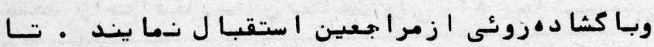

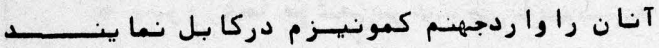

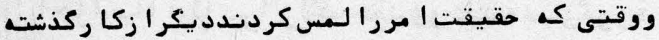

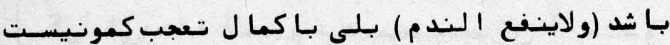

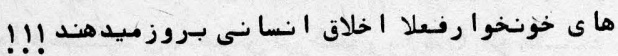

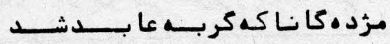

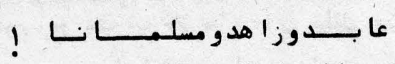

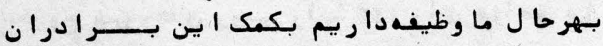

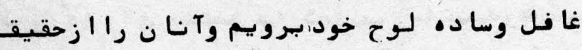

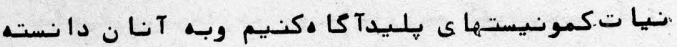

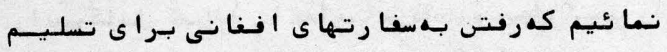

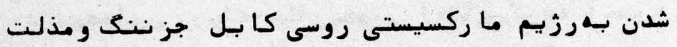

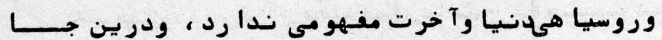

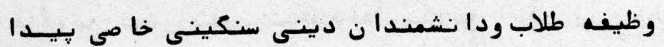
ميكند وطند

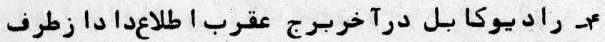

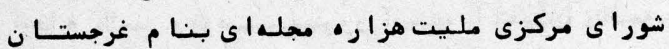

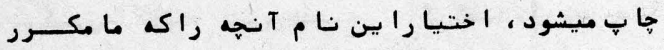

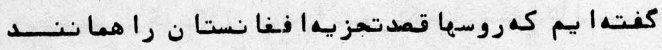

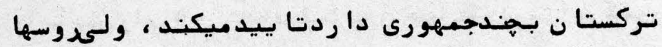

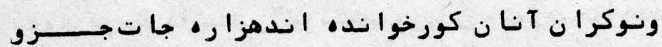

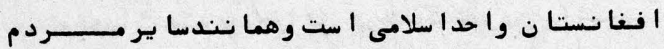

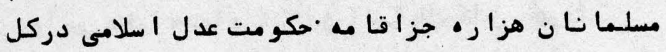

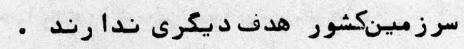

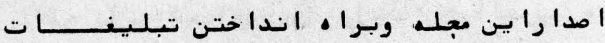

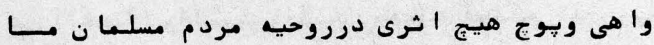

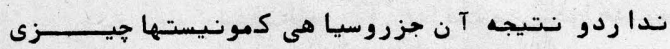

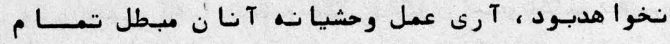

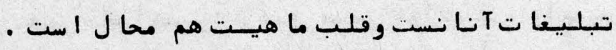

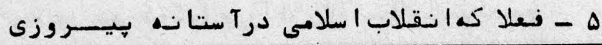

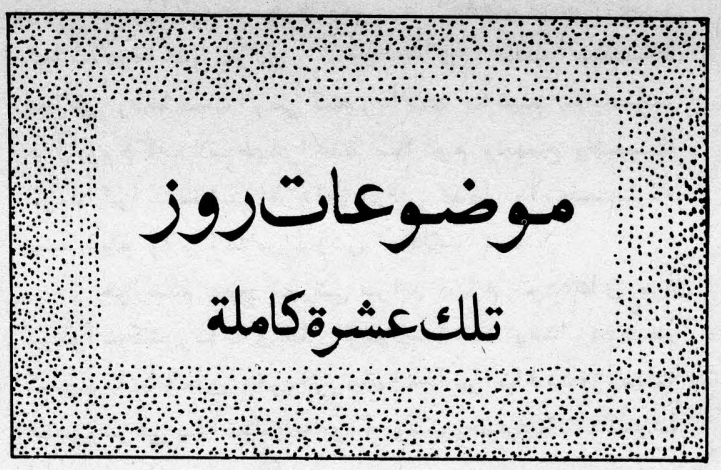

|- درشرا يط فسلسى كه حومله روسها ا زدس

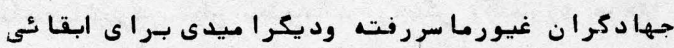

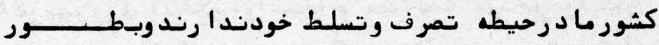

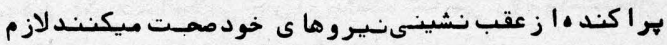

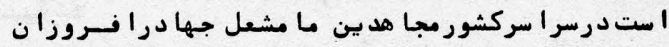

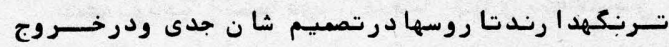
خودسر يعترشوند

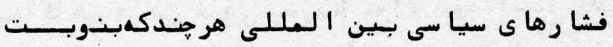

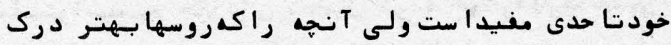

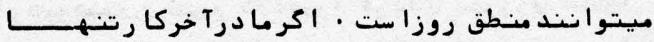

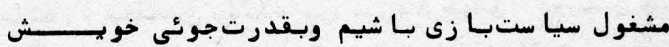

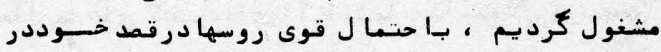

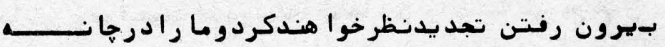

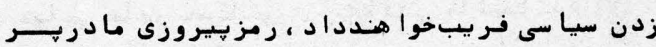

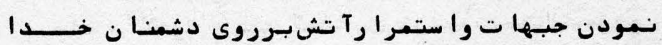

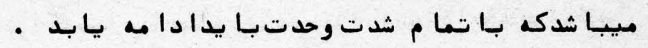

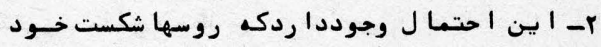

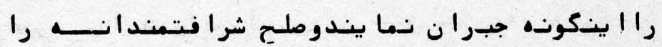

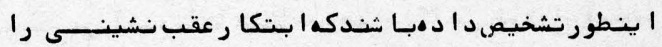

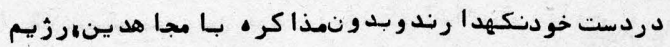

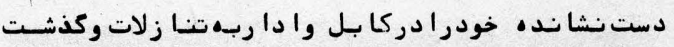

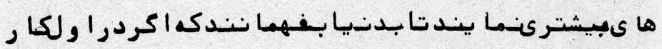

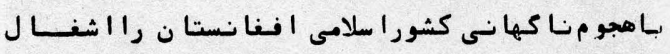

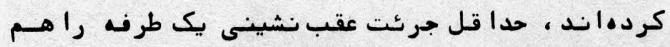

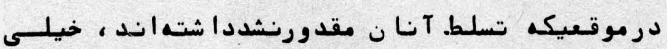

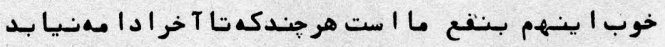

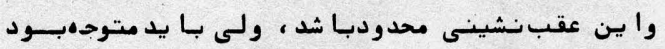

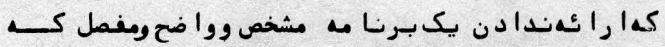

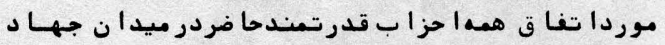

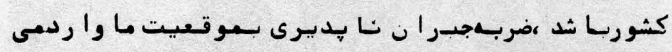

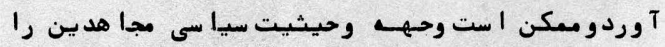

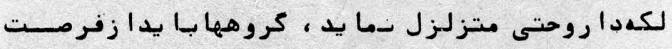

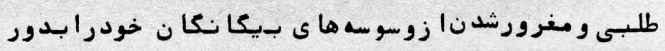

ستقا مت (9) 
1- ما أكربخوا هيه هِيروزى النقلاب خودرا تضمين

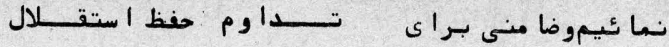

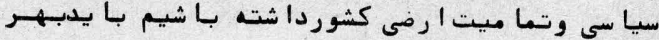

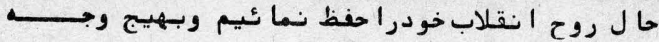

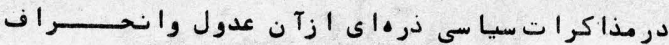

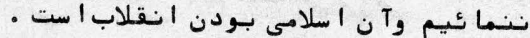

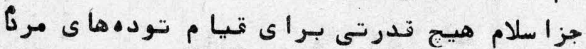

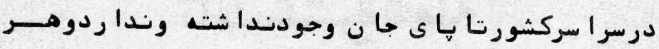

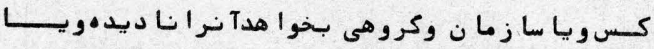

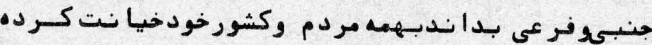

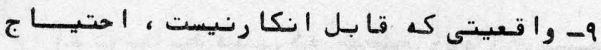

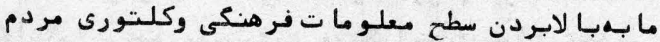

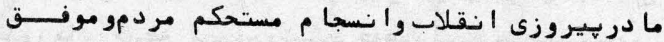

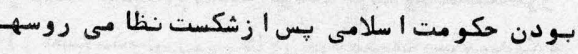
ميبا شه

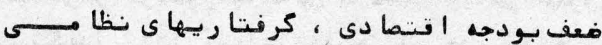

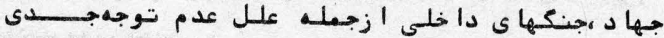

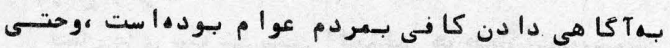

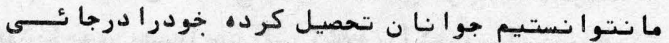

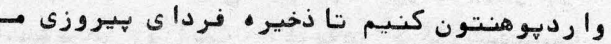

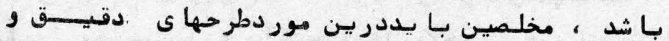

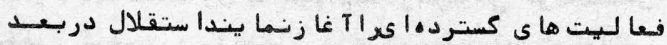

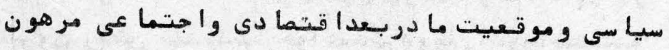

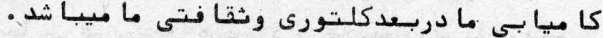

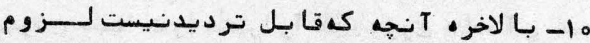

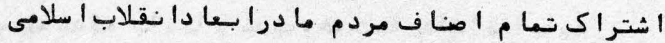

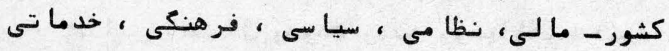

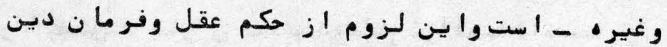

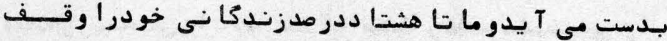

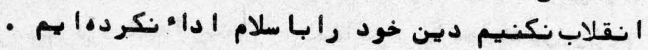

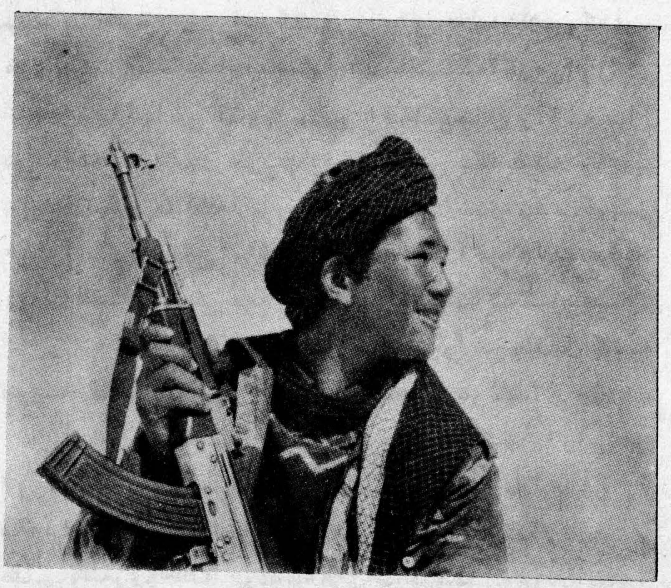

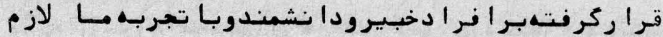

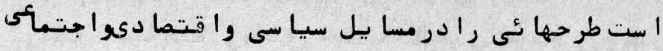

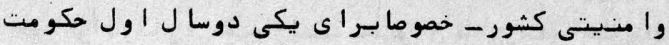

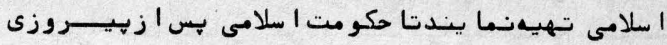

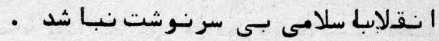

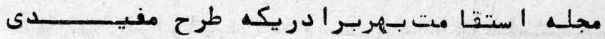

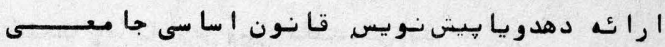

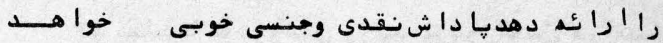

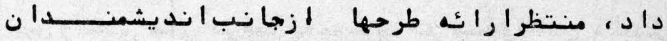

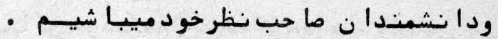

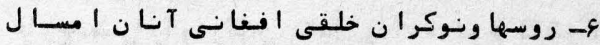

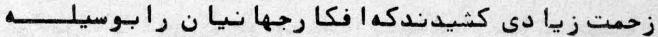

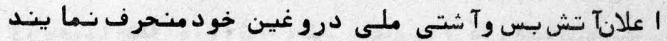

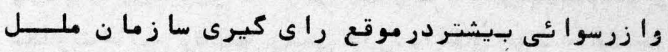

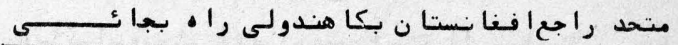

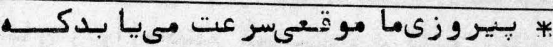

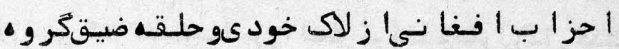

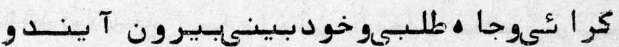

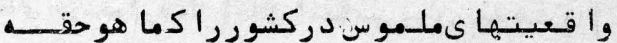

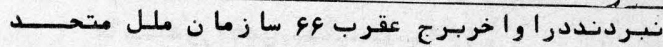

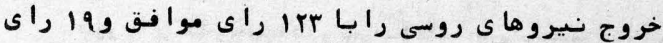

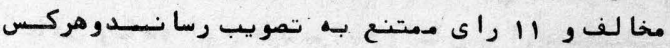

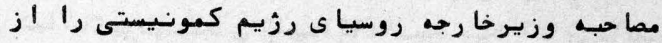

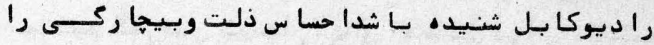

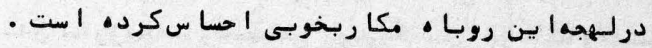

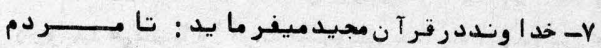

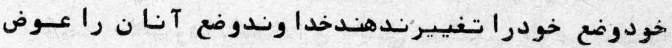

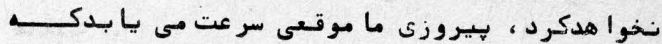

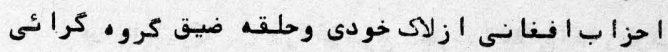

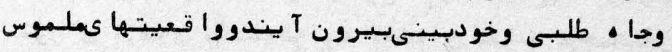

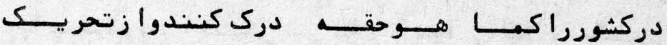

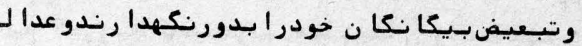

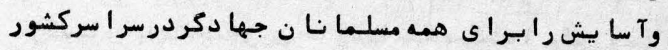

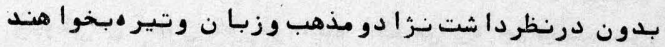

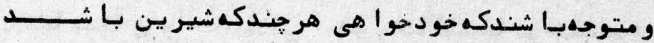

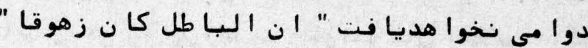

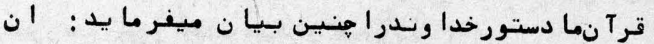

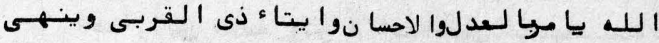

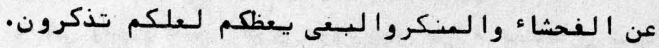

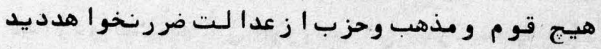

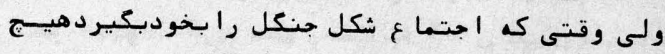

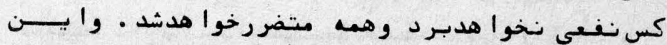

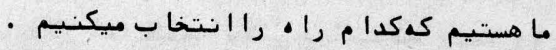




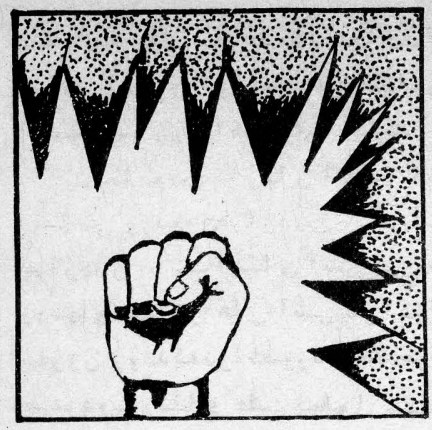

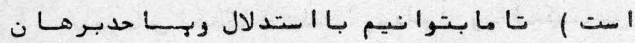

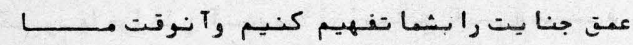

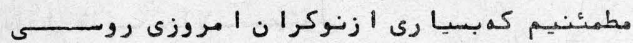

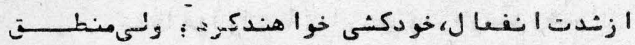

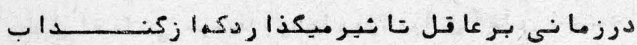

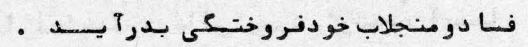

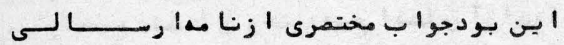

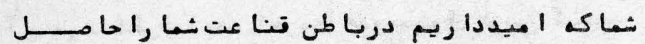

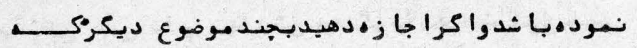

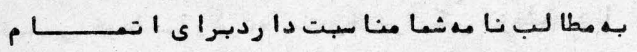

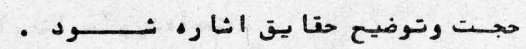

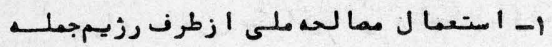

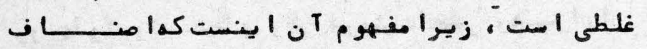

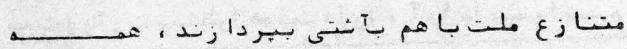

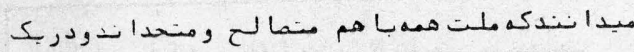

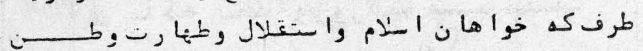

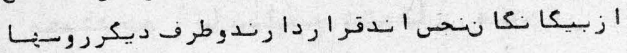

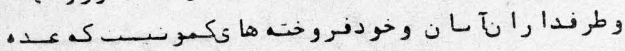

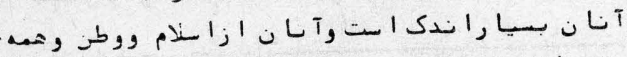

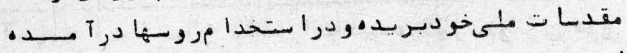

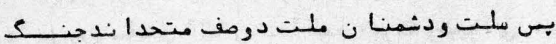

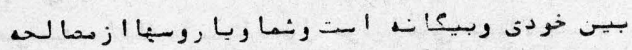

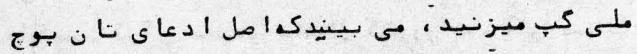

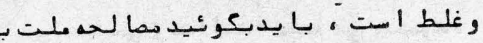

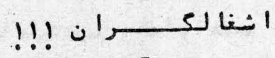

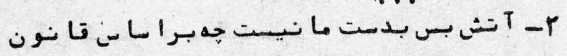

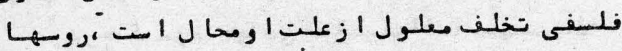

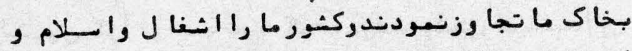

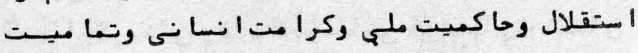

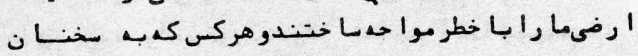

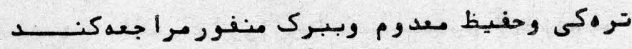

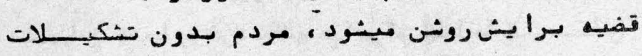

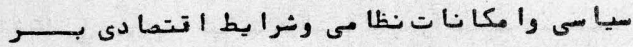

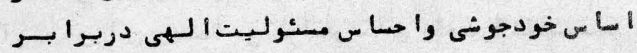

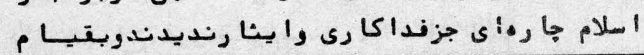

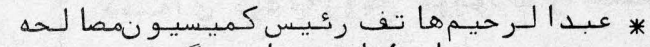

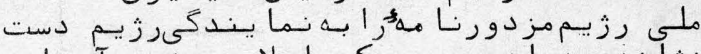

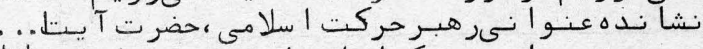

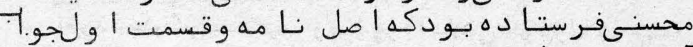

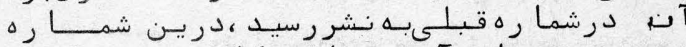

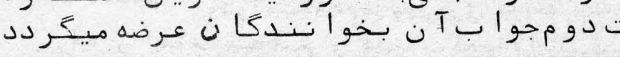

Fا

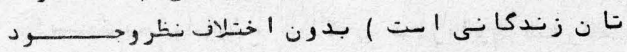

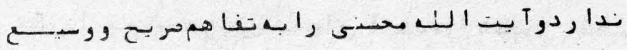

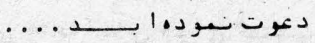

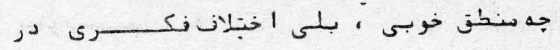

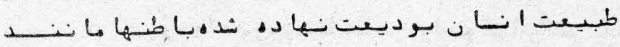
ج بـ

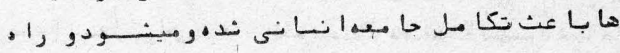

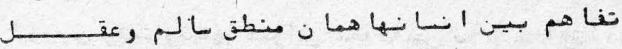

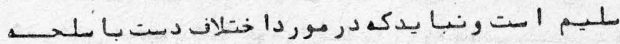

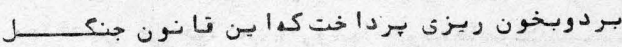

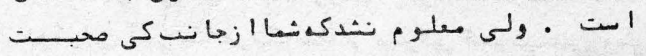

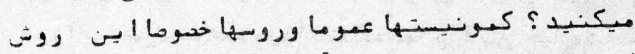

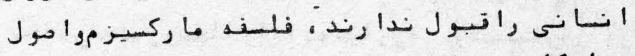

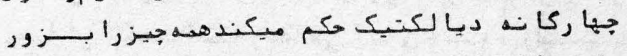

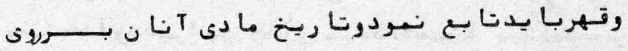

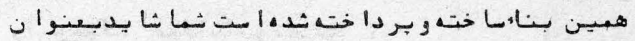

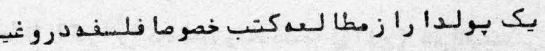

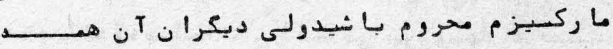

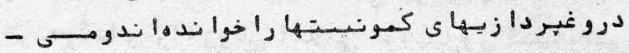

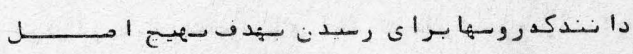

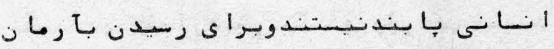

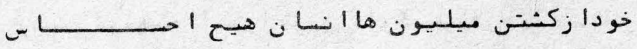

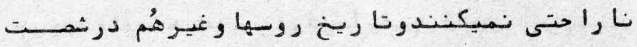

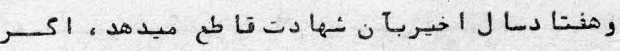

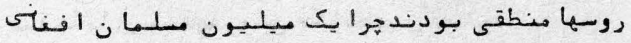

شما ا كرطا لـب صحبـت

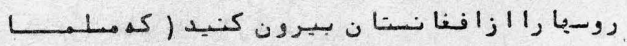

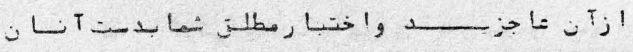




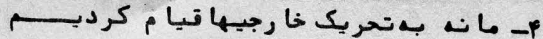

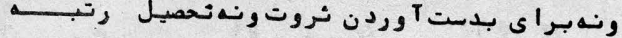

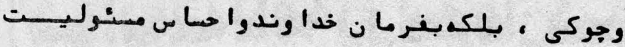

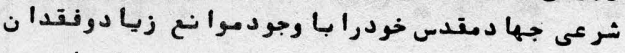

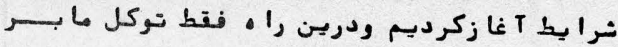

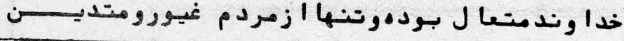

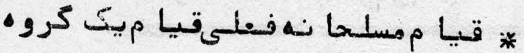

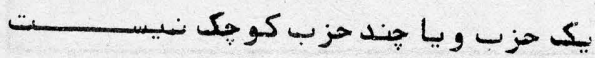

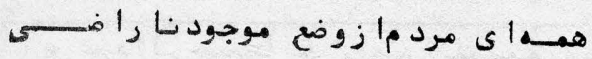

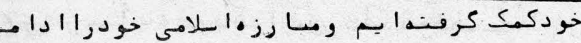

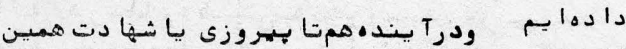

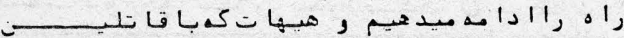

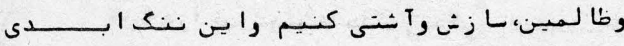

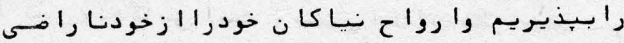

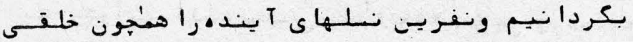

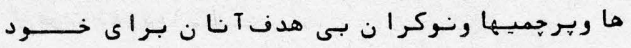
بخريس

- روسها ديروزمجا هدين را نوكرا نآ مريكا

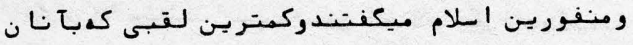

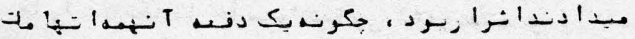

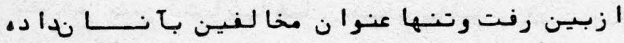

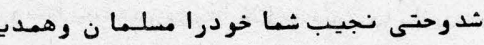

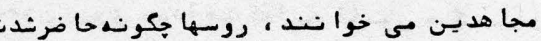

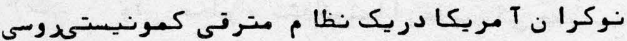

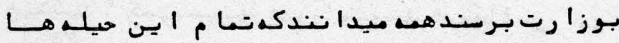

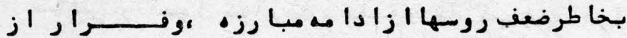

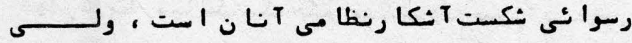

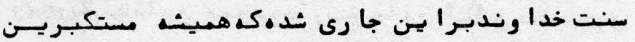

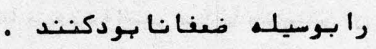

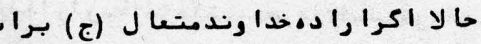

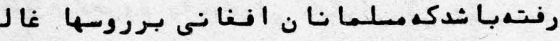

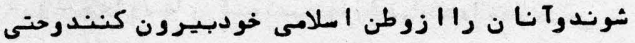

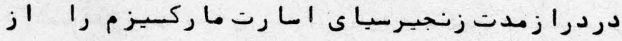

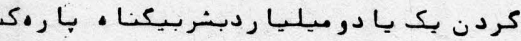

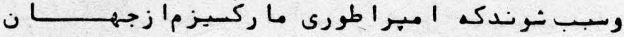

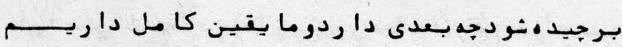

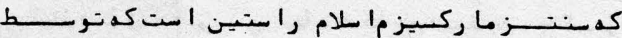

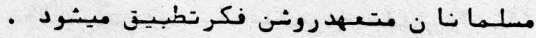

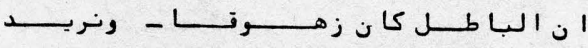

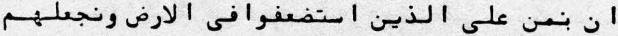

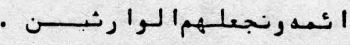

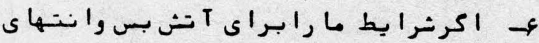

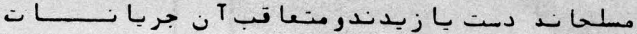

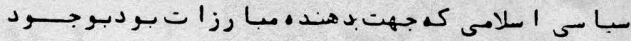

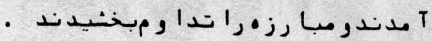

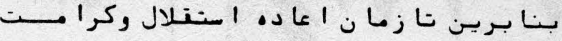

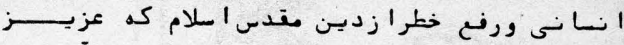

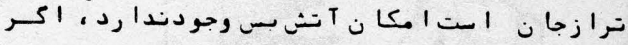

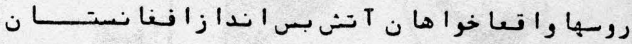

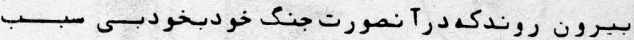

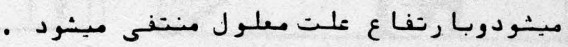

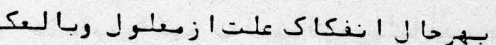

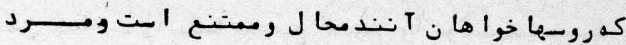

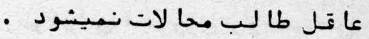

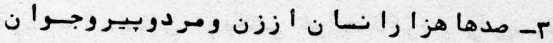

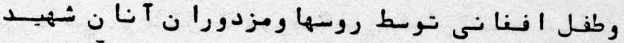

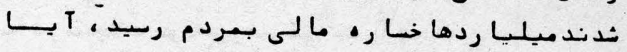

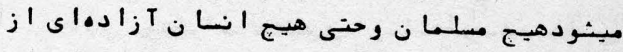

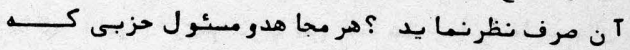

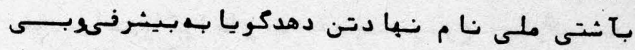

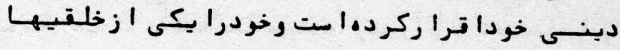

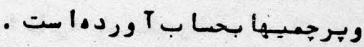

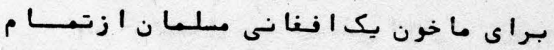

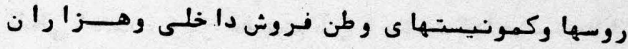

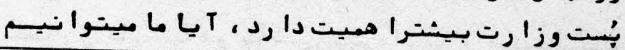

* ما كه بخدا وروزقيا مـــ

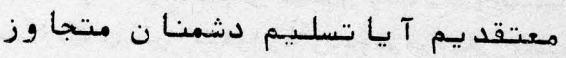

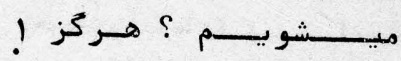

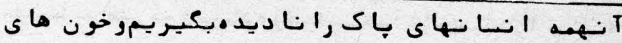

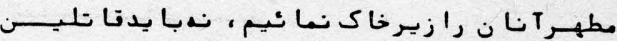

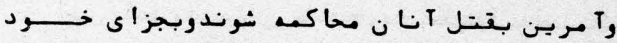

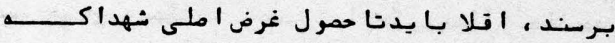

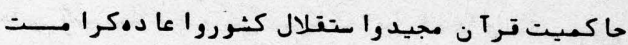

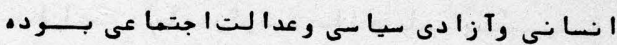

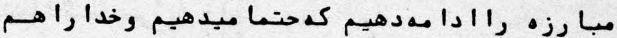

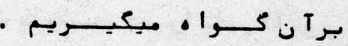

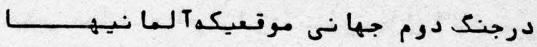

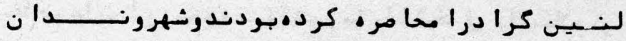

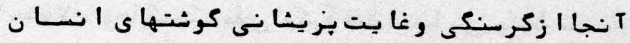

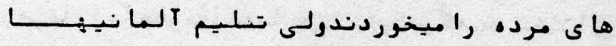

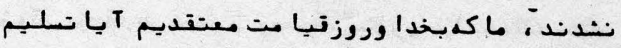

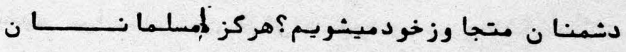

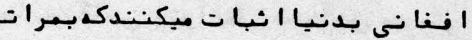

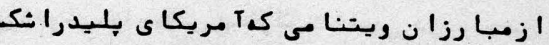

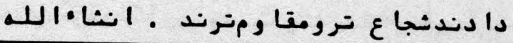




\section{جاهليتمدرن}

هروا ضح ا ست كه عصرحا ضردر مقا يسه با ا عمـــــا ر

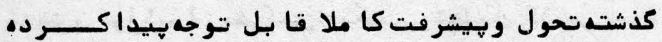

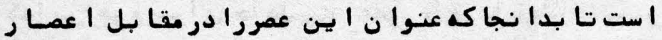

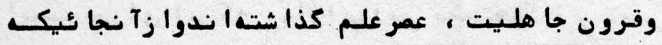

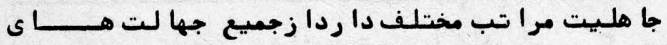

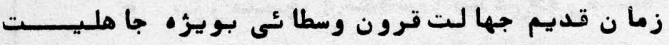

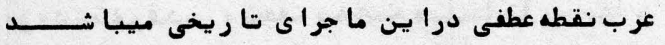

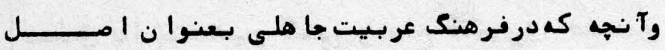

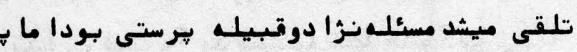

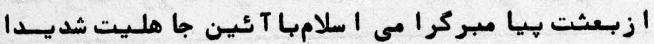

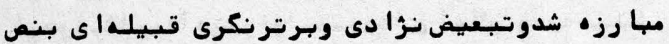

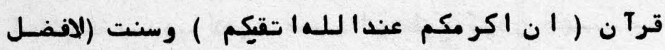

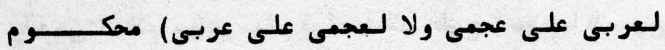

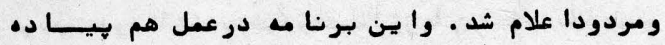

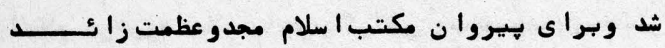

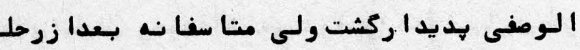

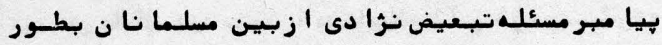

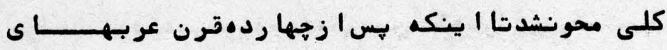

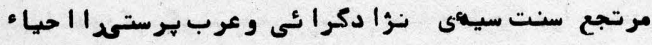

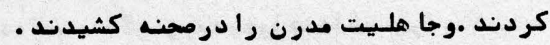

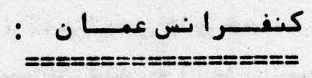

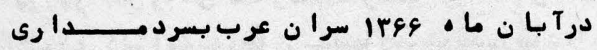

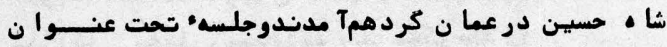

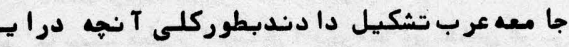

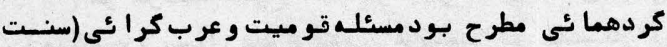

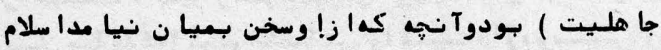

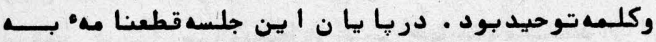

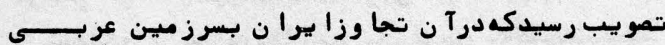

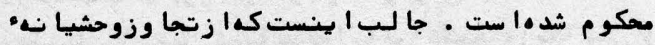

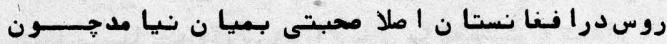

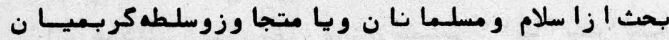

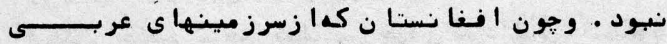

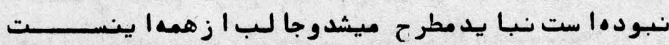

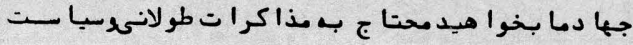

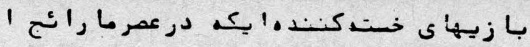

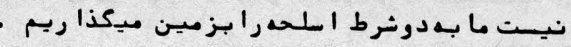

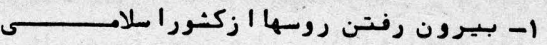

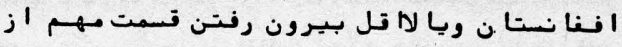

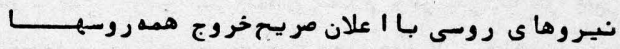

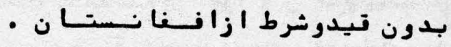

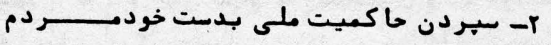

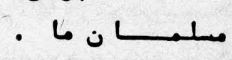

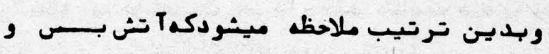

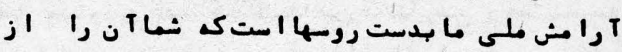

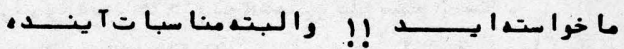

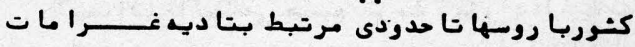

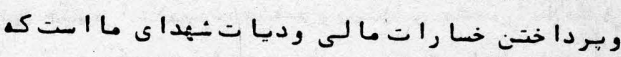

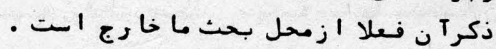

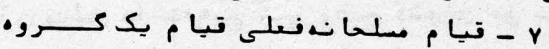

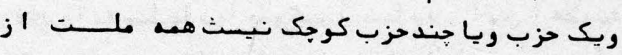

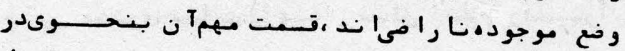

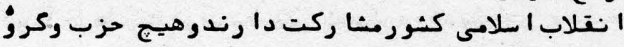

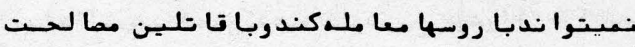

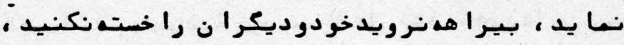

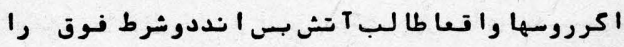

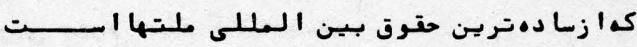

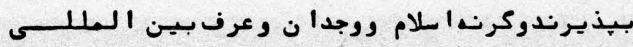

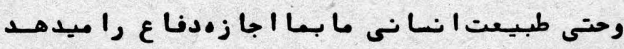

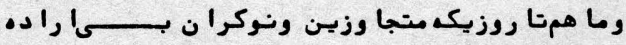

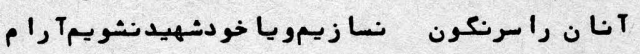
نمي نشينيم.

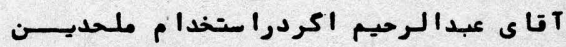

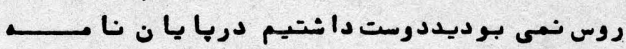

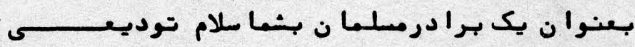

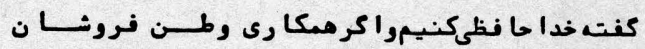

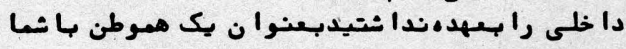

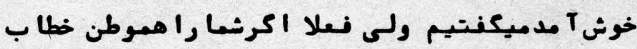

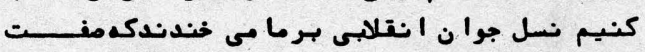

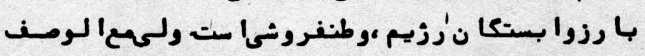

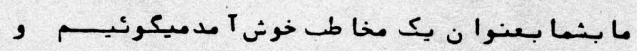

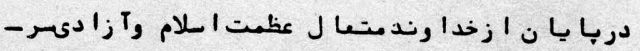

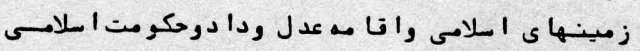

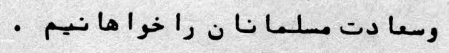

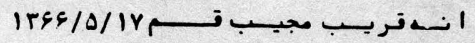

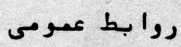

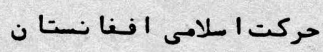




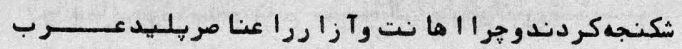

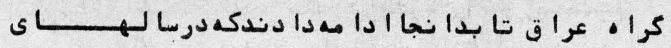

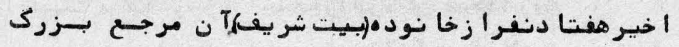

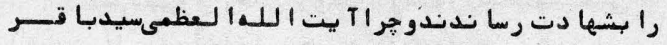

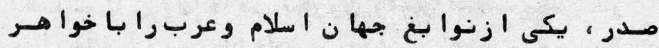

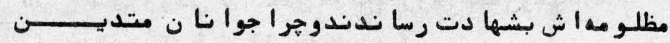

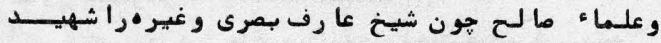

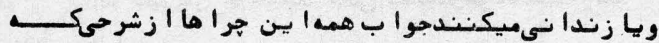

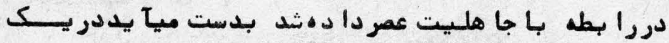

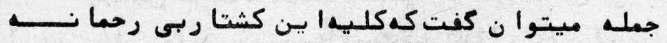

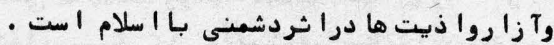

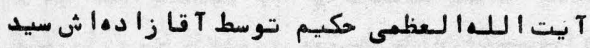

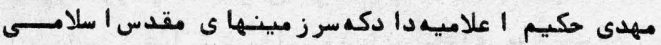

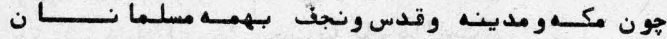

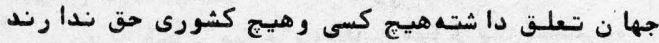

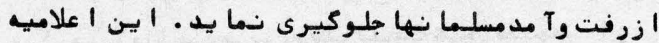

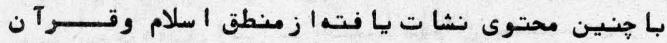

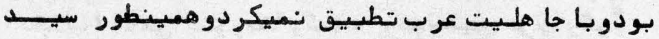

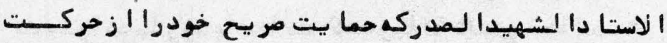

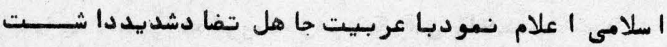

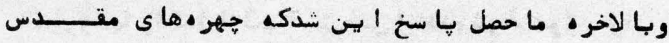

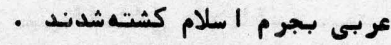

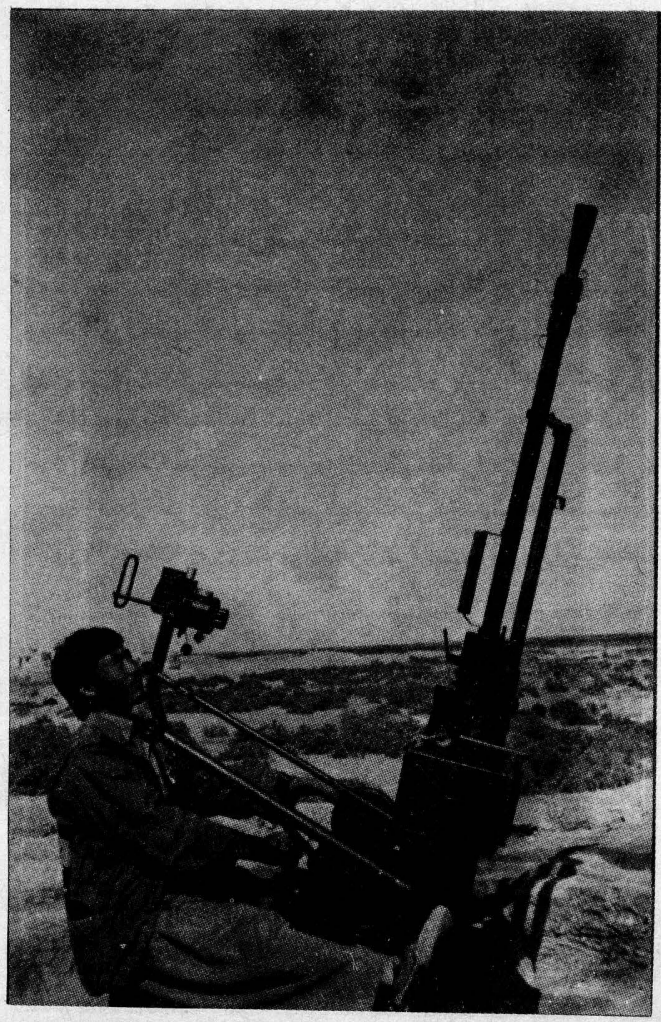

كمازا شغال سرزمين هاى اعراب توسط اسرأئيـــلـل

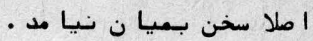

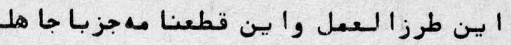

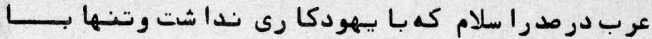

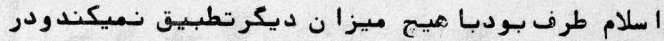

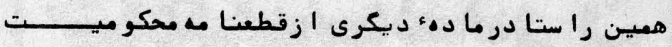

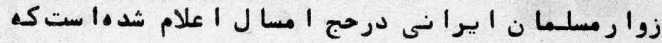

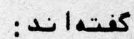

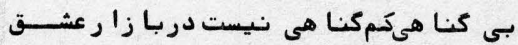

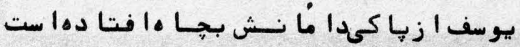

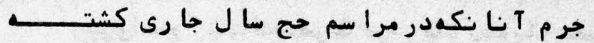

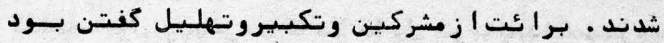

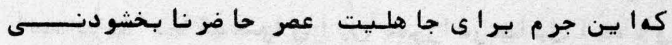

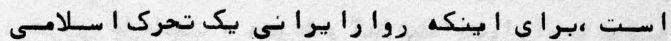

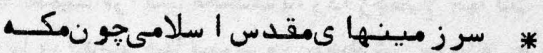

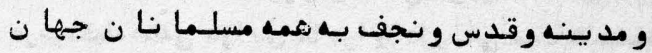

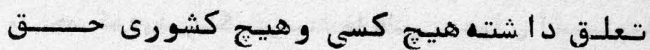

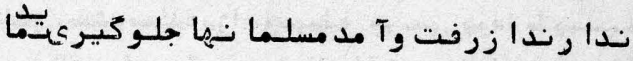

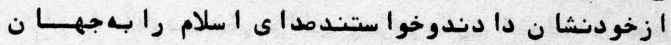

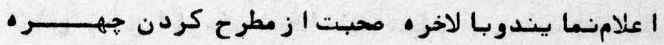

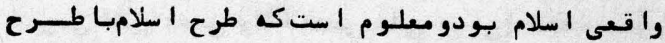

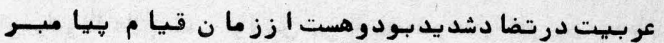

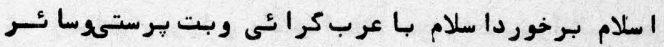

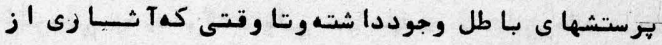

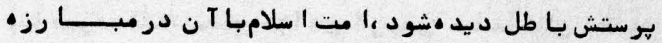

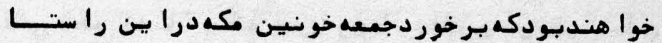

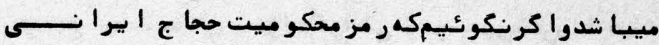

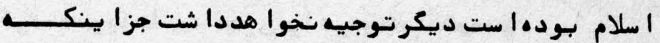

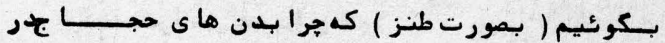

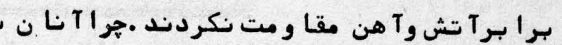

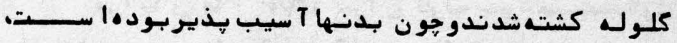

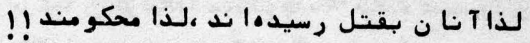

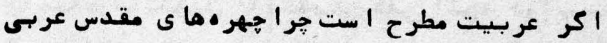

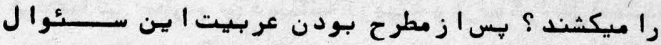

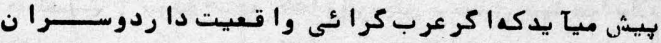

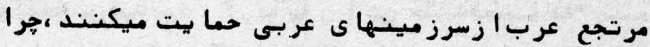

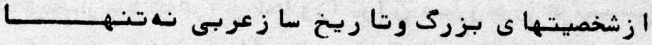

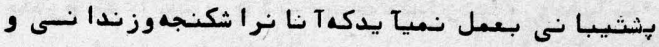

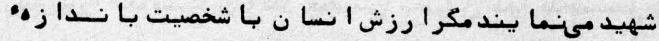

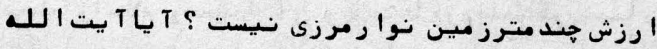

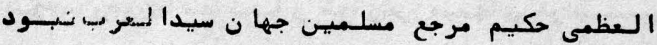

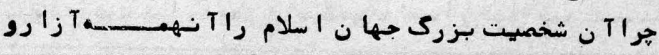




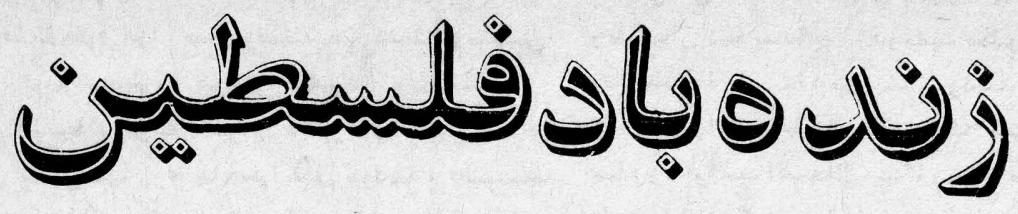

ا مروز فلسطين قلب خونسين ا سلام است كها زآنهر

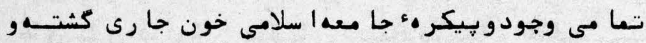

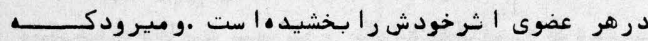

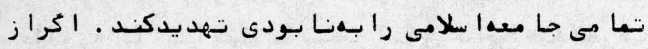

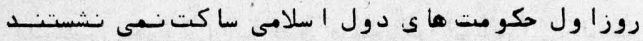

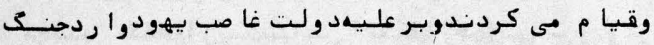

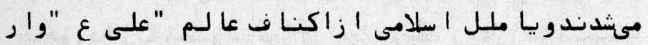

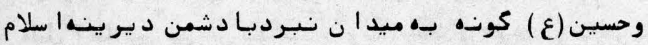

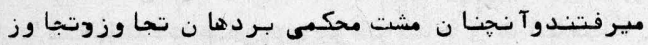

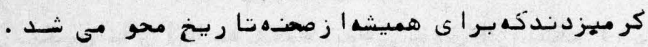

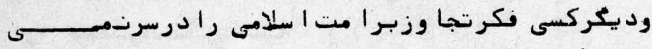

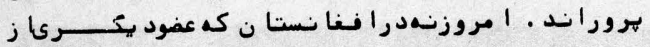

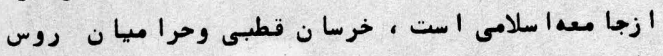

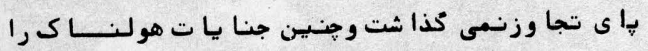

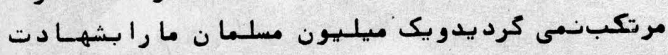

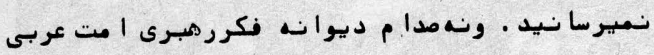

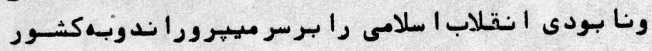

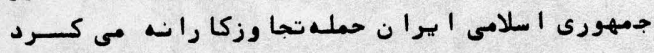

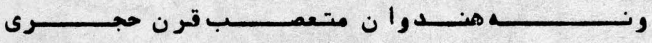

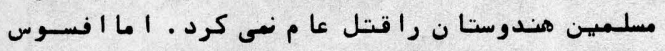

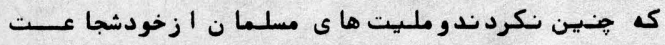

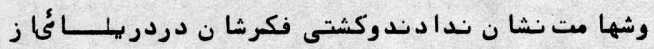

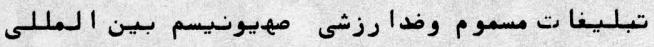

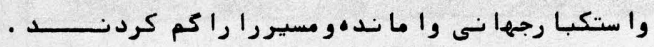

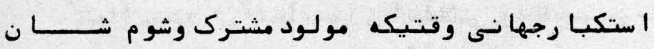

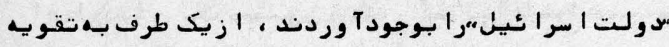

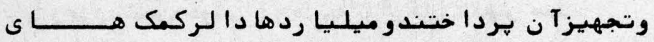

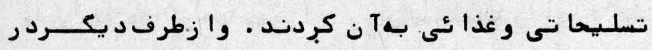

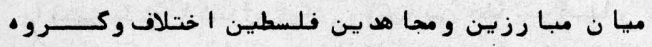

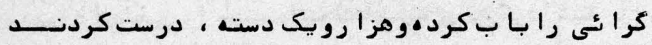

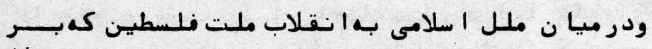

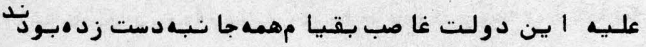

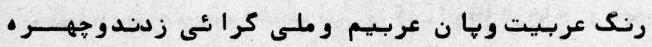

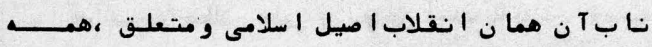

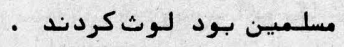

وقا تلـوا فى سبيل اللـها لذذين يقا تلـونك

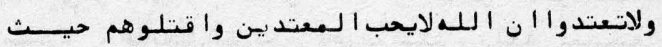

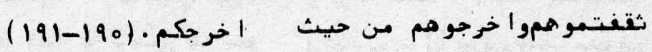

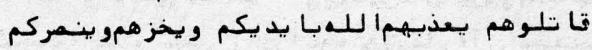

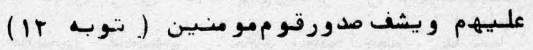

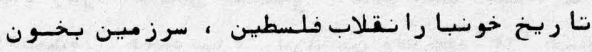

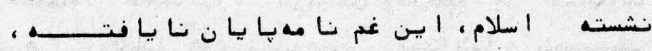

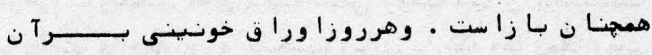

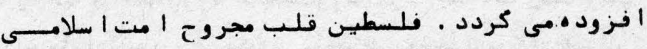

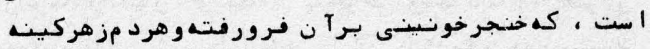

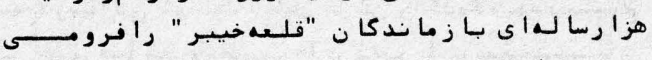

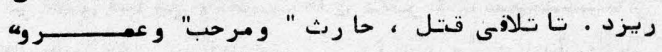

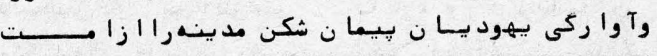

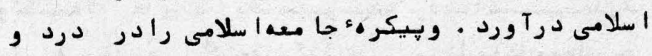

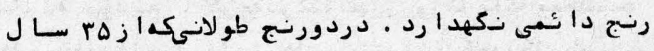

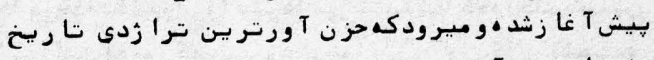

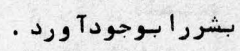

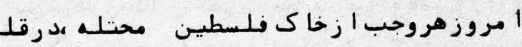

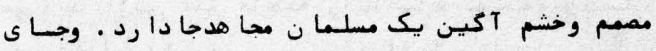

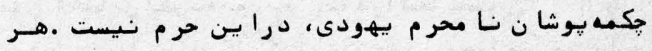

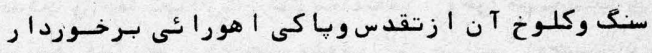

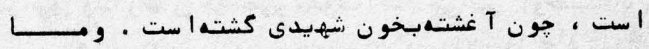

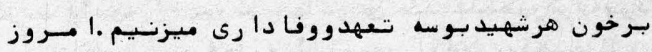

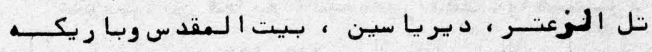

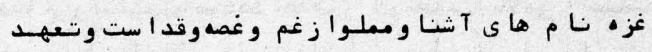

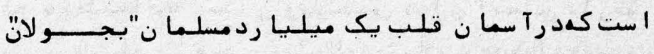

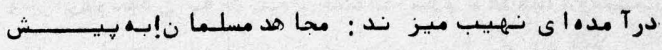

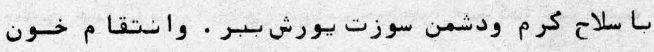

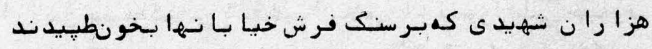

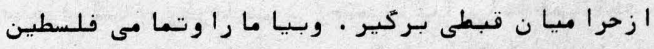

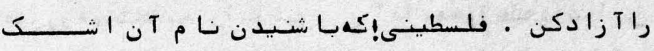

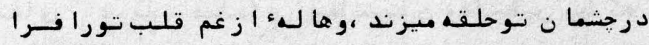

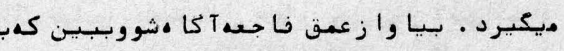

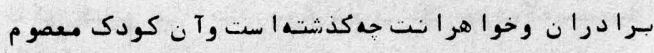

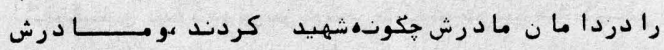


تركستان است " . را • صحيح مبا رزه وكي

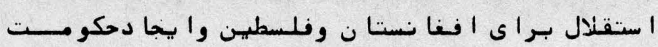

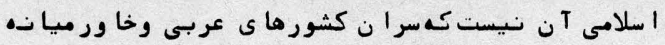

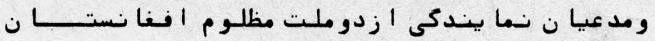

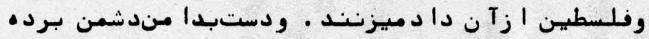

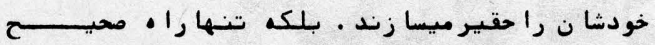

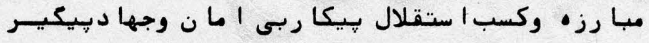

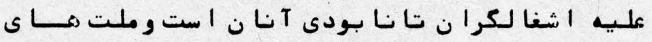

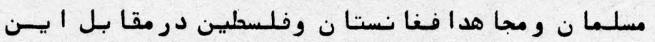

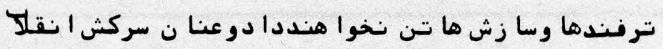

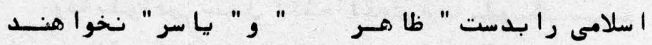

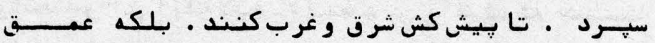

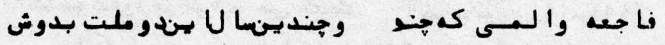

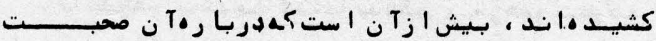

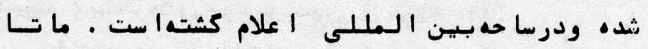

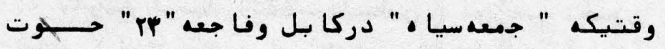

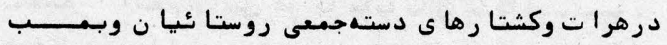

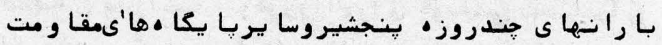

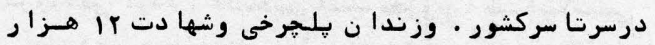

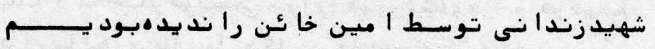

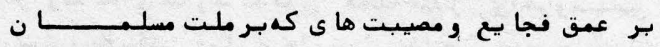

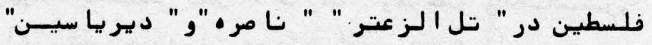

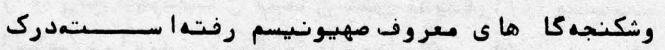

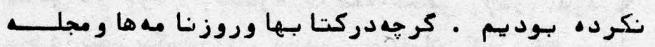

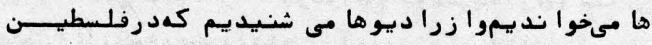

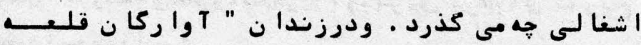

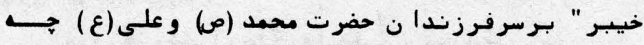

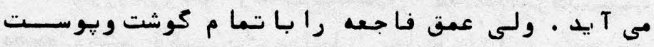

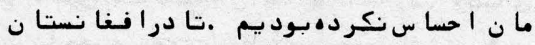

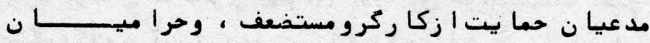

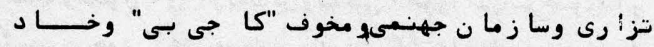

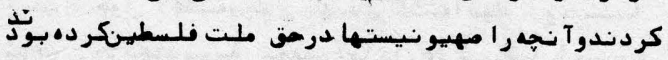

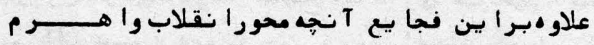

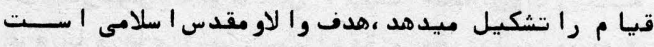

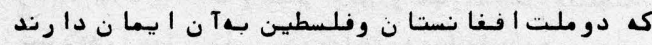

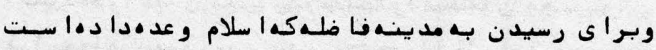

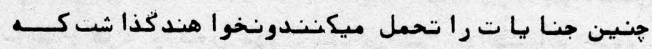

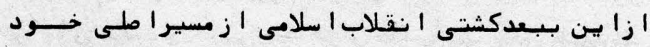

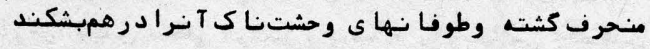

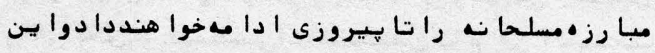

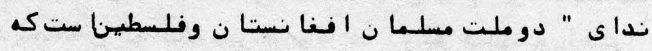

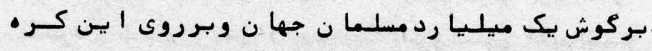

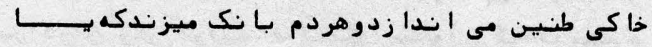

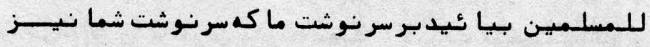

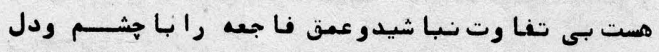

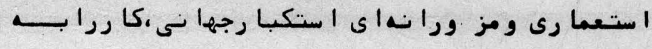

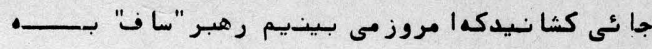

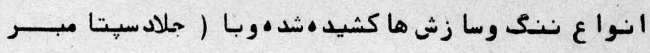

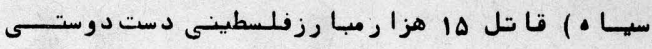

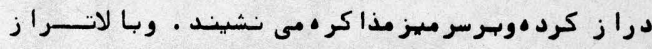

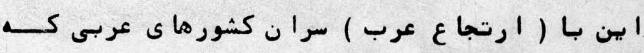

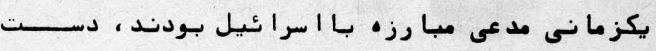

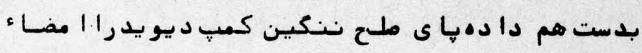
• ارتجا ع عرب وسرا ن كشور ها ع عربسى كهخـود

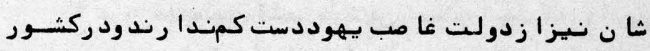

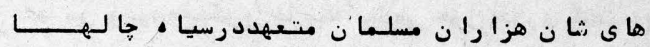

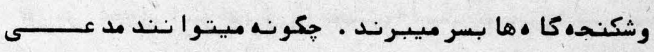

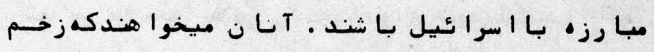

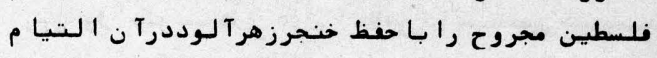

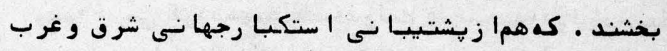

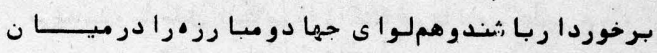

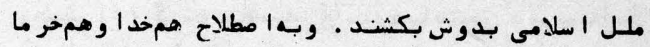

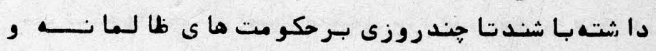

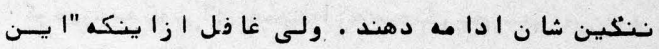

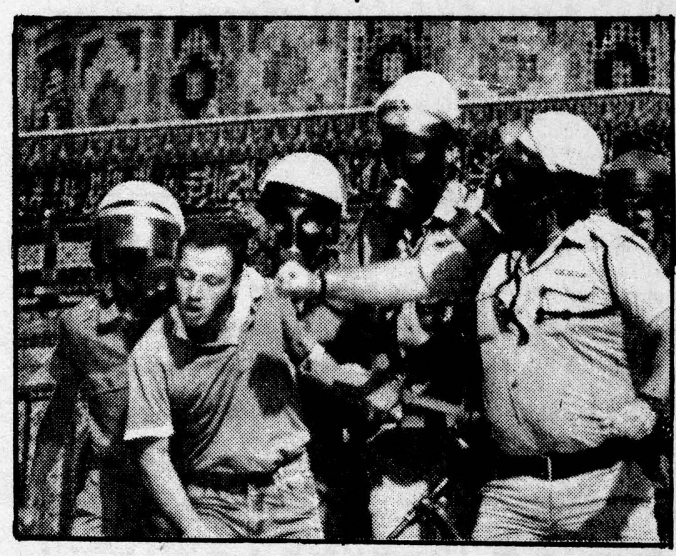

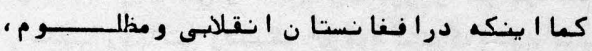

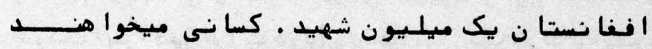

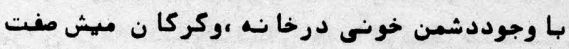

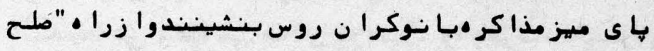

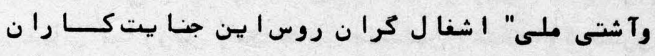

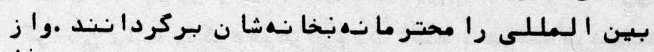

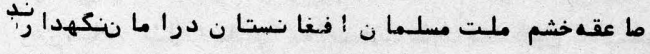

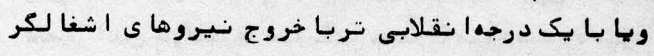

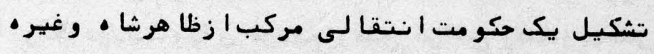

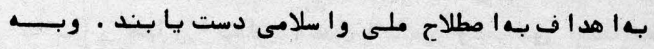

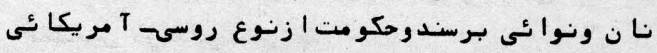

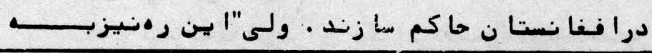




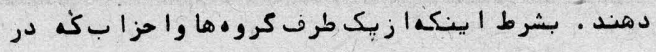

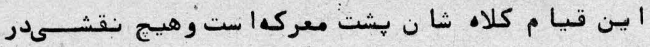

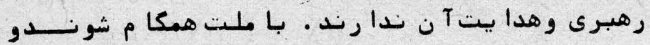

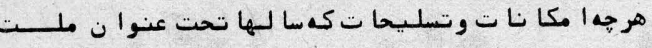

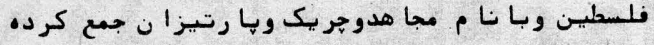

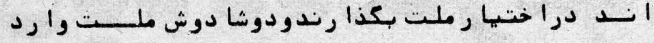

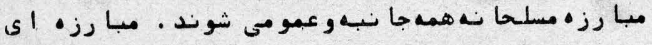

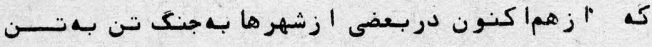

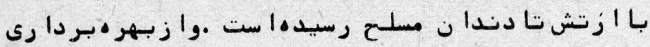

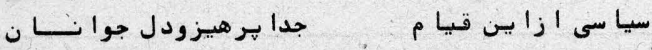

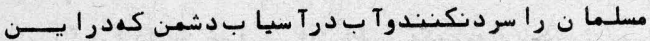

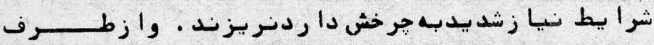

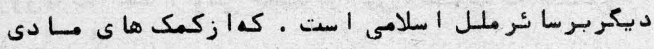

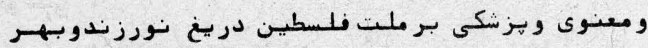

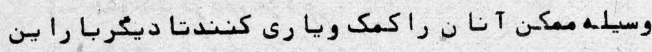

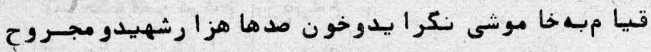

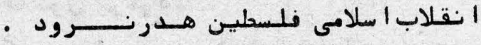

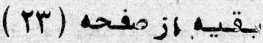

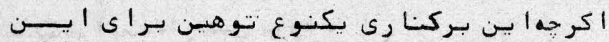

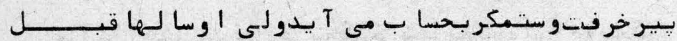

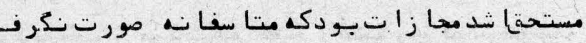

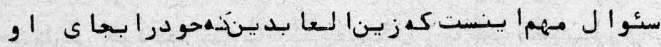

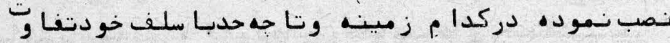

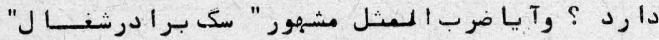

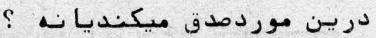

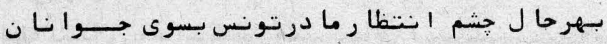

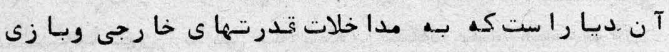

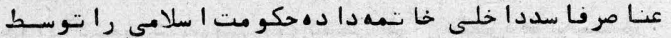

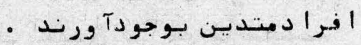

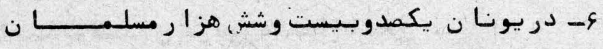

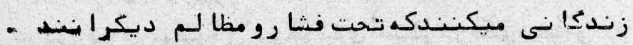

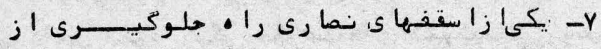

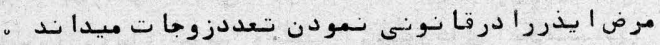

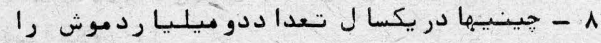

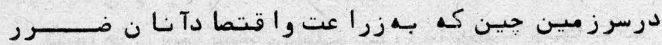

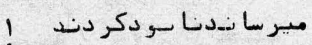

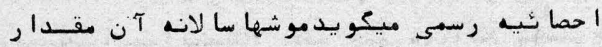

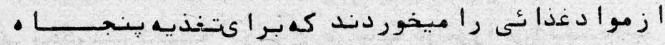

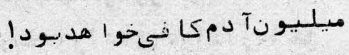

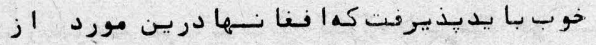

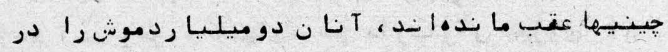

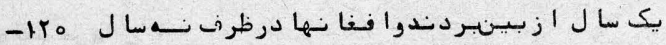

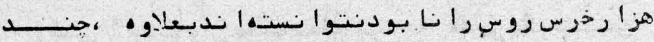

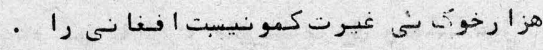

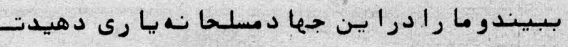

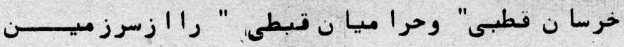

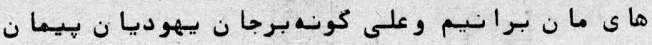

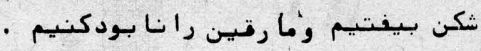

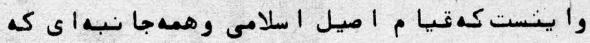

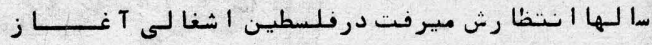

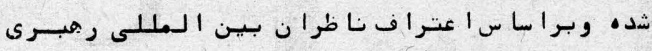

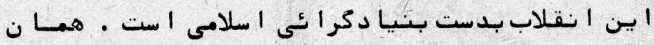

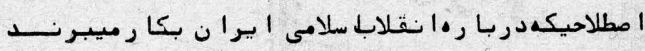

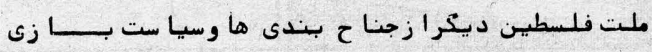

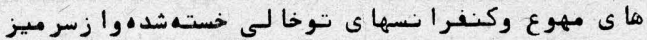

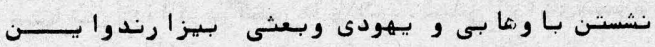

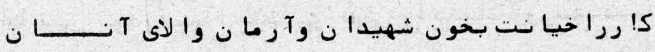

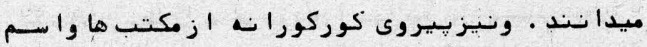

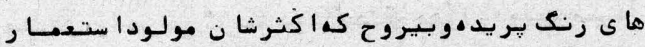

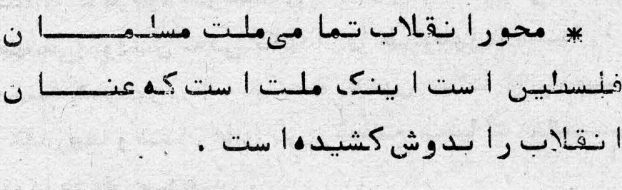

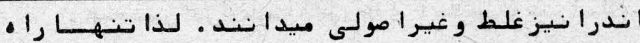

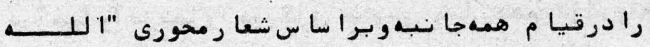

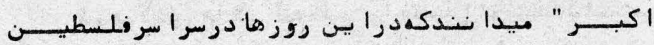

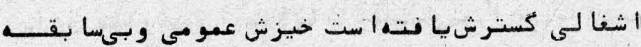

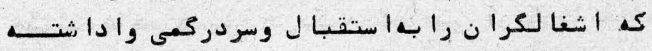

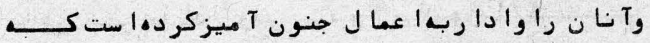

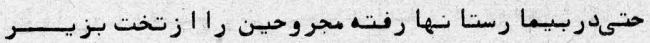

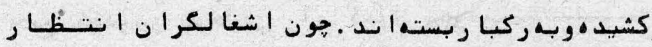

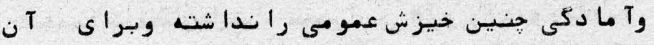

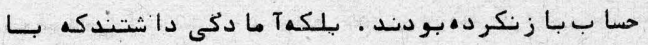

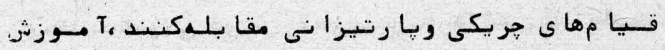

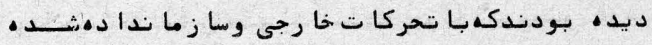

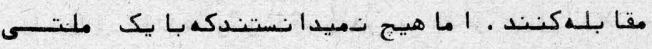

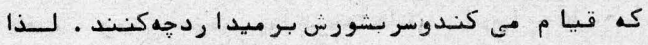

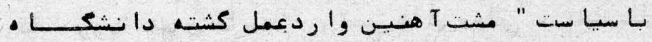

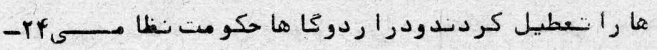

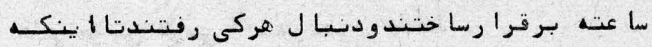

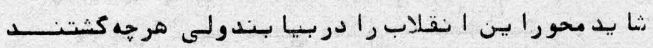

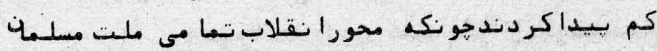

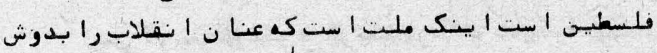

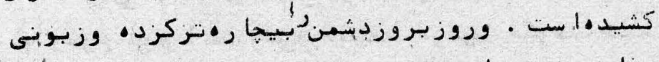

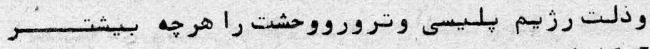

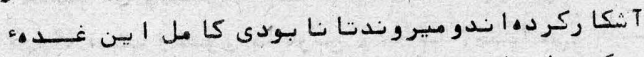

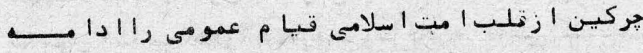




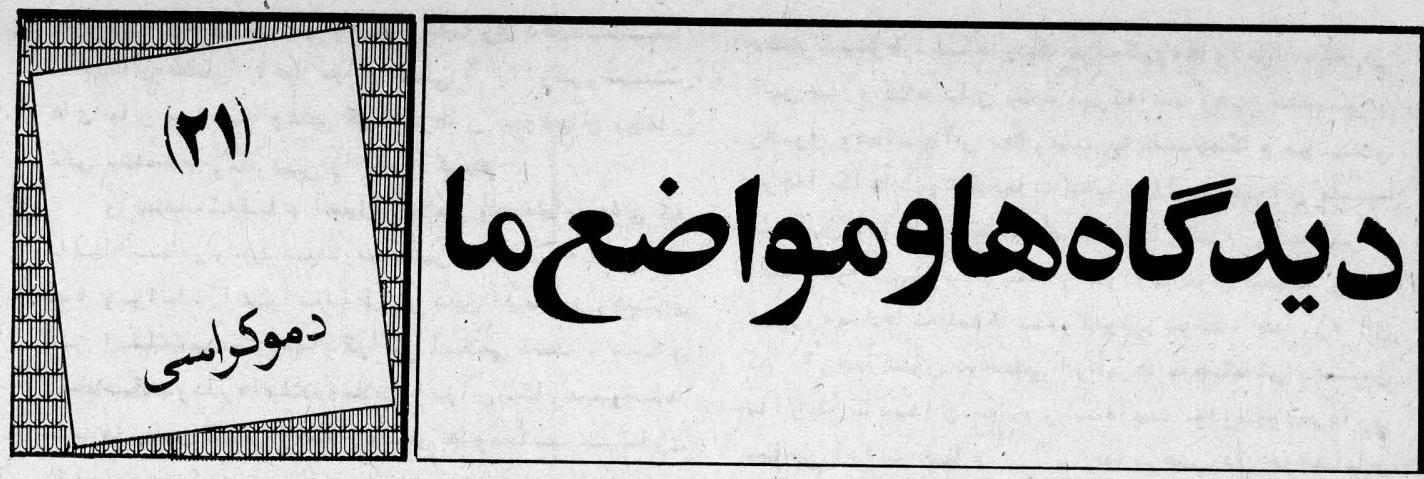

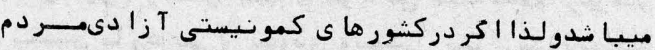

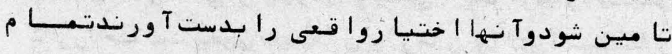

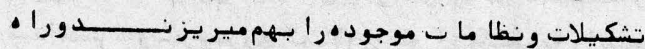

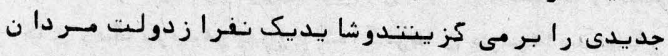

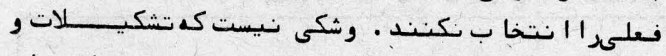

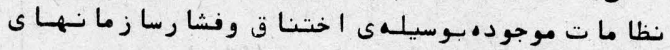

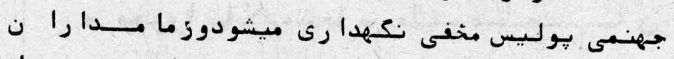

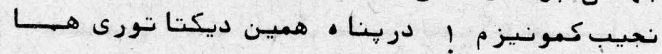

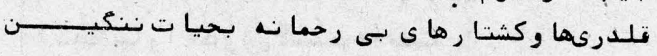

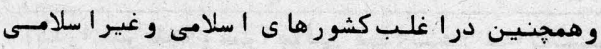

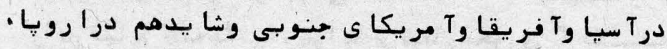

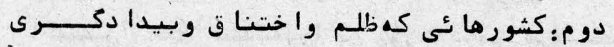

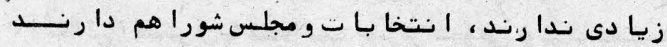

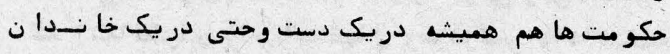

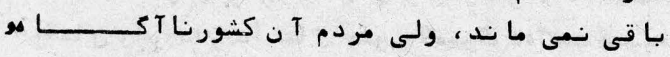

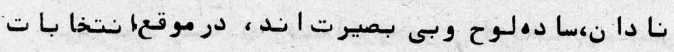

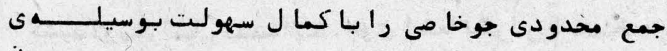

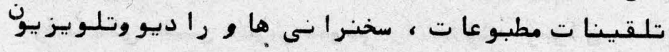

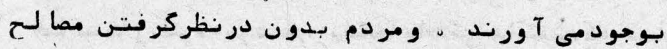

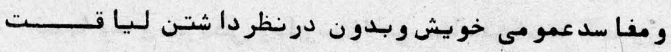

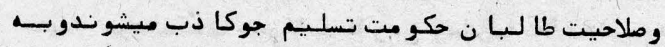

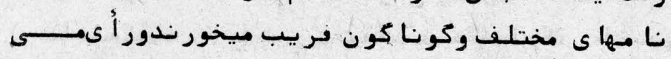

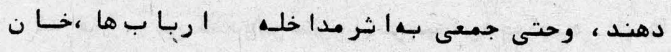

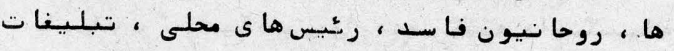

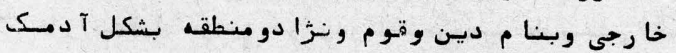

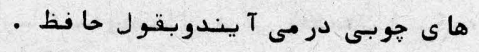

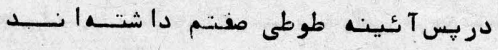

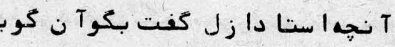

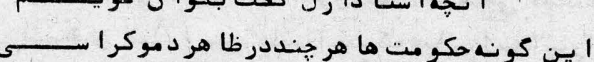

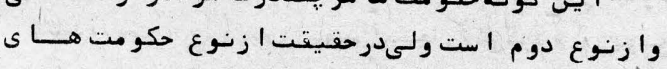

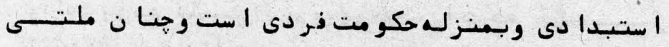

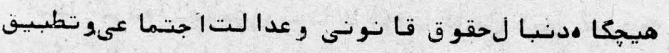

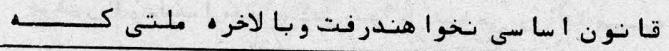

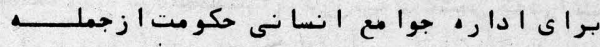

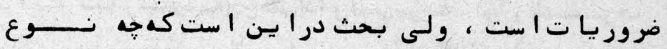
حكو متى ؟

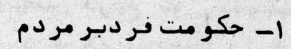

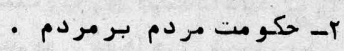

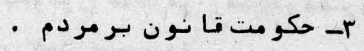

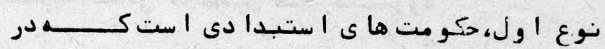

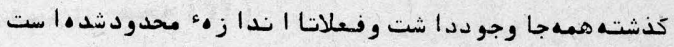

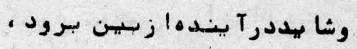

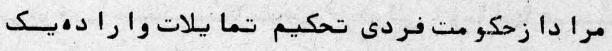

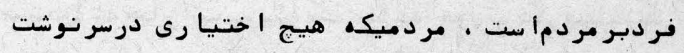

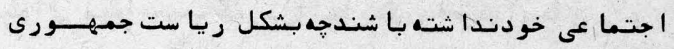

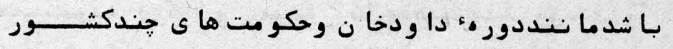

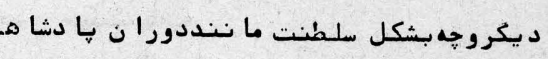

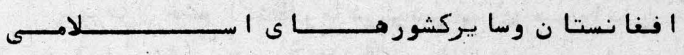

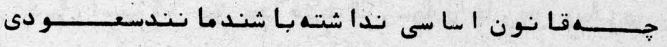

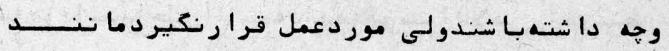

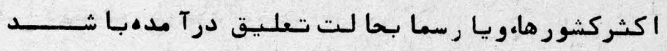

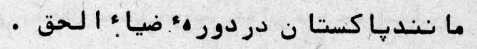

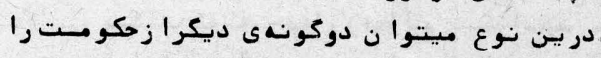

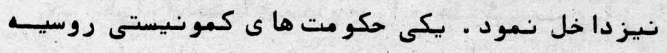

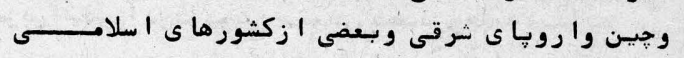

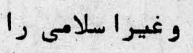

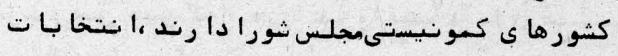

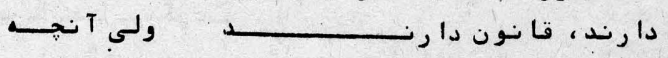

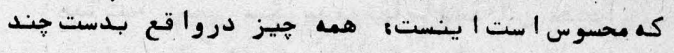

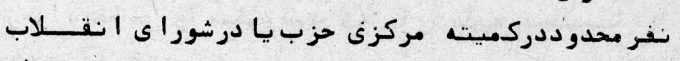

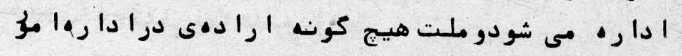

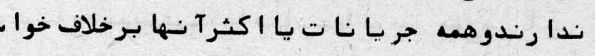

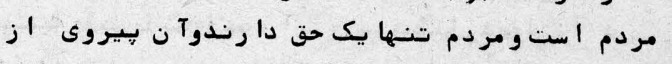

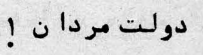

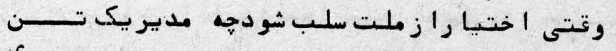

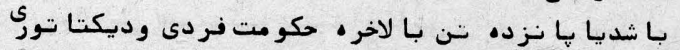


اروسا ل سفرا بـدولت هاى غيرا سلامى وتبول كردن

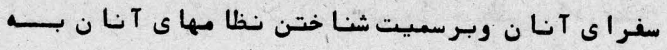

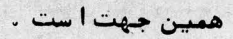

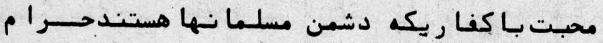

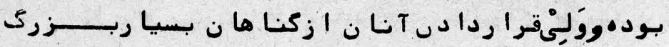

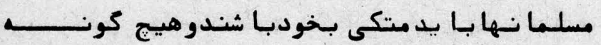

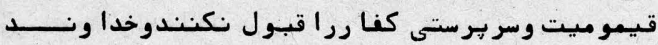

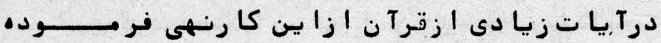

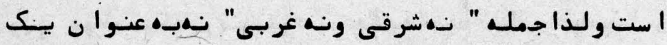

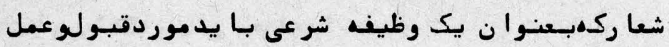

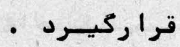

\section{مiاهنباسلومى}

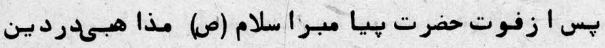

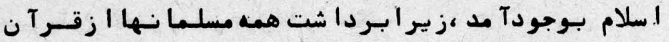

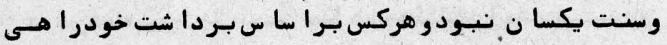

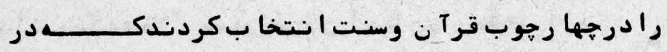

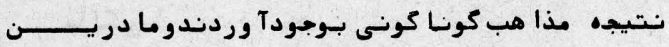

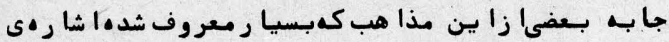

$$
\text { ميكنيم }
$$

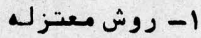

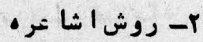

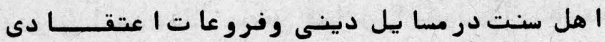

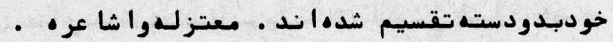

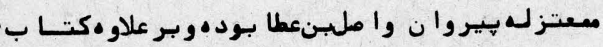

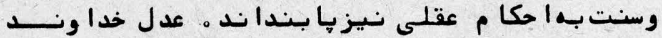

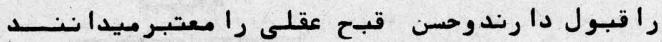

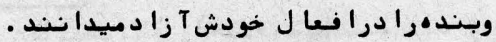

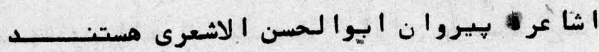

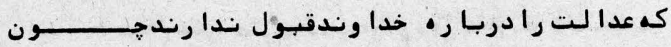

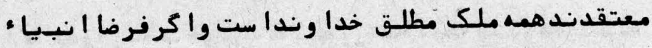

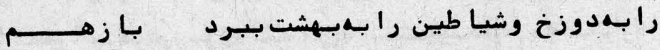

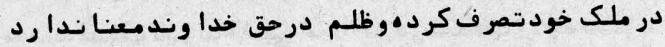

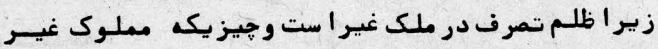

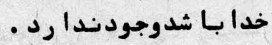

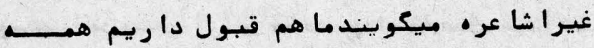

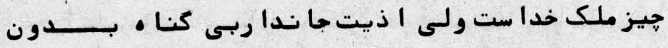

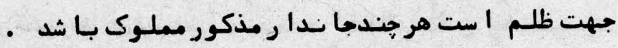

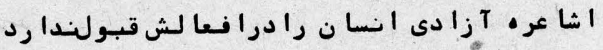

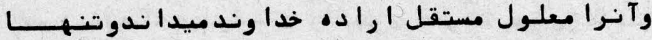

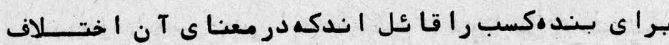

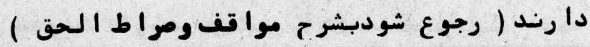

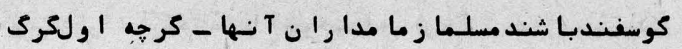

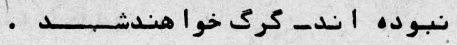

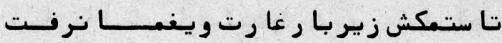

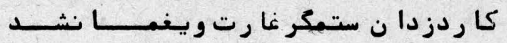

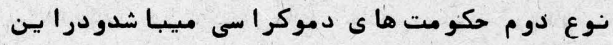

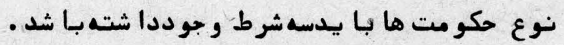

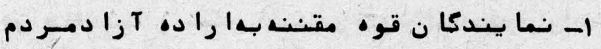

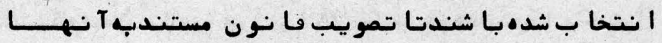

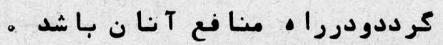

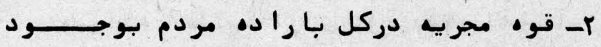

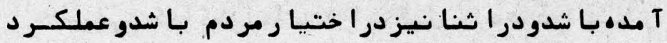

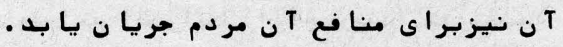

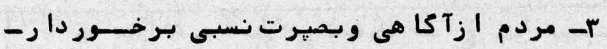

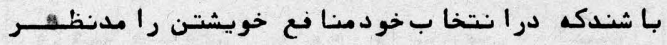

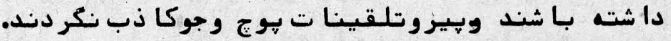

\section{حكومت اسلامى بكونه/ســ}

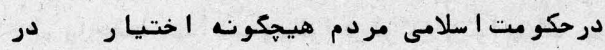

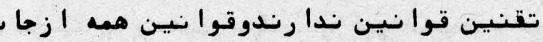

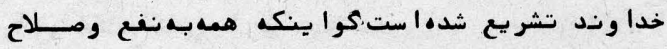
بشر يت است مان

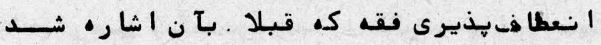

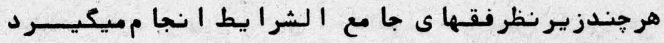

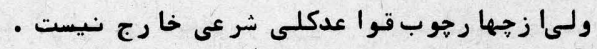

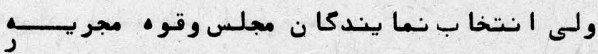

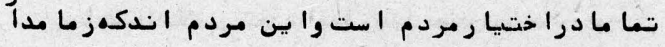

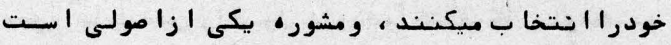

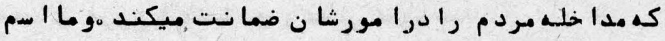

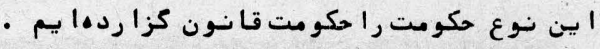

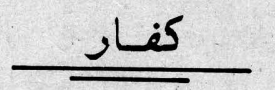
كفا ردريك تقبيم دودستهاند. .

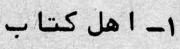

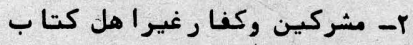

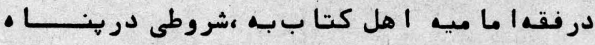

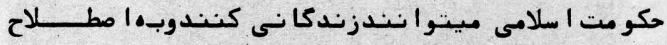

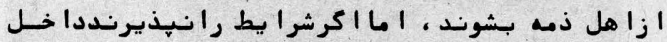

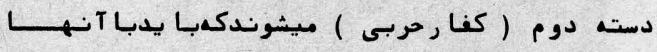

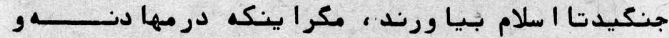

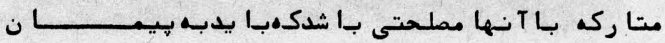

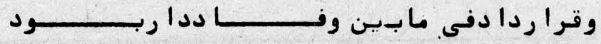




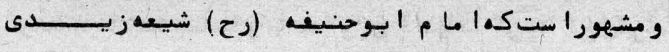

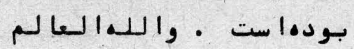

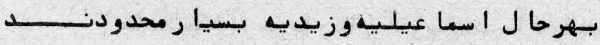

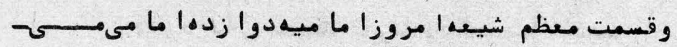

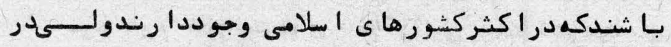

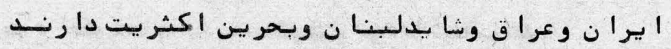

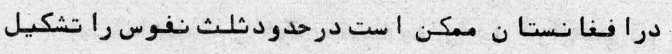

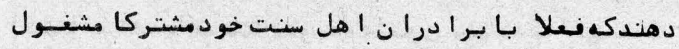

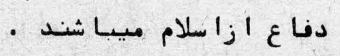

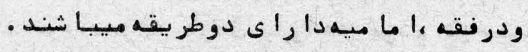

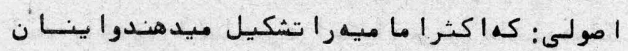

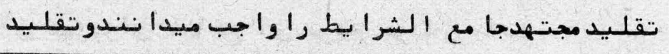

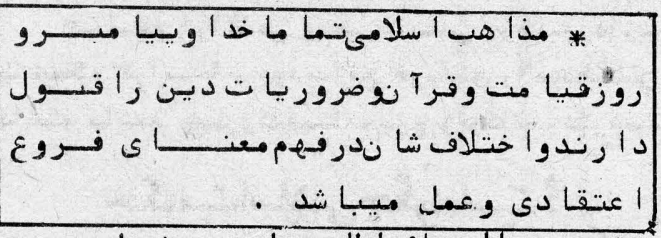

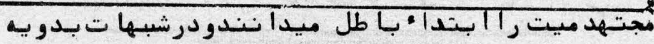

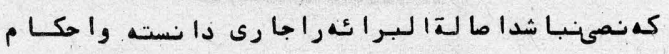

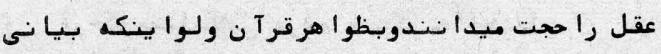

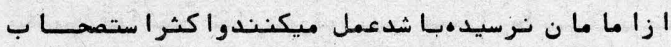

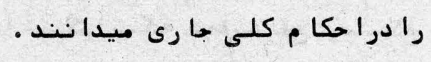

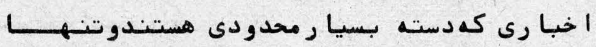

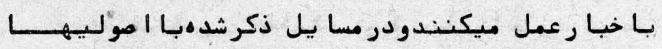

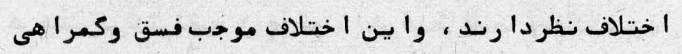

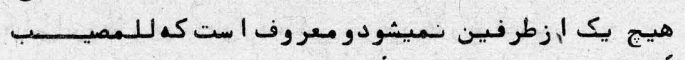

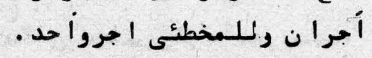

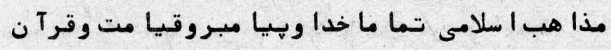

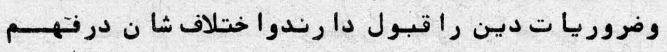

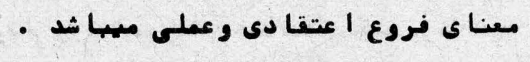

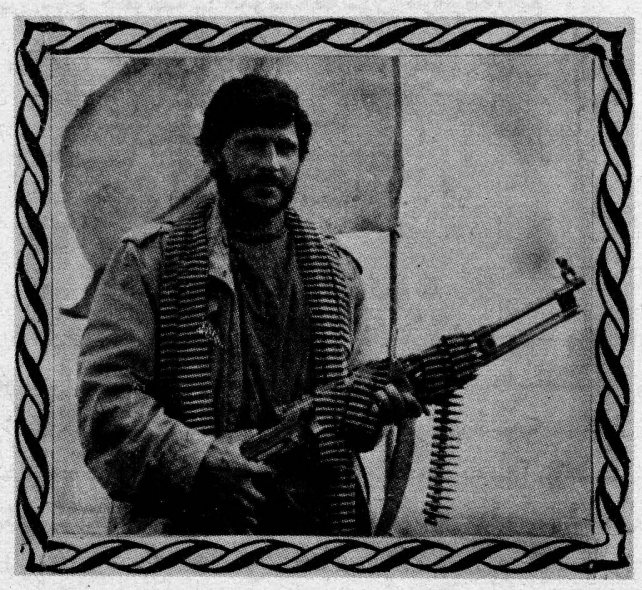

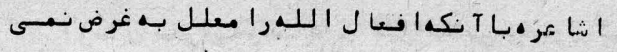

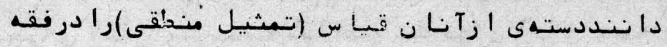

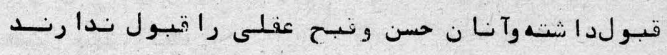

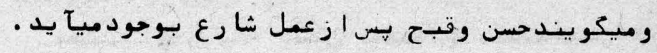

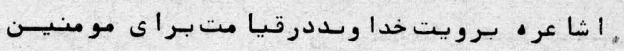

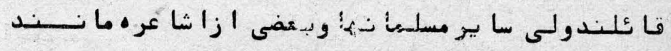

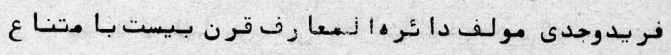
رويت خدا ورندقا ئانـد

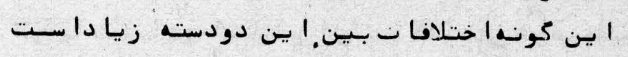

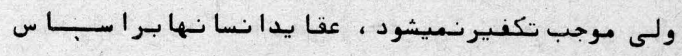

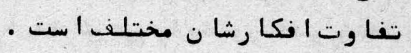

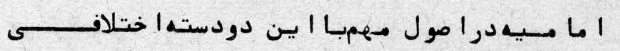

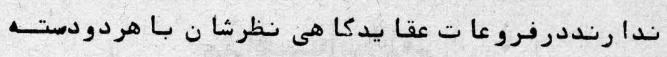

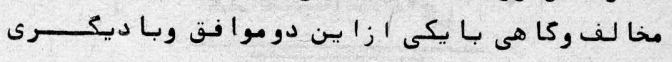

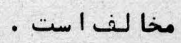

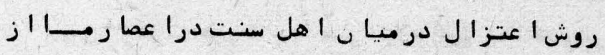
ييروا ن كمترى برخور دارا است .

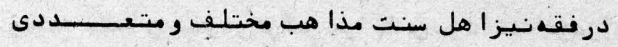

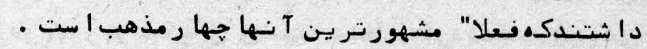
حنا لـى حنى

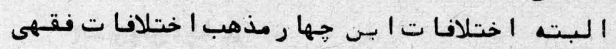

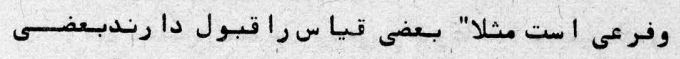

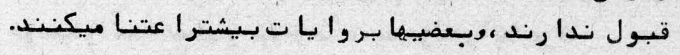

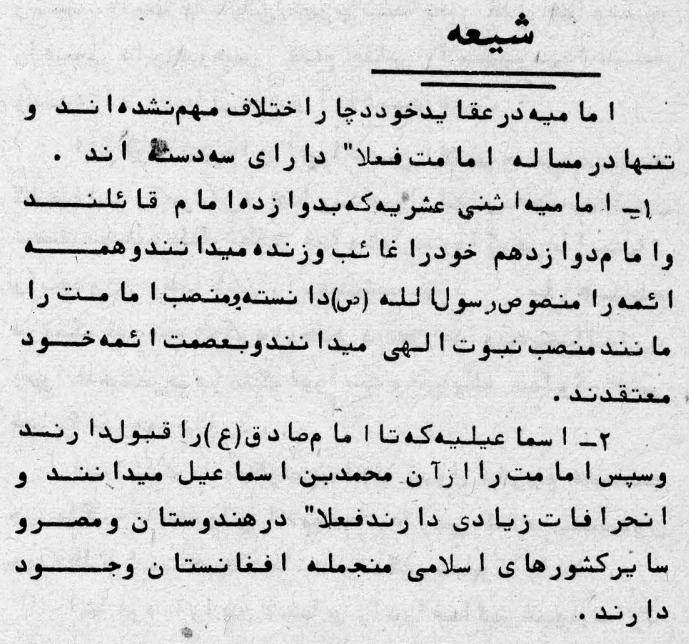

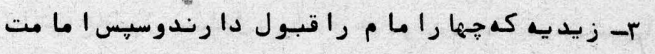

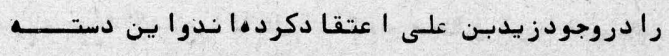

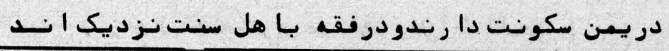




\section{جهاددواسلام}

\section{每}

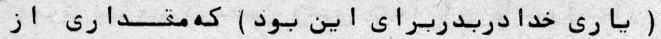

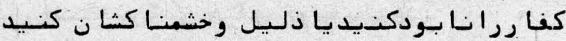

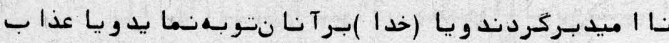

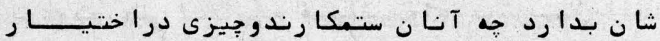

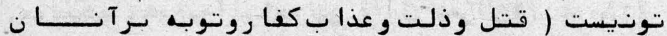

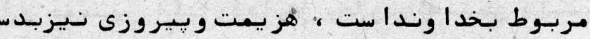

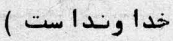

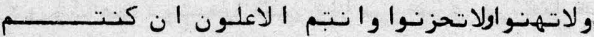

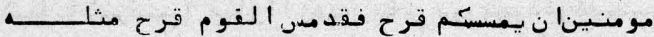

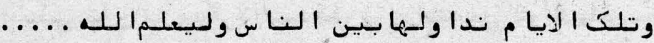

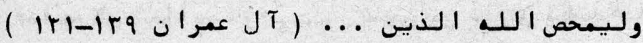

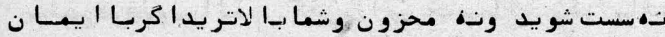

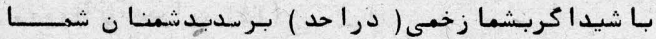

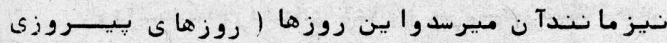

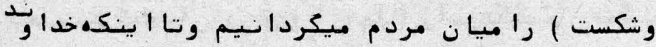

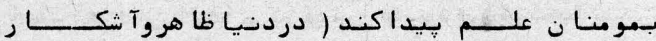

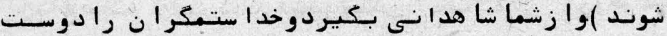

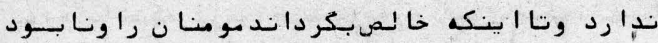

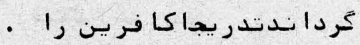

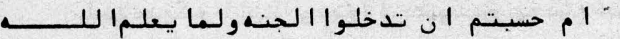

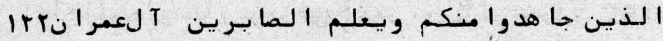

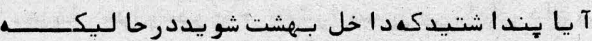

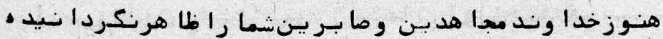

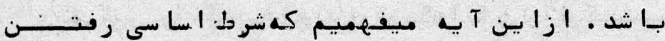

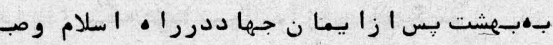

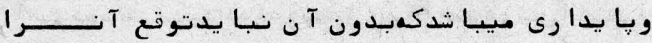

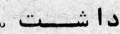

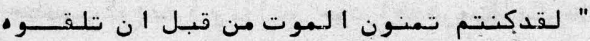

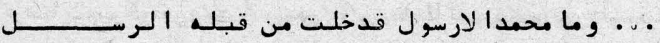

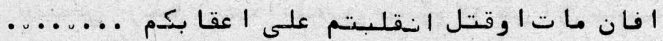

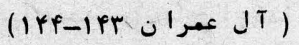

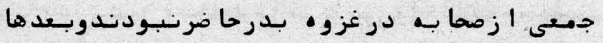

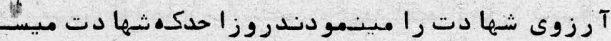

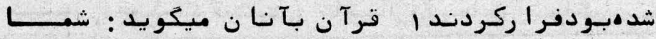
ا ستقا مت (YI)

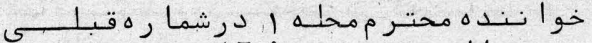

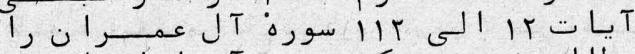

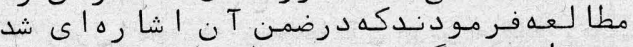

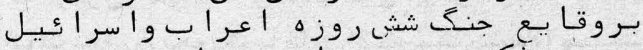

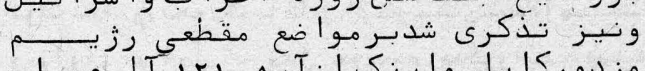

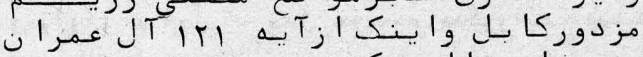

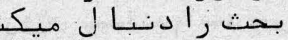

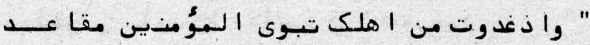

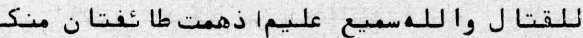

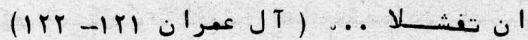

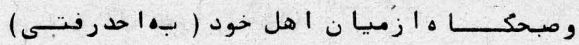

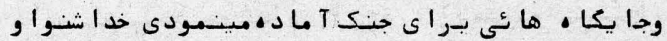

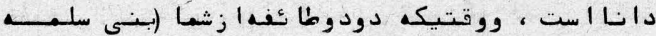

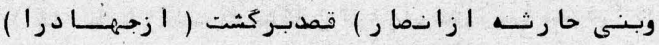

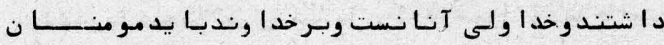

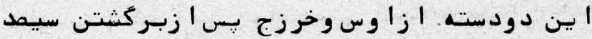

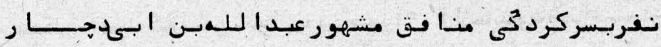

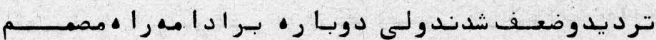
شدند

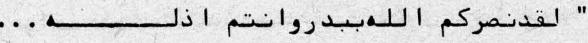

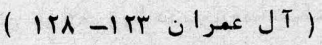

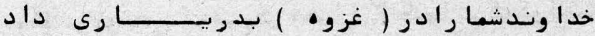

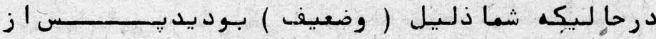

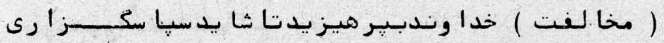

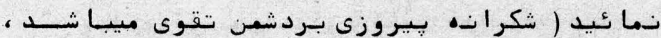

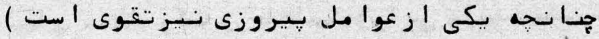

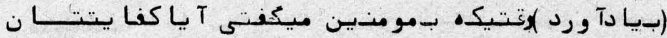

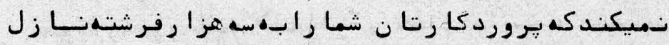

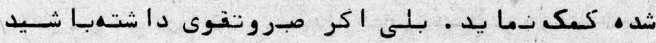

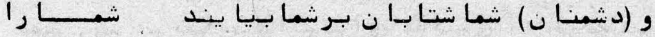

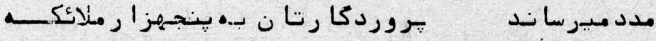

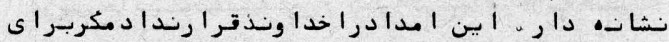

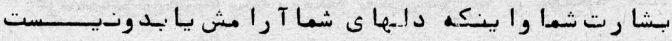

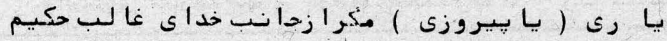




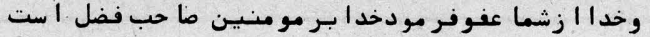

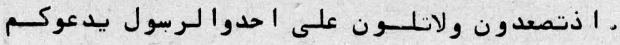

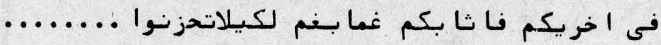

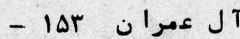

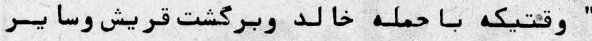

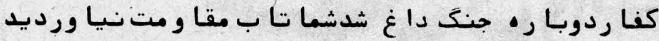

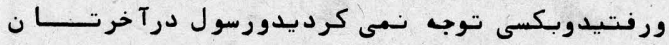

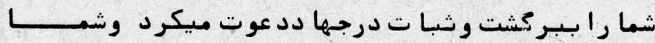

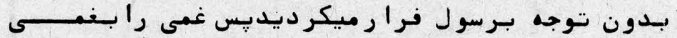

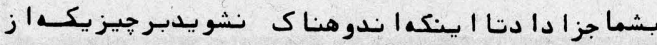

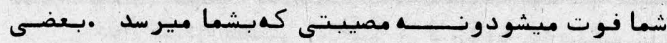

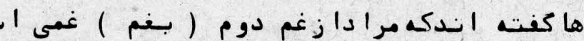

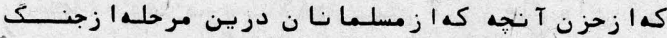

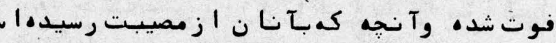

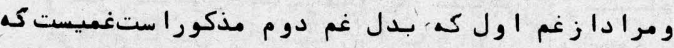

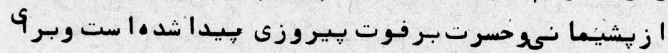

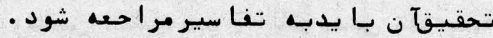

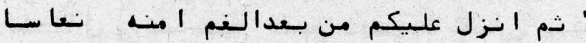

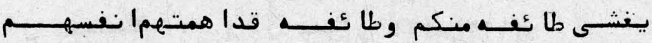

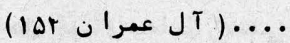

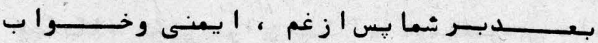

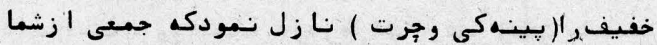

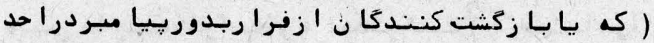

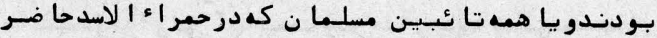

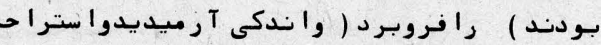

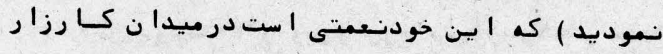

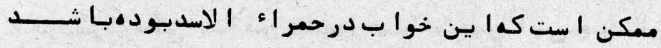

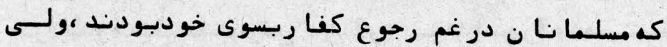

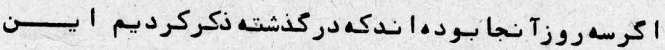

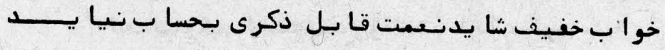

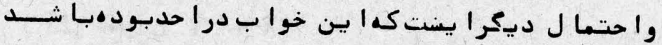

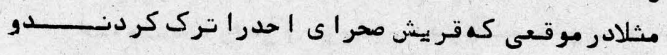

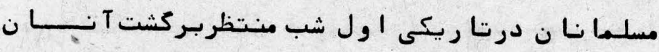

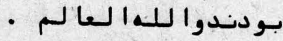

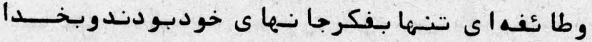

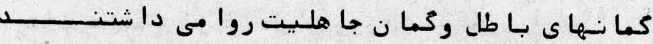

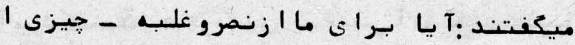

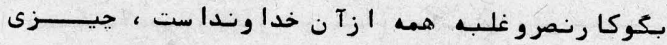

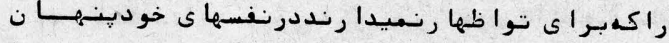

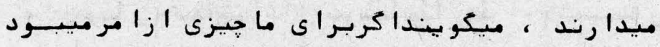

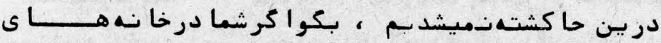

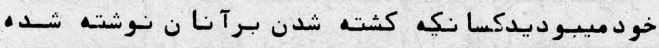

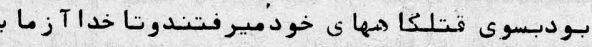

5

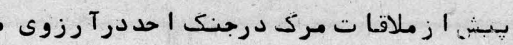

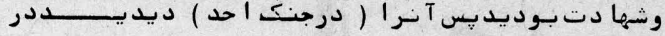

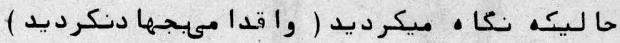

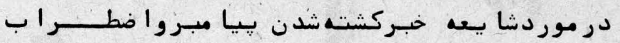

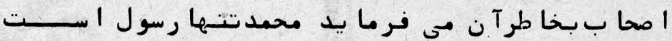

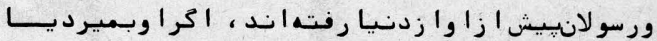

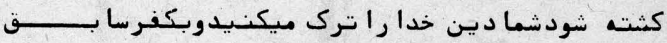

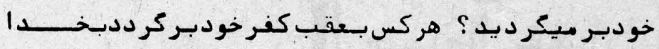

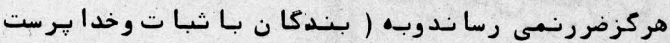

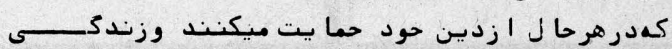

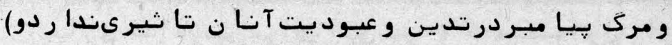

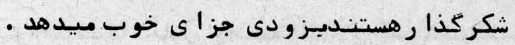

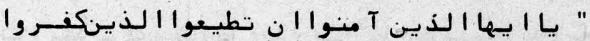

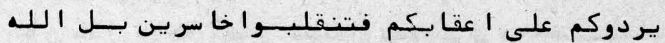

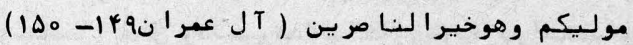

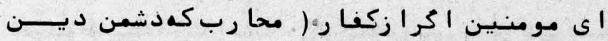

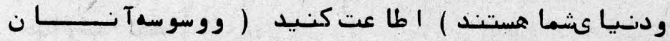

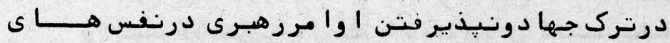

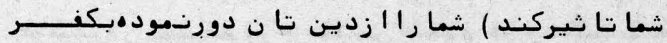

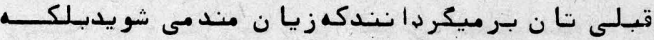

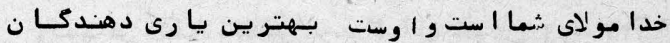

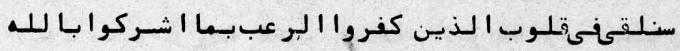

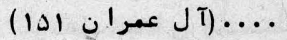

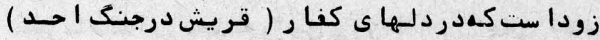

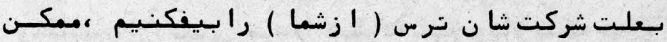

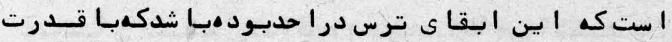

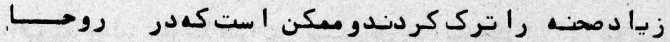

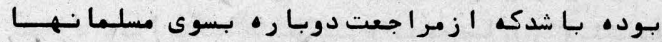

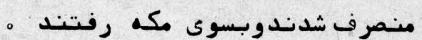

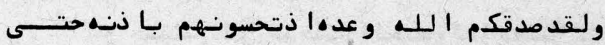

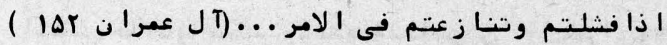

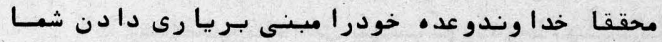

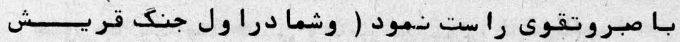

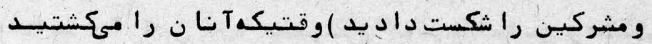

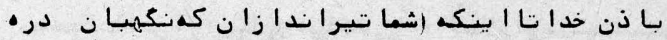

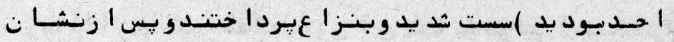

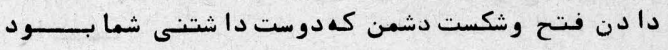

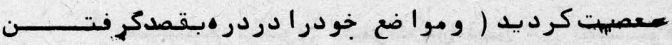

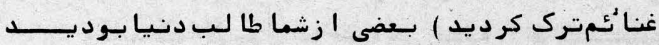

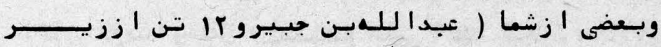

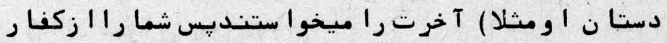

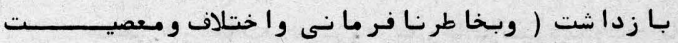

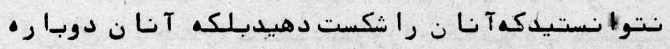

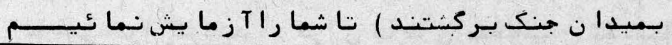




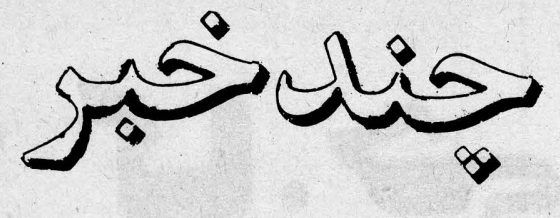

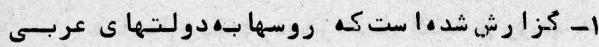

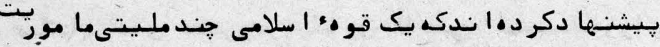

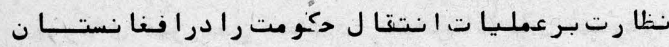

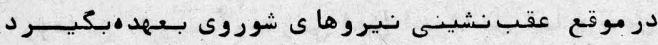

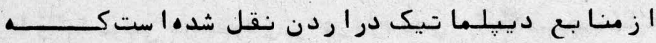

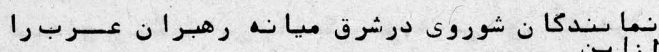

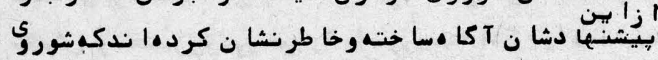

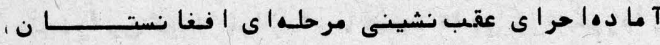

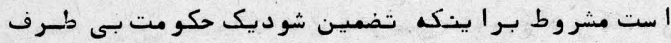

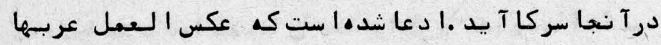

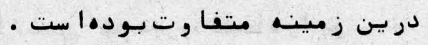

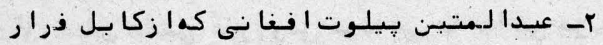

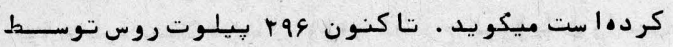

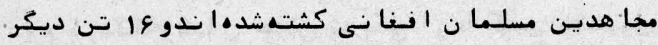

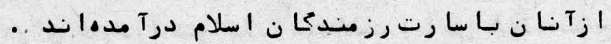

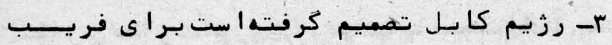

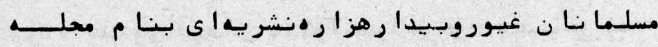

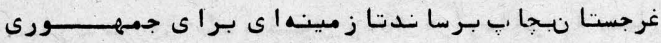

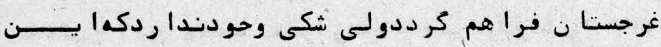

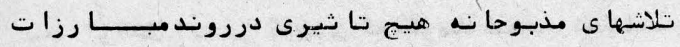

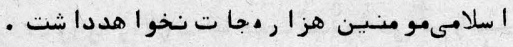

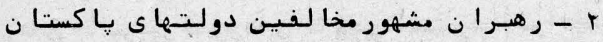

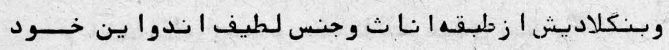

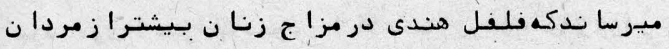

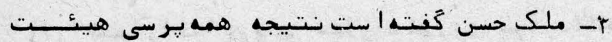

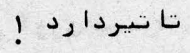

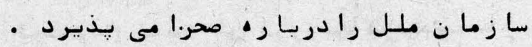

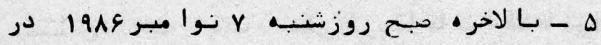

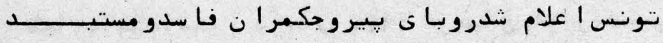

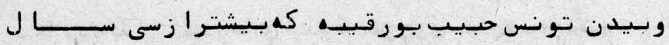

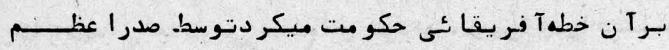

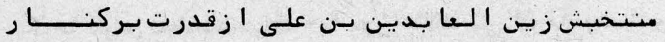

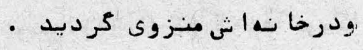

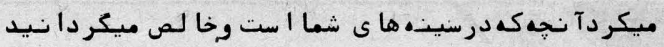

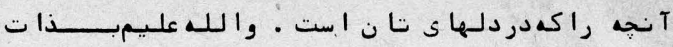

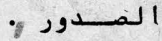

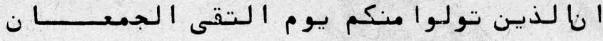

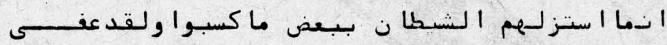

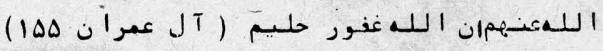

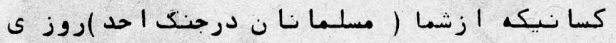

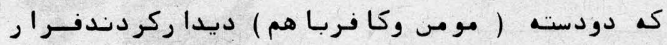

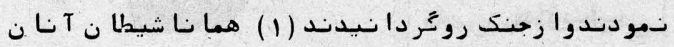

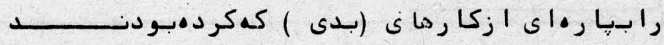

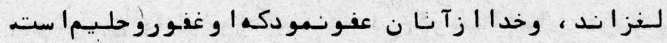

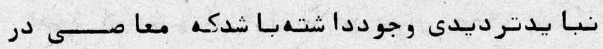

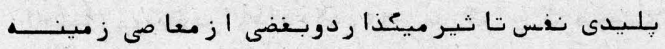

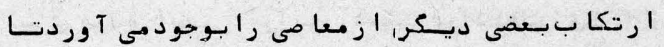

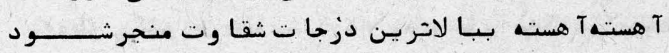

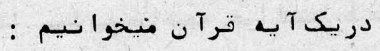

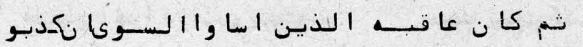

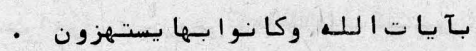

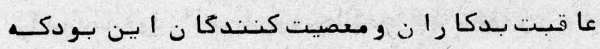

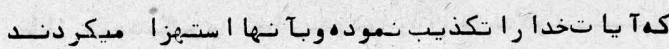

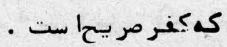

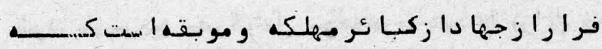

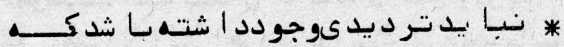

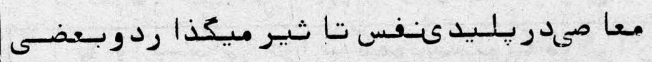

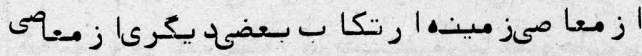

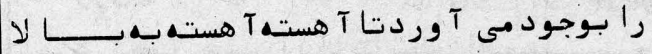

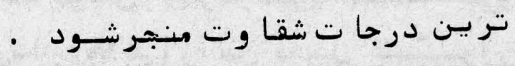

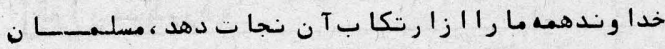

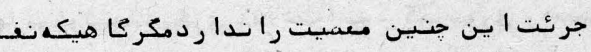

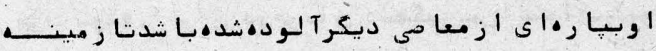

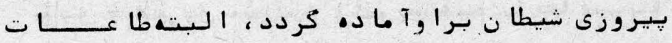

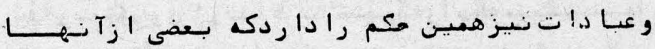

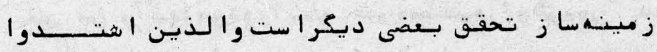
ز.... أدهم هدى

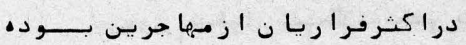

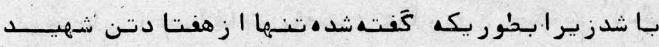

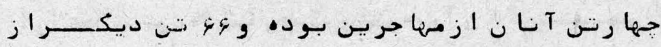

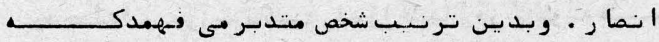

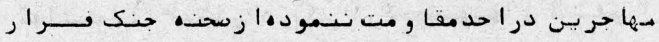




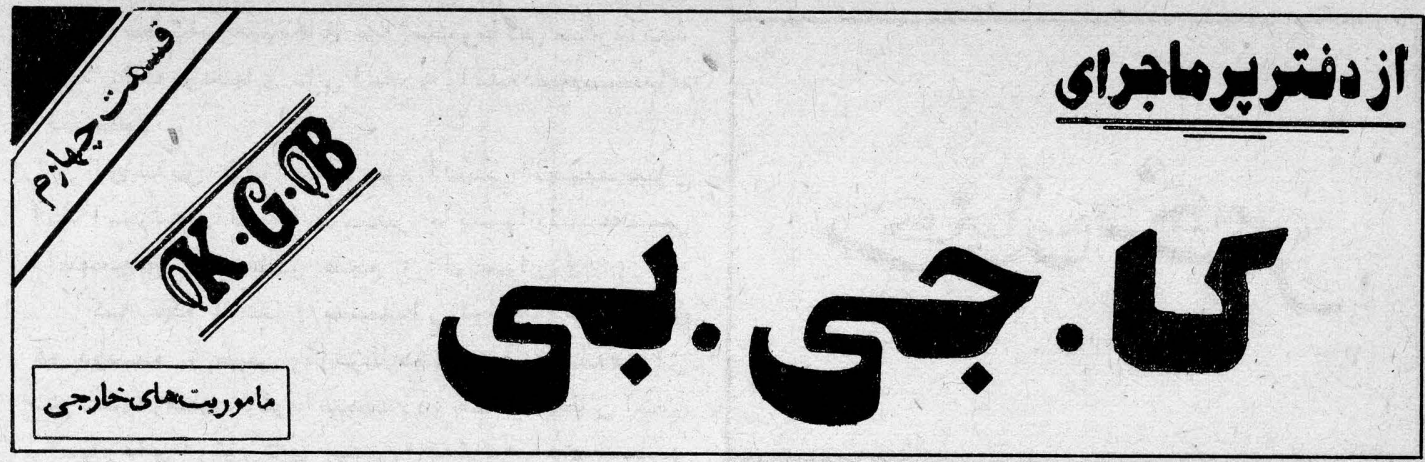

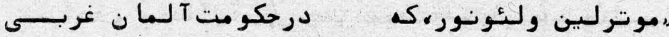

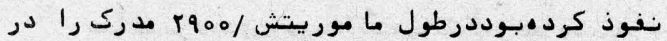

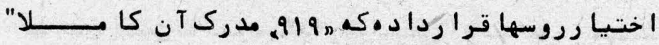

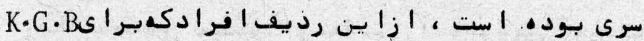

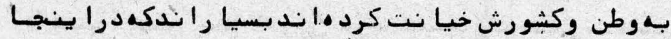

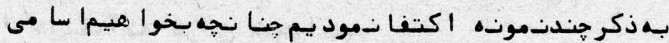

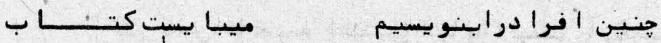

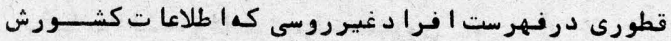

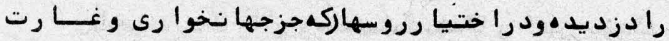

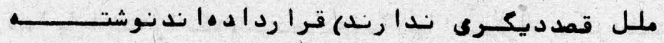

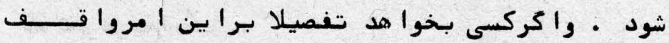

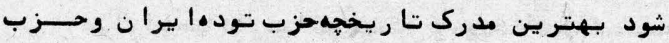

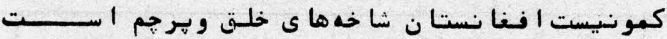

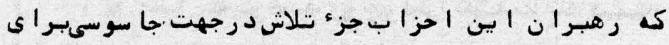

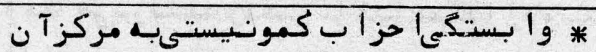
كه شوروىى سبت يك ا مر طبيعىمىيا شد وجاسوسى

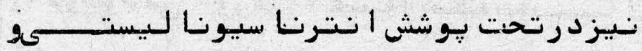

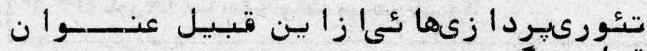

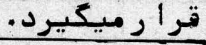

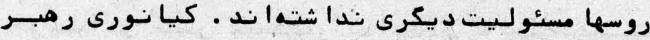

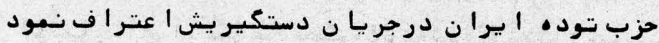

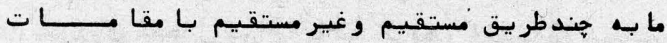

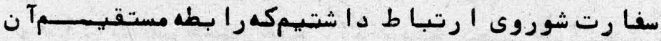

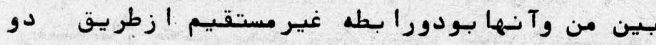

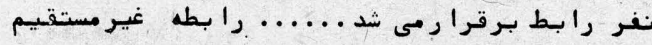

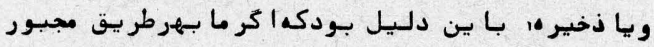

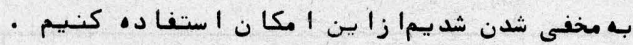

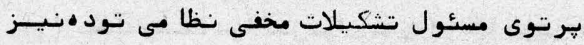

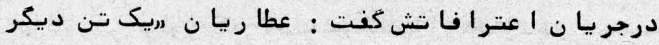

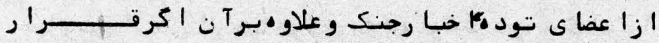

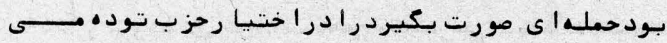

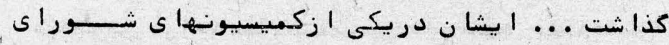

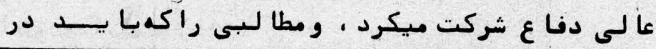

هما نطور يكهد رشما رهقبل كفته شد روسها بـــراى

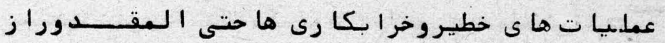

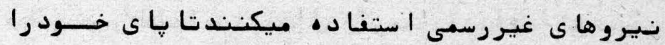

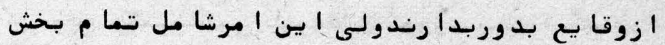

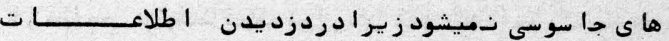

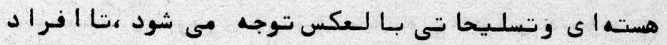

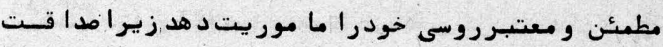

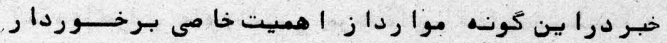

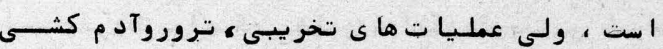

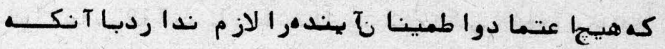

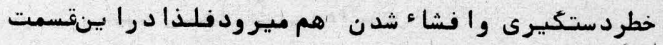

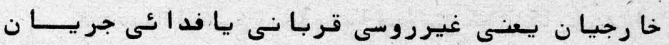

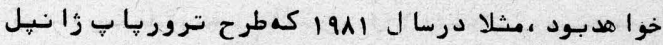

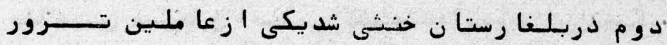

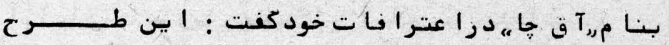

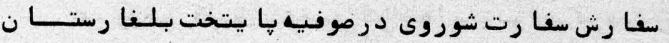

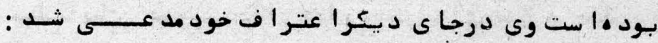

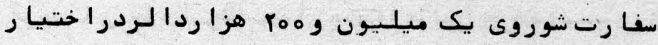

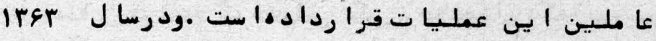

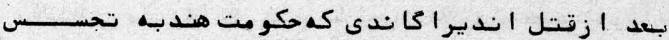

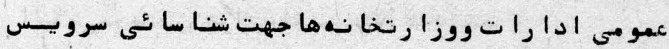

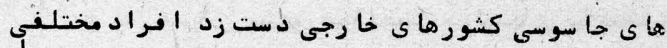

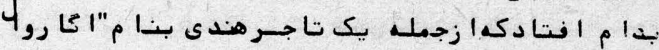

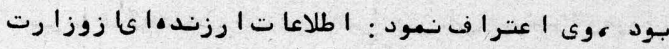

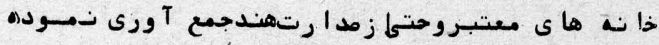

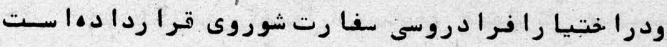

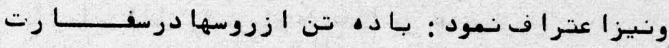

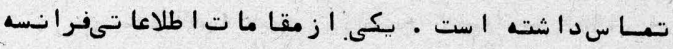

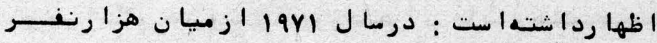

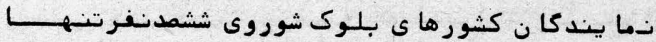

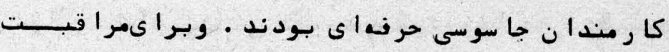

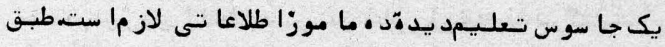

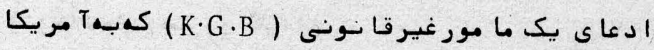

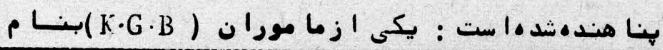




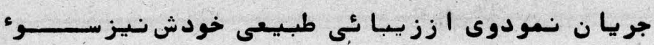

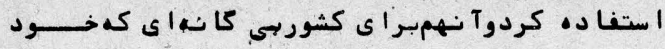

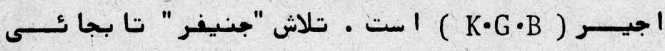

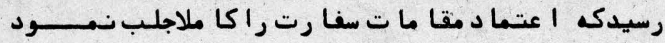

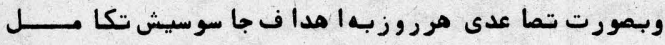

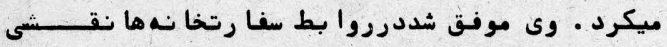

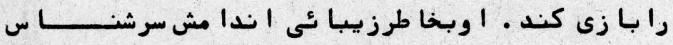

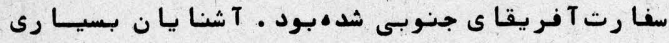

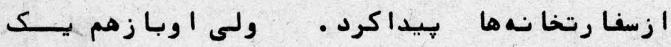

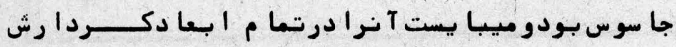

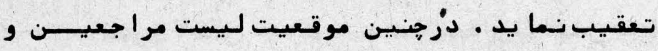

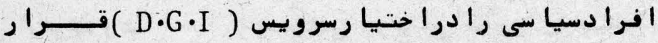

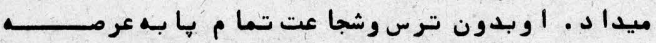

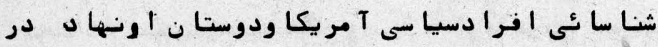

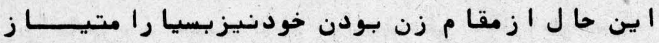

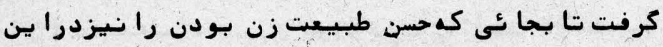

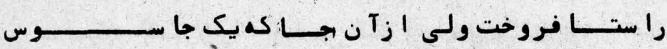

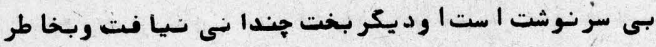

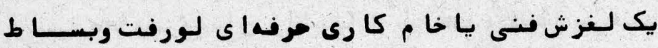

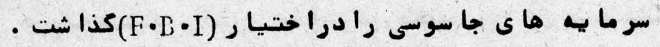

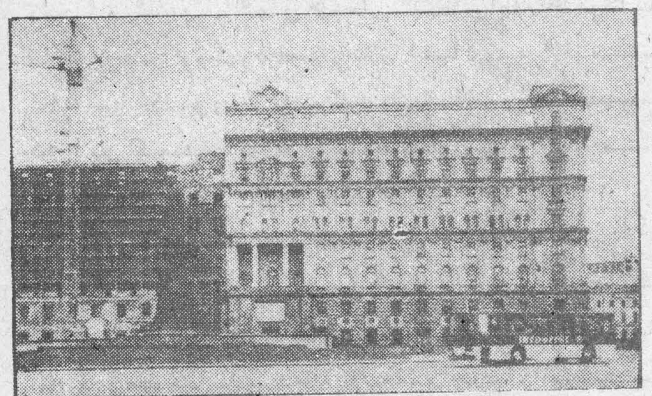

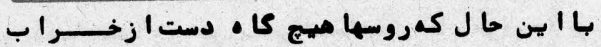

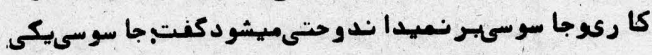

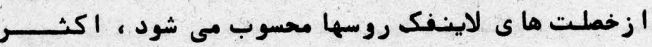

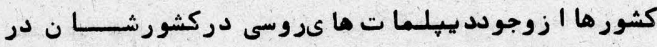

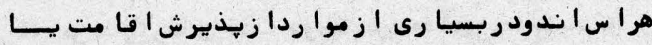

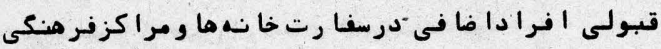

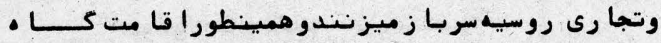

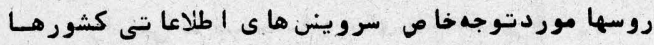

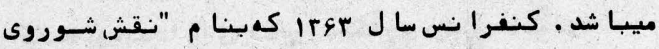

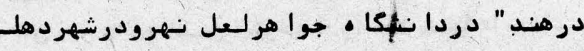

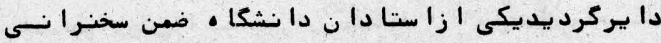

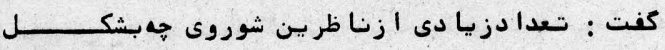

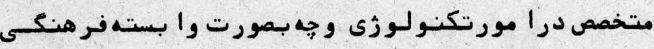

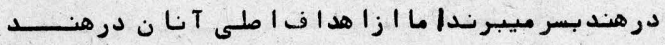

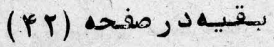

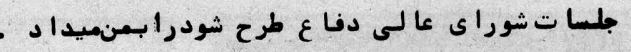

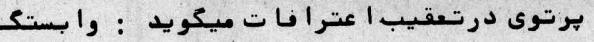

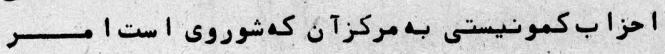

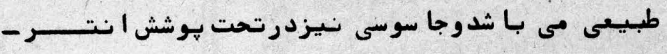

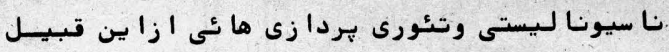

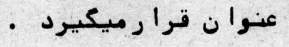

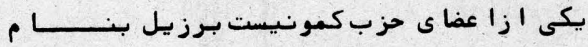

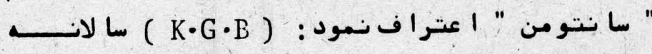

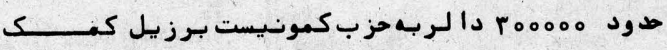

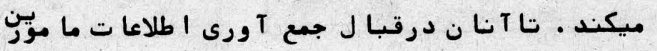

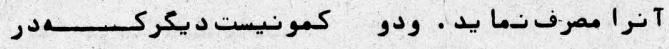

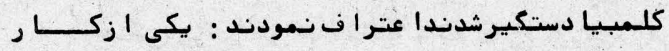

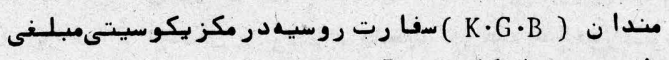

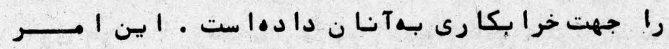

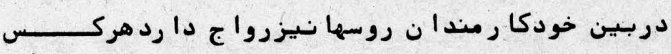

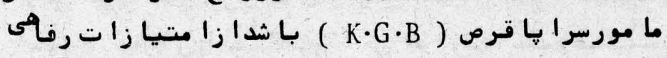

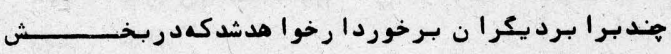

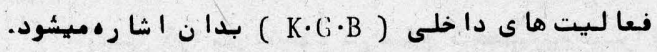

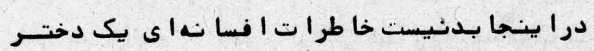

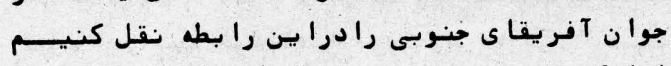

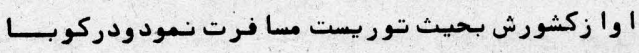

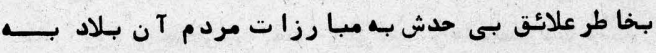

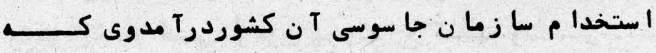

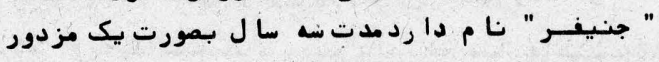

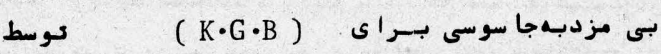

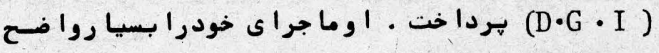

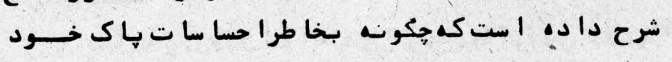

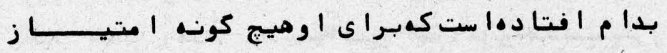

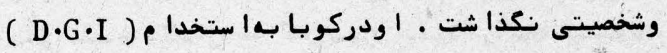

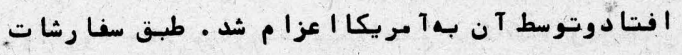

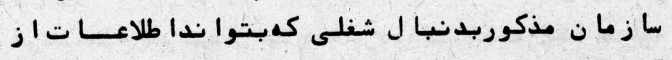

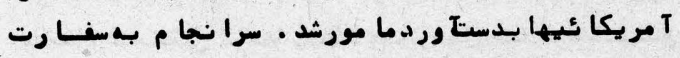

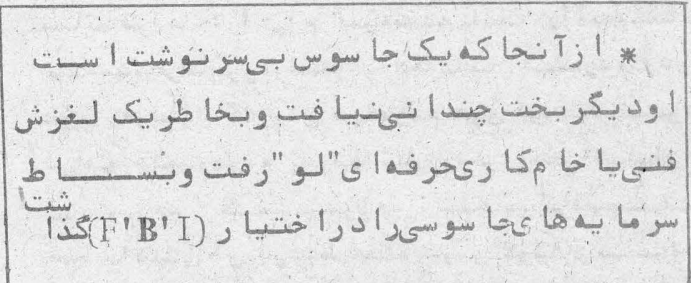

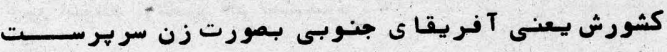

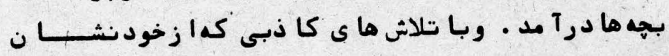

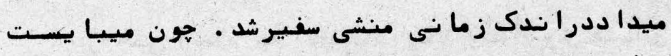

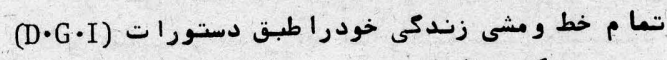

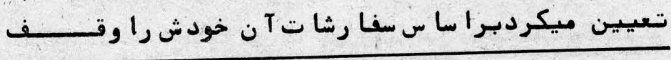




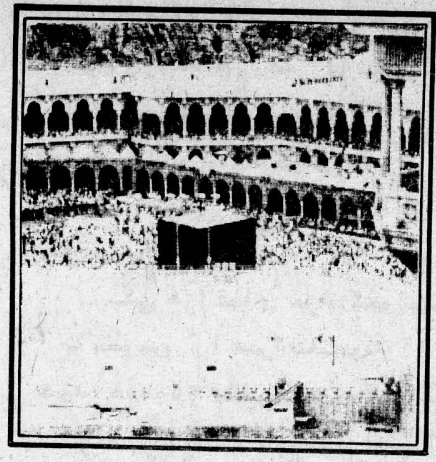

\section{درسوكسفيدجامكان}

خاطراتىازسفرحج

$$
\text { كفا رقريش ميكا ستتد . }
$$

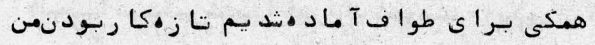

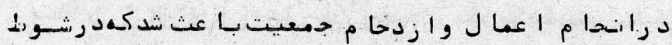

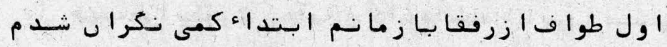

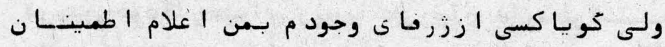

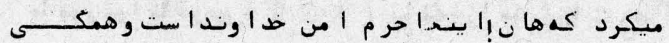

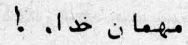

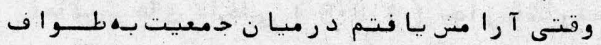

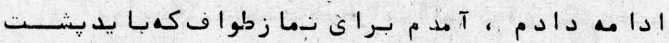

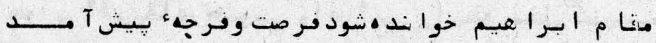

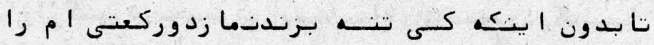

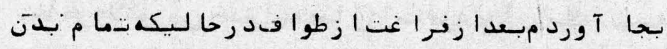

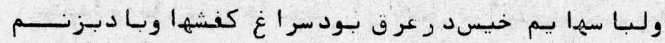

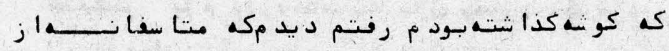

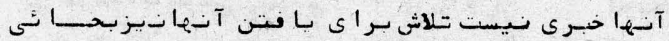

بنا حا ردرحا ل لـ ال ا ميدى ا زبدست آوردن كفشها

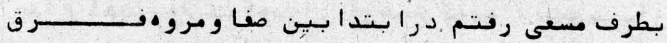

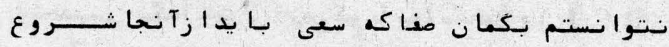

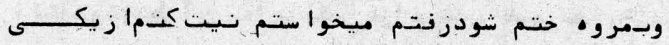

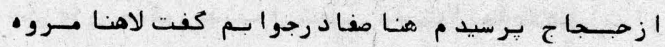

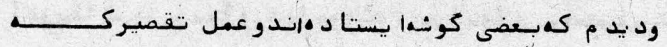

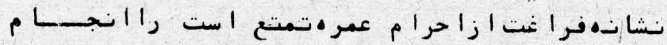

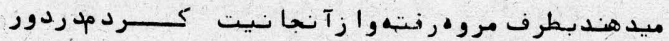

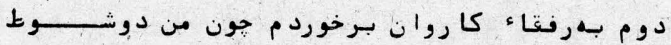

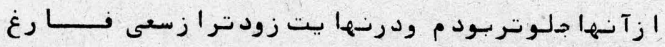

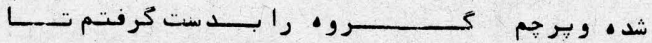

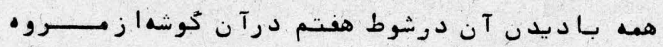

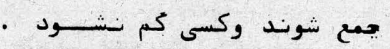

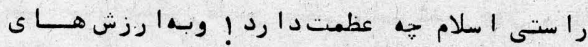

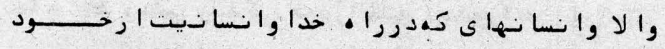

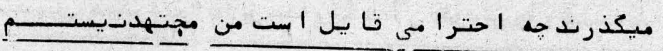

قدرى استرا حت كرد يمم شب بعداز زخوا ندن نماز

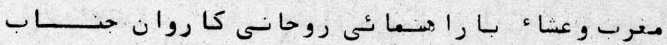
ITT

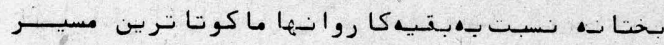

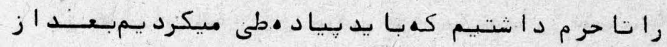

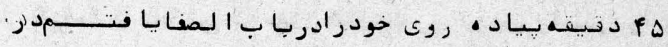

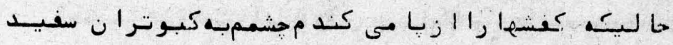

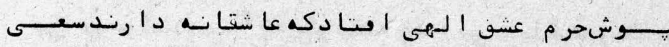

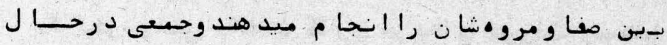

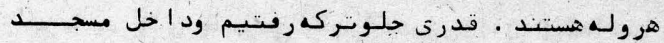

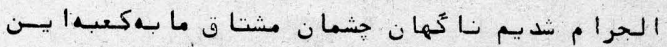

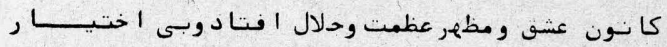

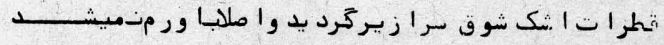

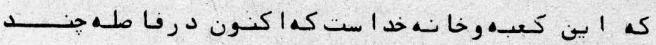

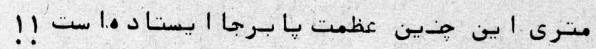

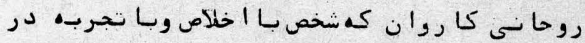

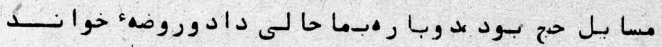

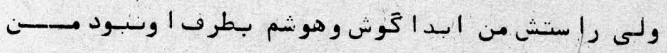

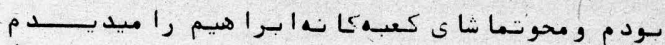

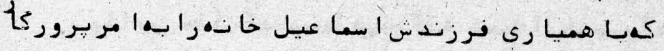

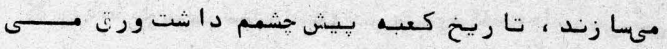

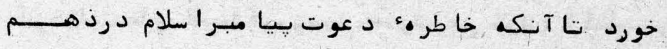

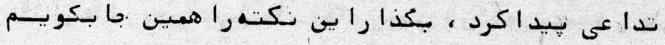

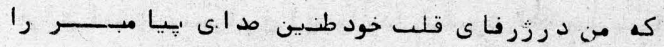

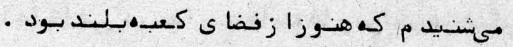

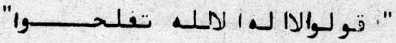

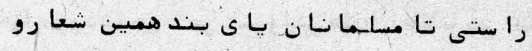

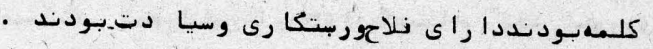

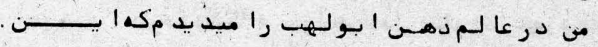

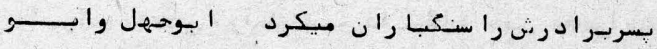

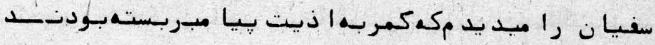

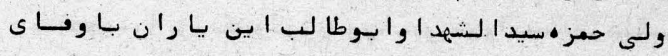

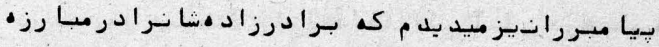

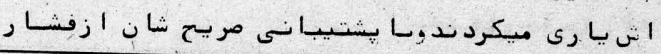


وا كر يك حا حي درحين طوا ف مجـــا سما عيــــل

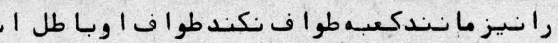

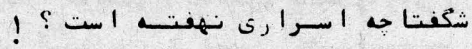

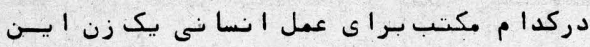

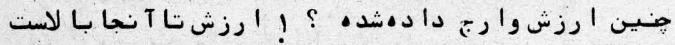

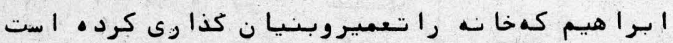

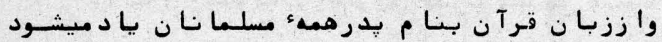

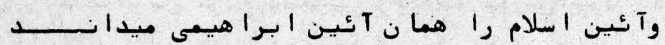

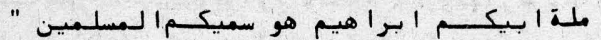

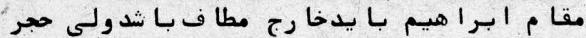

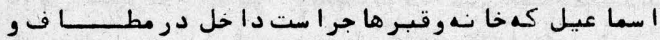

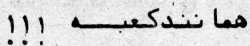

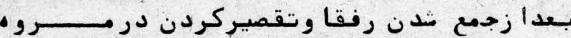

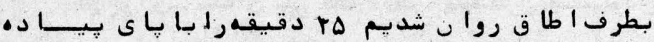

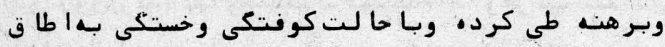

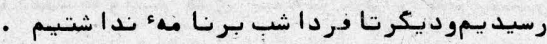

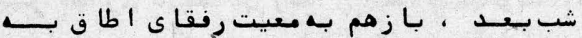

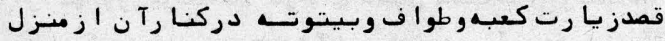

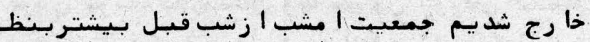

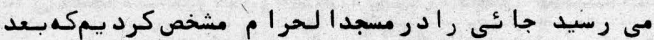

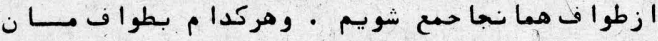

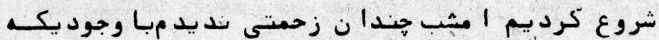

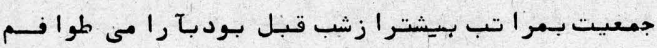

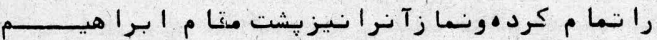

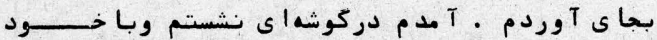

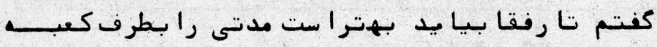

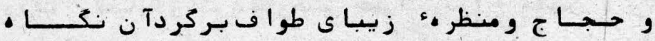

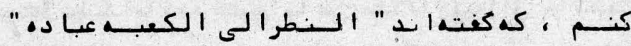

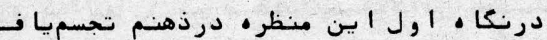

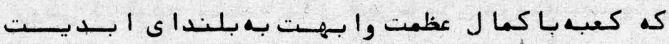

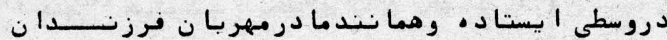

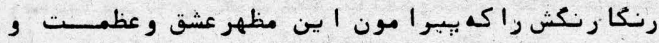

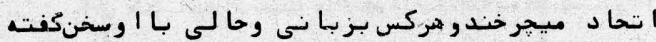

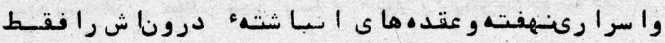

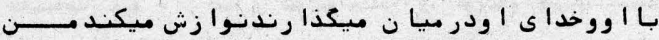

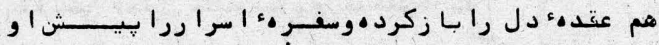

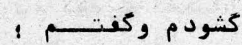

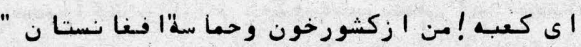

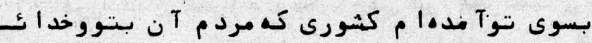

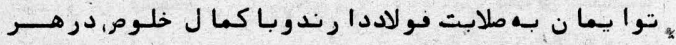

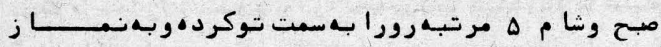

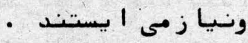

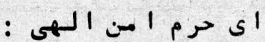

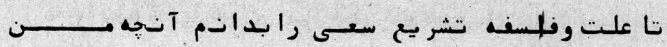

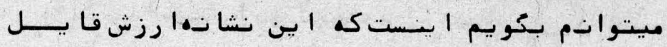

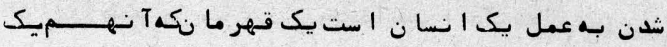

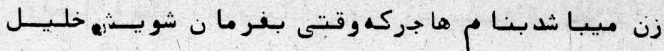

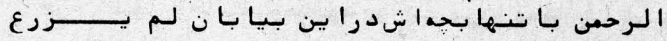

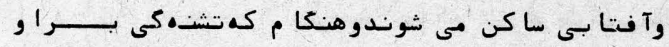

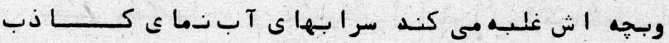

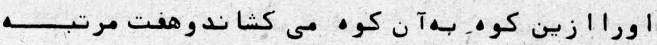

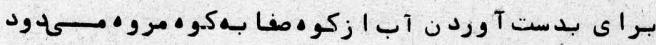

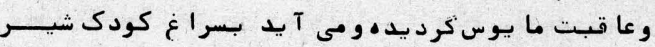

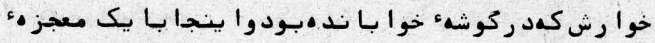

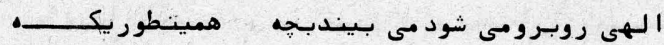

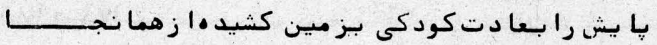

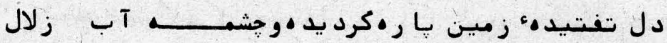

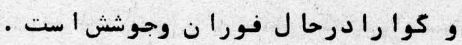

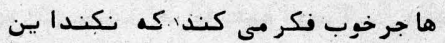

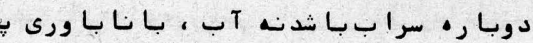

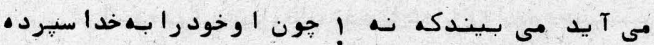

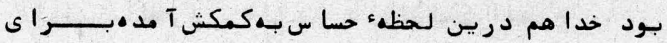

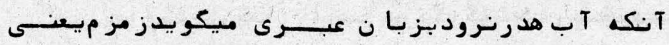

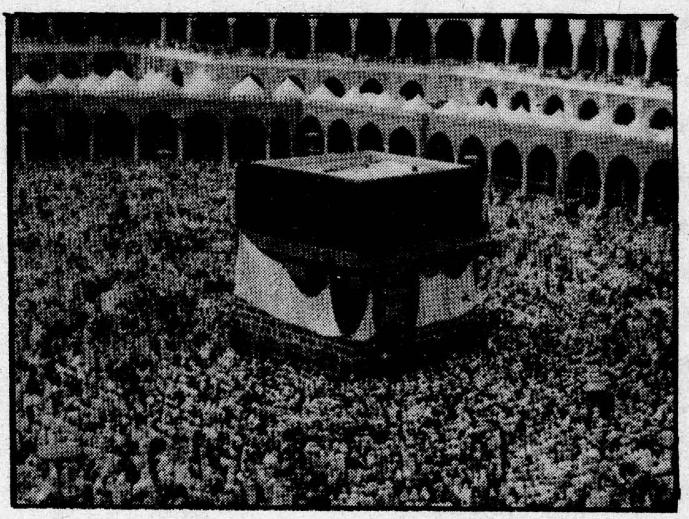

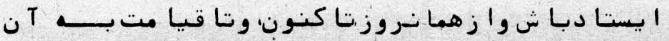

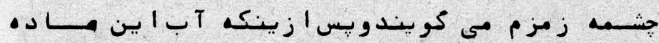

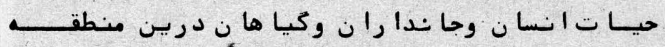

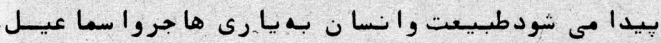

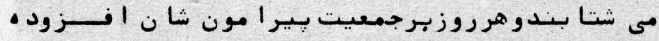

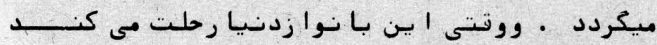

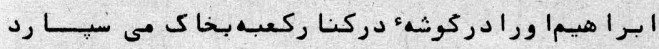

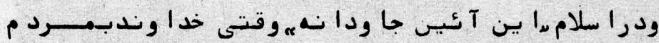

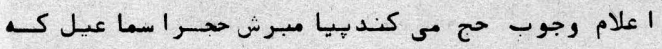

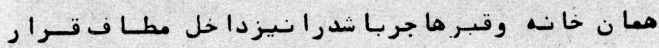




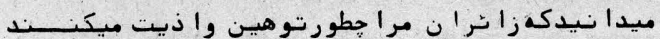

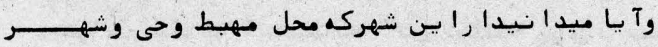

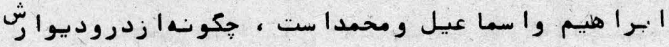

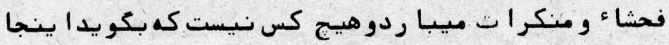

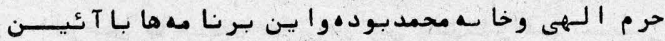

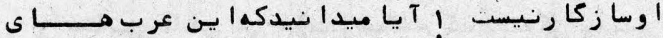

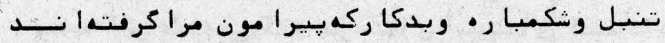

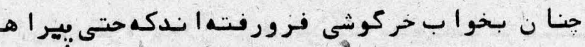

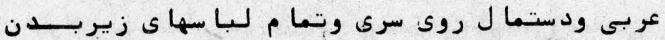

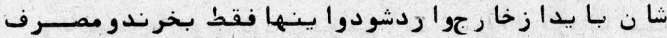

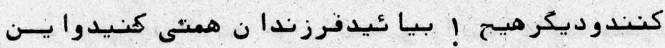

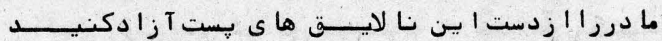

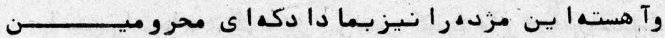

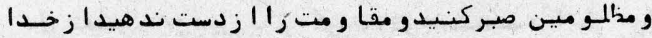

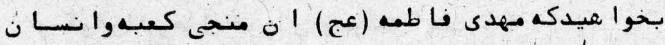

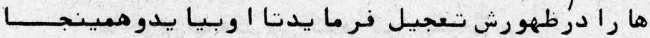

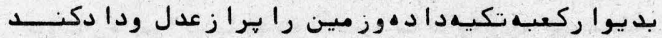

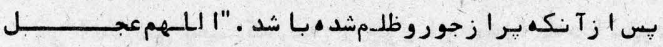

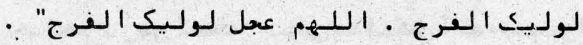

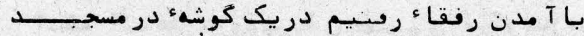

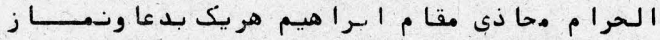

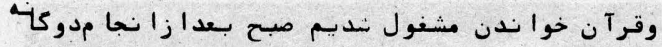

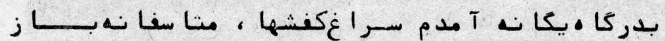

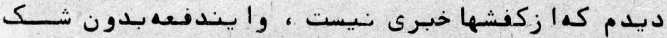

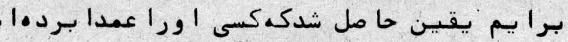

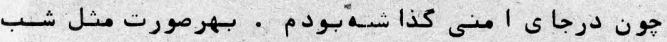

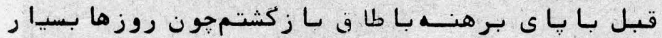

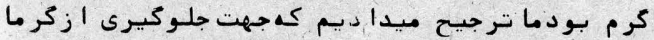

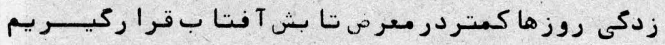

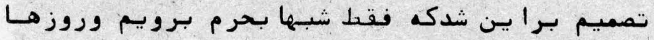
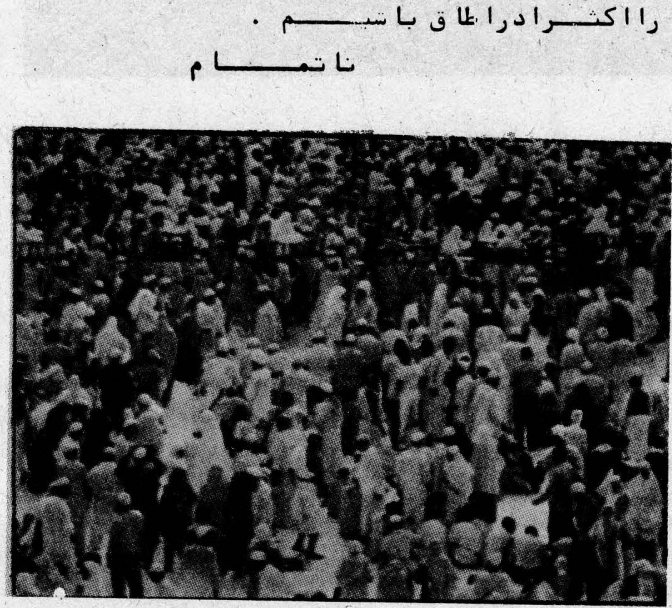

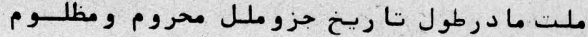

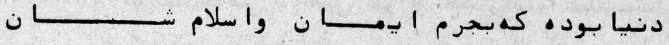

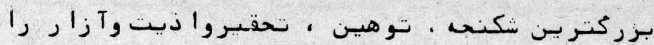

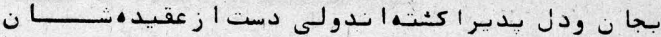

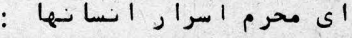

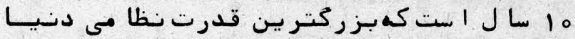

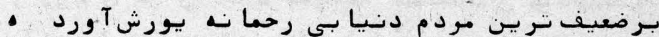

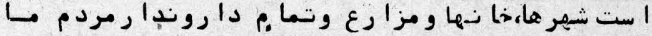

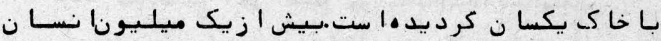

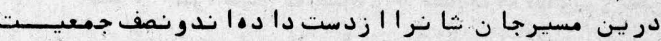

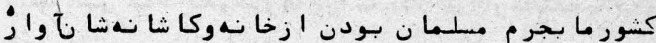

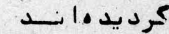

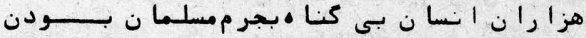

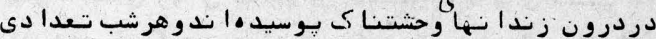

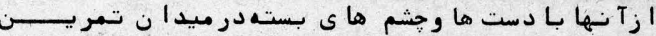

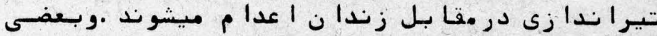

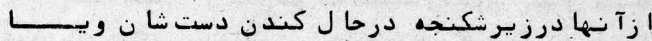

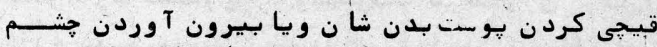

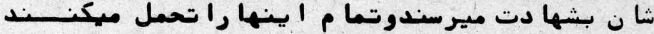

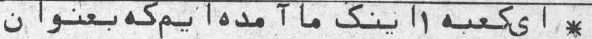

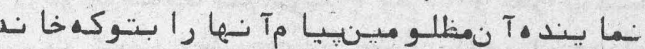

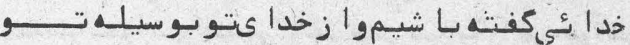

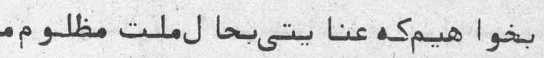
$\longrightarrow$ L 10

الببازلب با زنكرده وحتى حسرت يك آخ كفتن

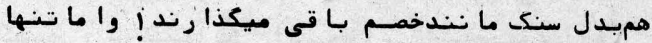

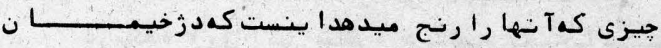

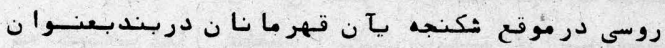

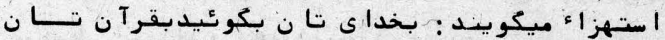

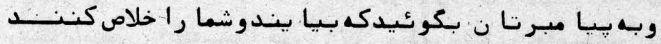

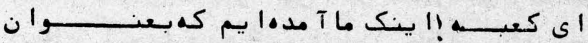

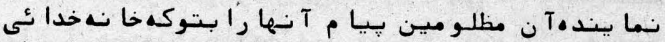

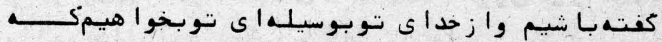

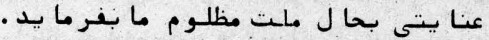

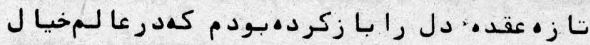

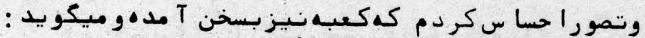

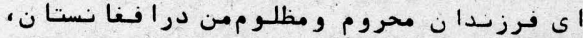

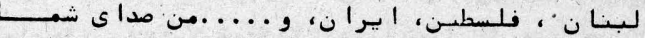

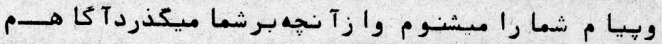

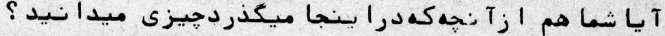

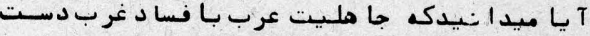

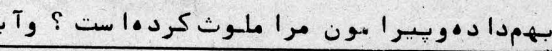




\section{كుำ}

2.

ميدا رند

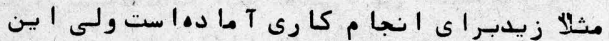

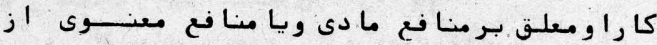

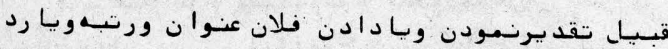

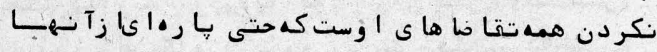

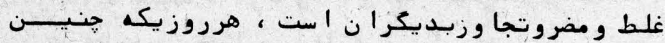

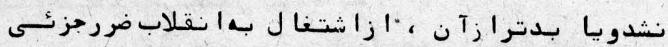

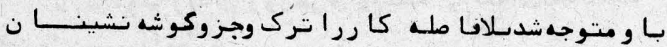

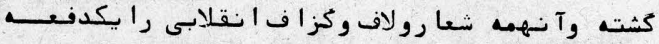

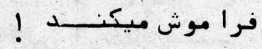

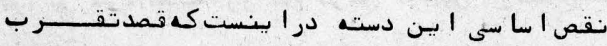

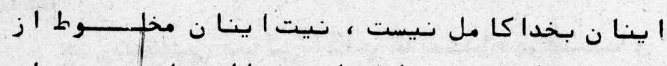

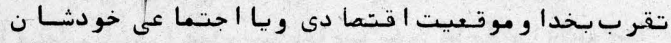

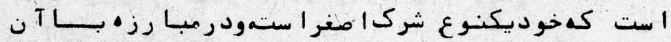

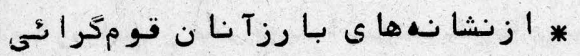

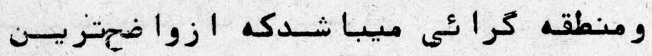

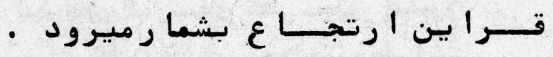

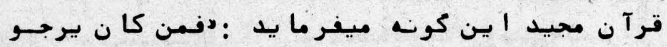

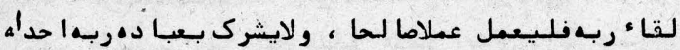

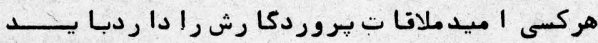

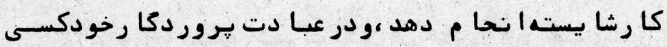

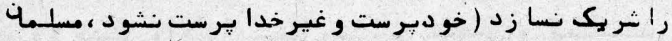

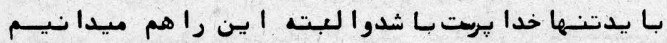

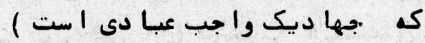

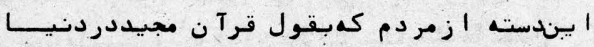

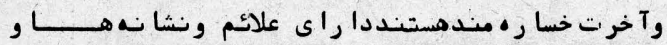

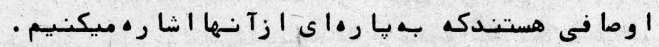

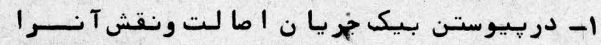

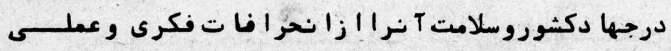

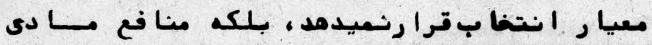

ترآ ن مجيدنا متعهدين را جنين وصف ميفر ما يد :

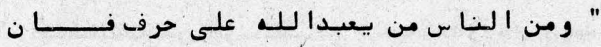

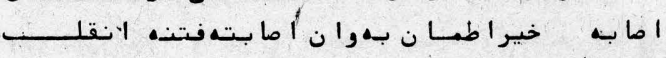

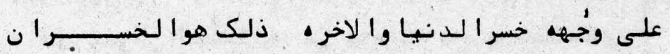

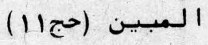

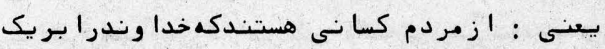

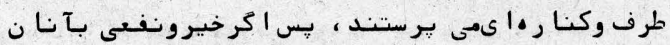

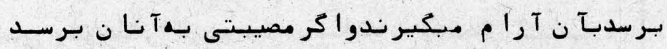

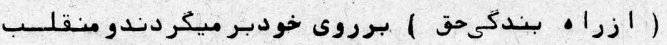

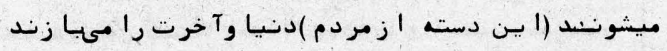

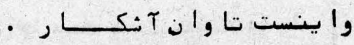

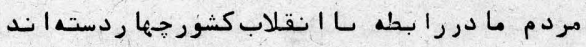

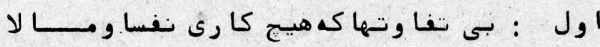

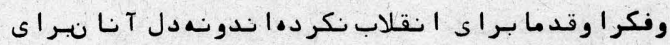

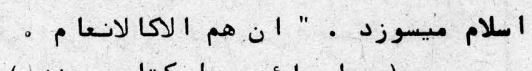

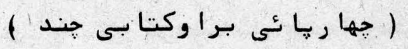

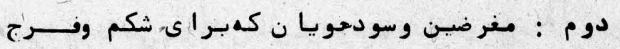

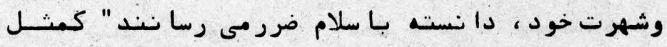

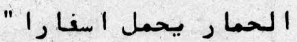

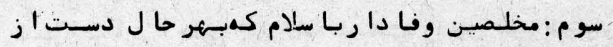

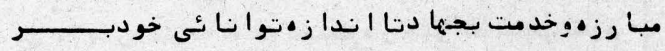

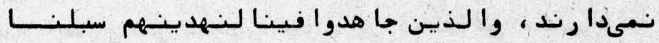

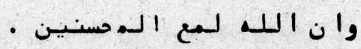

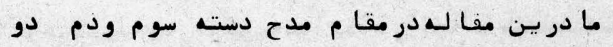

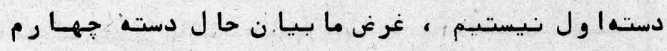

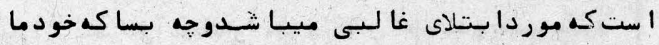

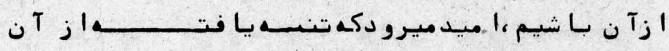

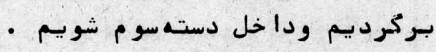

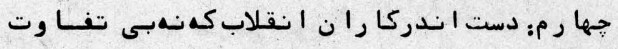

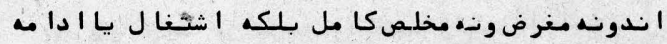

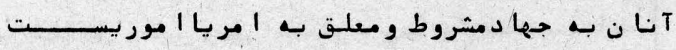

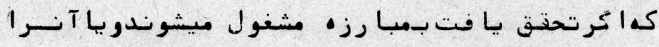

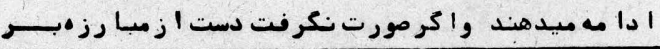




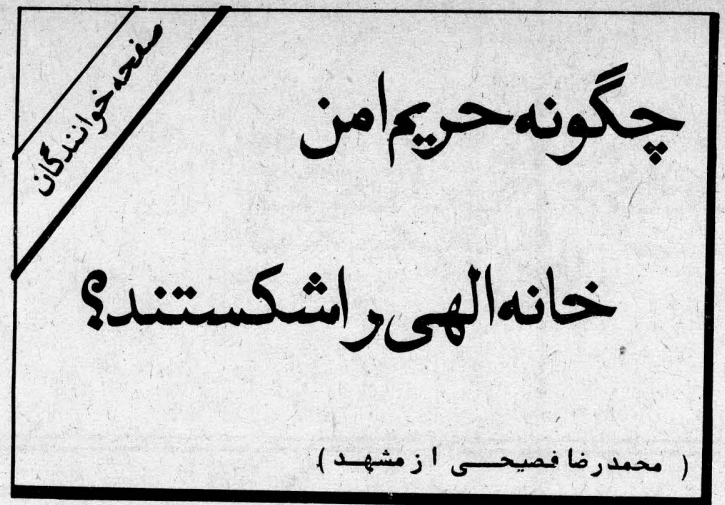

كعبه نخستين קرستشكا هي ا ست كهد رروى زميسن

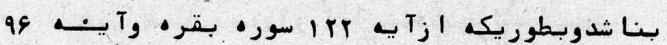

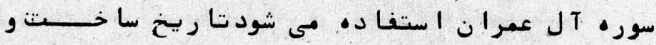

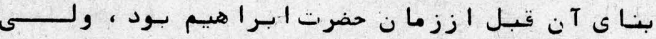

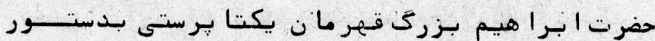

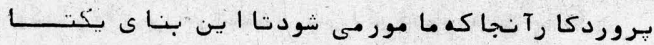

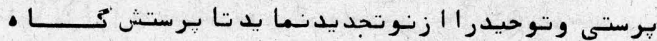

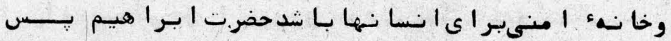

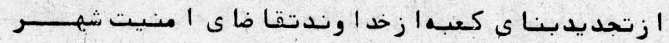

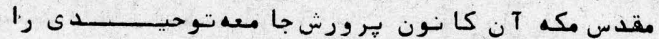

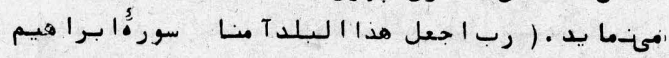

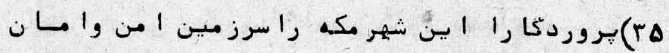

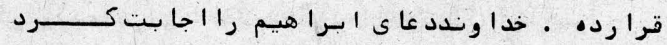
وآن را يك مركز ا من قر اردا د ( و من دخلمكا نآ منا )

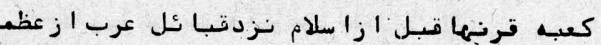

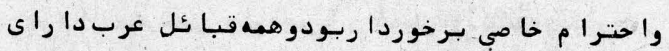

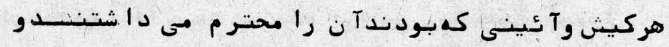

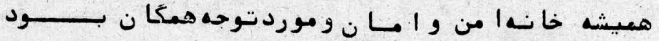

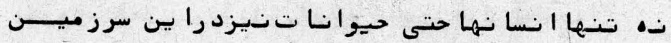

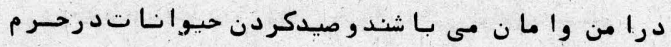

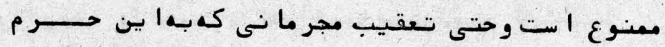

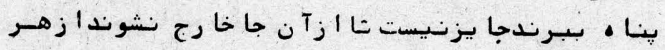

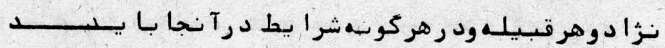

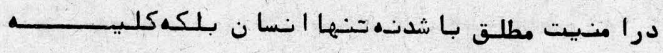

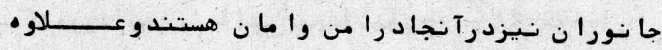

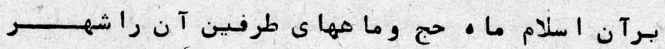

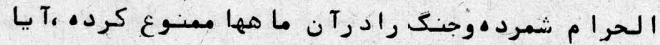

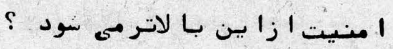

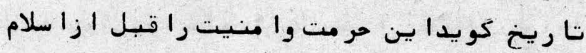

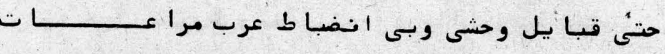

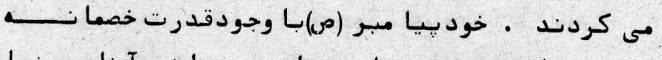

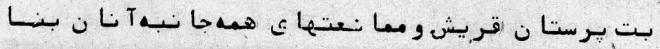

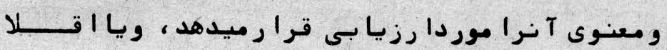

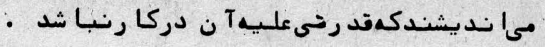

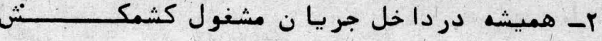

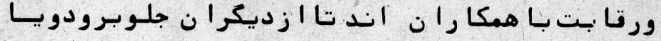

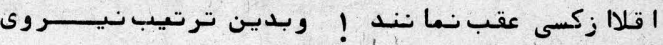

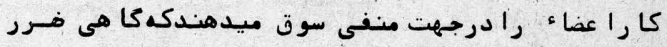

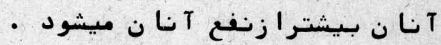

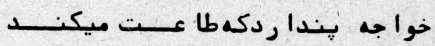

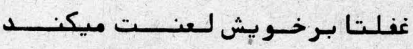

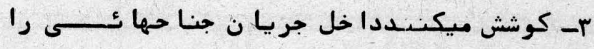

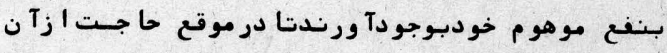

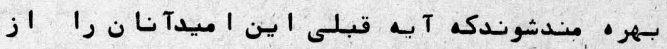

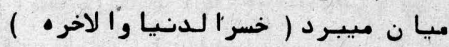

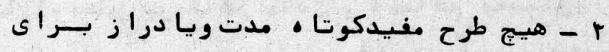

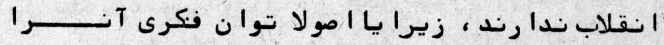

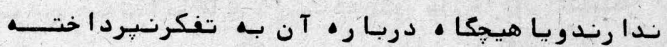

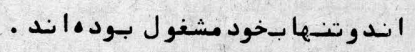

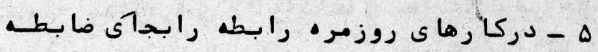

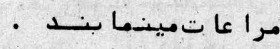

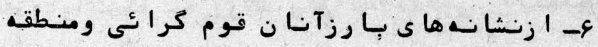

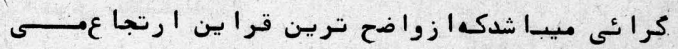
بـا شد بكر

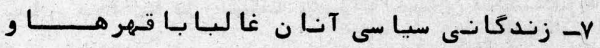

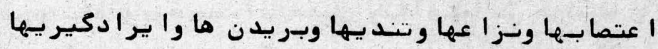

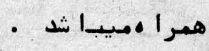

1- موضعكيرى أ ينا ن درمقا بـل تعددكرورمىمثبت

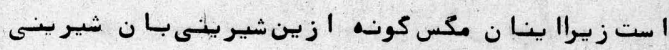

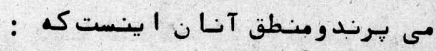

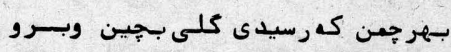

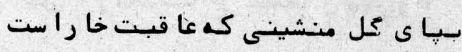

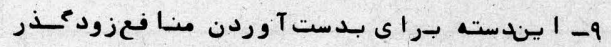

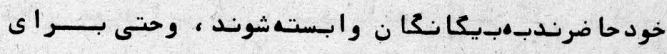

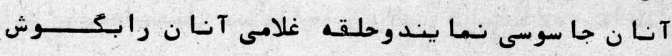
- بيا وريزند

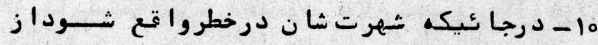

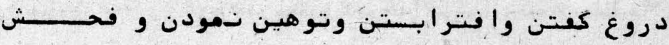

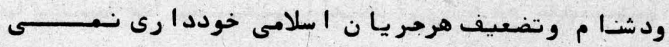

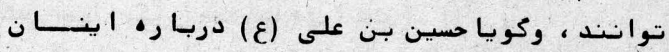

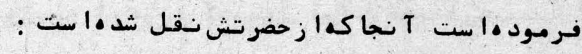

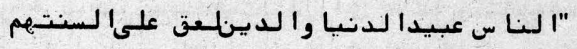

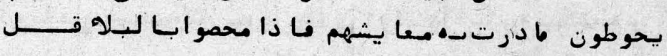

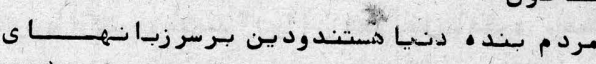

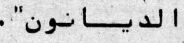

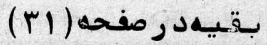




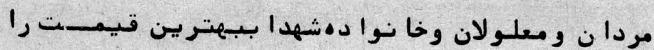

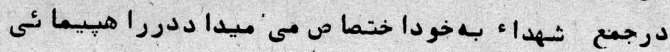

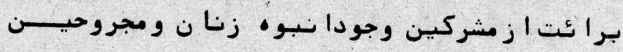

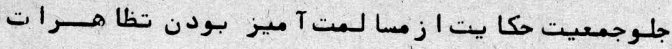

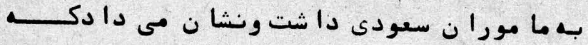

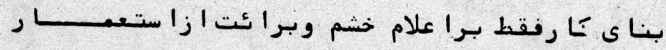

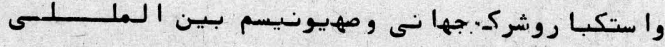

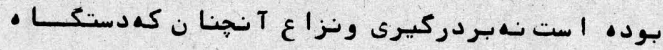

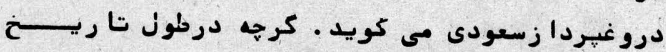

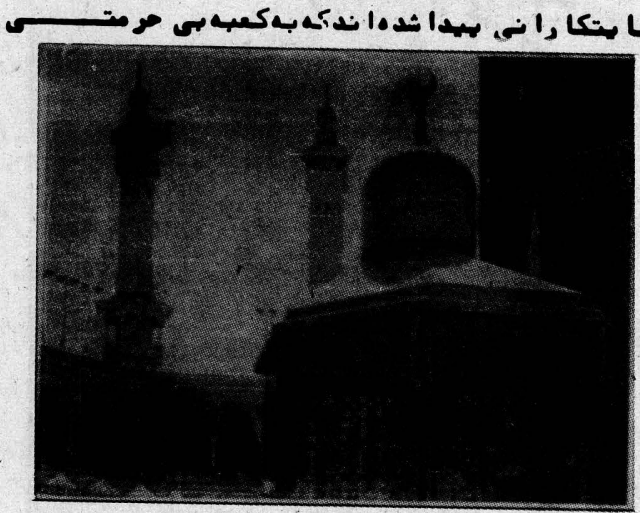

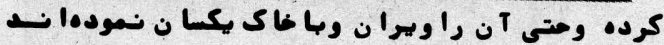

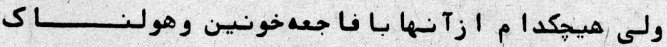

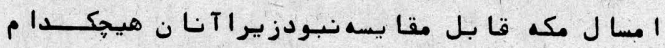

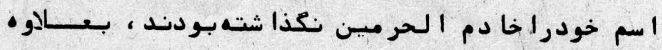

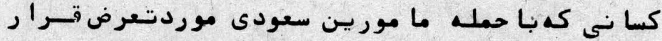

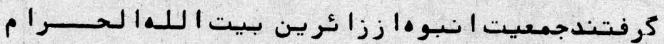

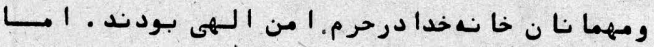

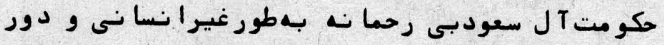

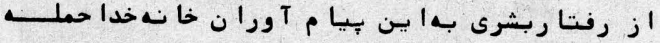

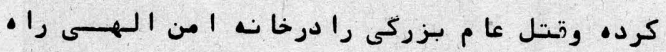
انداخت .

بقتيم/ زمفه (ro)

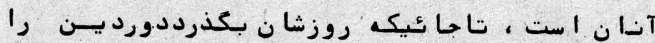

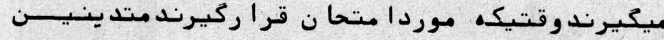

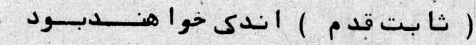

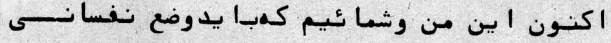

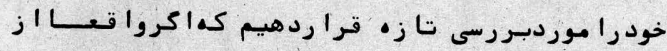

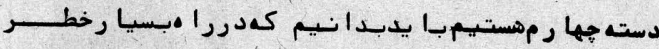

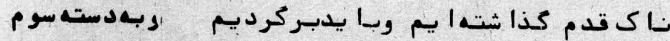

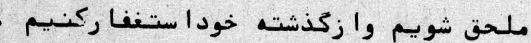

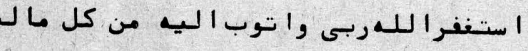

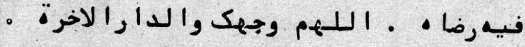

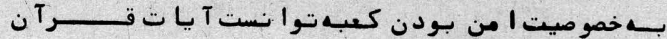

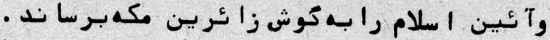

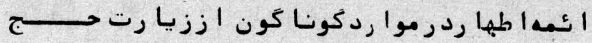

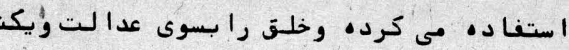

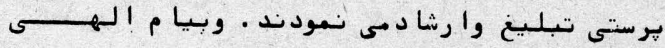

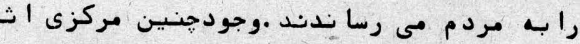

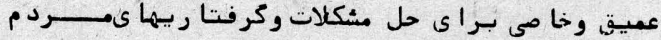

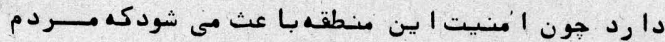

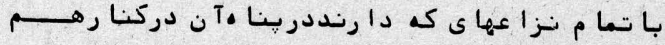

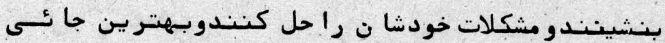

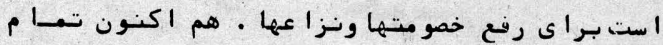

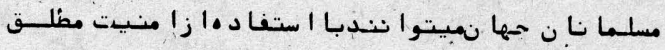

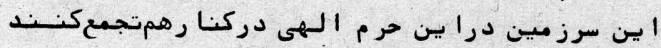

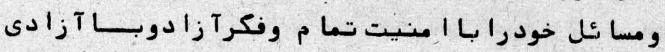

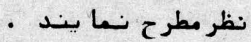

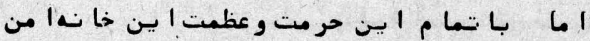

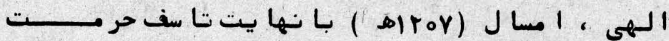

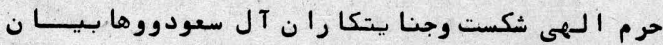

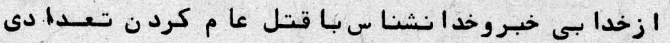

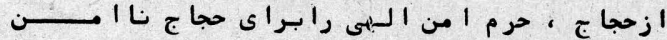

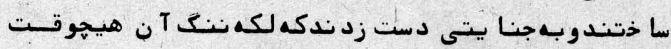

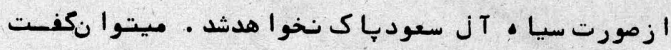

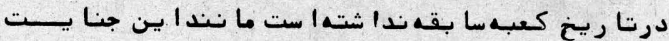

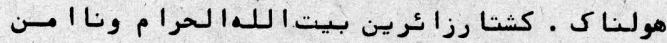

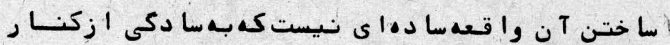

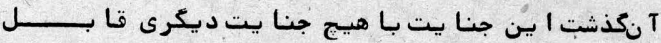

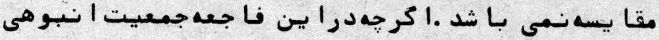

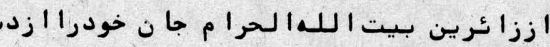

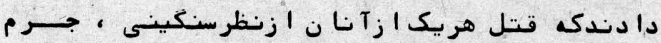

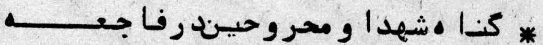

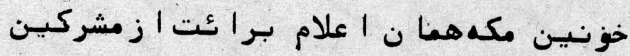

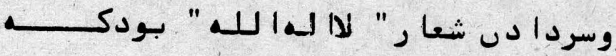

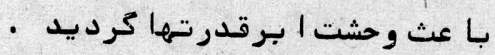

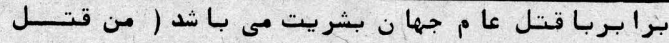

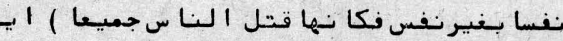

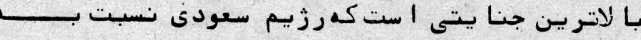

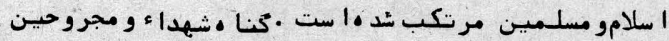

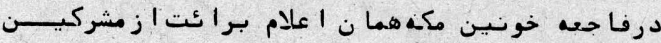

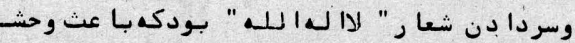

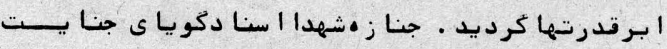

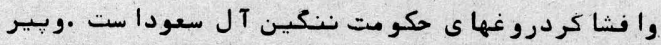




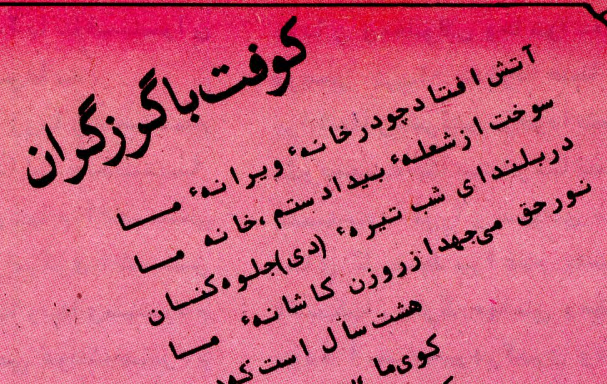

wese

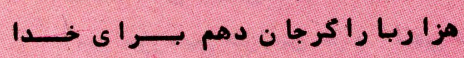

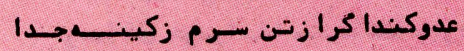

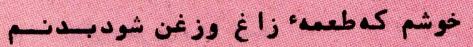

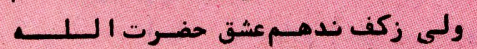
गु) .

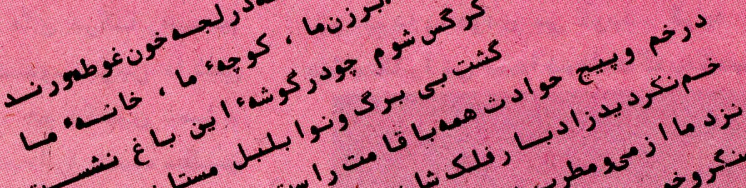
(1)

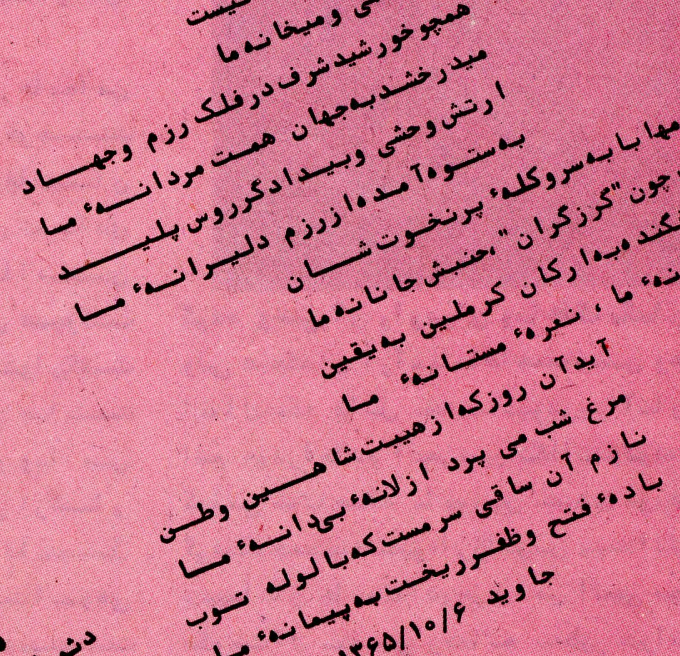

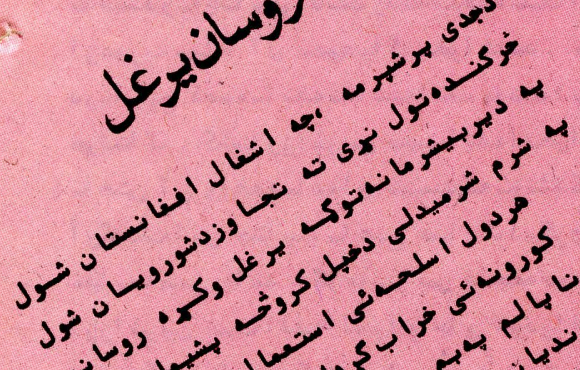

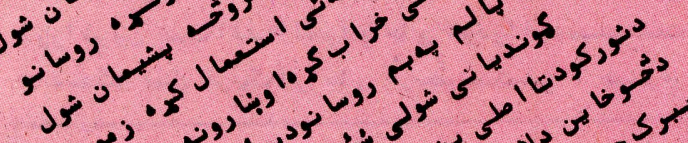

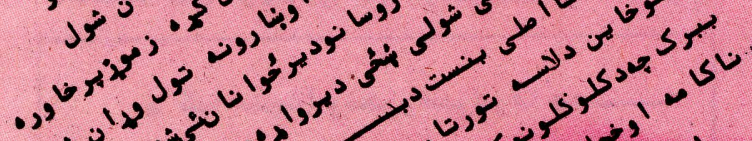

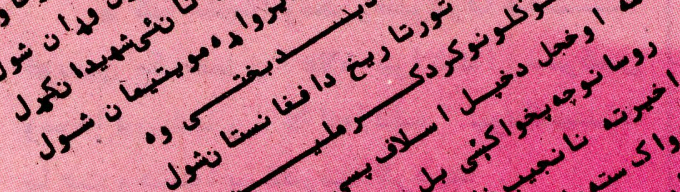

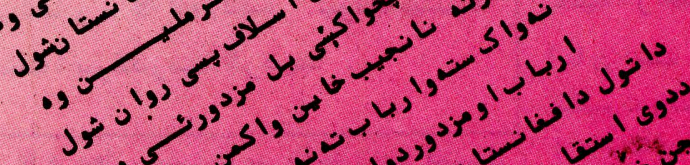

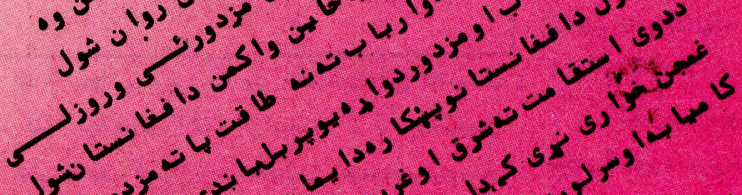

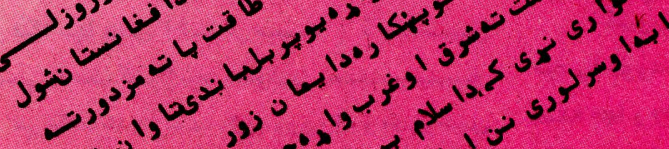

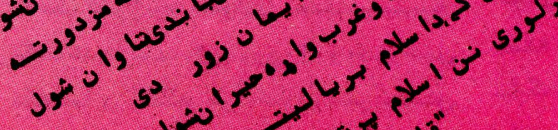

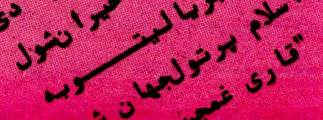

$$
\begin{aligned}
& 3 \%
\end{aligned}
$$




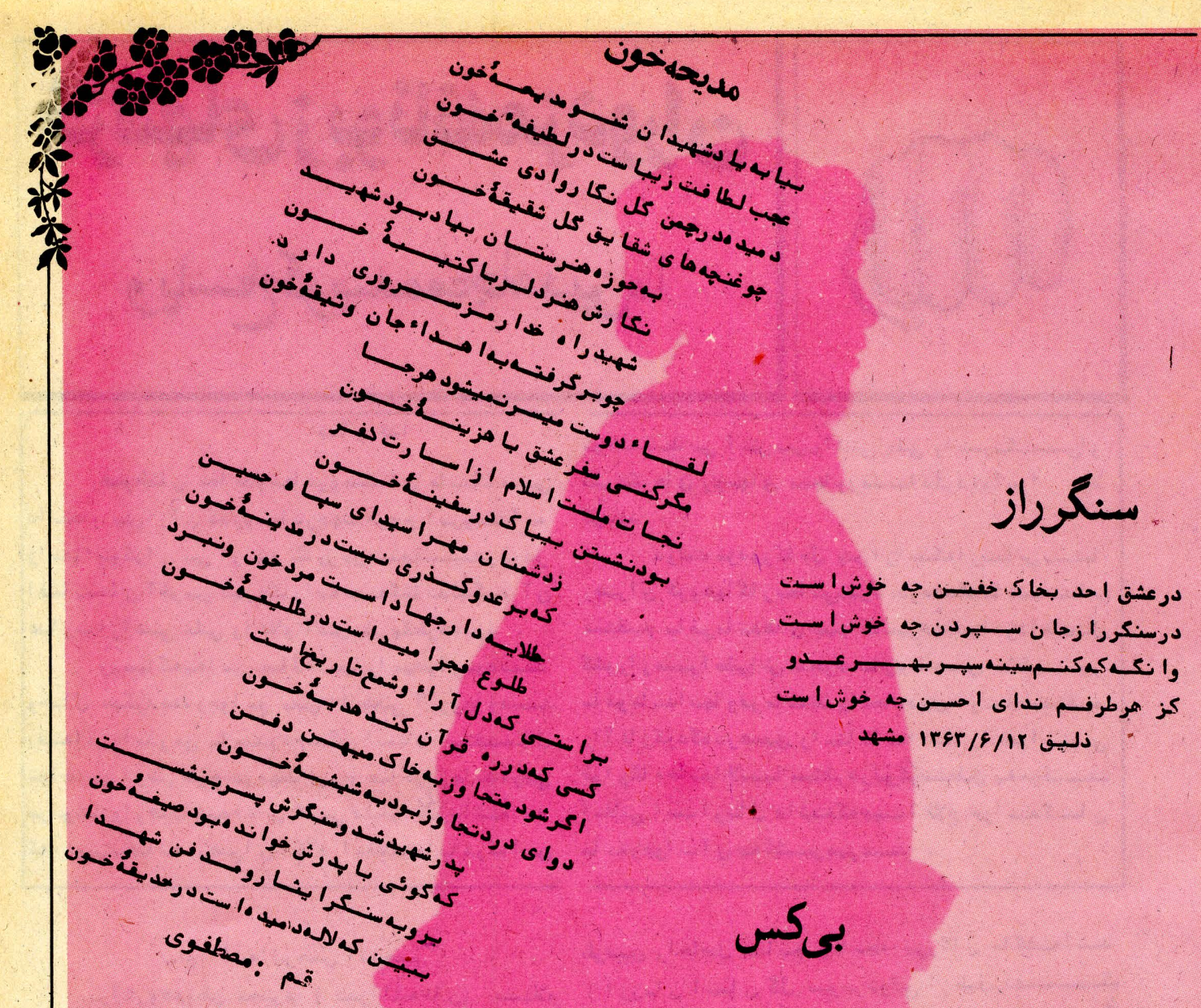

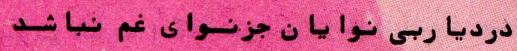

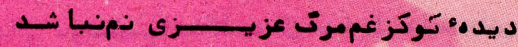

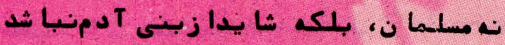

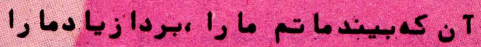

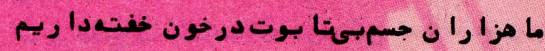

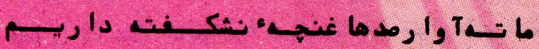

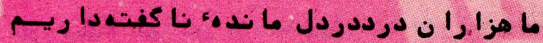

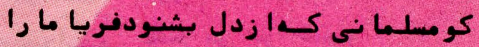

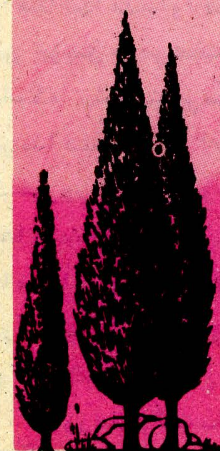

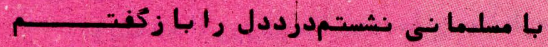

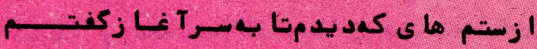

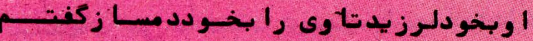

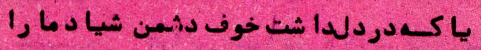

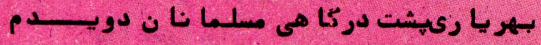

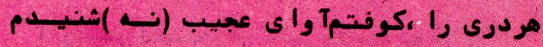

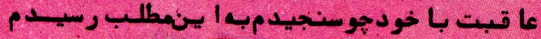

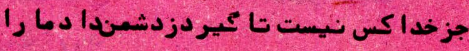

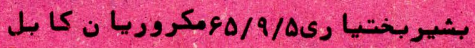




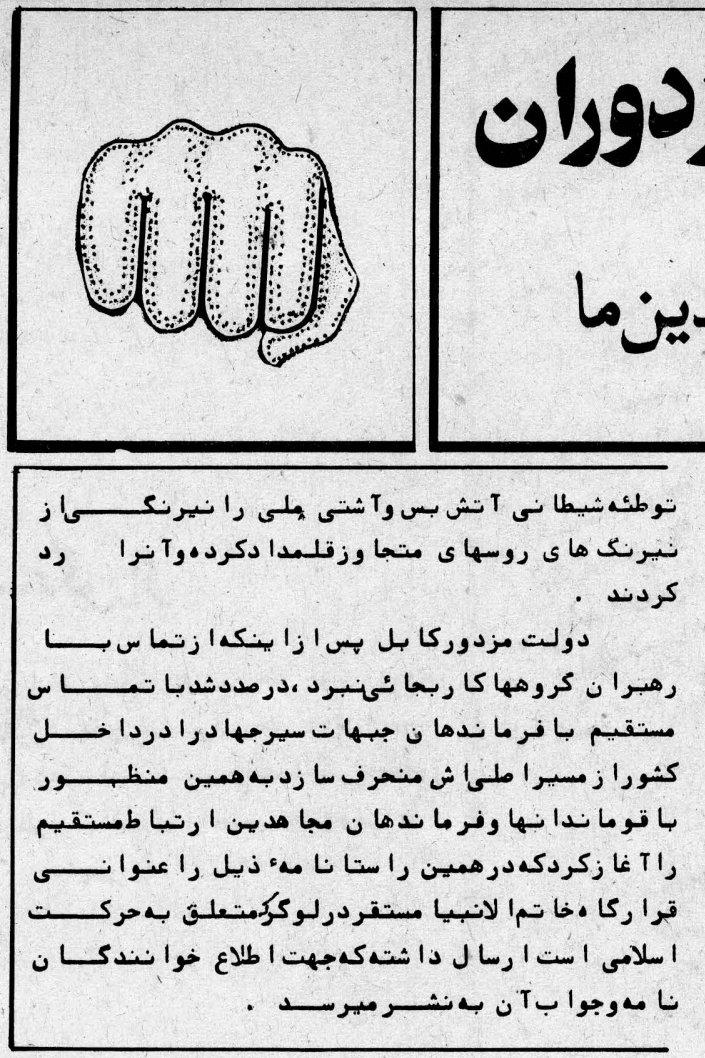

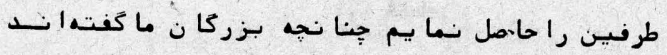

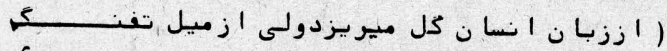

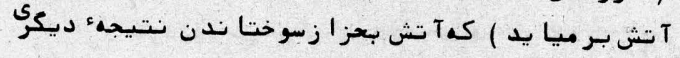

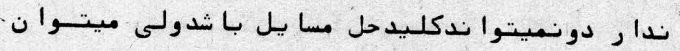

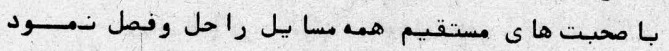

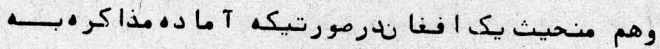

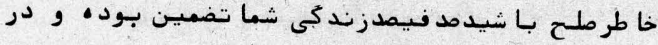

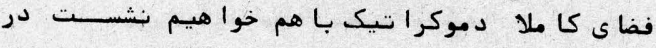

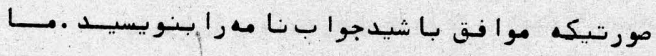

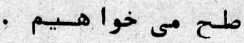

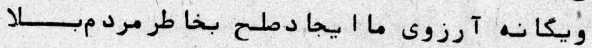

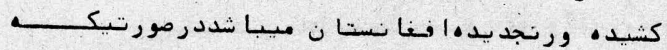

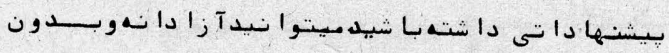

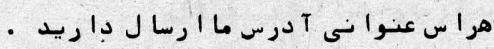

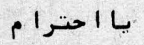

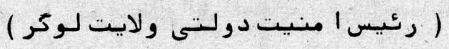

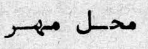

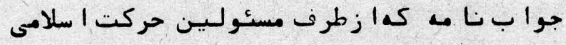

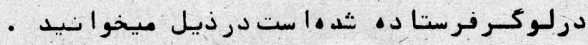

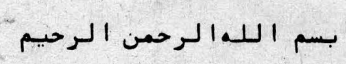

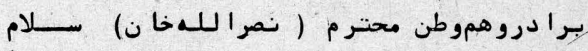

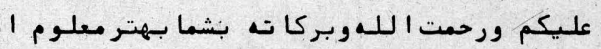

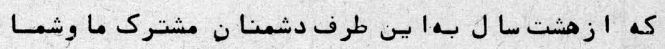

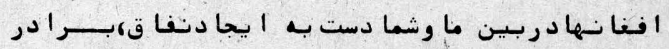

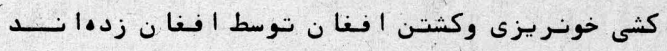

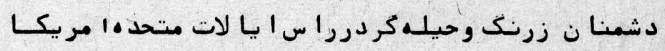

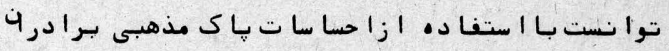

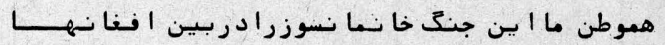

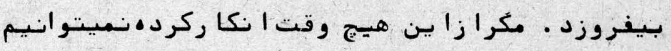

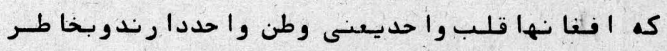

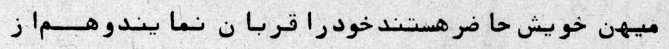

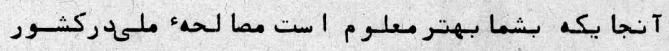

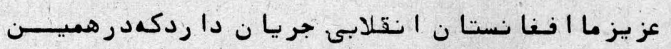

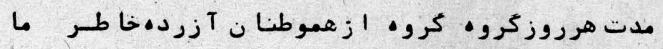

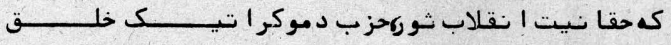

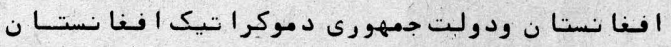

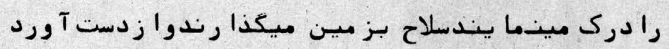

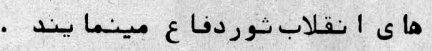

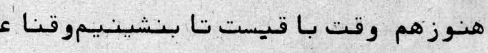




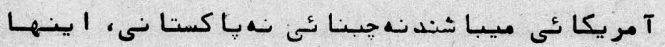

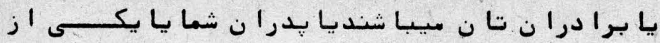

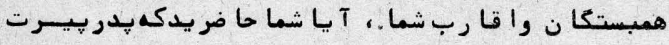

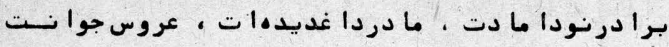

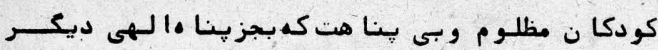

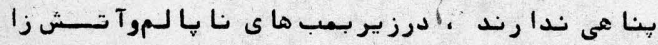

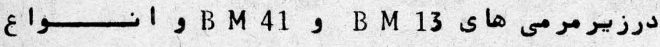

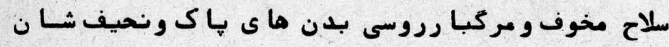

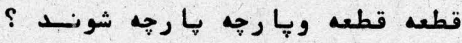

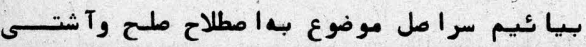

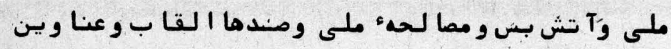

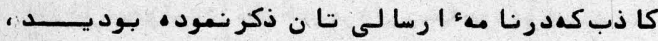

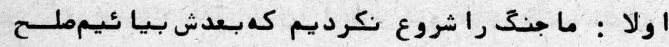

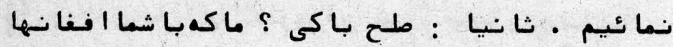

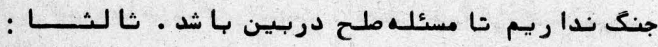

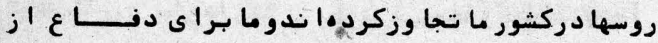

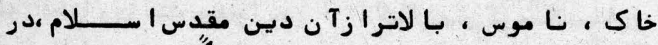

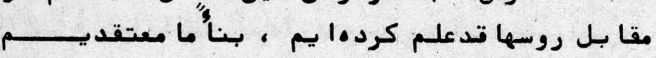

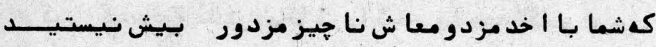

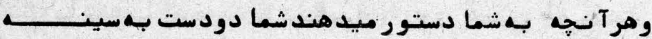

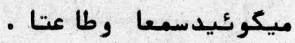

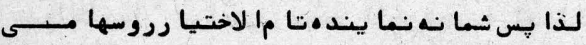

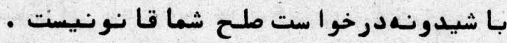

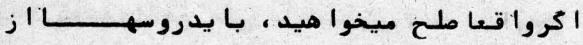

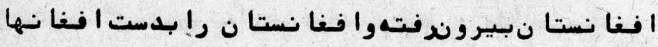

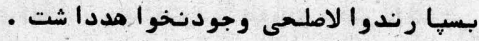

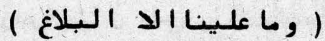

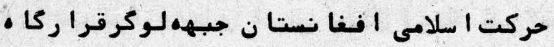

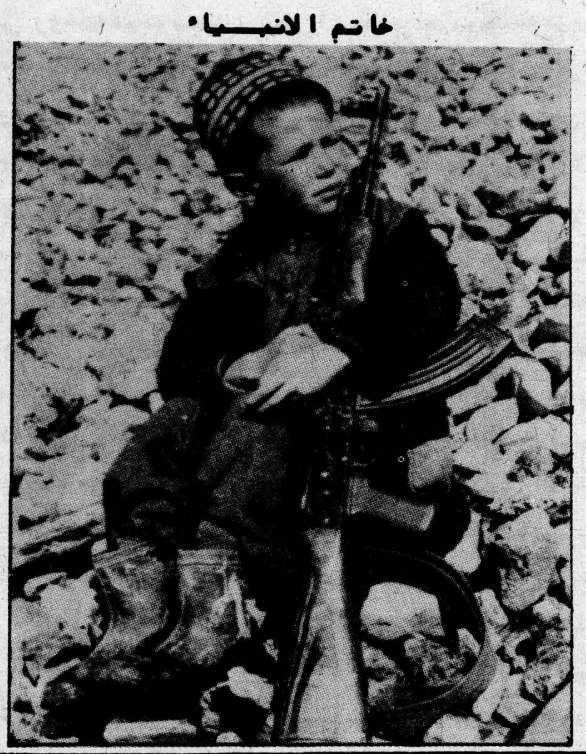

محمد رسول اللـهو الـذينمعها شداء على للكفا روحماء (قر ن ن كر يمبم ) بينهم" مهدر

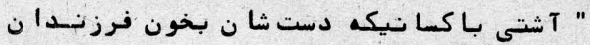

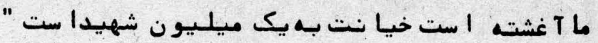

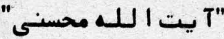

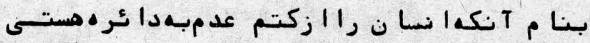

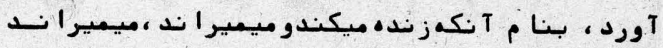
وزنده ميكند . ورن

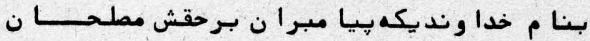

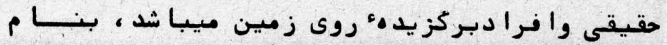

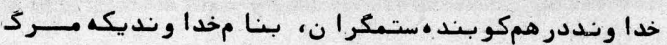

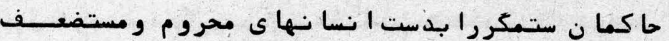

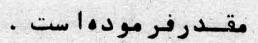

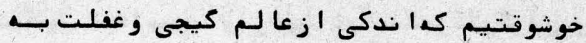

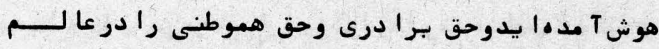

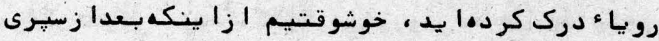

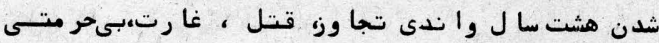

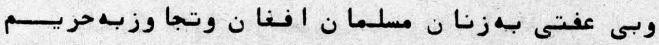

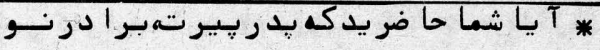

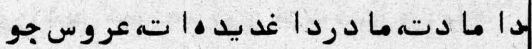

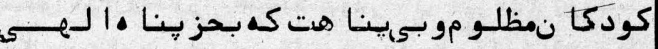

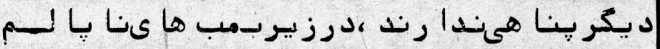

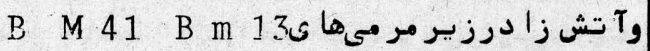

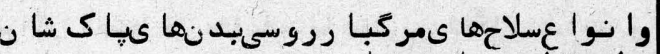

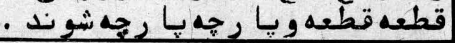

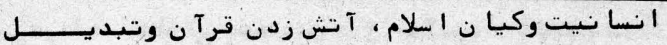

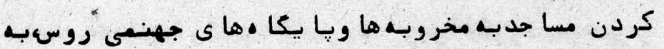

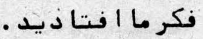

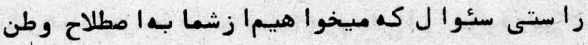

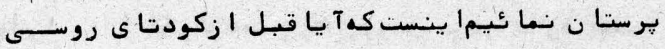

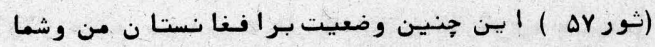

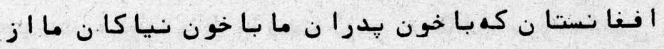

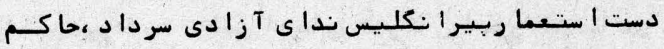

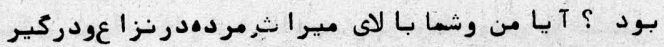

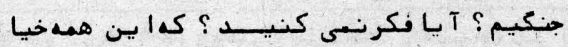

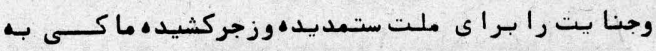

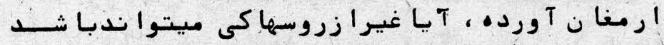

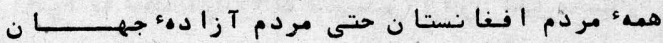

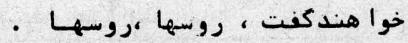

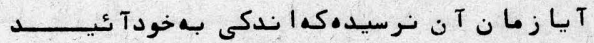

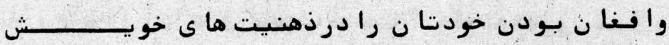

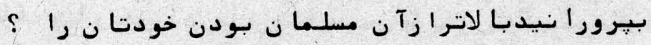

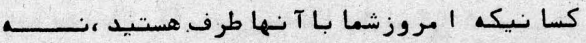




\section{يروزتلاريإقربانىسرانسوسياليسم}

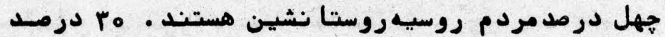

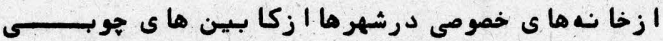

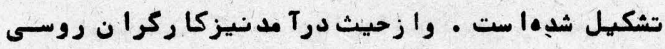

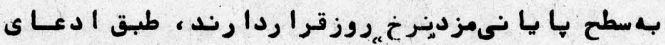

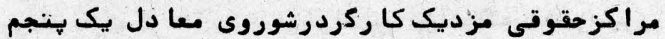
حقوق كا ركرا مر يكا مئيست.

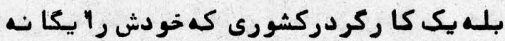

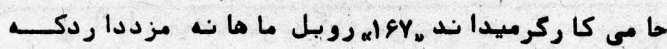

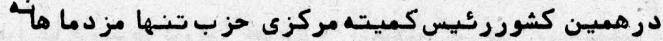

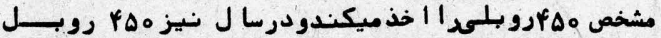

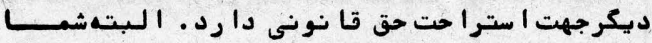

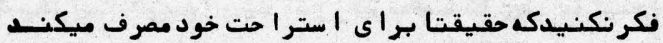

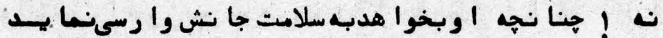

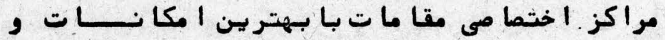

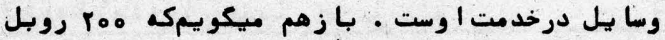

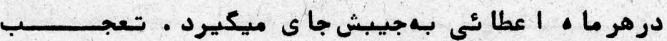

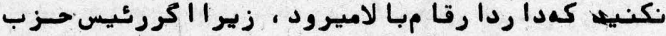

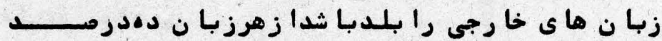

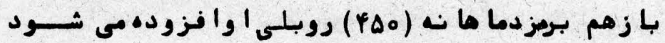

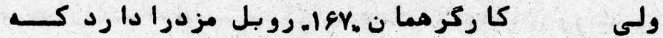

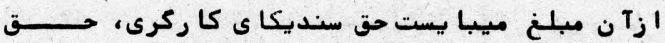

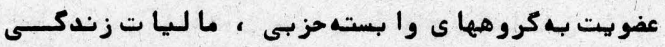

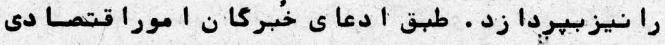

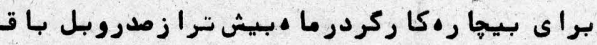

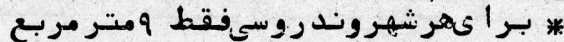

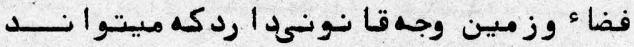

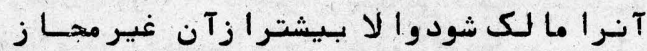

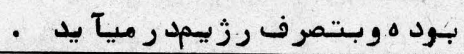

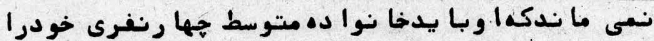

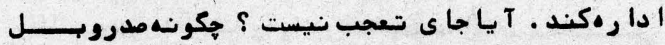

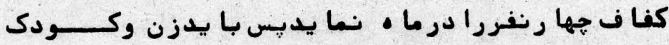

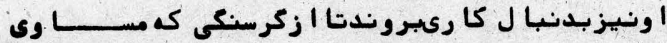

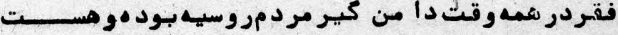

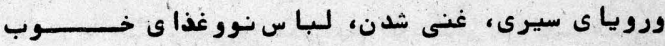

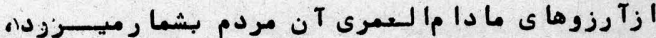

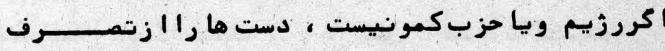

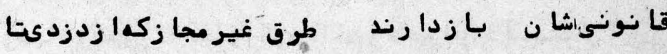

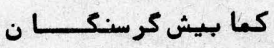
رشور هخوا رىا ست ميتوا ندان

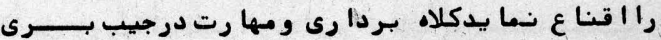

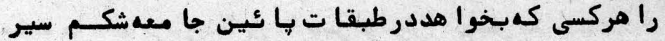

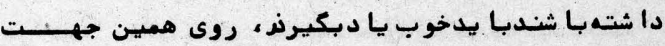

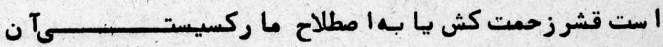

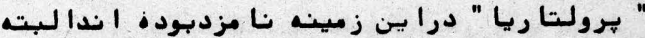

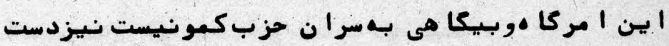

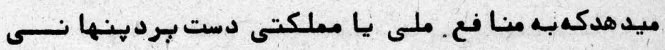

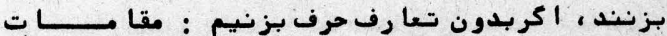

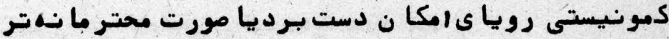

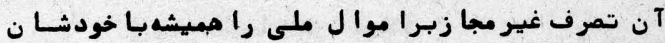

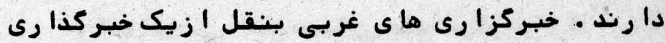

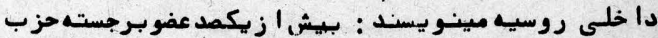

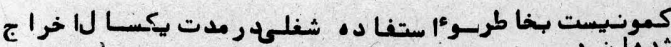

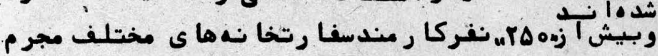

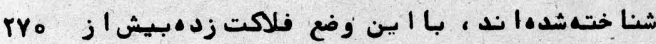

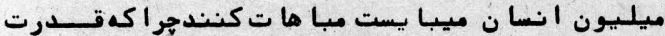

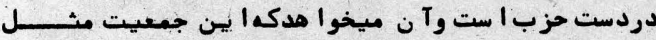

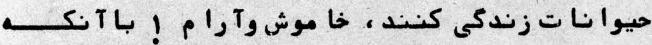

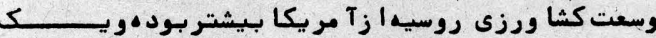

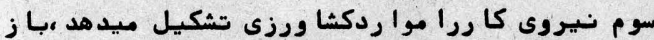

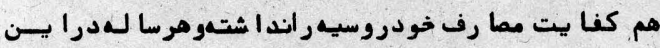

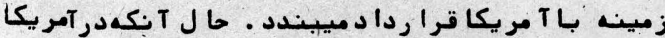

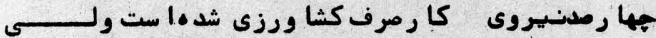

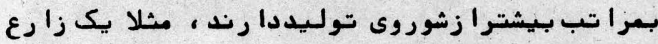

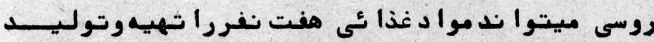

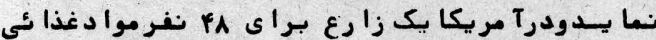

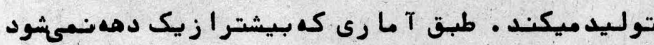




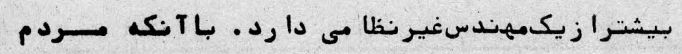

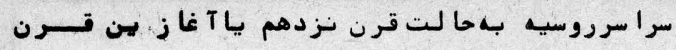

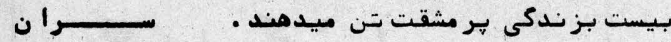

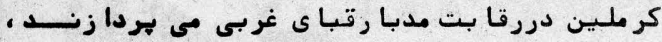

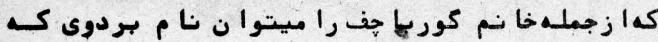

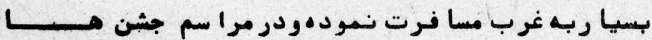
* خانم كوربا هف بـا دا ردكه مـدا.ل

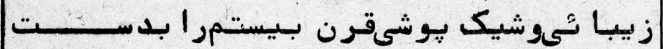

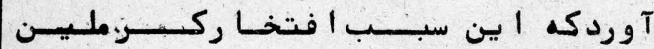

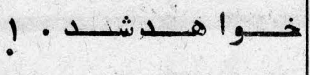

ونما يش ها شركت ميكند ، زبا ن زدرفقاى غربى شـده

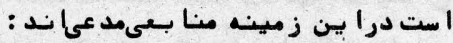

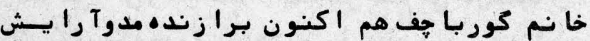

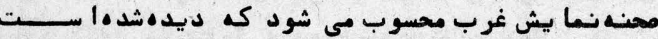

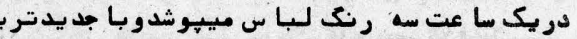

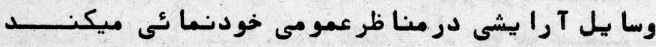

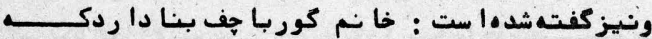

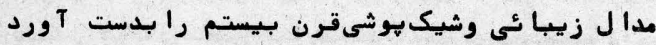

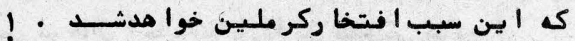

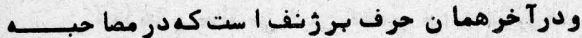

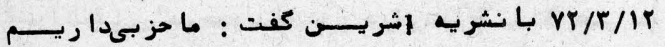

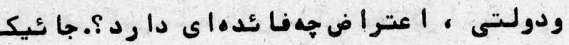

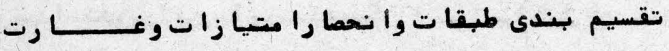

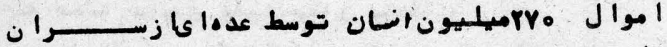

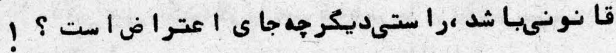

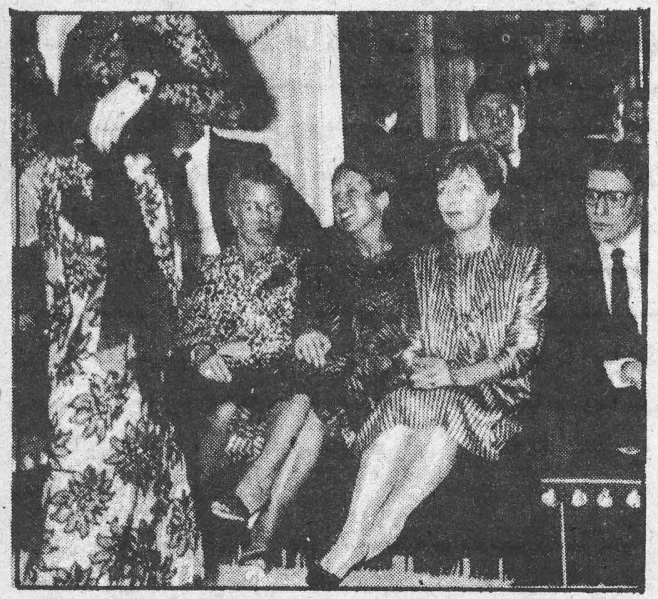

"ر يسا كوباجف)"درنمايثكاهمدباريس.

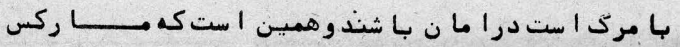

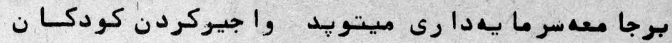

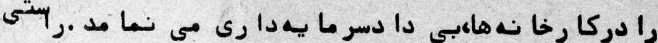

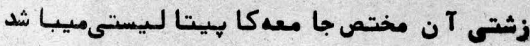

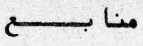

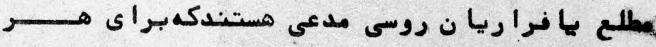

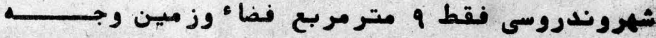

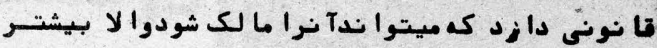

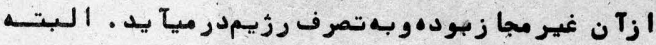

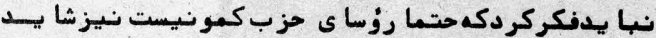

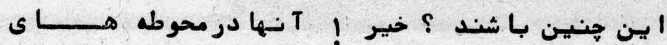

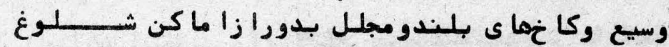

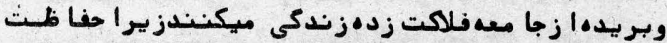

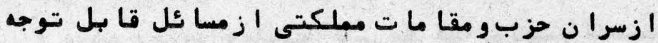

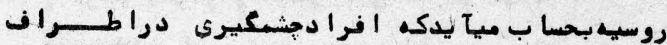

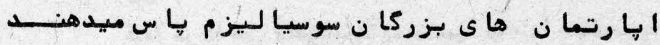

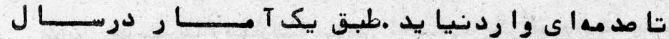
lqYA

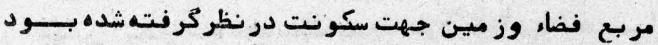

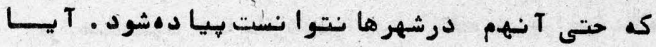

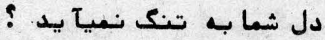

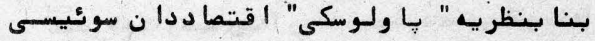

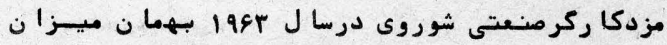

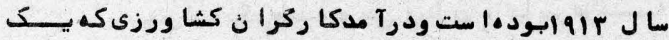

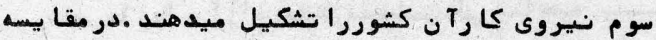

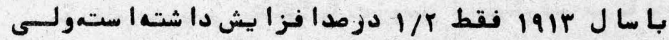

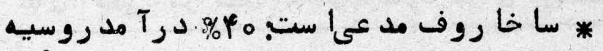

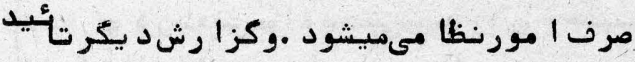

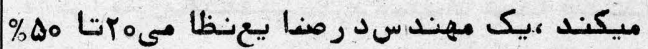

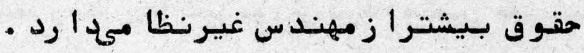

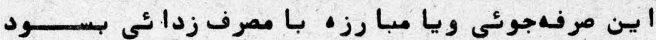

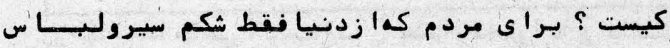

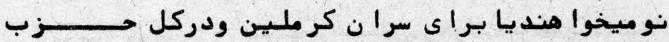

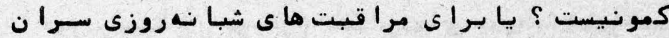

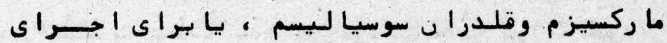

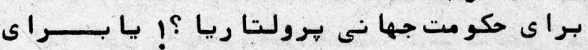

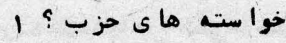

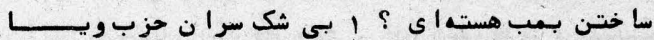

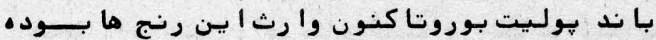

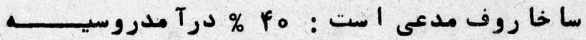

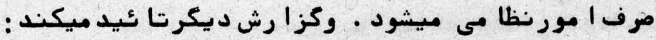

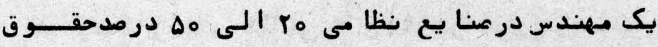



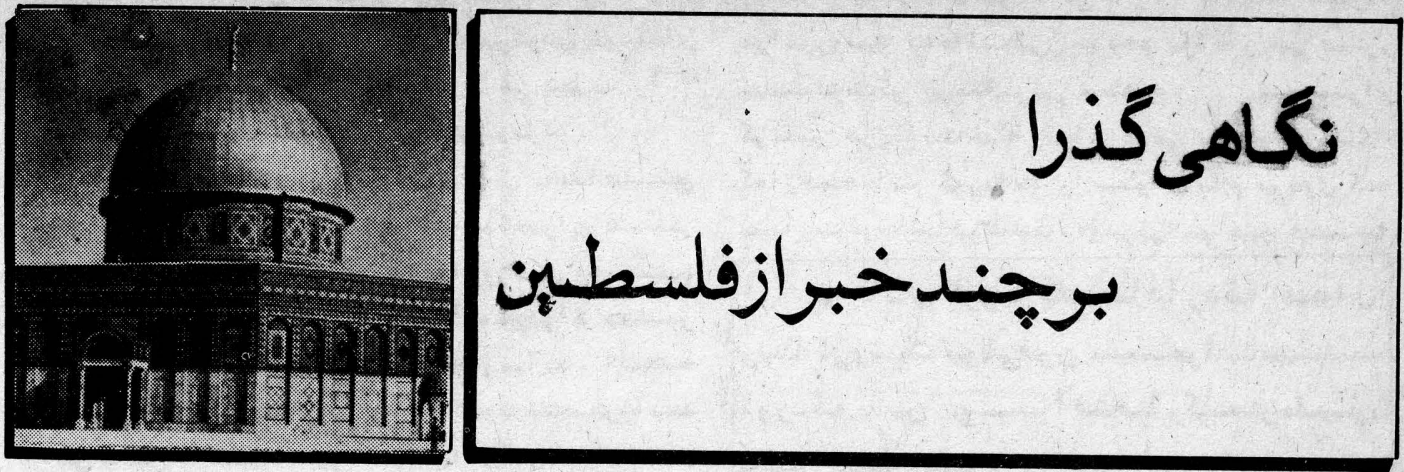

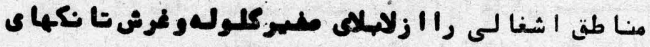

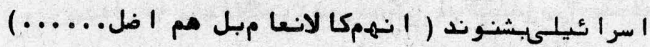

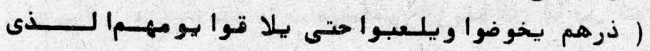

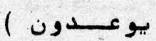

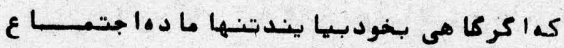

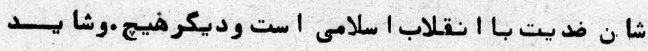

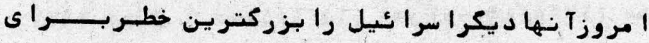

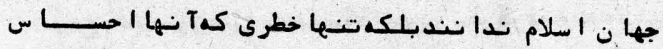

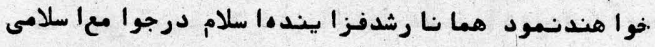

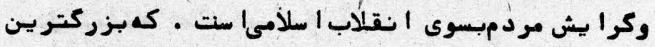

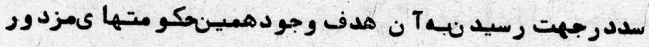

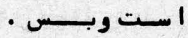

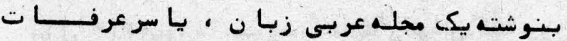

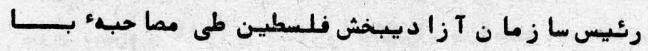

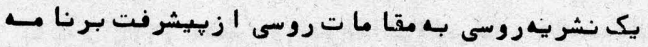

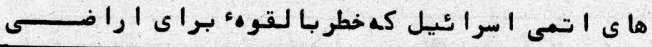

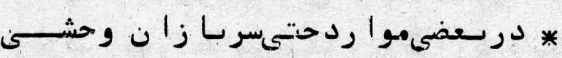

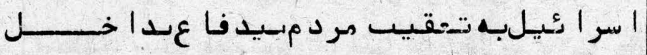

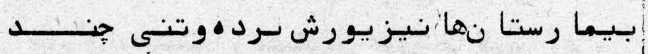

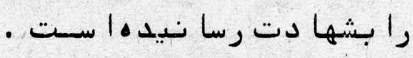

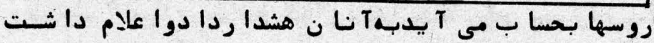

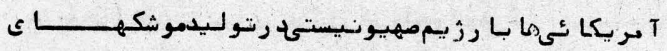

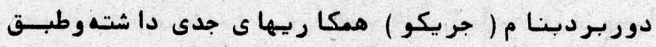

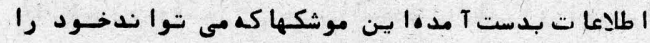

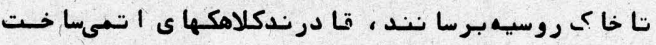

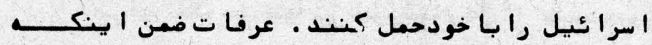

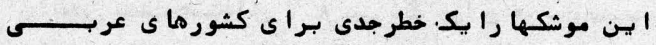

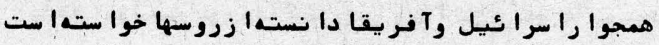

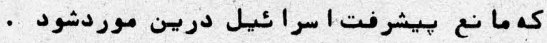

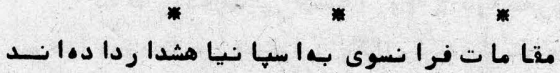

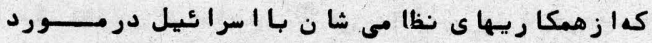

قواى أشغال لكر رزيمصهيونيستى در منطقها شغنال ل

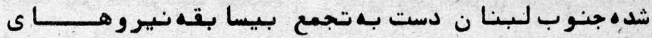

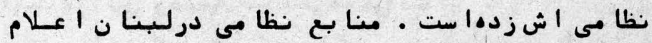

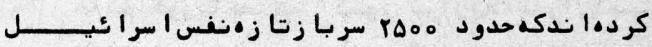

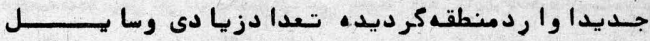

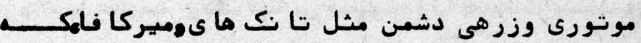

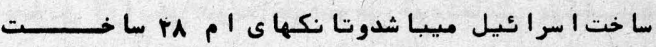

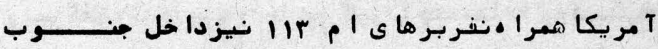

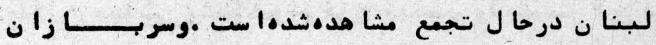

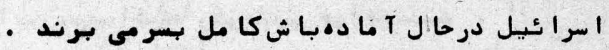

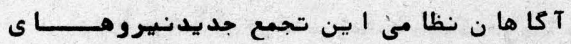

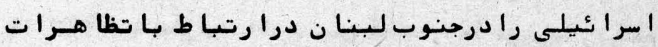

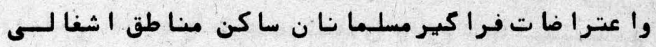

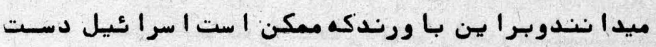

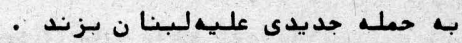

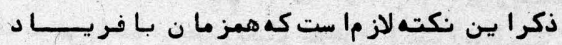

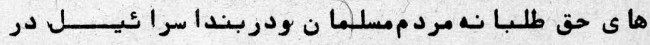

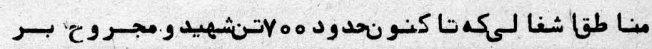

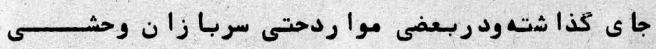

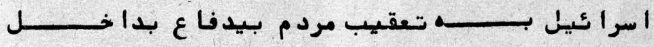

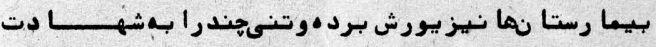

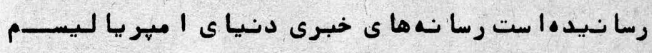

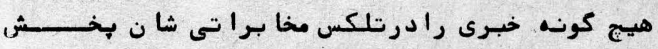

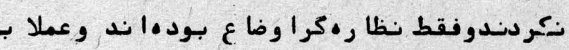

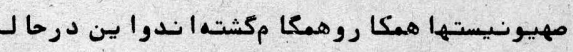

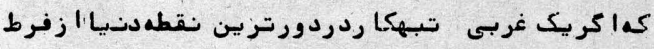

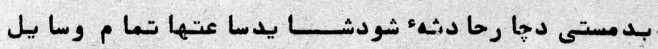

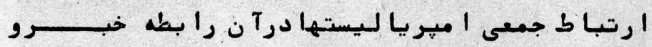

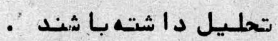

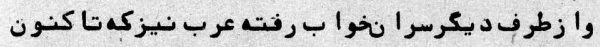

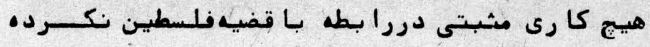

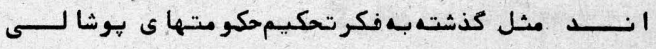

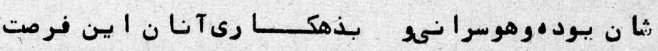

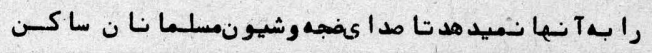




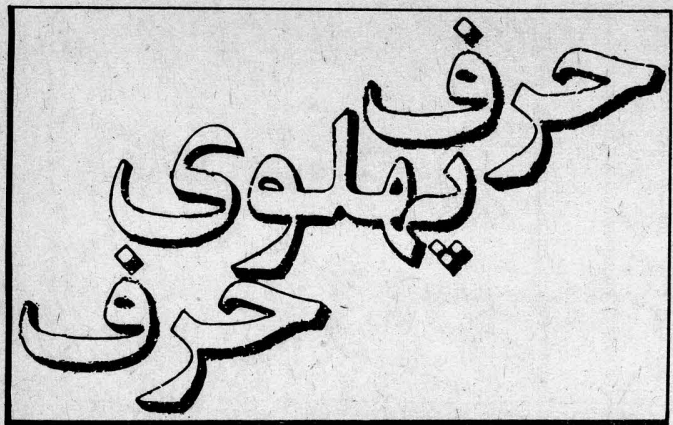

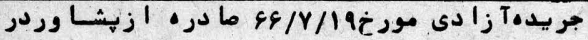

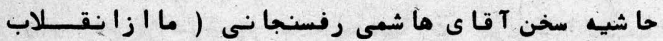

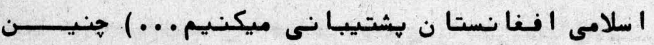

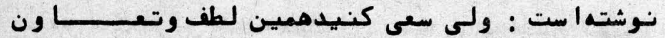

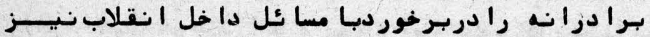

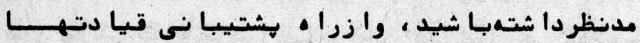

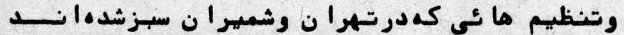

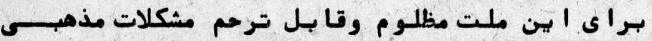

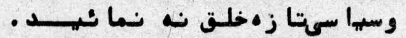

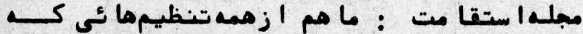

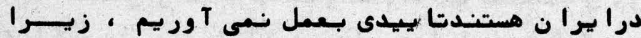

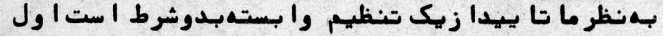

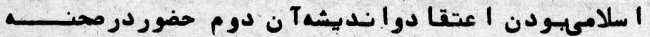

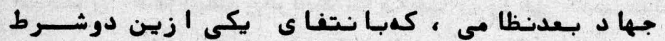

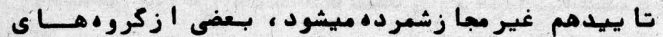

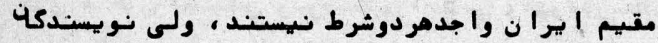

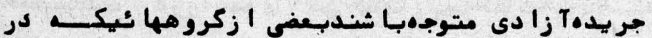

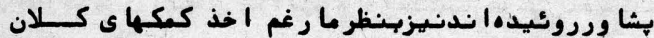
نا تدها صيت انستد

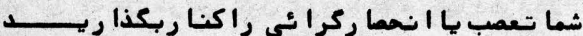
وبين هشا وروتهرا' ن فرقى نكذا ريد ، جشم خودرا باز

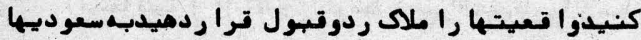

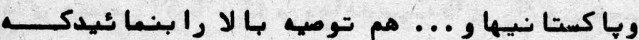

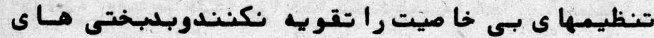

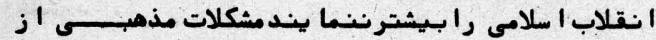

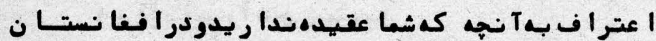

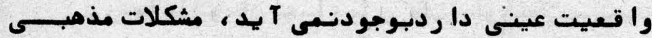

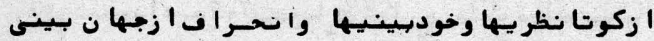

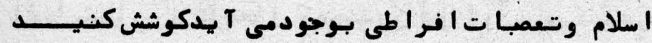

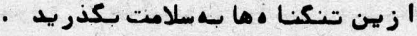

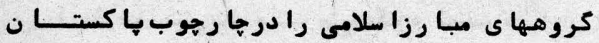

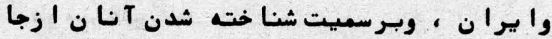

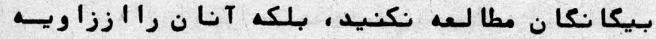

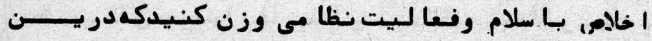

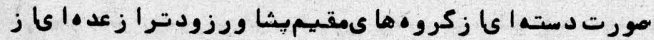

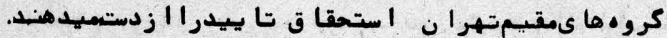

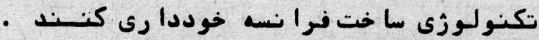

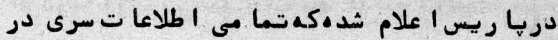

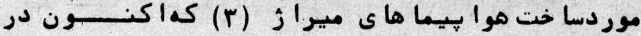

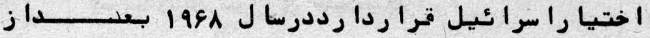

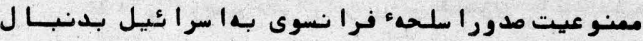

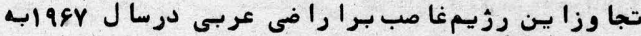

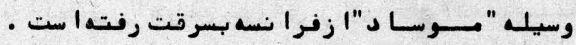

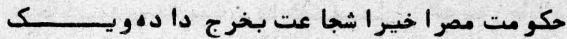

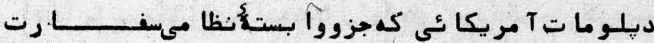

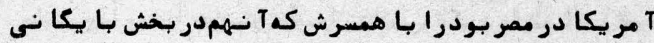

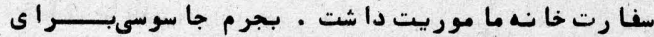

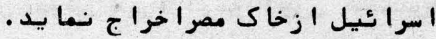

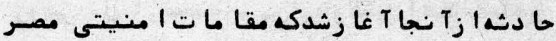

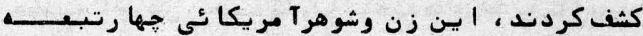

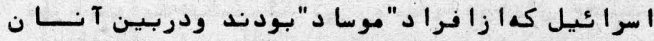

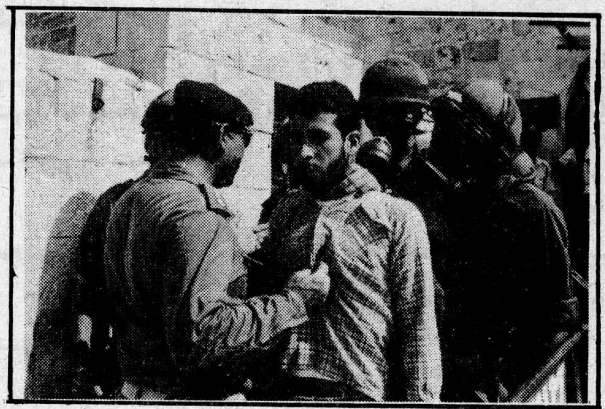

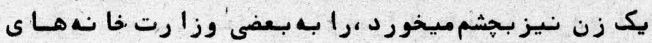

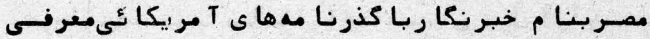

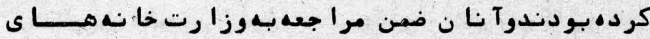

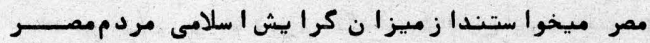

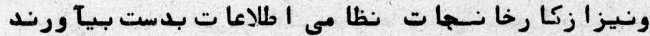

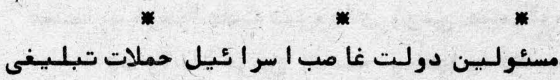

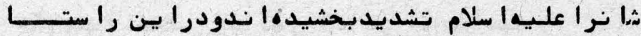

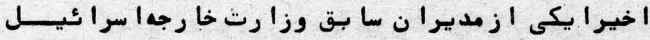

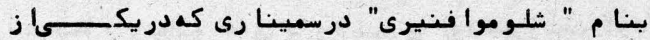

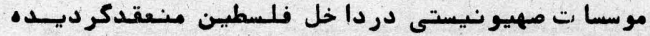

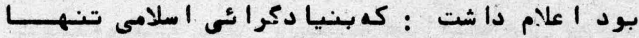

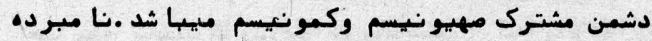

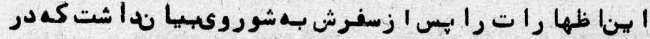

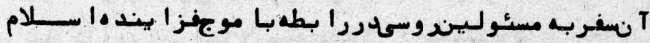

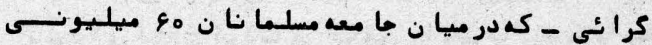

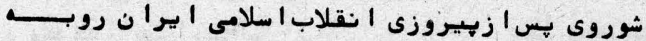

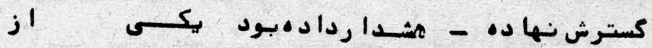

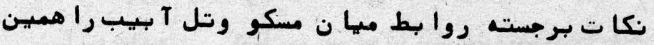

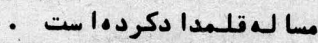




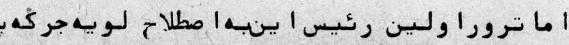

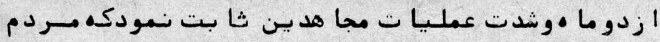

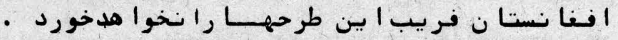

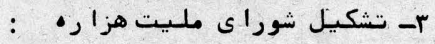

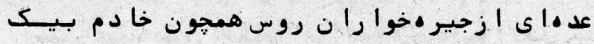

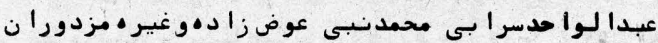

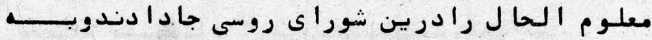

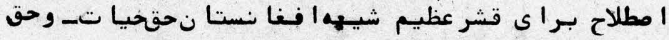

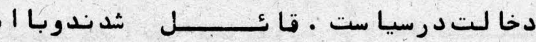

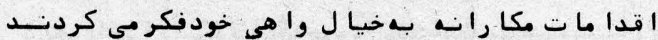

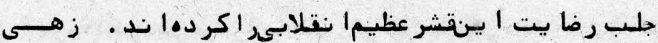

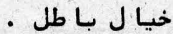

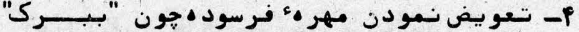

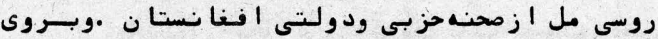

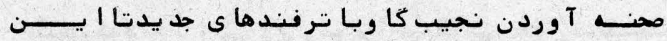

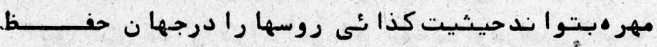

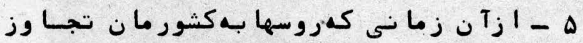

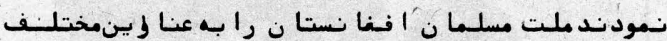
يا دمى كردند.

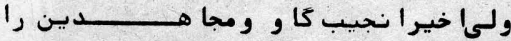

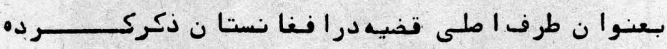

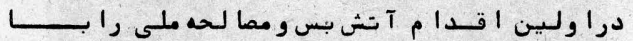

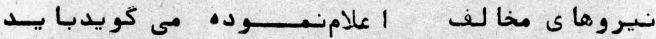

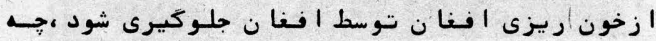

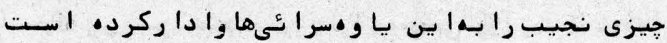

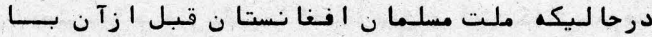

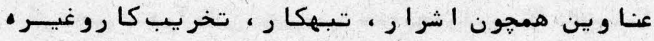

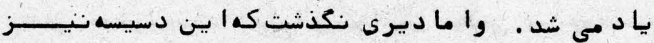

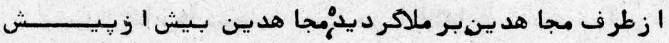

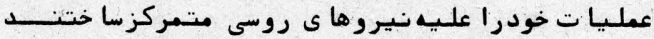

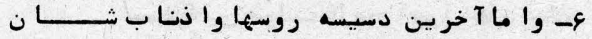

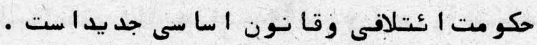

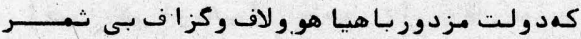

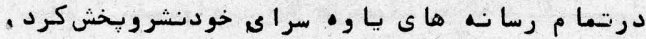

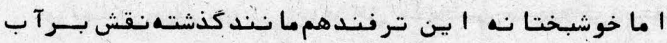

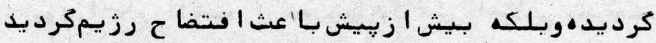

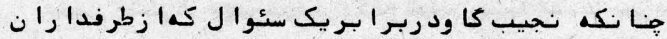

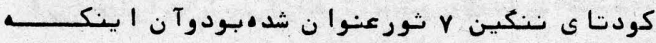

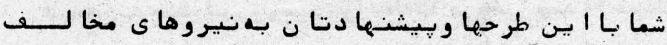

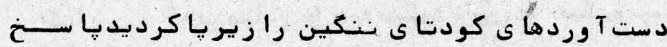

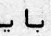

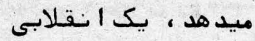

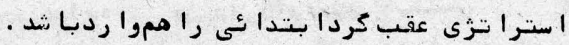

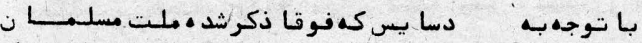

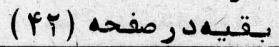

\section{انقلاب|سلامىو}

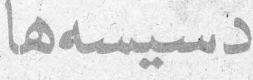

|

بروا فع است كمدروس ها ا زآن روزى كمقدم نحس

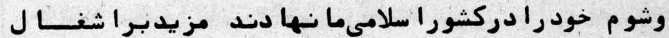

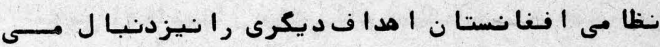

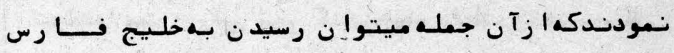

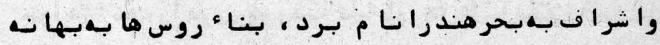

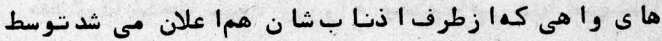

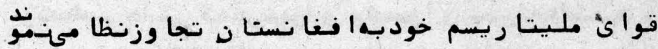

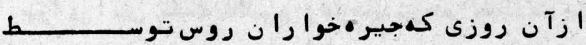

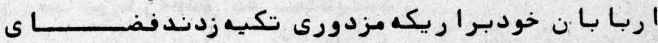

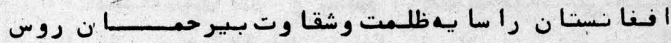

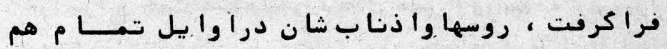

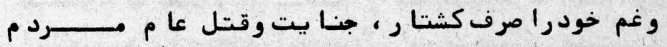

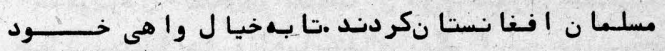

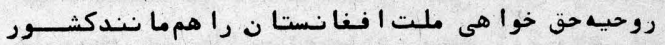

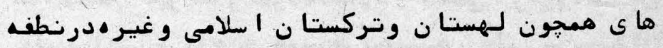

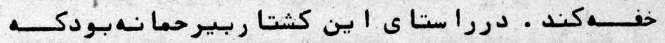

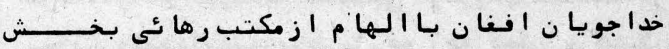

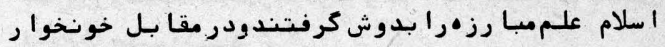

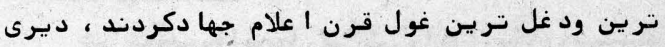

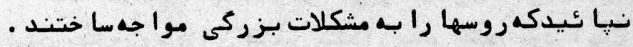

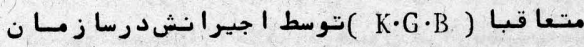

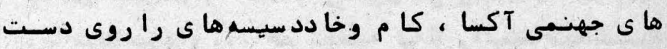

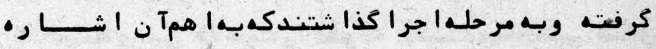

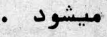

$$
\text { ا }
$$

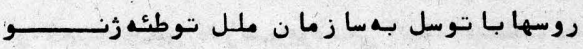

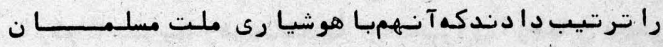

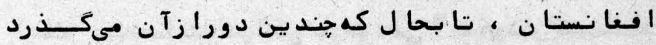

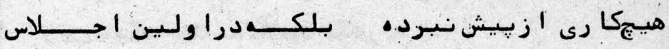

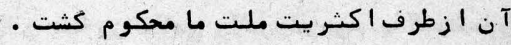

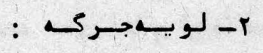

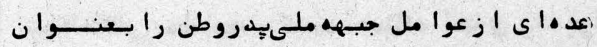

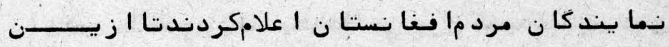

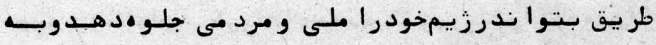

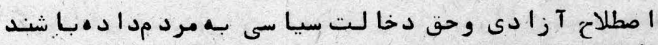




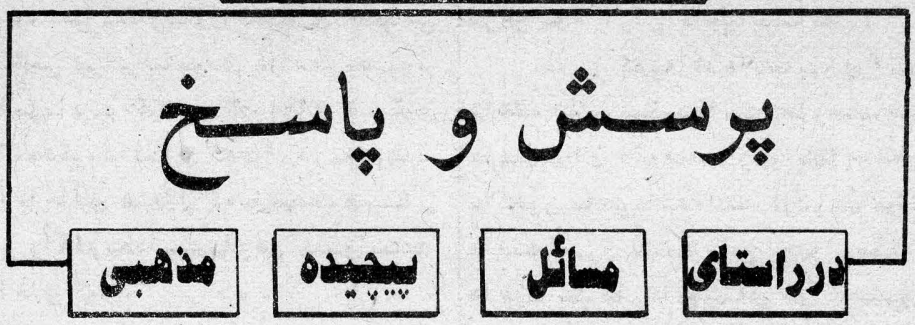

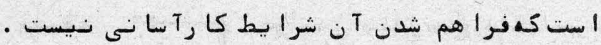

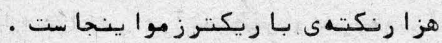

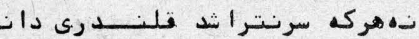

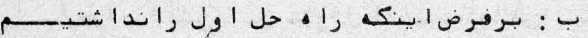

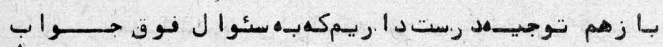

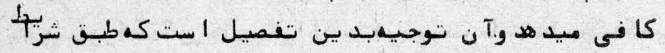

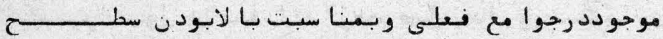

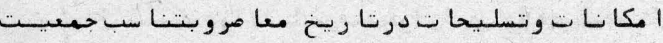

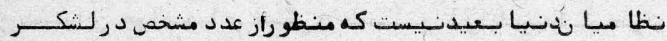

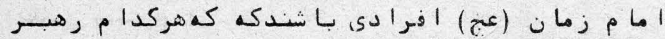

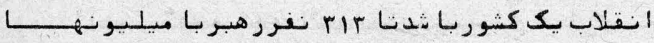

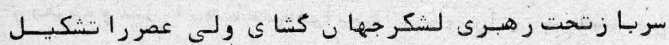

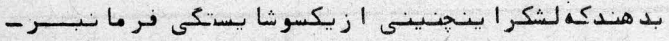

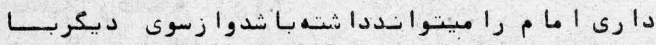

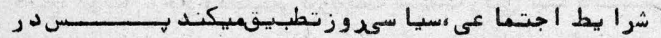

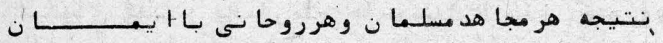

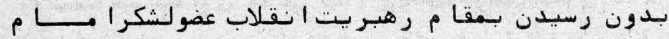

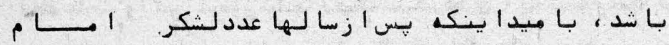

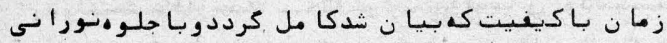

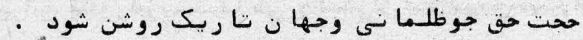

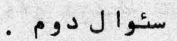

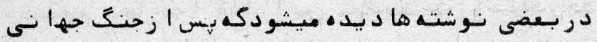

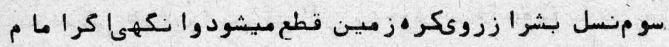

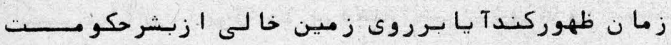

$$
\text { ميكنــ }
$$

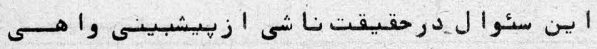

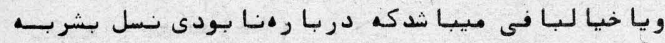

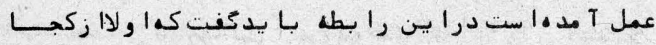

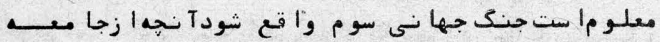

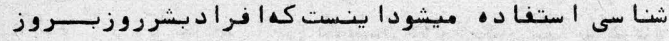

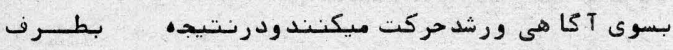

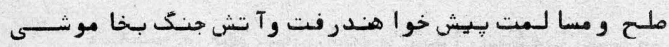

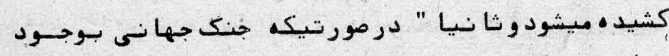

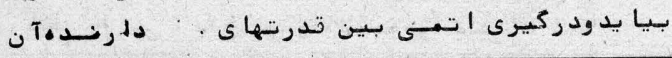

$$
\begin{aligned}
& \text { برادر جعفرما دقى ازيثا ور : }
\end{aligned}
$$

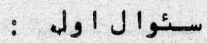

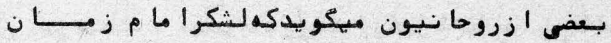

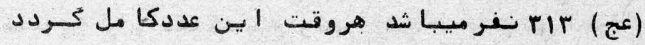

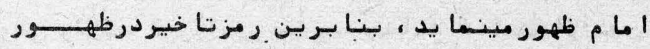

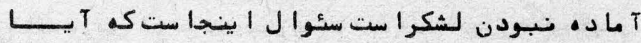

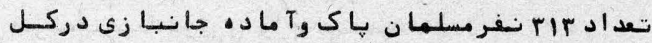

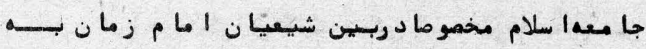

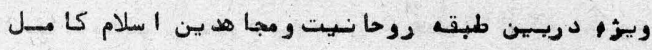

$$
\begin{aligned}
& \text { نسميطود ؟ }
\end{aligned}
$$

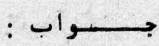

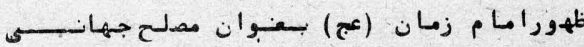

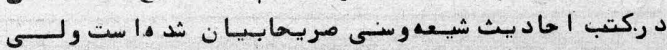

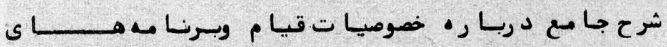

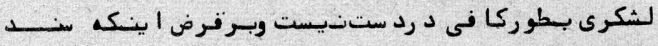

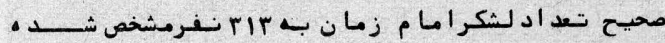

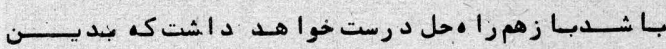

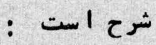

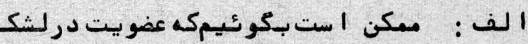

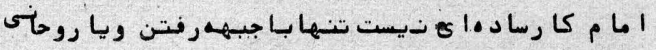

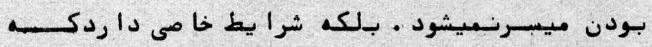

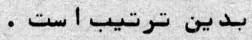

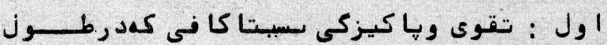

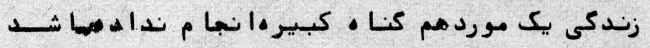

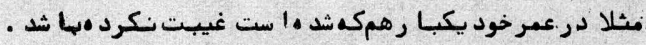

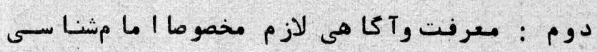

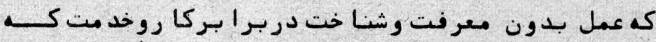

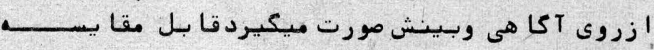

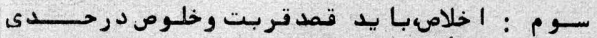

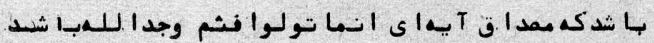

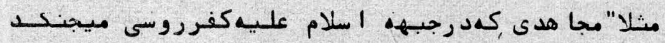

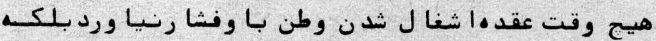

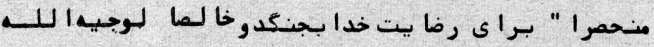

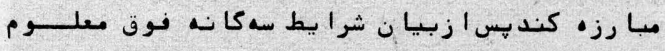




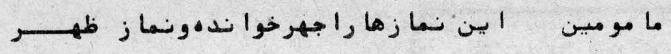

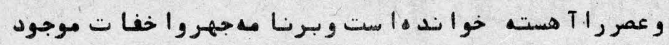

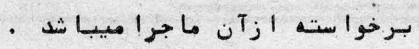

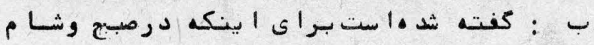

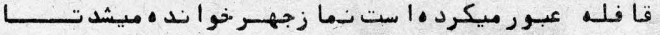

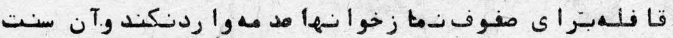

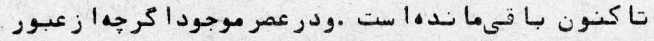

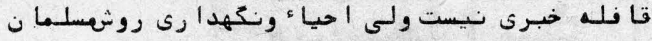

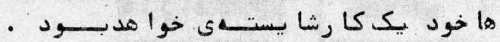

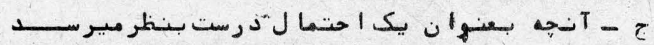

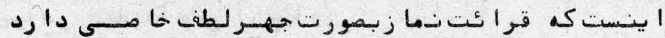

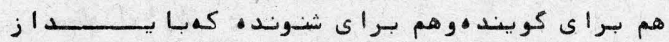

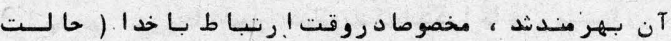

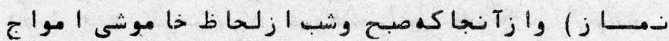

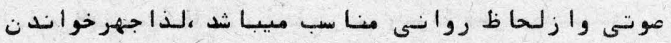

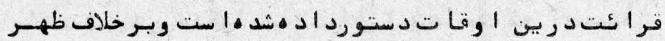

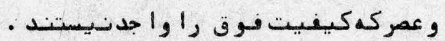

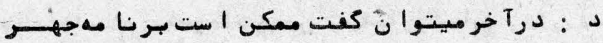

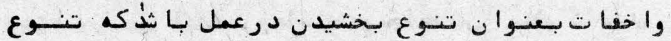

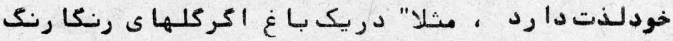

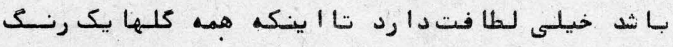

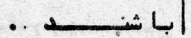

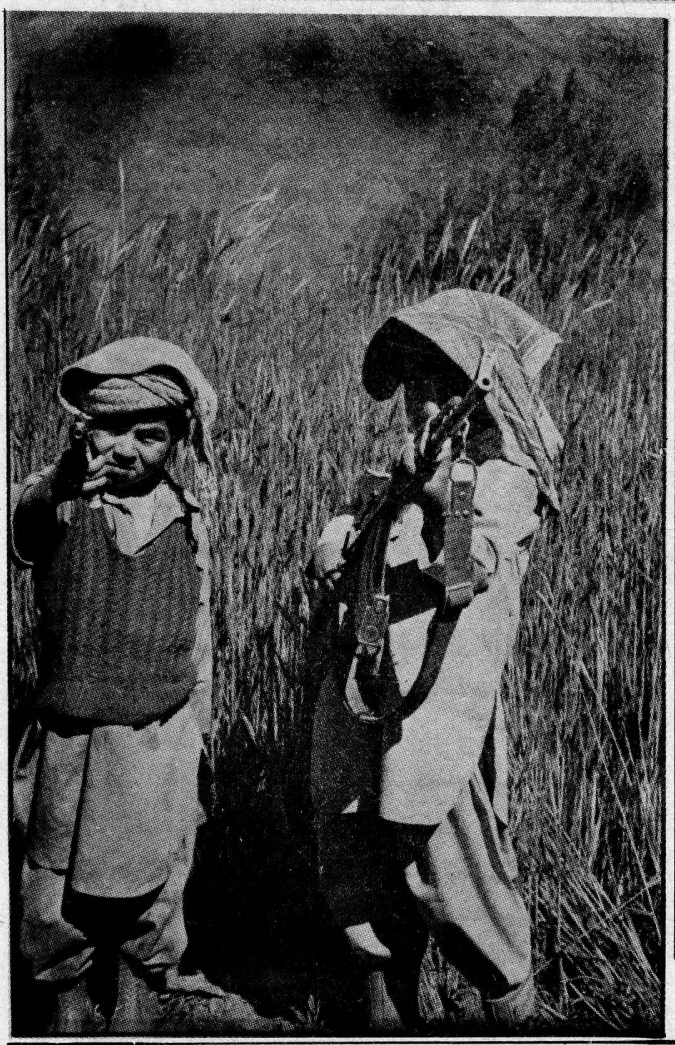

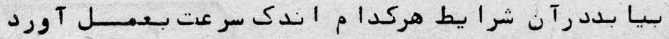

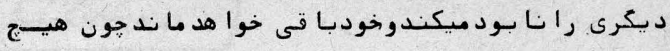

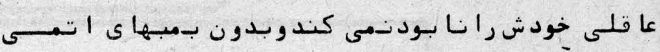

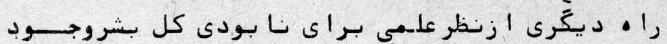

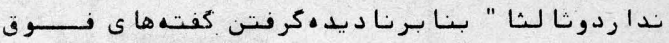

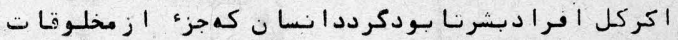

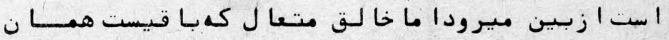

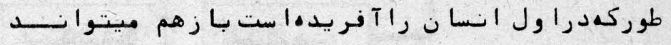

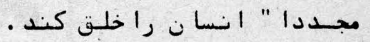

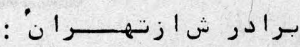

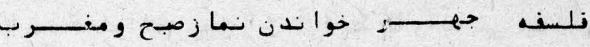

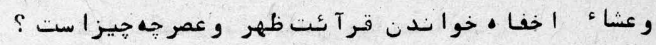

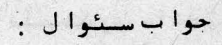

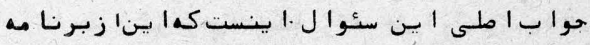

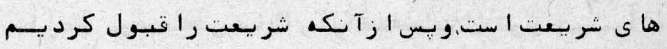

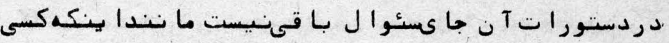

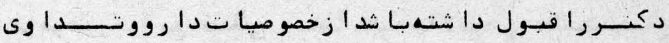

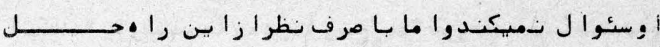

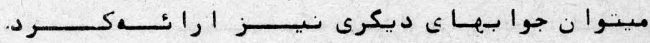
: بدن شن ش

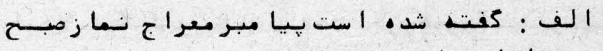

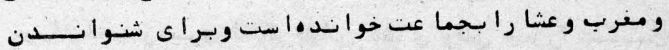

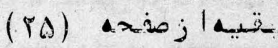

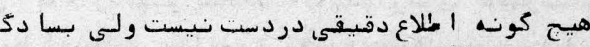

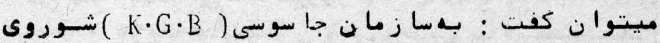

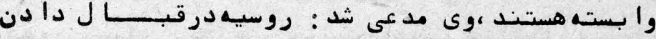

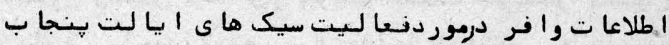

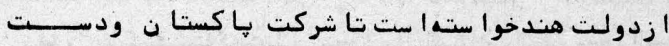
دا شتن آن كشورد ر بـتسيبا نى وكسترش فعا لـيت سيك ها

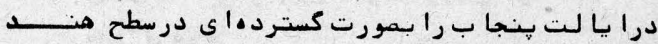

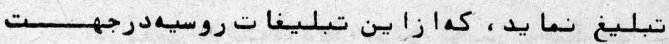

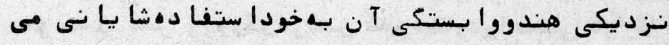

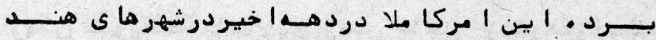

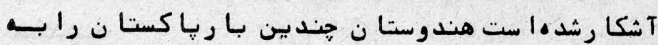

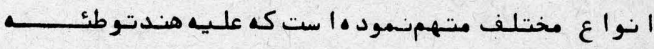

(ro)

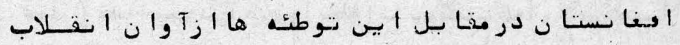

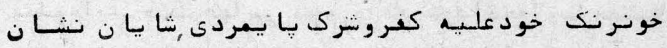

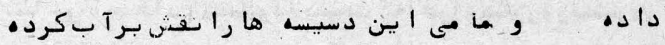

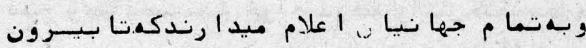

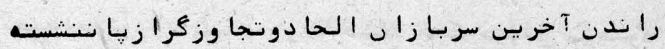

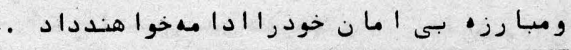




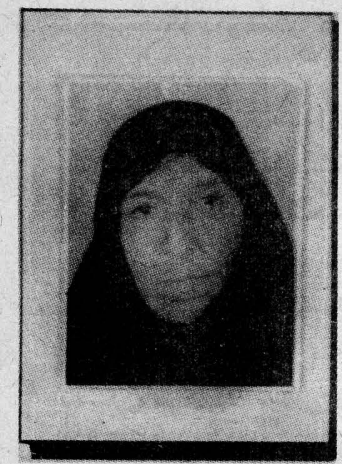

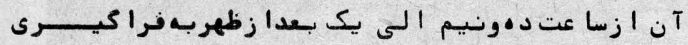

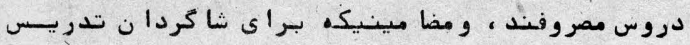

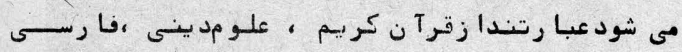

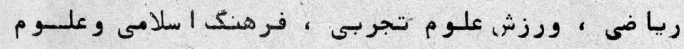

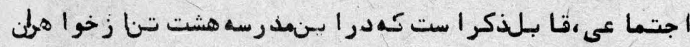

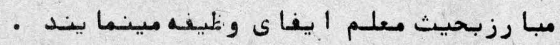

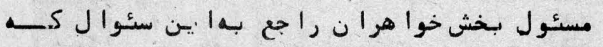

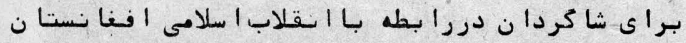

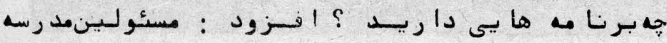

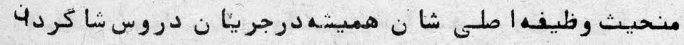

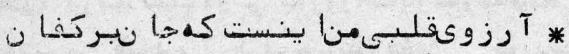

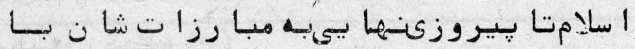

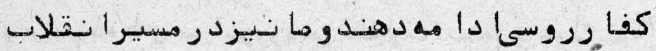

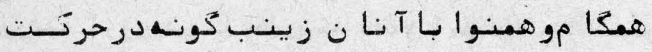

$$
\text { نوا هيمبرد }
$$

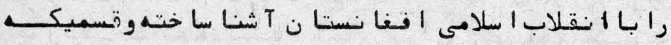

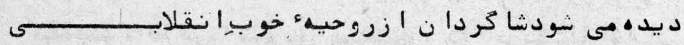

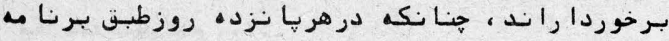

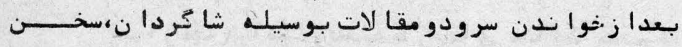

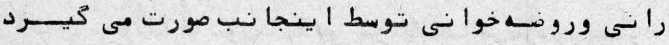

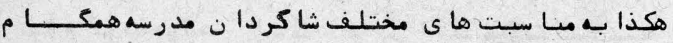

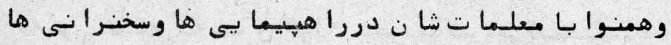

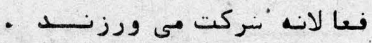

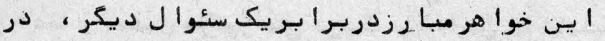

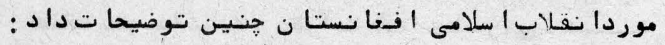

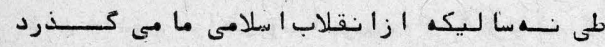

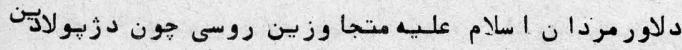

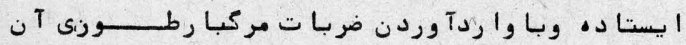

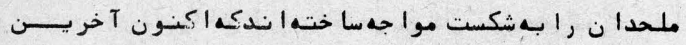

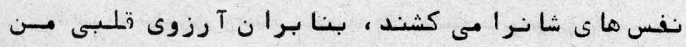

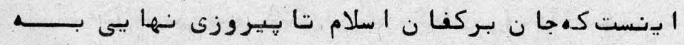

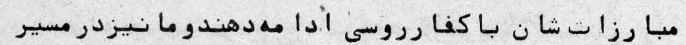

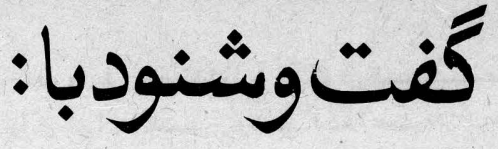

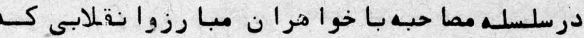

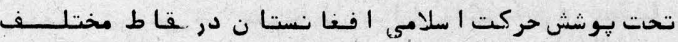

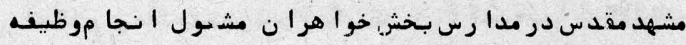

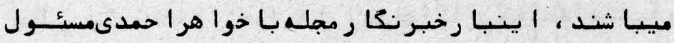

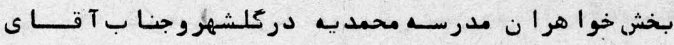

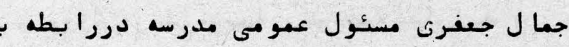

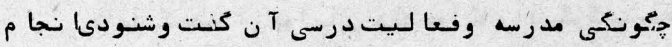

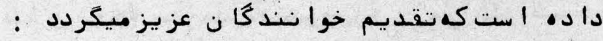

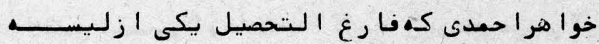

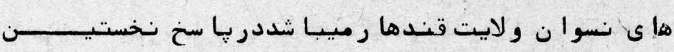

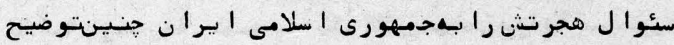
داد

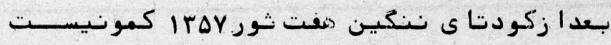

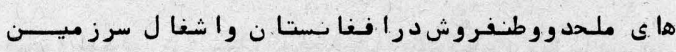

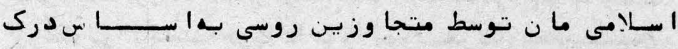

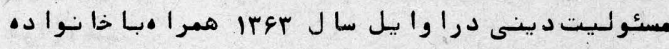

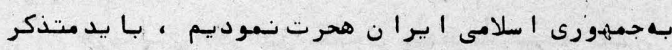

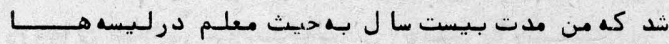

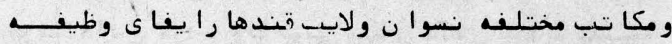
مينمودم

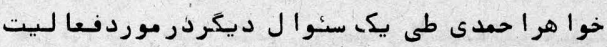

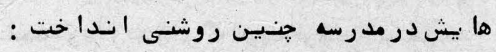

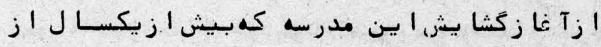

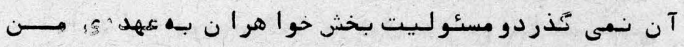

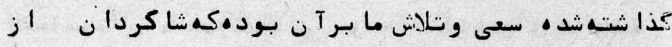

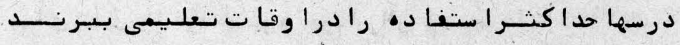

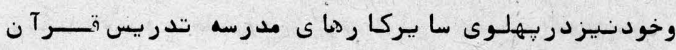

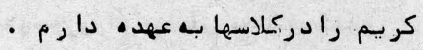

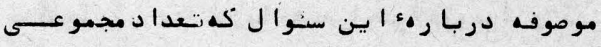

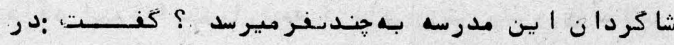

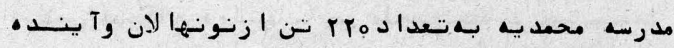

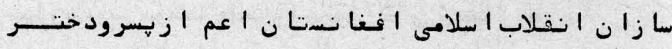

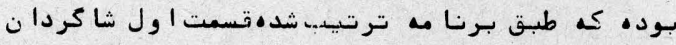

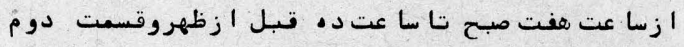




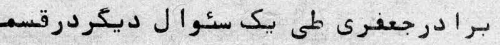

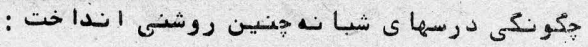

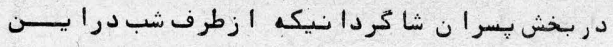

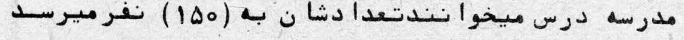

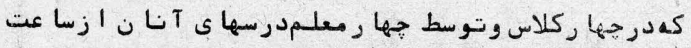

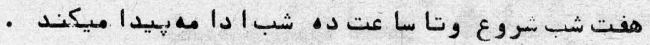

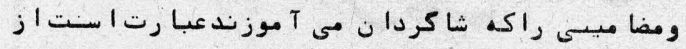

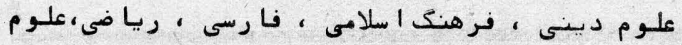

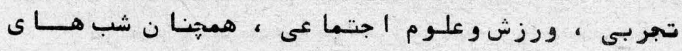

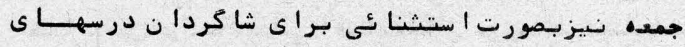

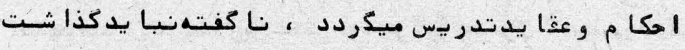

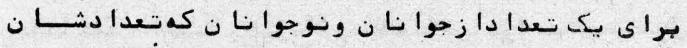

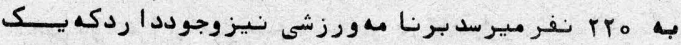

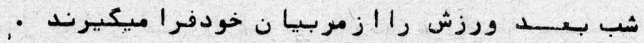

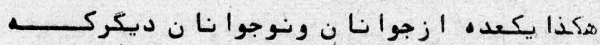

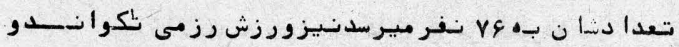

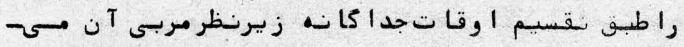

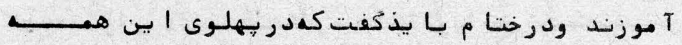

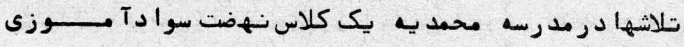

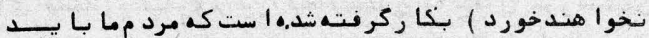

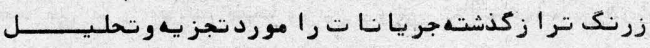

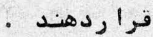

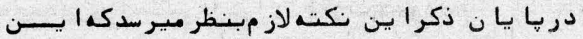

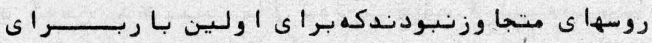

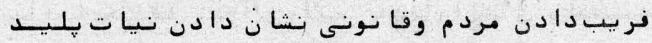

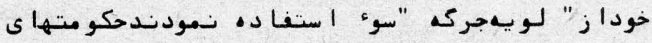

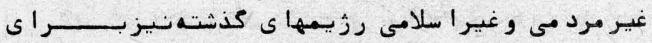

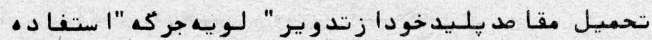

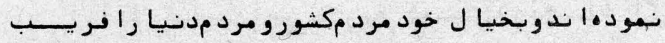

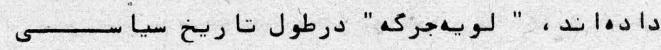

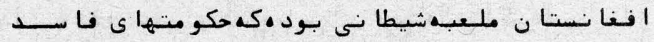

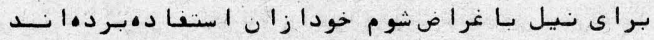

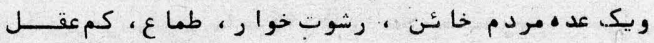

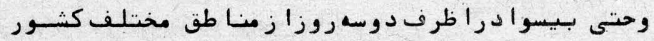

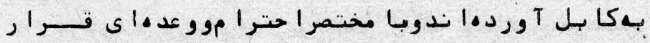

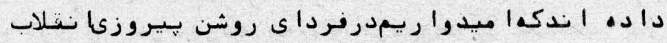

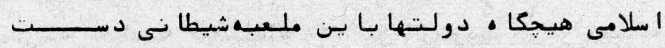

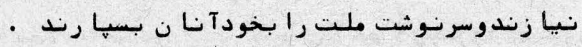

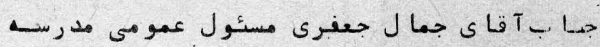

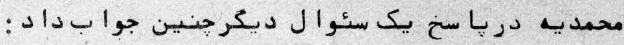

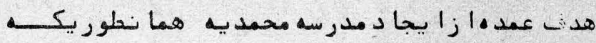

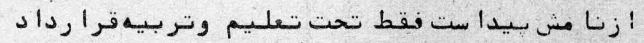

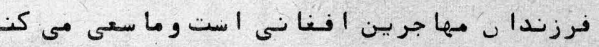

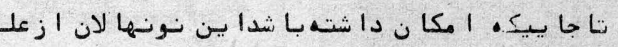

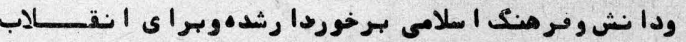

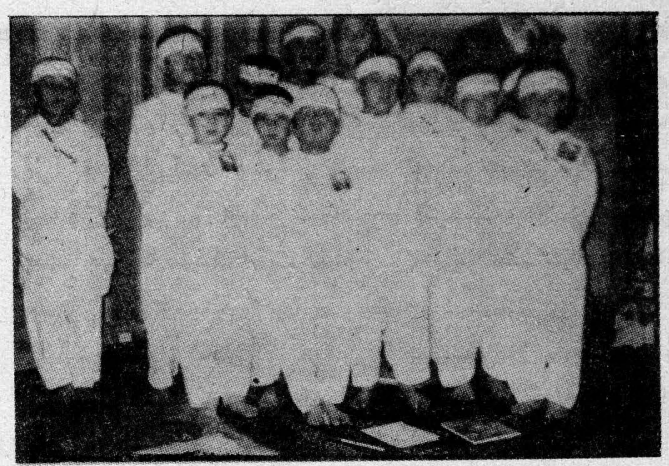

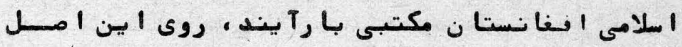

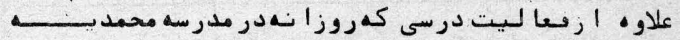

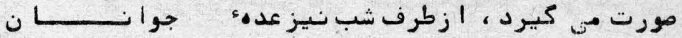

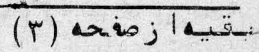

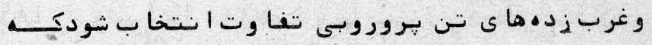

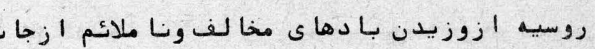

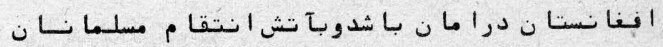

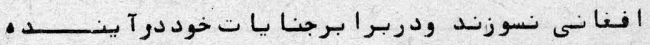

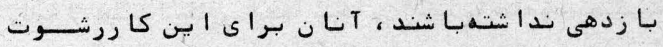

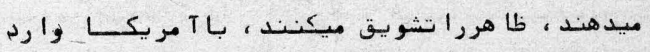

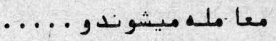

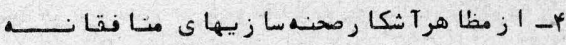

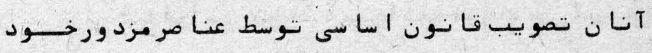

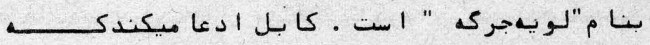

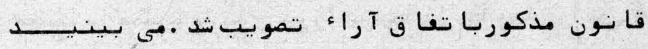

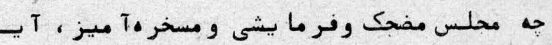

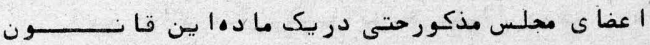

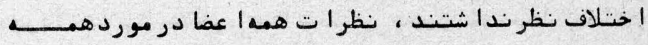

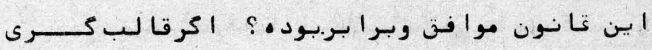

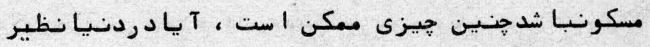
- $د$ is

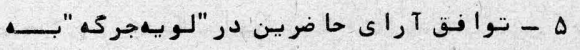

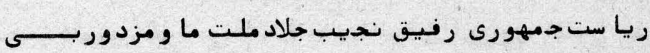

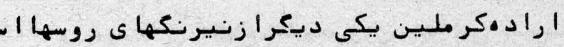

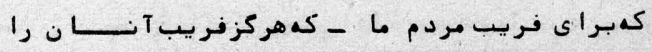




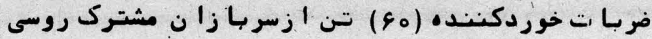

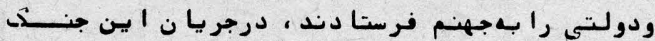

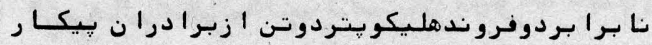

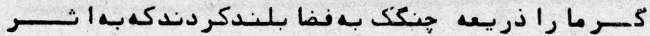

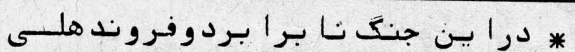

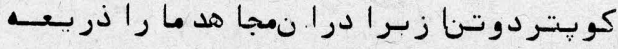

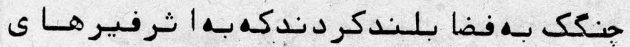

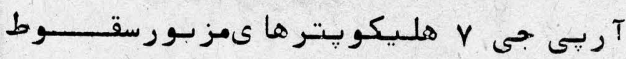

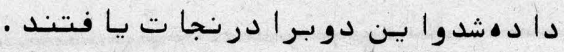

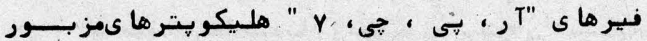

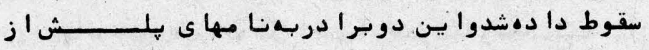

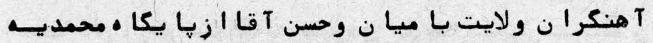

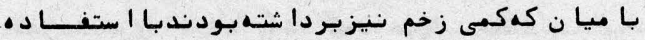

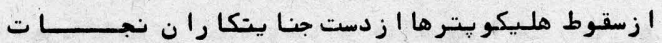

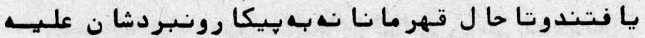

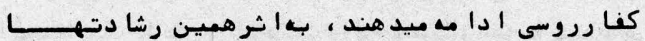

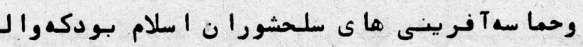

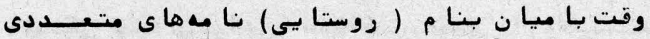

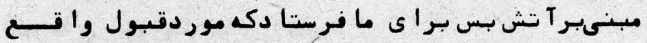

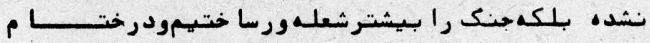

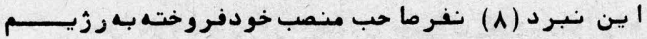

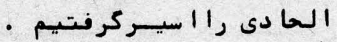

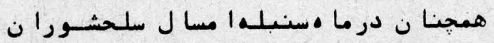

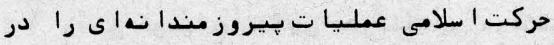

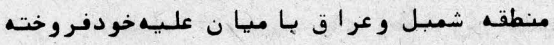

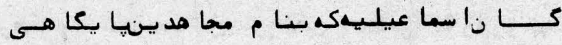

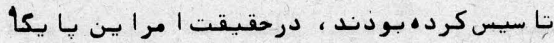

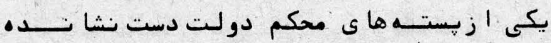

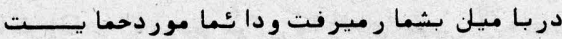

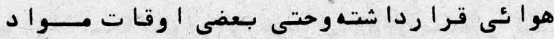

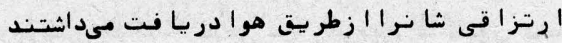

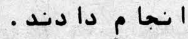

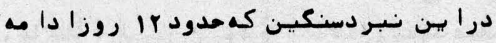

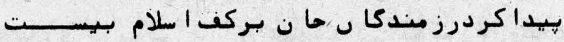

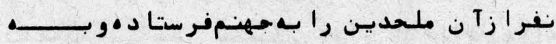

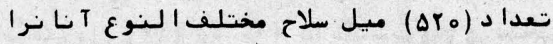

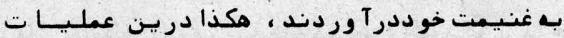

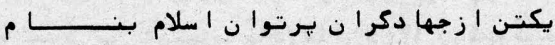

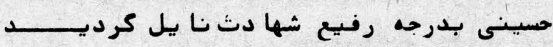

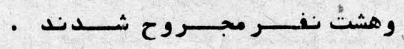

آقاى محمدى را جع با ين سئوال له حركي

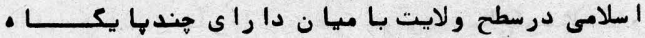

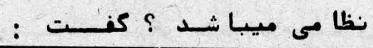

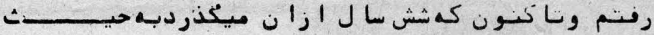

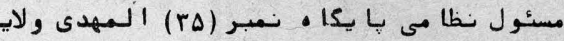

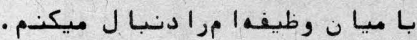

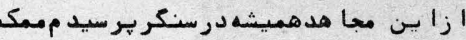

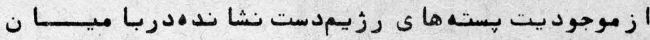

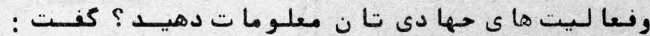

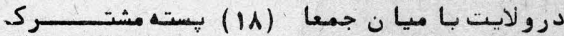

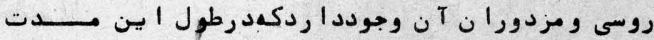

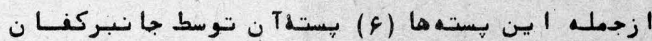

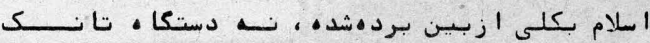

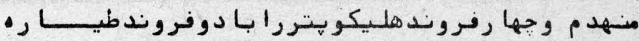

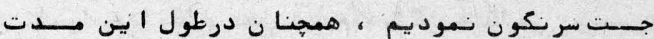

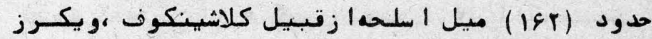

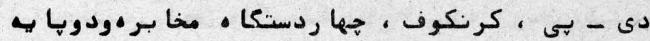

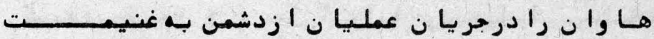

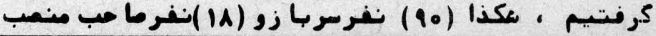

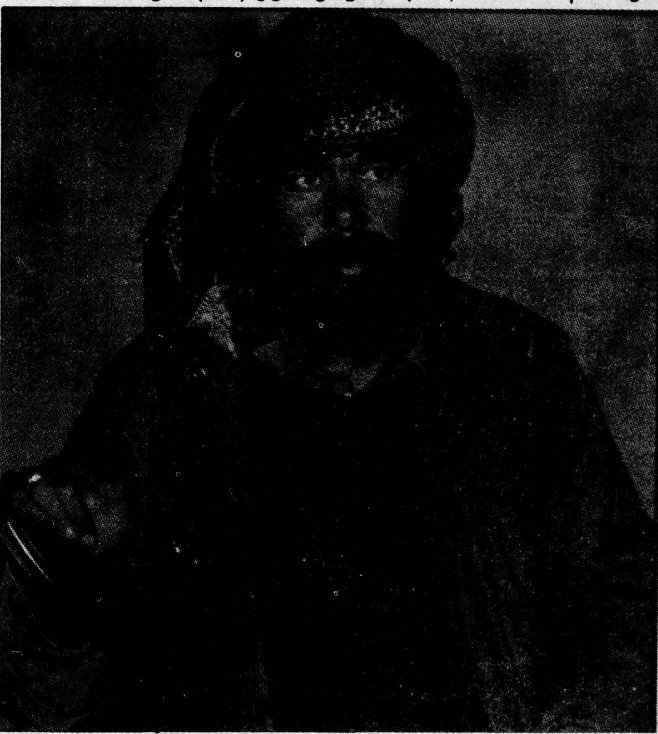

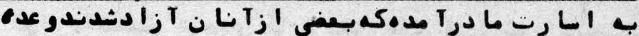

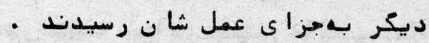

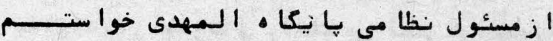

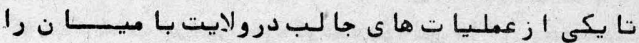

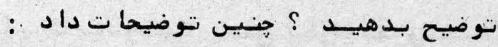

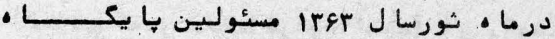

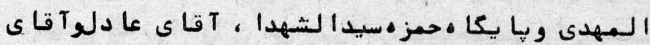

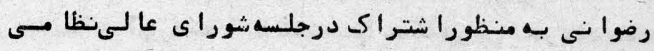

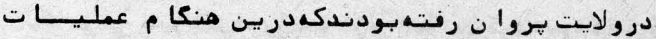

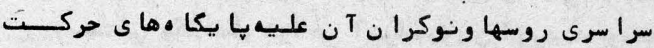

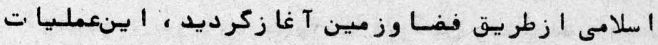

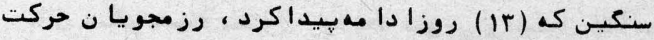

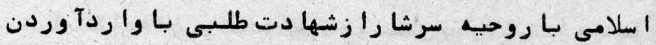


بسم اللـها لرحمسن الرحيـم

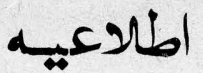

ومكروو مكرا للـهوا اللـهيرا لـما كـــر يـن

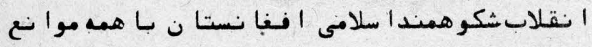

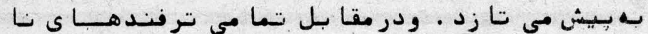

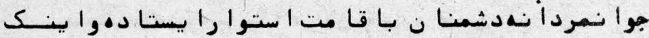

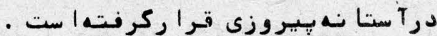

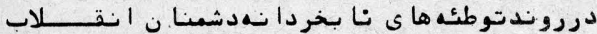

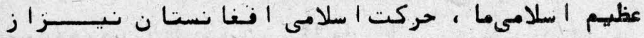

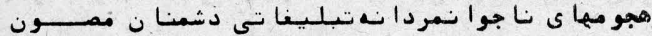

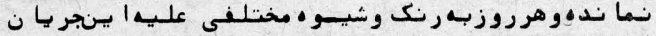

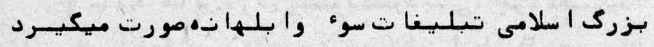

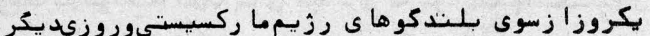

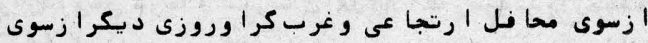

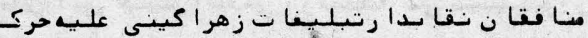

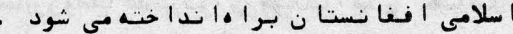

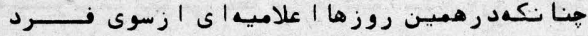

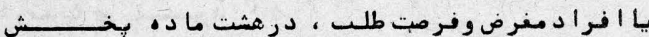

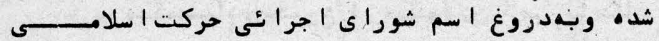

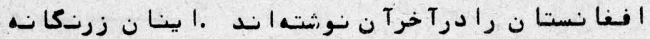

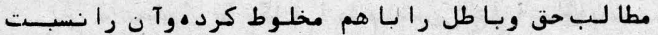

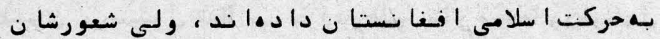

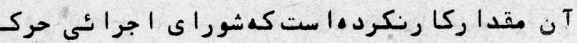

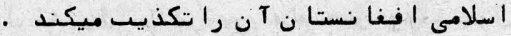

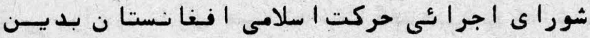

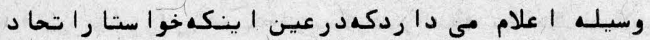

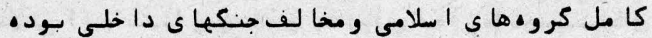

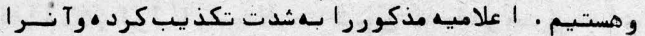

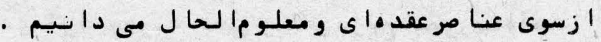

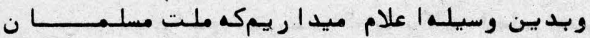

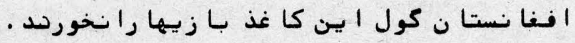

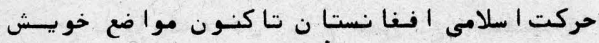

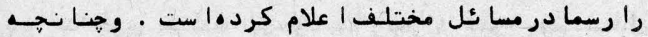

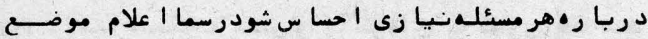

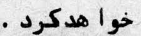

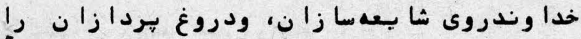

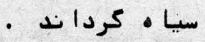

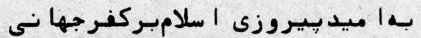

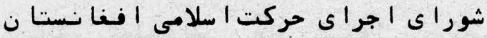

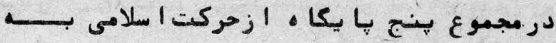

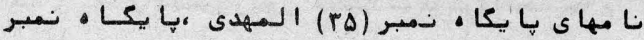

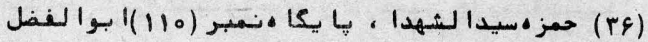

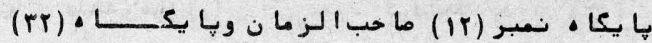

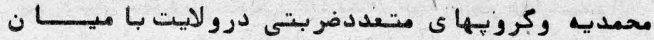

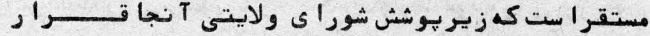

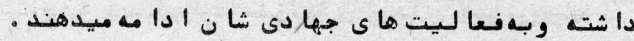

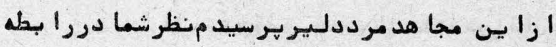

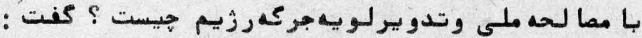

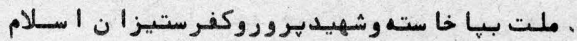

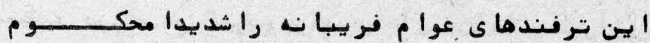

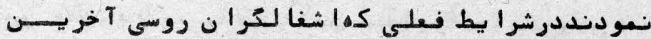

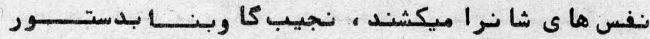

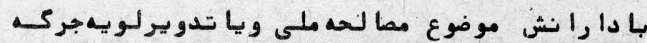

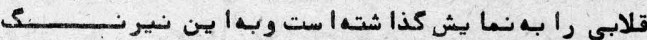

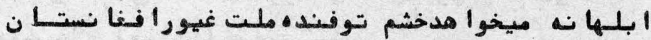

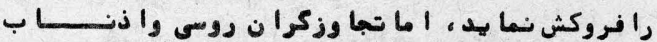

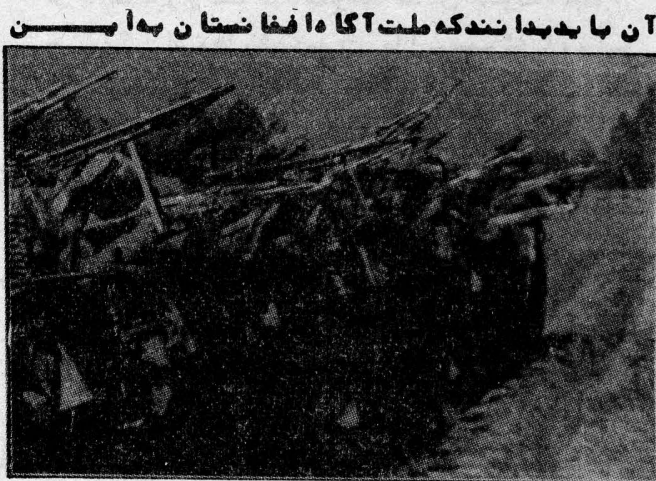

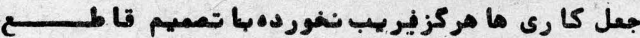

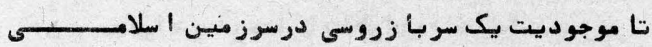

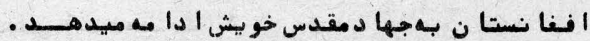

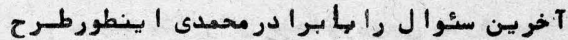

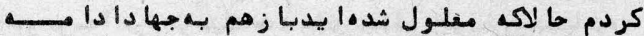

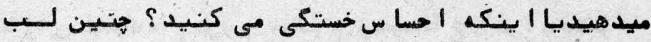

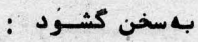

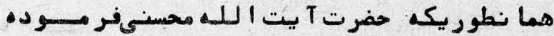

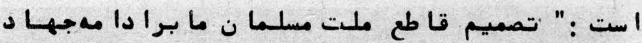

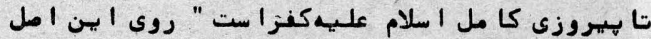

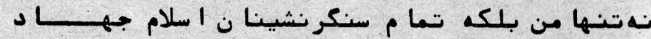

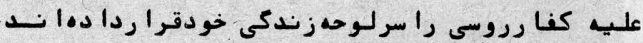

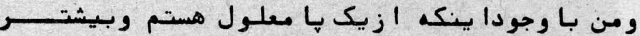

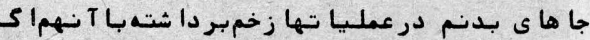

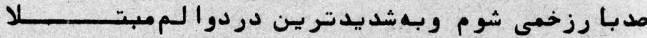

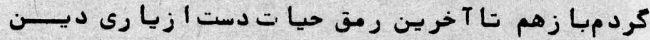

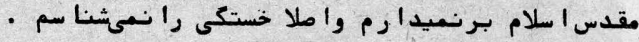




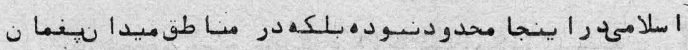

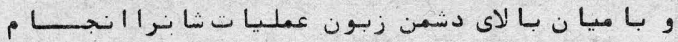

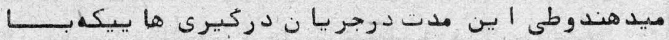

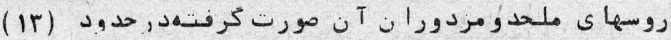

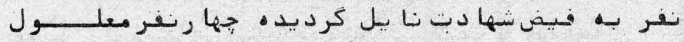

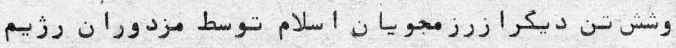

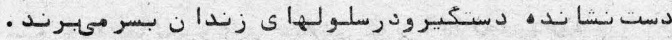

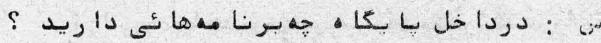

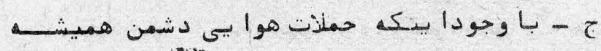

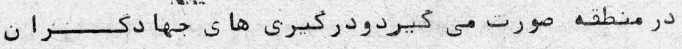

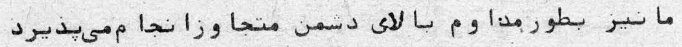

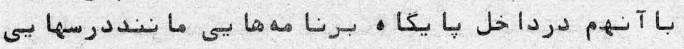

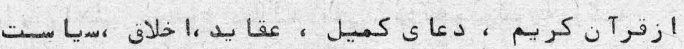

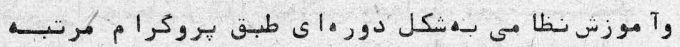

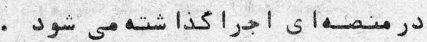

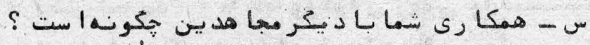

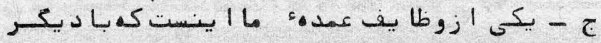

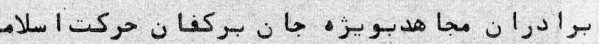

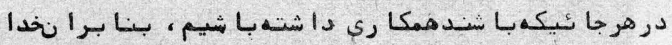

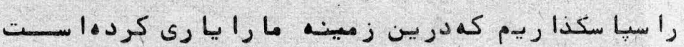

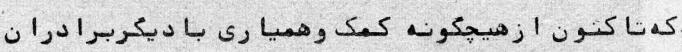

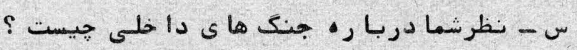

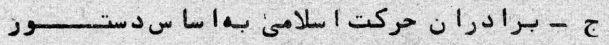

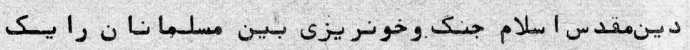

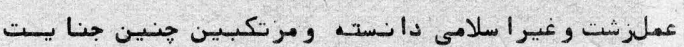

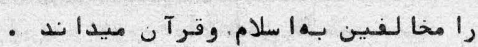

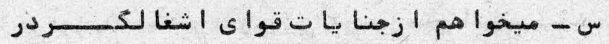

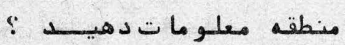

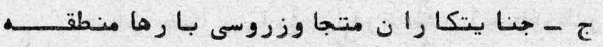

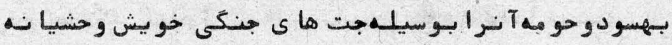

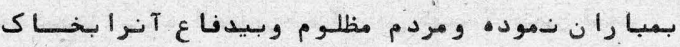

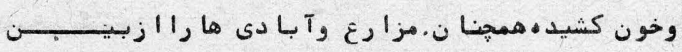

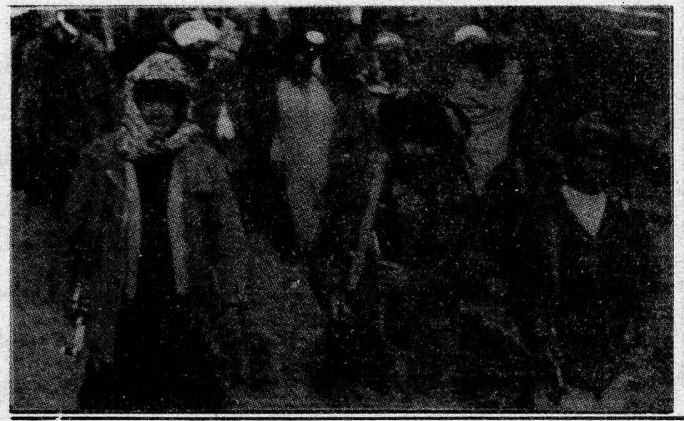

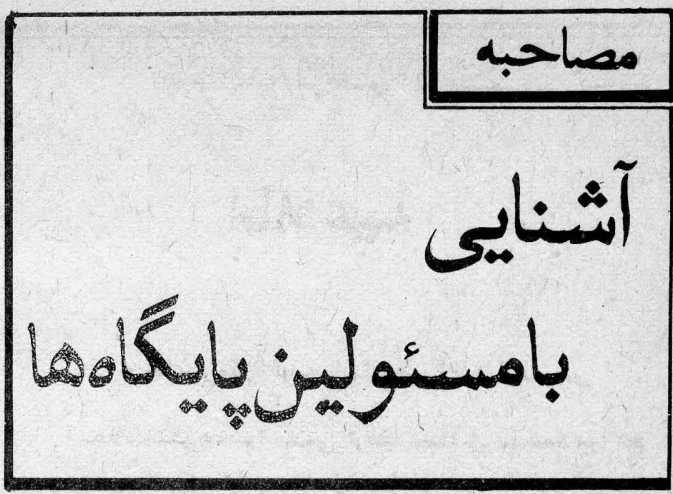

مدطقهبجسود يا يعا • ه ه ا ما م حسن (ع) )

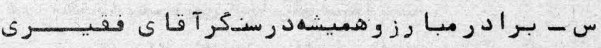

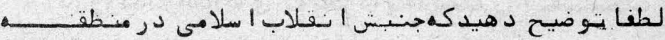

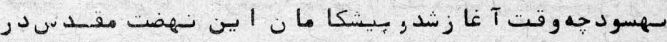

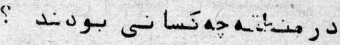

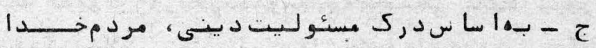

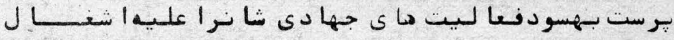

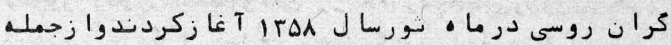

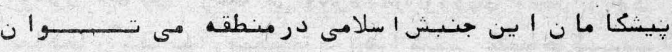

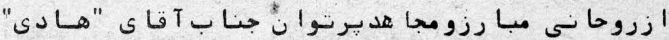

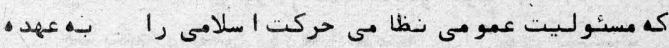

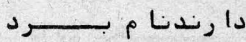

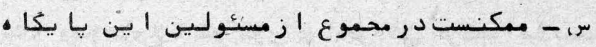

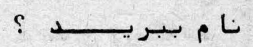

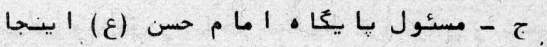

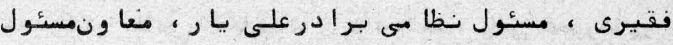

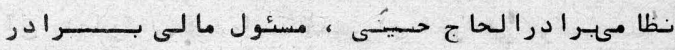

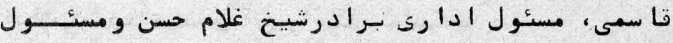

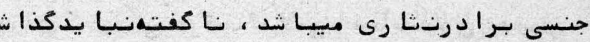

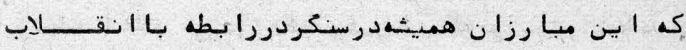

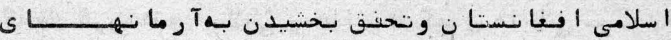

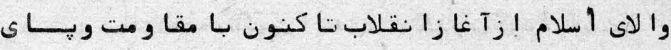

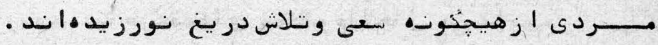

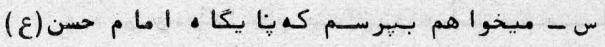

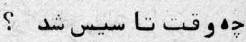

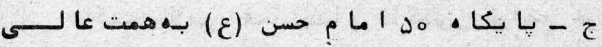

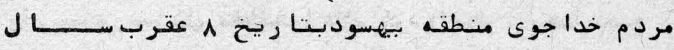

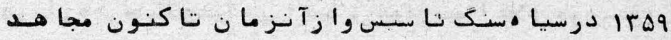

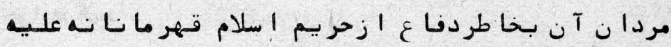

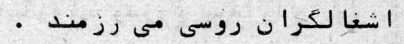

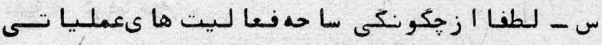

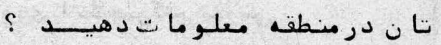

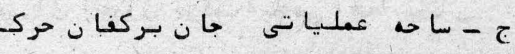




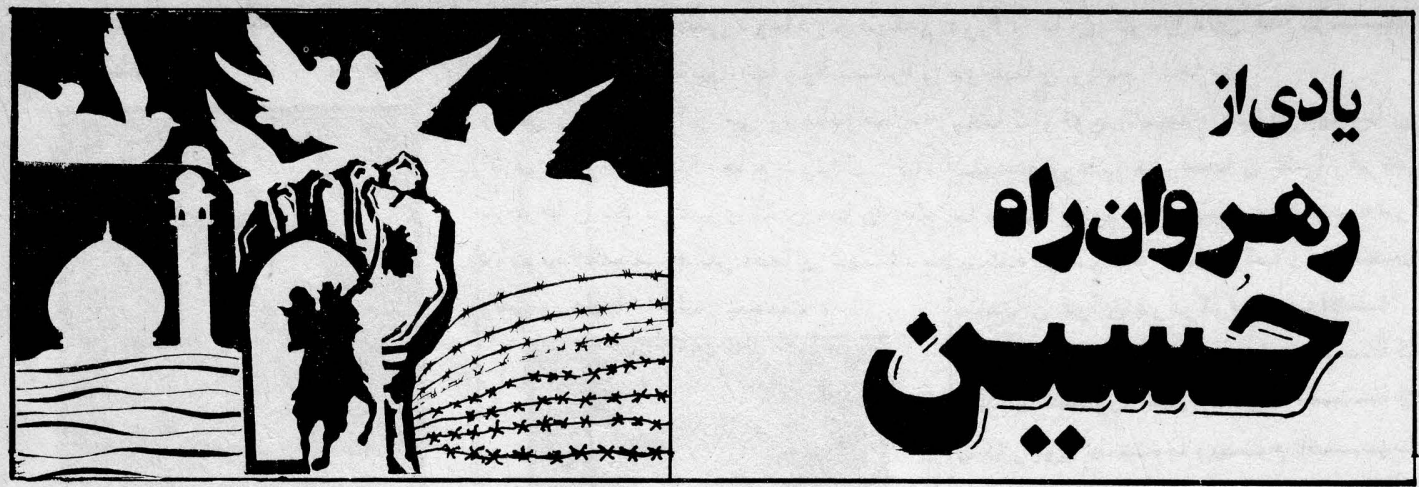

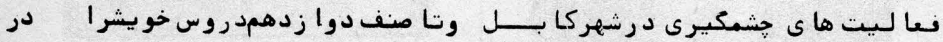

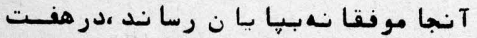

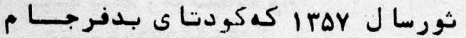

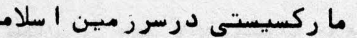

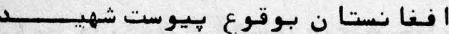

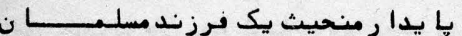

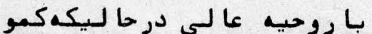

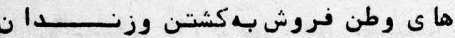

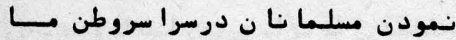

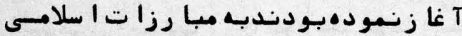

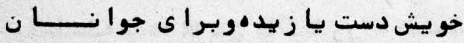

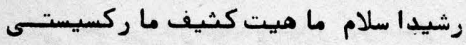

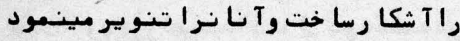

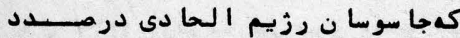

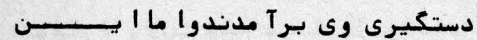

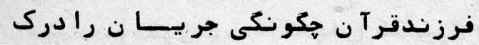

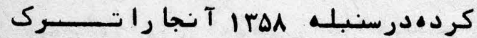

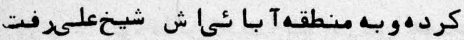
وعليهدشمنا ن دين به جها د مسلحا نـهـ

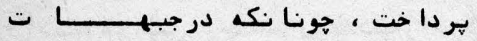

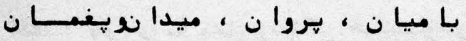

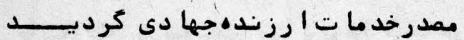

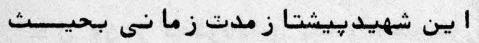

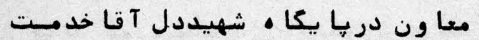

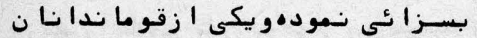

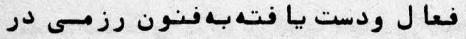

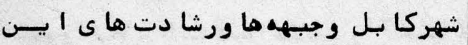

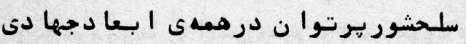

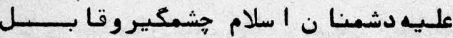

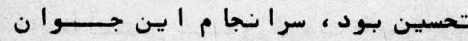

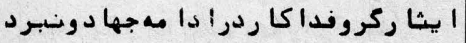

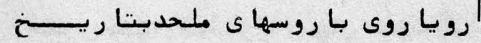

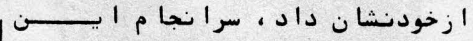

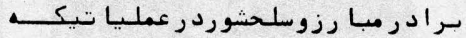

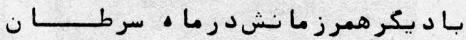

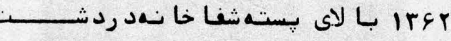

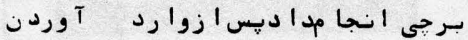

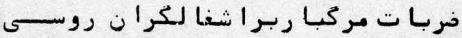

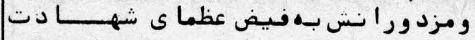

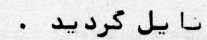

دوش شاد

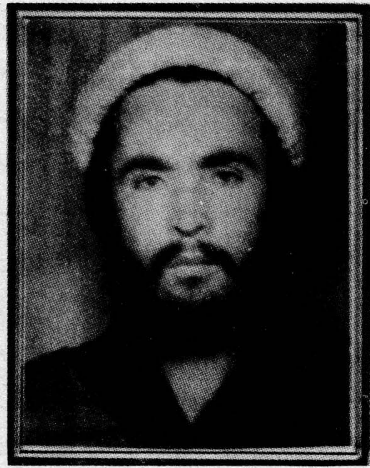

شهيد هيشتا را نجنير محمدنسيـم

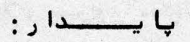

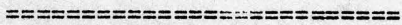

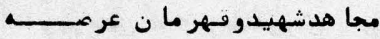

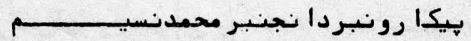

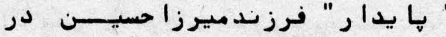

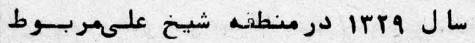

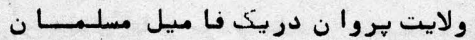

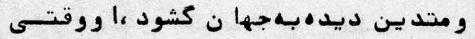

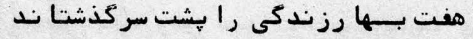

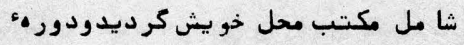

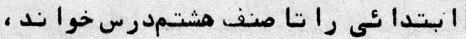

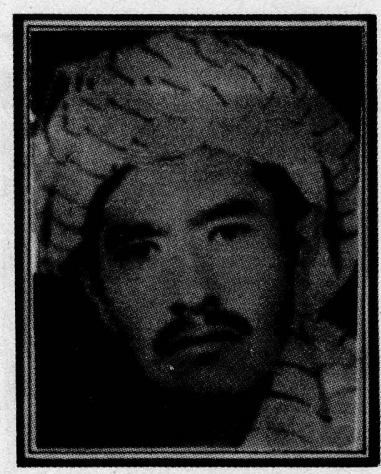

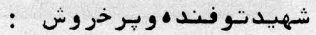
=ニニニニニニニニニニニニニニニニニ

رزمجوى برتوان شهيد "عبدا . .

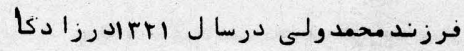

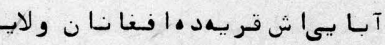

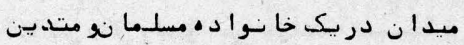

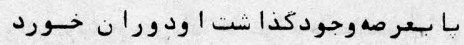

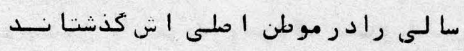

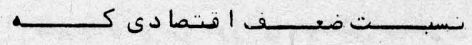

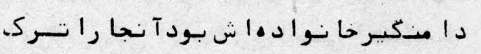

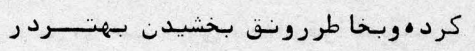

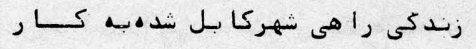

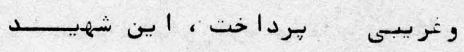

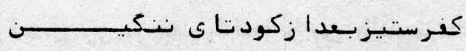

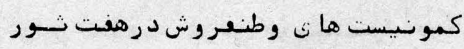

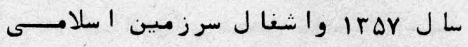

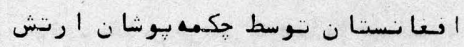

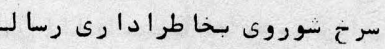

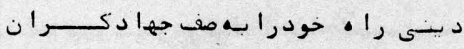

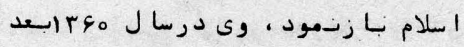

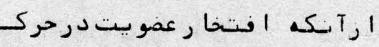

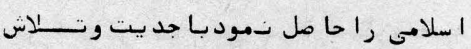

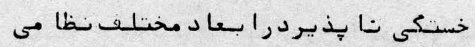




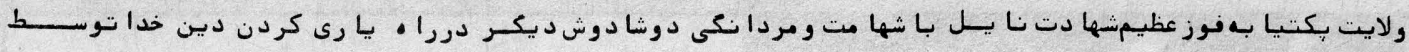

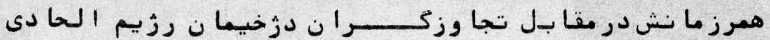

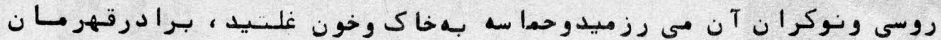

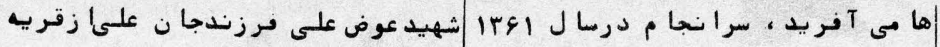

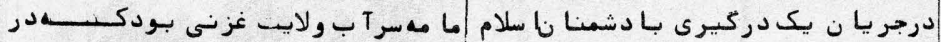

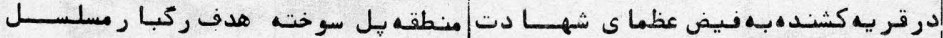

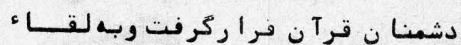

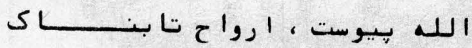

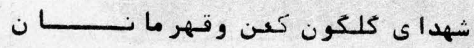

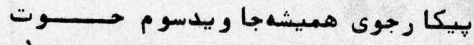

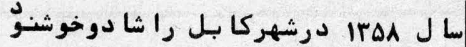

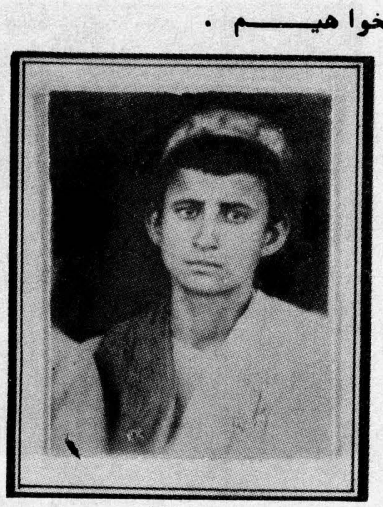

شهيــــنـيـب اللـ

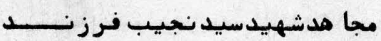

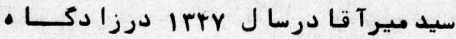

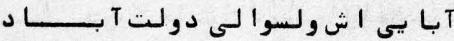

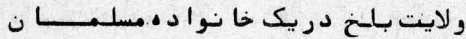

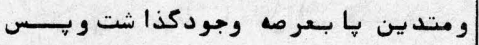

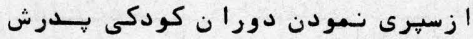

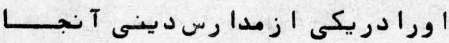

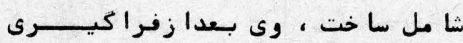

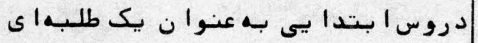

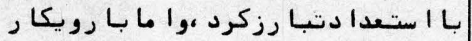

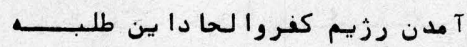

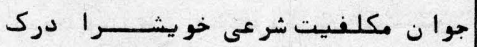

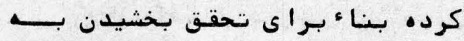

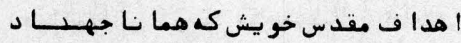

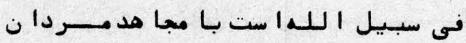

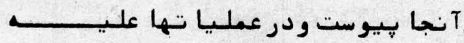

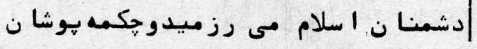

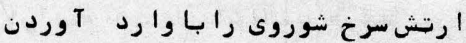

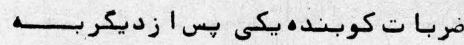

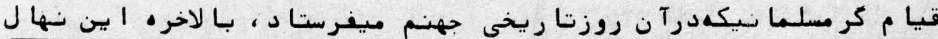

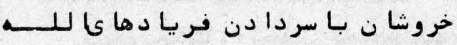

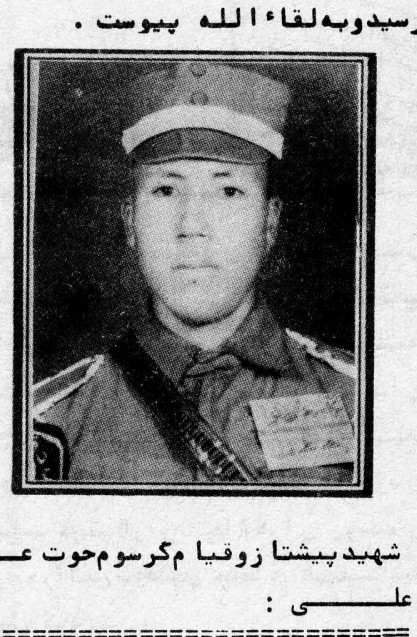

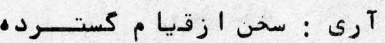

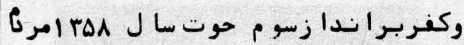

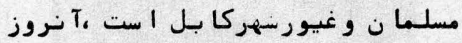

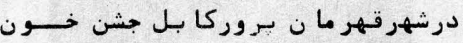

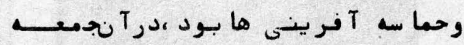

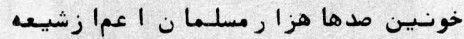

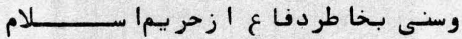

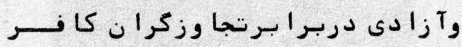

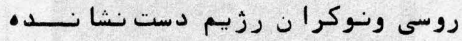

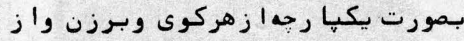

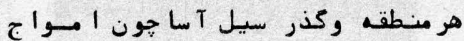

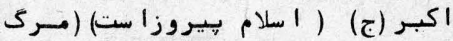

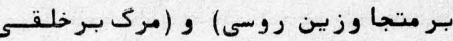

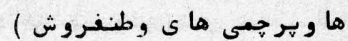

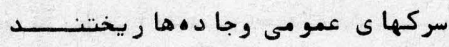

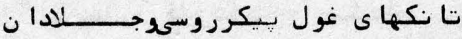

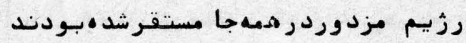

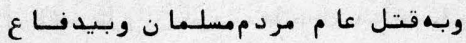

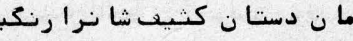

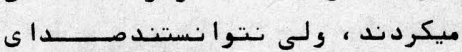

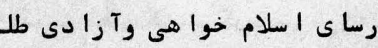
ت

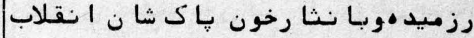

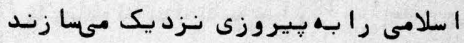

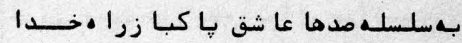

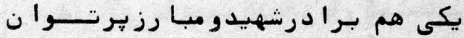

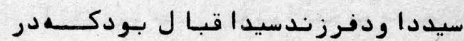

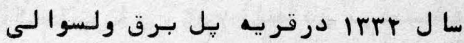

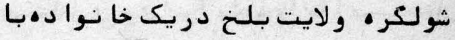

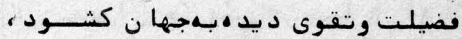

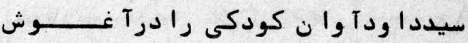

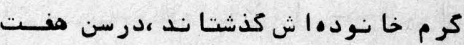

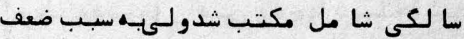

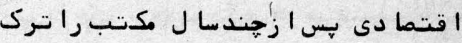

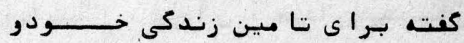

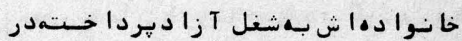
سا ل

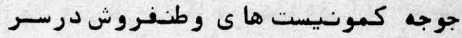

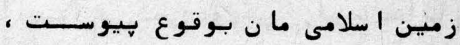

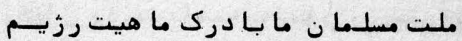

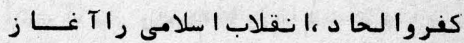

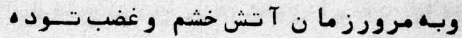

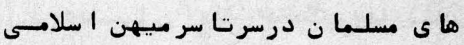

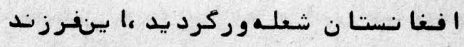

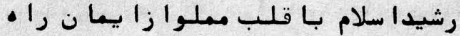

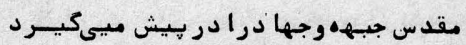

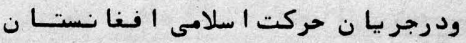




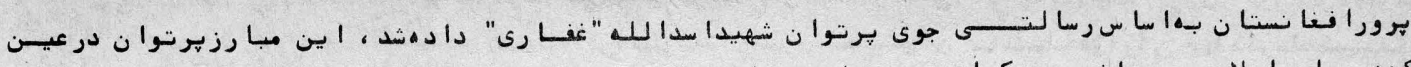

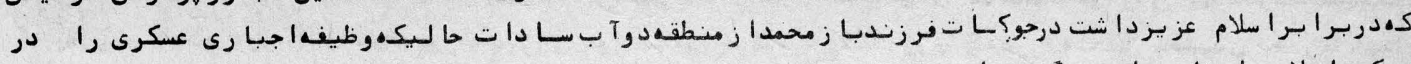

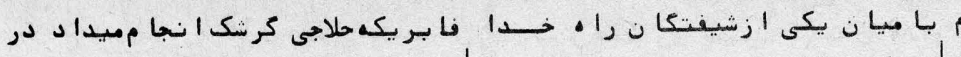

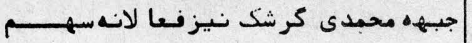

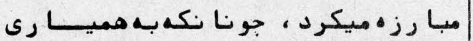

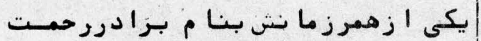

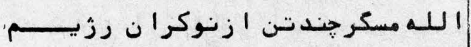

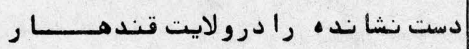

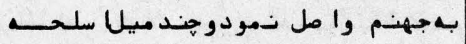

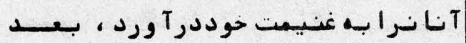

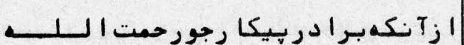

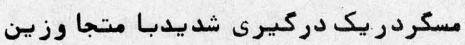

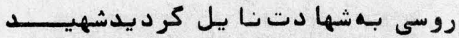

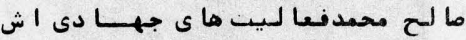
را با جبهـه محمدى تشديدبخشيده وبيكا

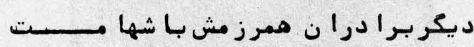

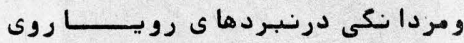

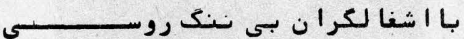

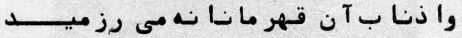

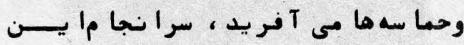

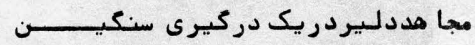

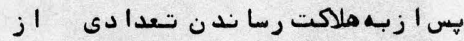

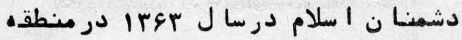

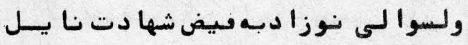

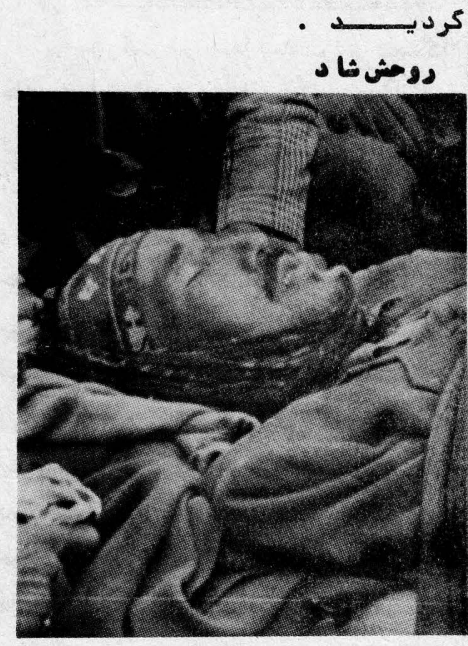

شهيد غلام محمد "حببيبى"

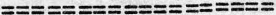

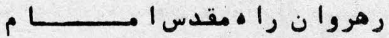

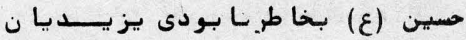

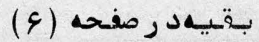

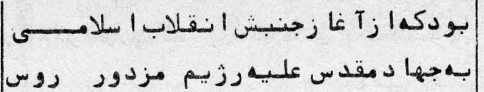

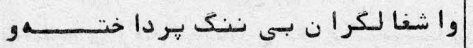

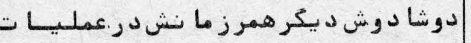

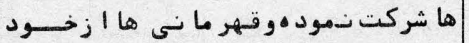

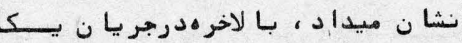

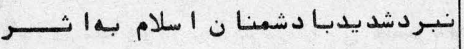

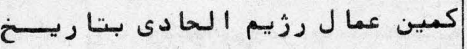

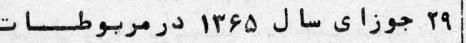

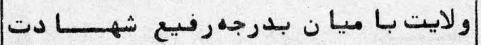
روحش شادبــــاد

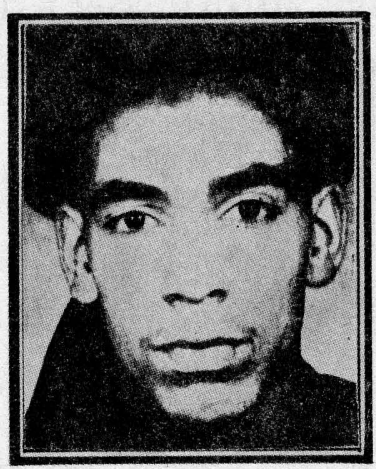

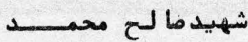

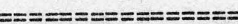

شهيد قهر ما ن برا در ما لـمحمعد

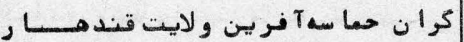

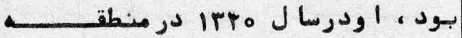

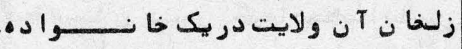

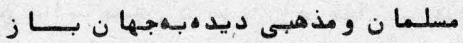

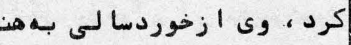

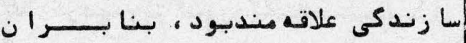

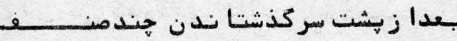

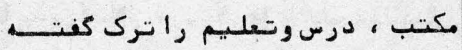

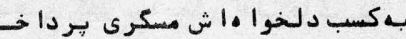

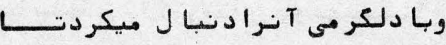

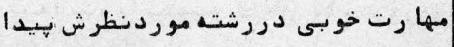

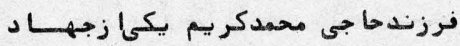

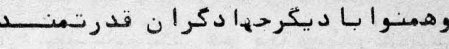

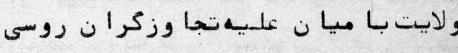

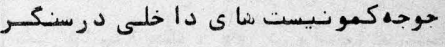

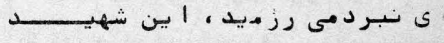

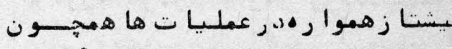

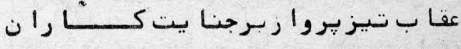

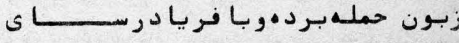

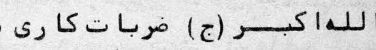

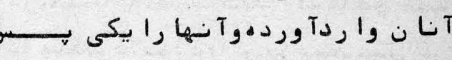

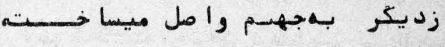

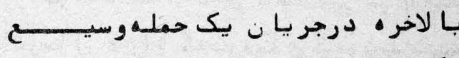

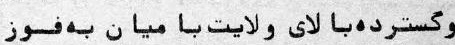

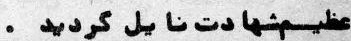

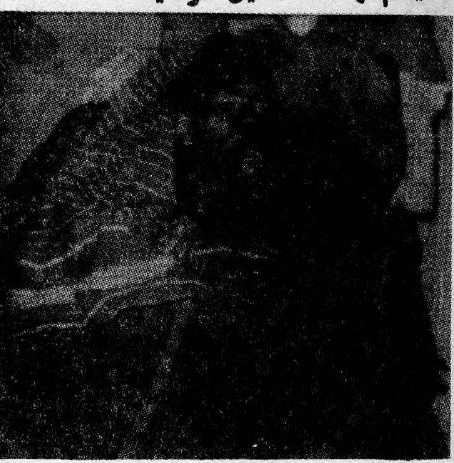

شهيد حما سه سا ز"ا سدا للـ غفا رى

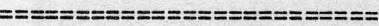
مهم تر ين عوا ملى كيبها نسا ن

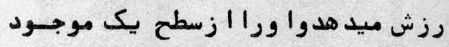

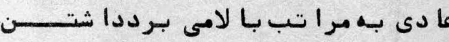

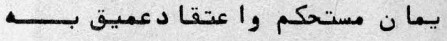

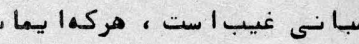

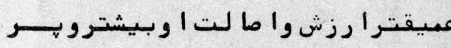

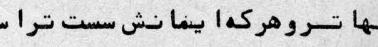

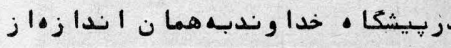

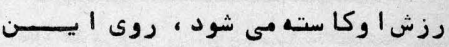

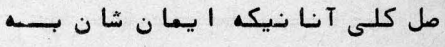

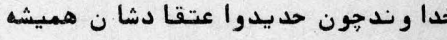

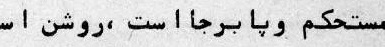

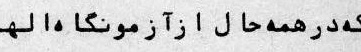

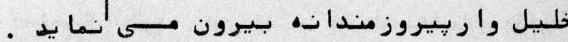

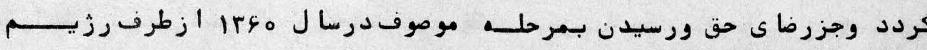

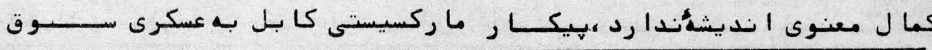



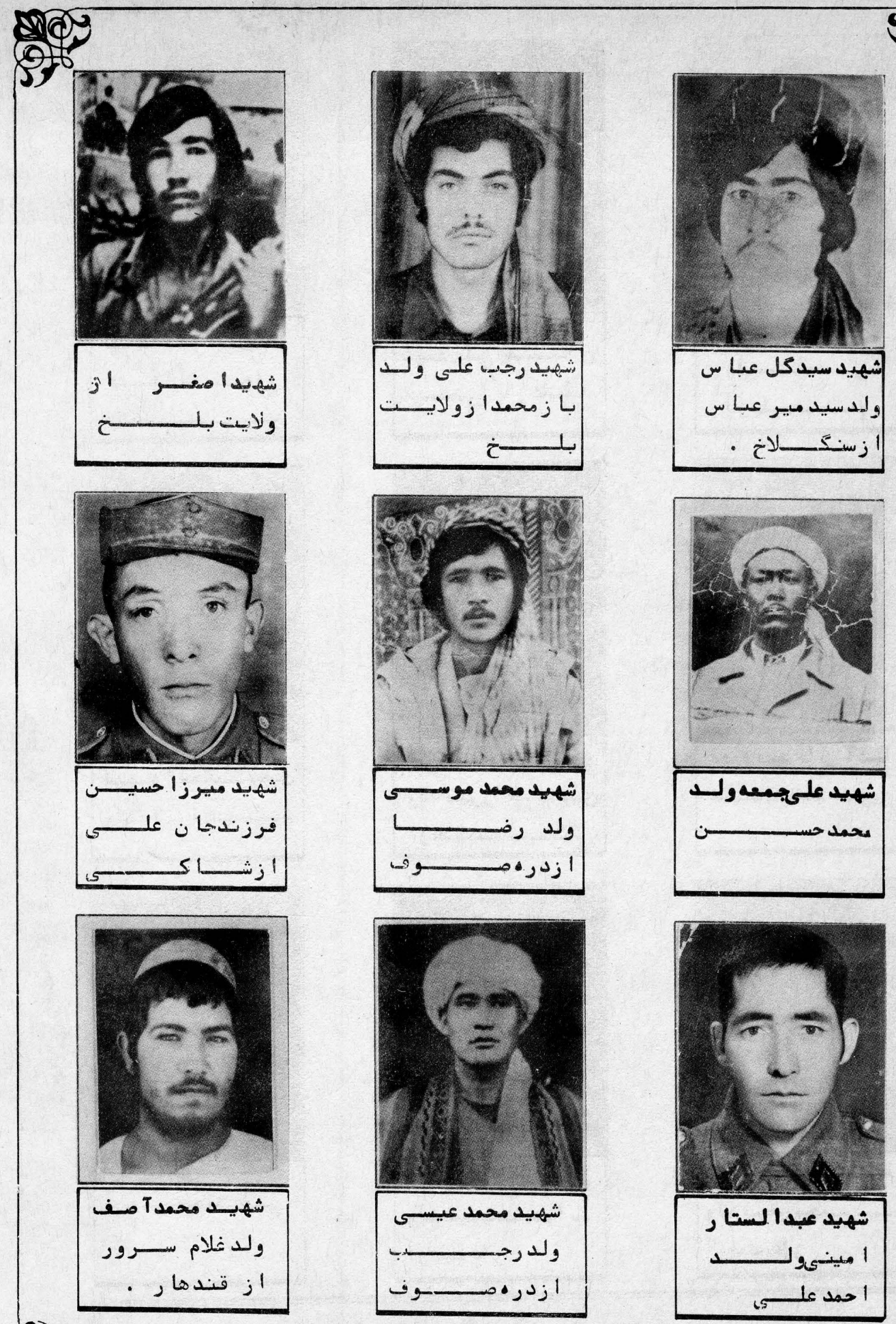


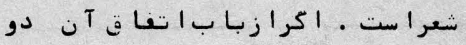

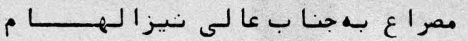

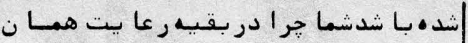
وزن وقافيهرا نكردها يد ؟ موفقيست

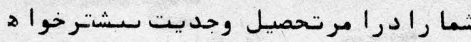

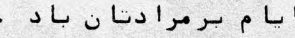

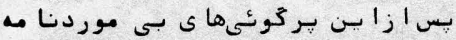

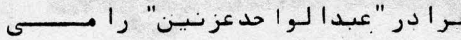

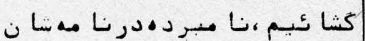

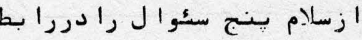

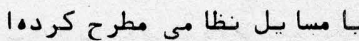

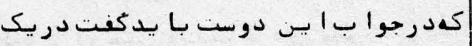

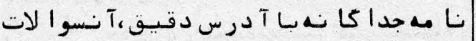

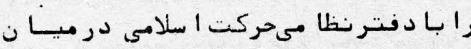

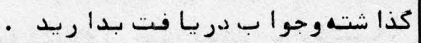

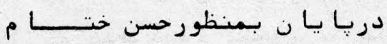

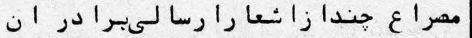

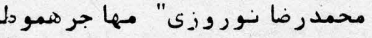
مقيـمقـمو " مير ا حمدشا •شمس "عموطــن

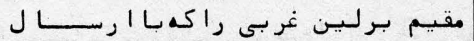

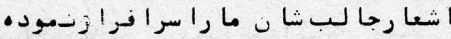

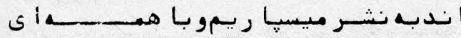

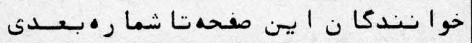

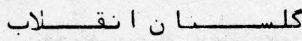

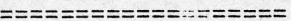

ازمحمدر ما نوروزى :

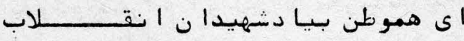

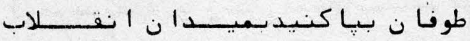

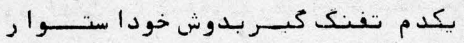

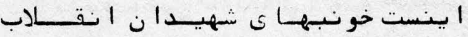

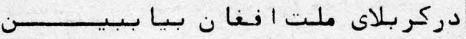

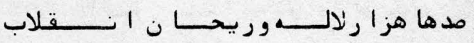

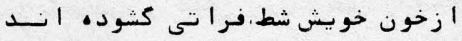

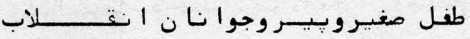

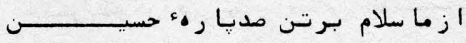

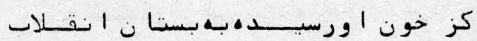

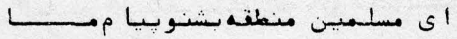

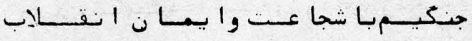

$$
\text { ....... }
$$

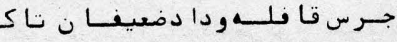

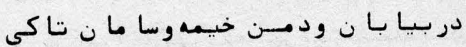

(c)

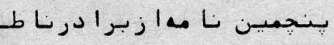

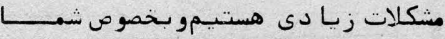

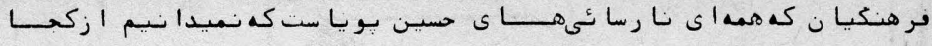

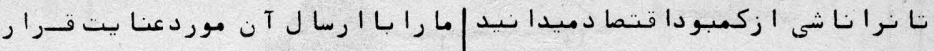
من

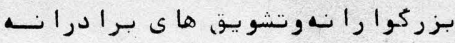

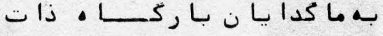

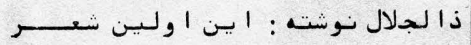

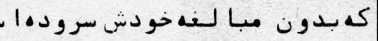

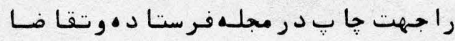

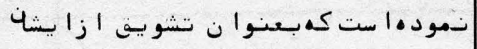

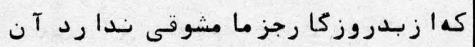

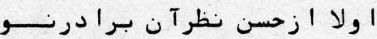

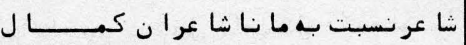

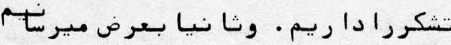

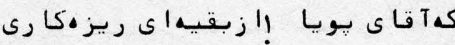
با زا رشعروشا عرى كه بكذريم خوبس ريس

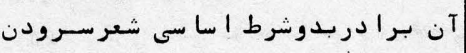

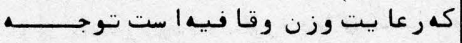

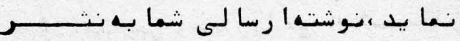

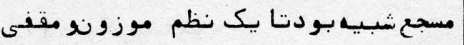

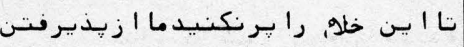

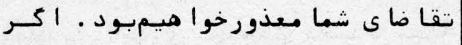

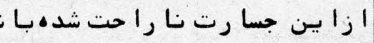

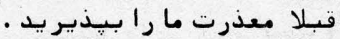

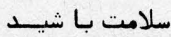

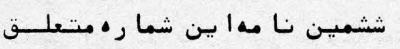

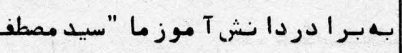

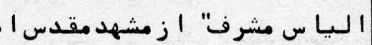

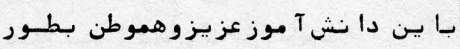

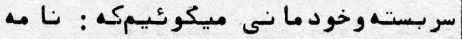

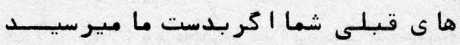

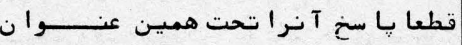

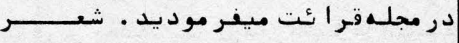

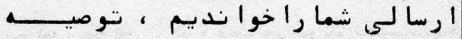

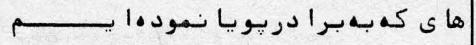

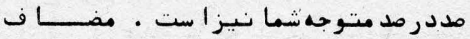

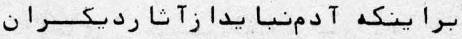

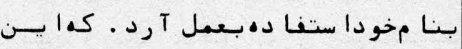

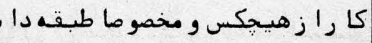
T موزكنا هيست نا بخشو دنى إنى

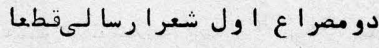

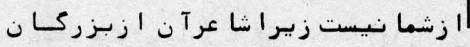

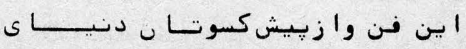

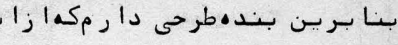

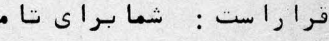

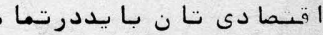

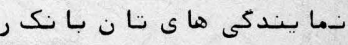

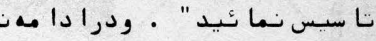

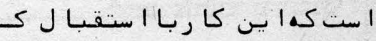
مها جرين موا جه خوا هدشدوآ نـها

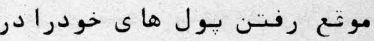

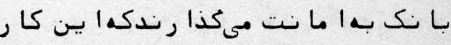
هم موجب رورنق با زا رشما ميكرددورهـم

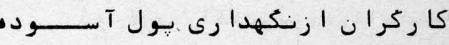

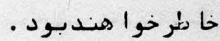

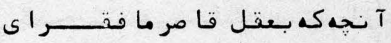
خا كسا ر مير سدا يـست كه خودر ادرخسـور

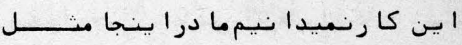

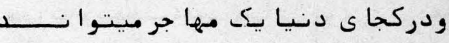

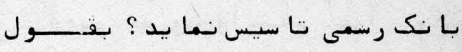

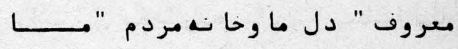

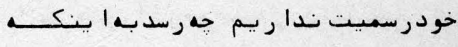

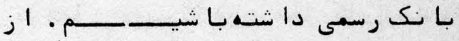

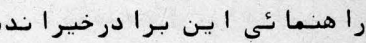

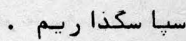

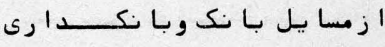

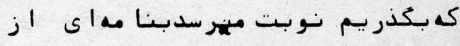

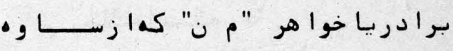

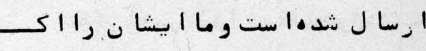

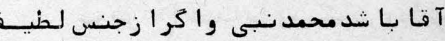

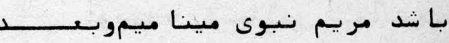

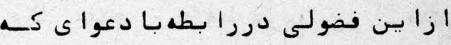

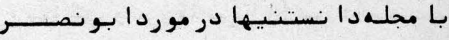

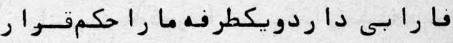

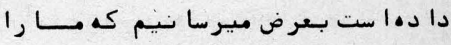

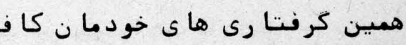

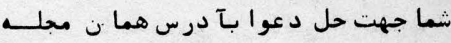

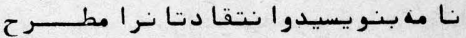

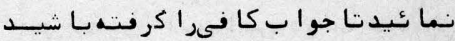

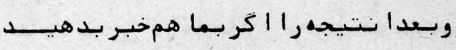
ازشما معنون خوا هيمبود ـ.

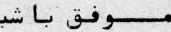

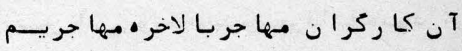




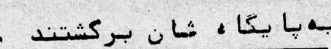

دركيرى شديدبين خلققى هـا

و بـرجمــــــ

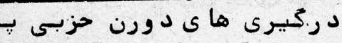

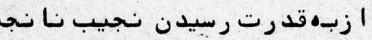

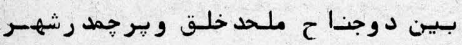

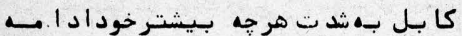

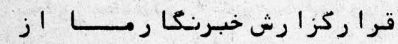

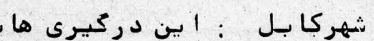

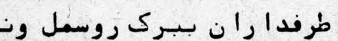

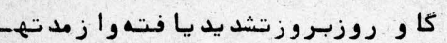

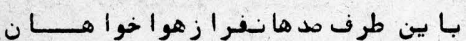

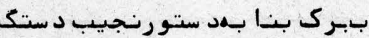

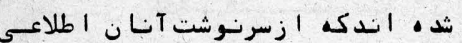

درد ست نديست

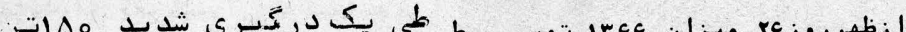

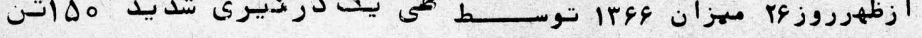

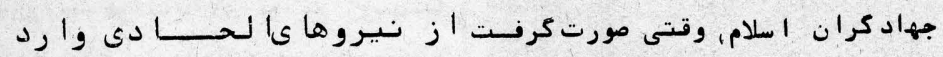

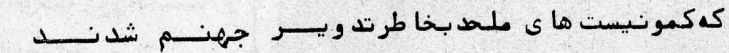

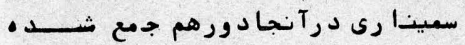

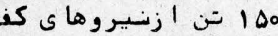

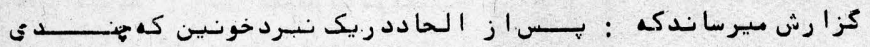

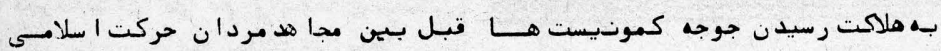

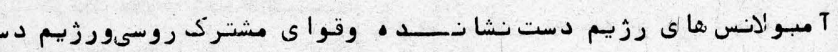

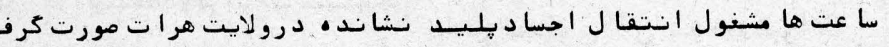

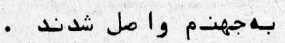

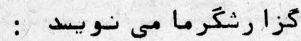

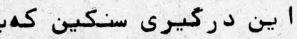

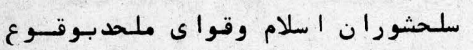

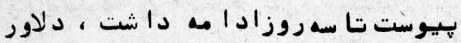

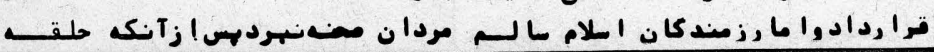

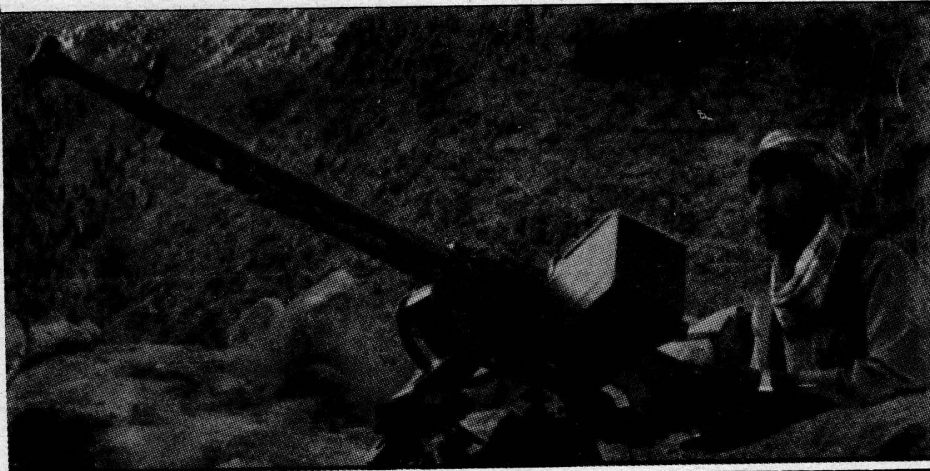

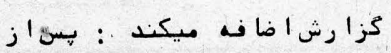

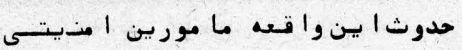

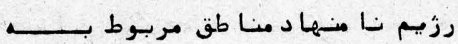

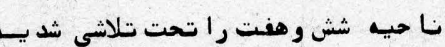

ن

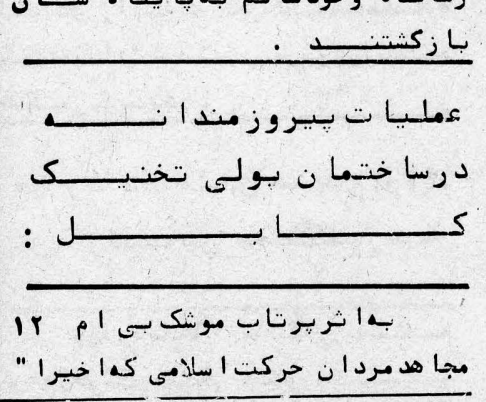

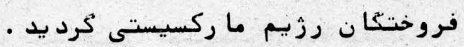

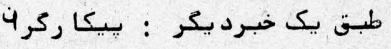

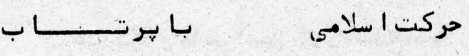

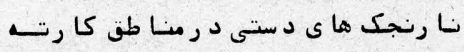

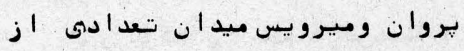

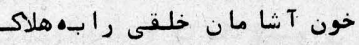

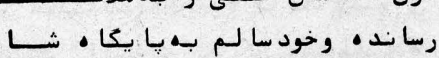

بمب كذا رى در محل ك كـــرو

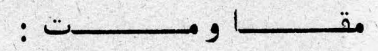

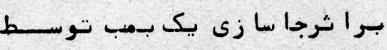

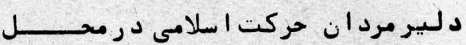

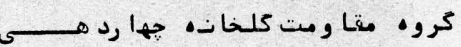

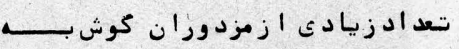

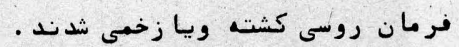

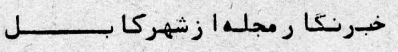

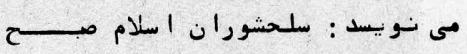

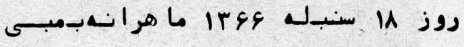
راد رمحل مز بـورجا سا زى نمود مبـودند

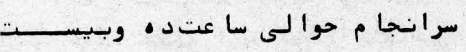

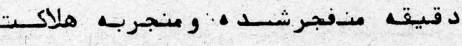

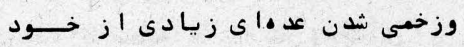
. 


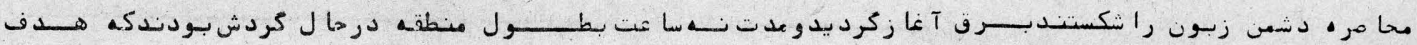

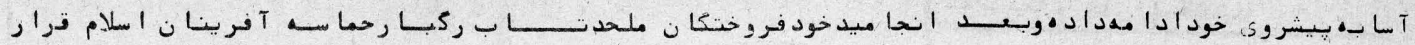

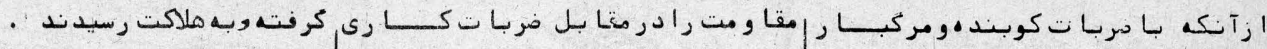

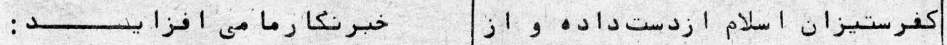

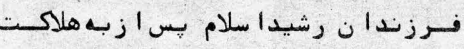

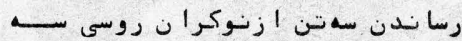

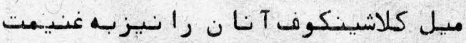

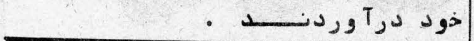

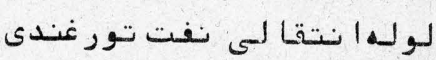
:

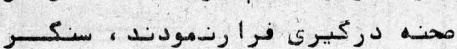
4

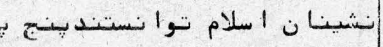

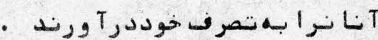

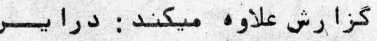

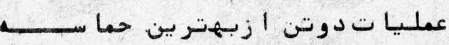

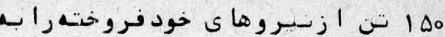

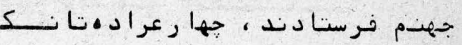

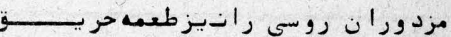

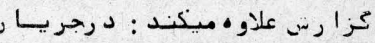

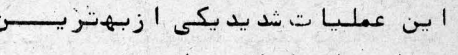

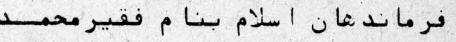

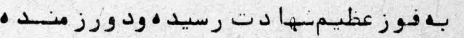

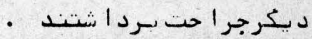

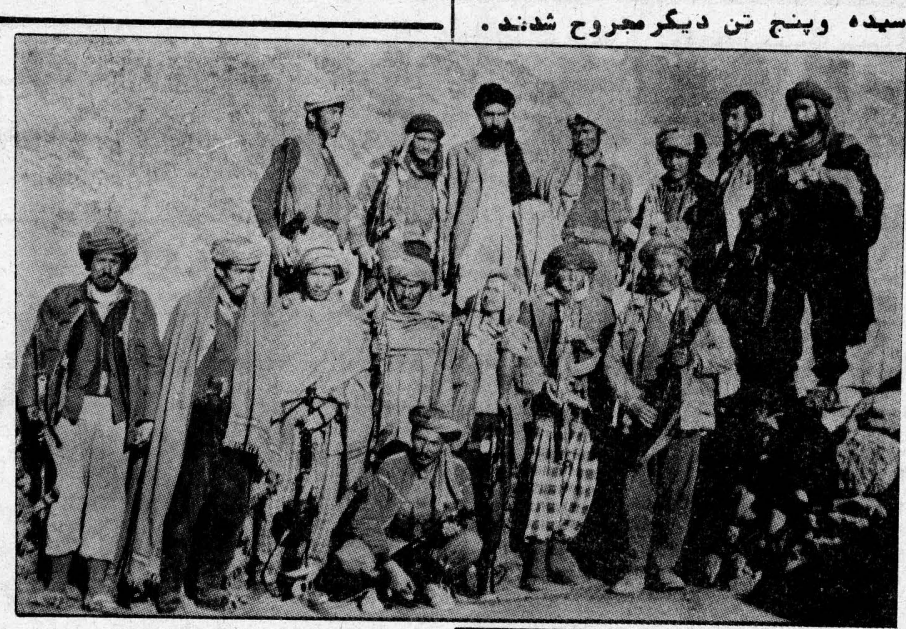

جها دكرا' ن حركمت ا سلامى اخيرا

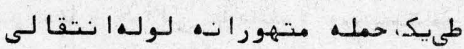
قو ما نـدا ن بستهمخوشى لـوكــر

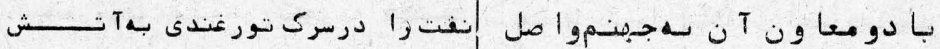

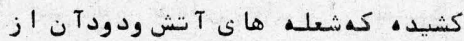

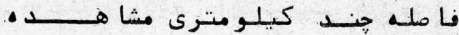

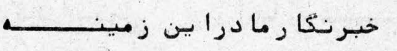

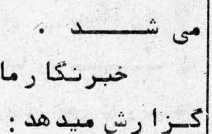

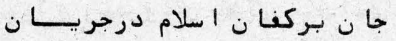

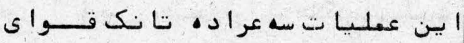

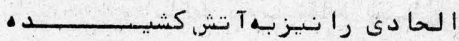

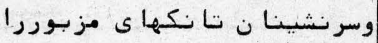

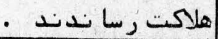

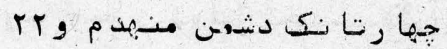
تن 1 ز ملحد بين به نلاكت رسيد

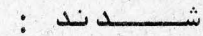

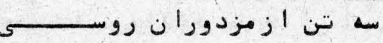

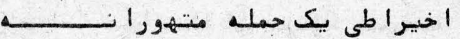

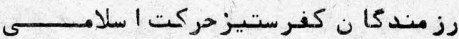

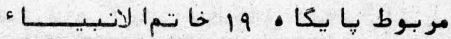

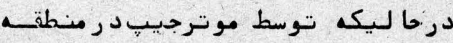

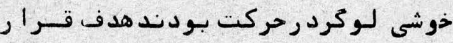

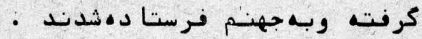
خبر نكا ر مجلـه كزا رش ميد هد :

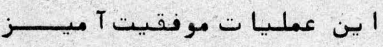

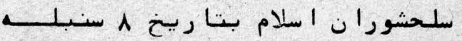
ـ

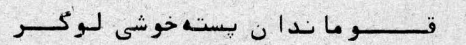

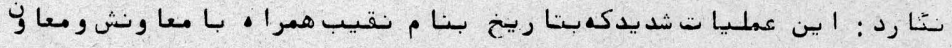

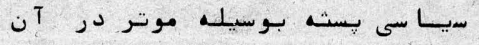

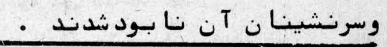

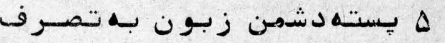

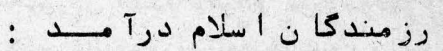

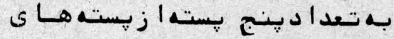
رزيم ما ركسيستى كا بـل درو لايه

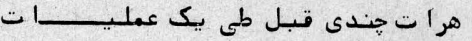

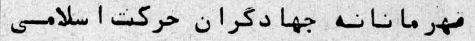

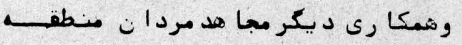

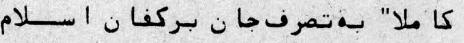
$\underset{ }{\top}{ }^{\top}$

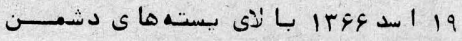

طى يك عمليا ت 1 تن ازكفا ر روسى بـهـهنم رفئم

ن ا

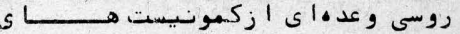

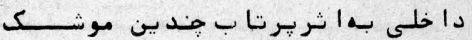

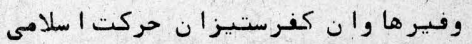

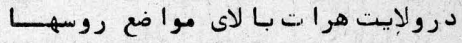

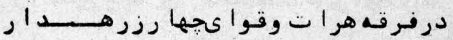

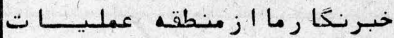

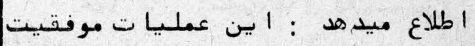

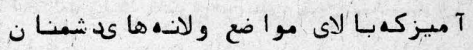
ا سلام صورت كرفت علاو ها زبه هلاك

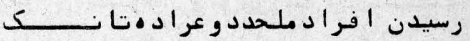

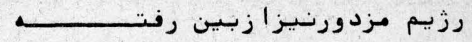

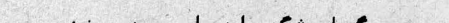


يكتن ازخلقتى هاى ملحدبها ثر

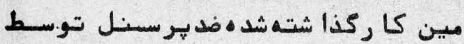

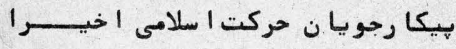

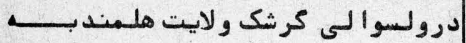

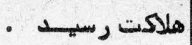

خبرنكا رما اطلاع ميد هد :

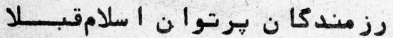

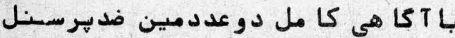

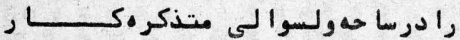

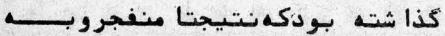
اثرَن يكتن ا زجوجهكمونيست هــــاء

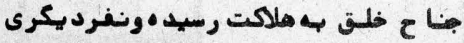

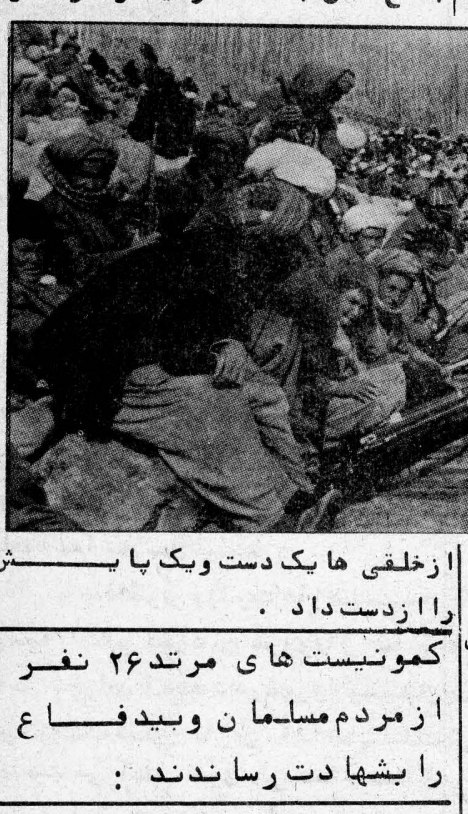

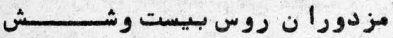

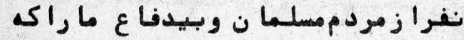

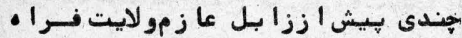

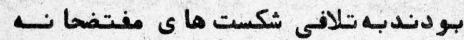

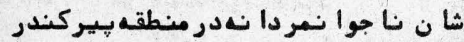

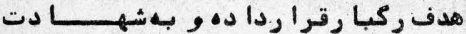

بكز ا رش خبرنغا ر ما ا زولاي

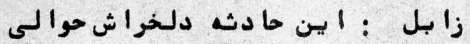

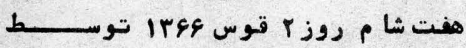

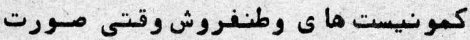

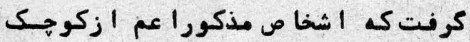

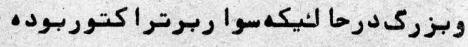

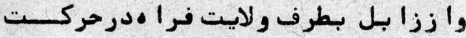

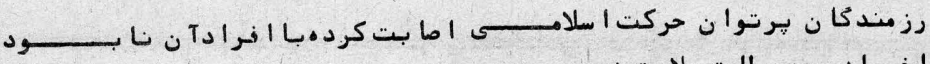

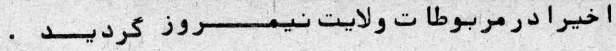

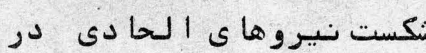
$: 5$

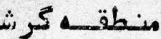

طى يك عمليا ت شديدكه توسيط

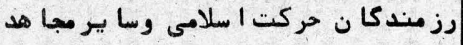

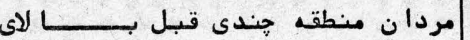

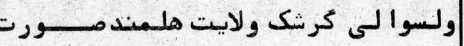

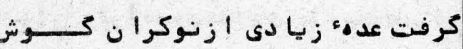

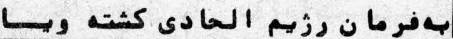

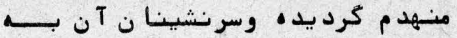

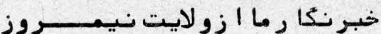

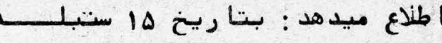

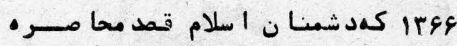

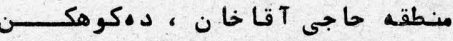

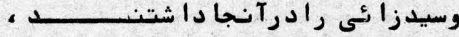

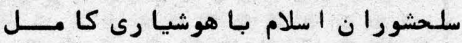

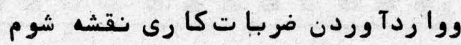

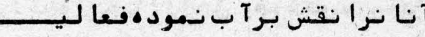

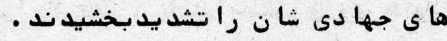

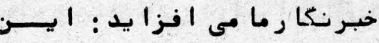

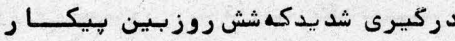

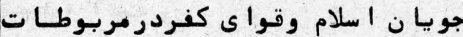

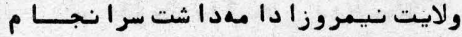

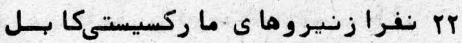

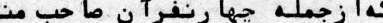
بودندبه جهنم واطل كرديدهوعدهاى

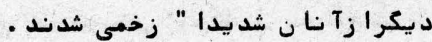

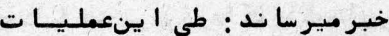

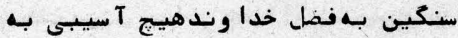
جا ن بركفا نا سلامنرسيده سا لـمبهه يا يكاه

خبرنكا رما ا طلاع ميدهد : زخمى شدند.

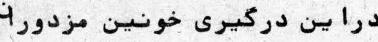

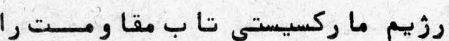

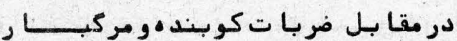

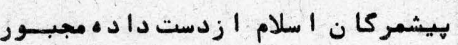

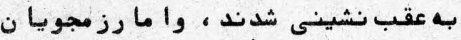

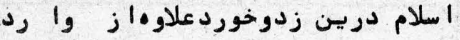

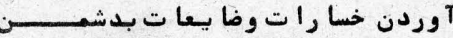

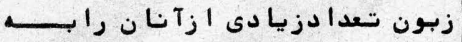

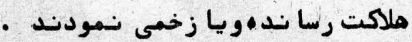

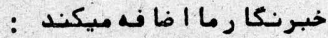

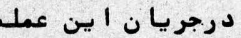

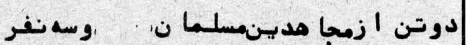

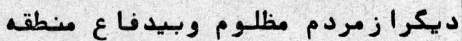

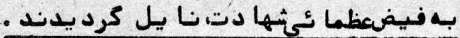
يكتن ازخلقتها به هلاك رسيدهوريك تن مجروحكرد يد :

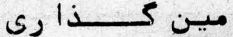

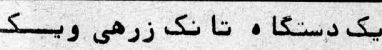

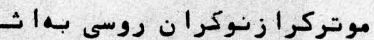

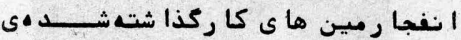

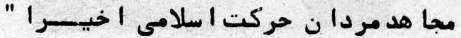

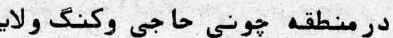

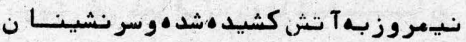
آن به هلاكت رسيدند كزا رشكر مجلها زولايت نيعــروز

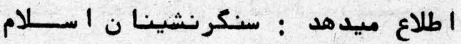

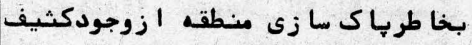

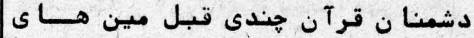

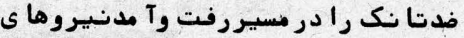

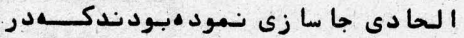

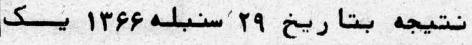
دستكا • تانك ويك موتركر ا زد شمهـن

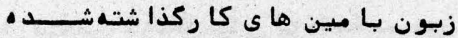




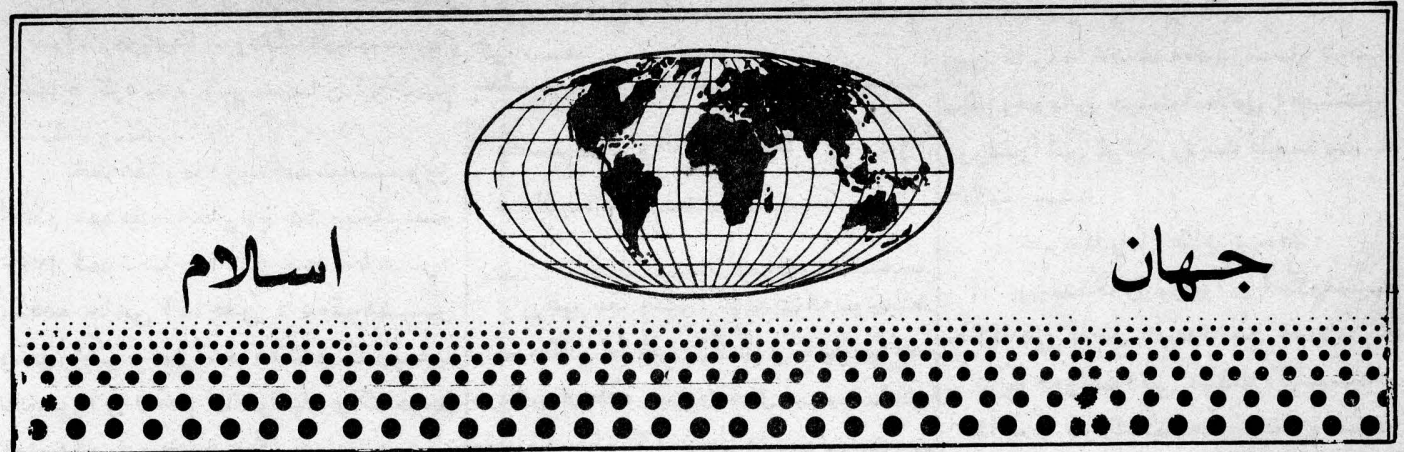

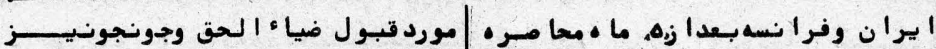

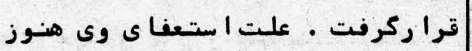

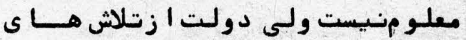

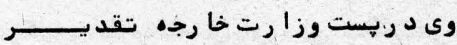

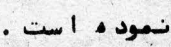

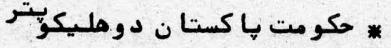

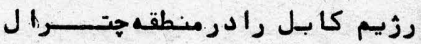

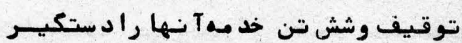

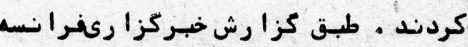

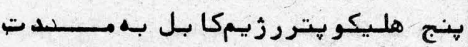

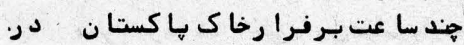

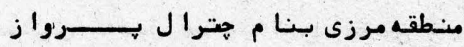

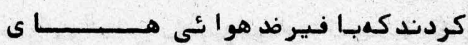

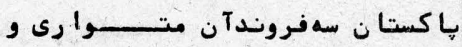

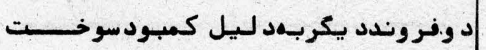

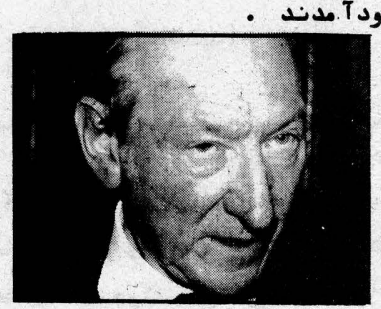

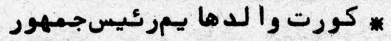

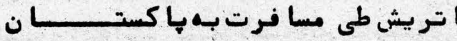

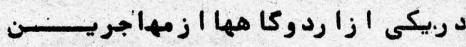

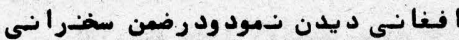

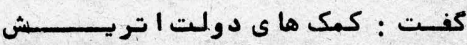

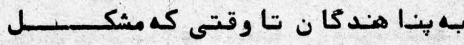

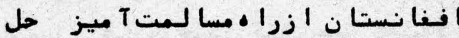

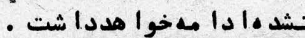
عربستان

حكومت سعودى درنظــــ

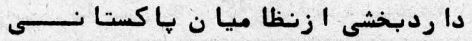

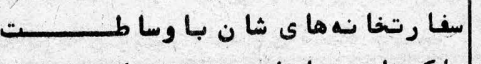

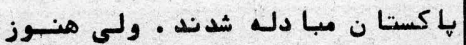

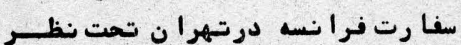

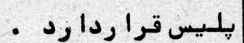

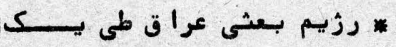

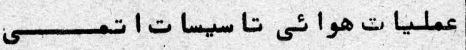

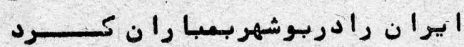

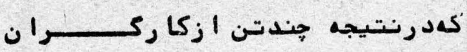

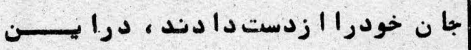

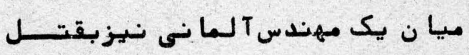

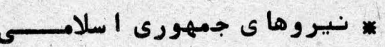

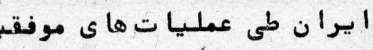

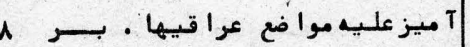

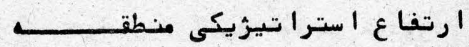

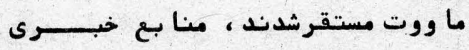

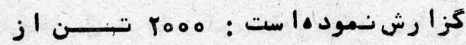

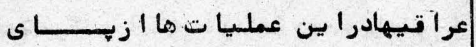

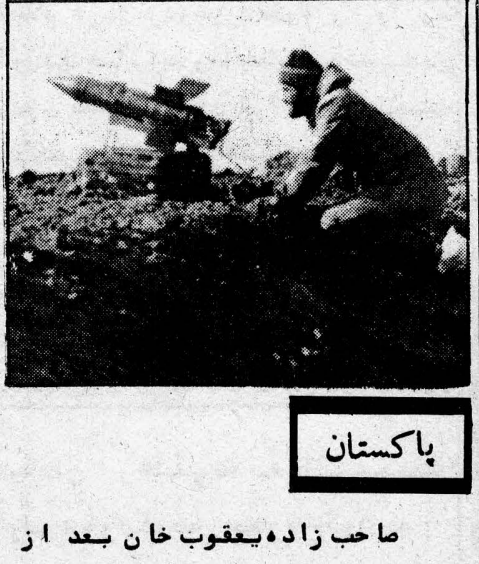

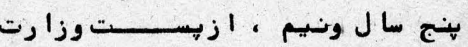

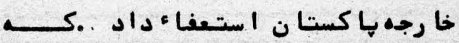

ايران

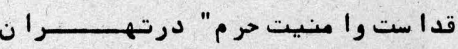

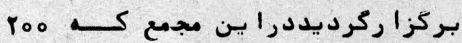

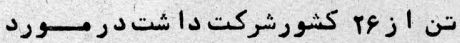

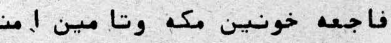

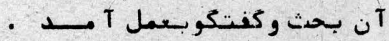

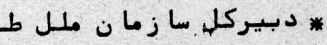

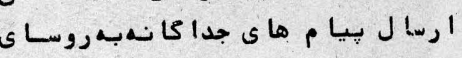

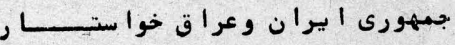

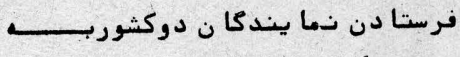

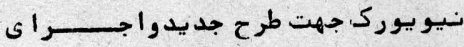

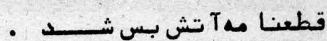

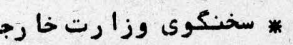

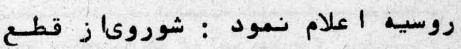

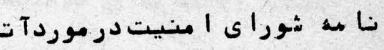
بس درجنـ خليج فا رس بـ با قا طعي

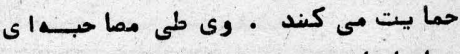

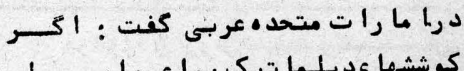

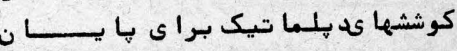

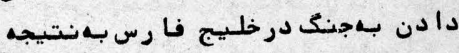

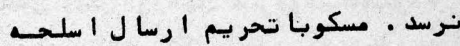

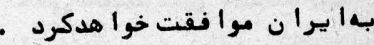

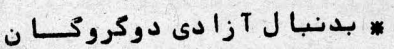

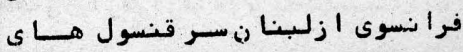

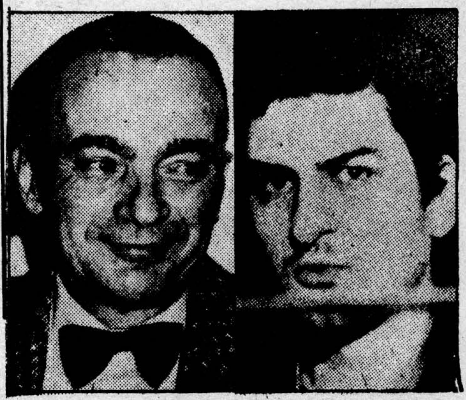

استقا مت (q0) 


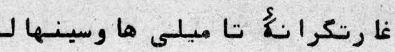

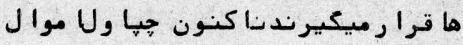

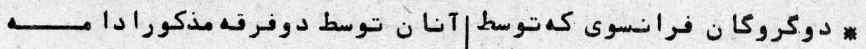

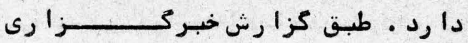

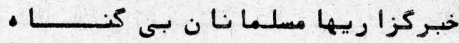

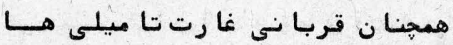

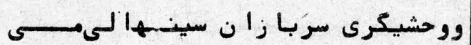

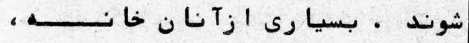

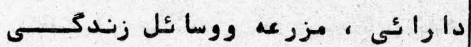

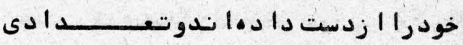

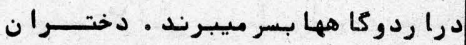

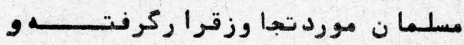

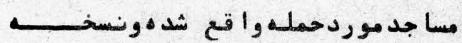

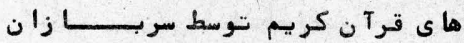

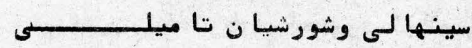

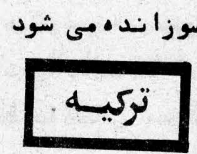

توركوت أوزال ل مدرا عظم تركيه

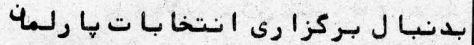

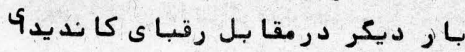

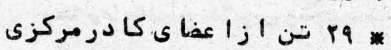

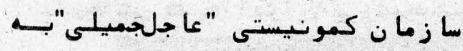

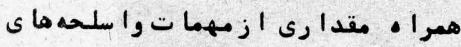

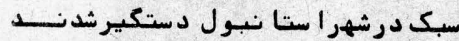

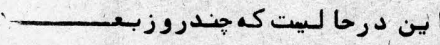

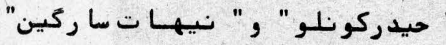

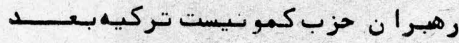

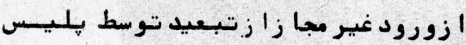

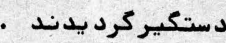

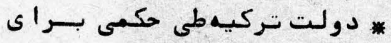

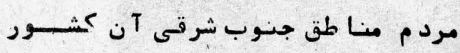

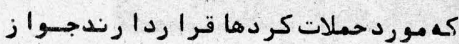

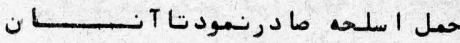

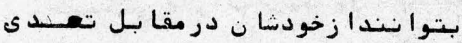

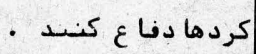

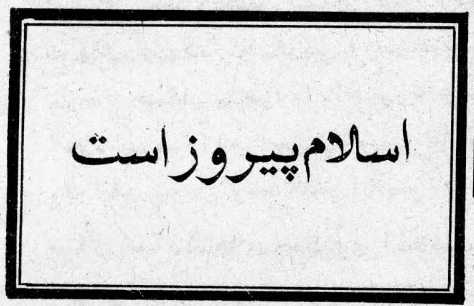

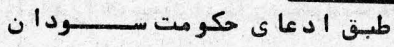

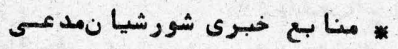

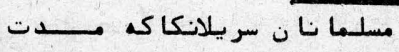

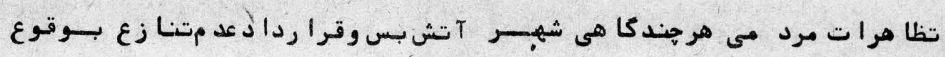

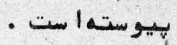

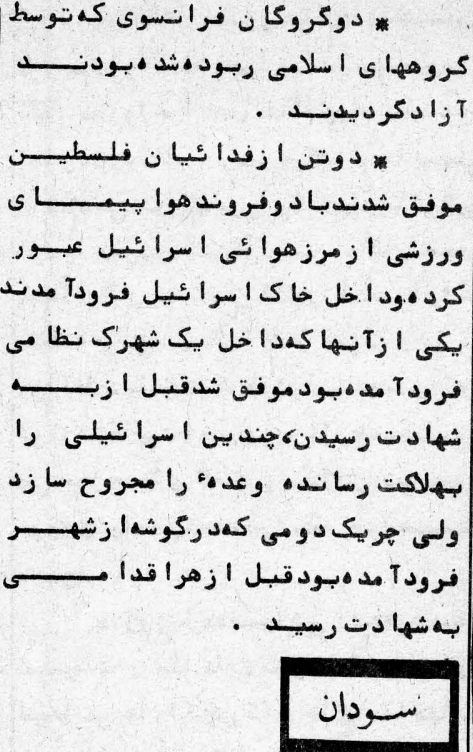

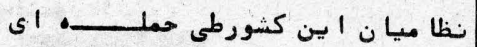

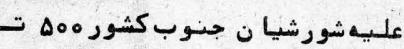

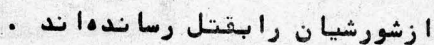

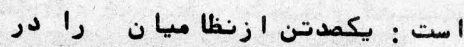

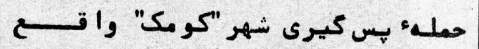

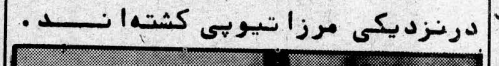
(1.2.

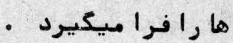

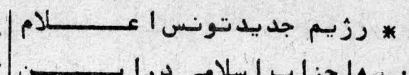

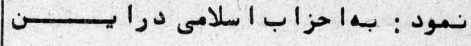
كشور ا جا ز هركت در را مورسيا سى كشور

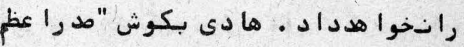

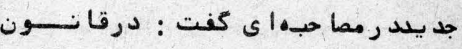

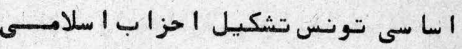

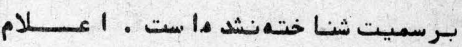

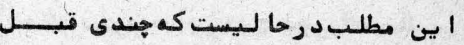

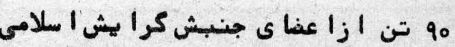

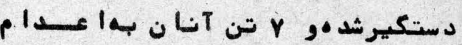

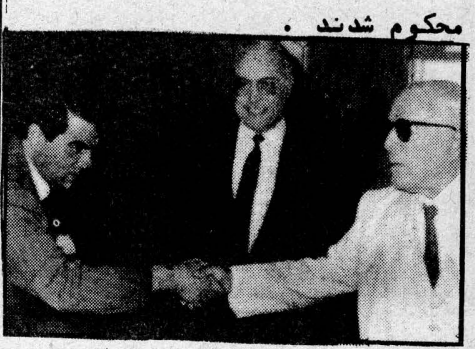

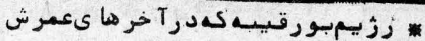

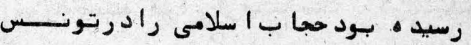

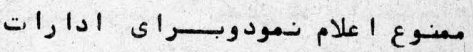
دوبلتى بخشنا مهاى ماد دركردكم زنهـا

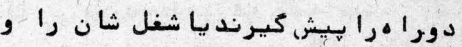

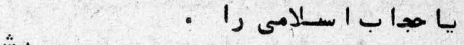

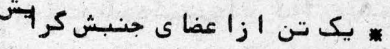

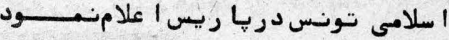

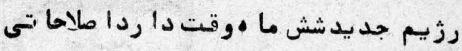

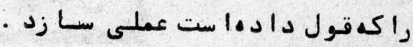

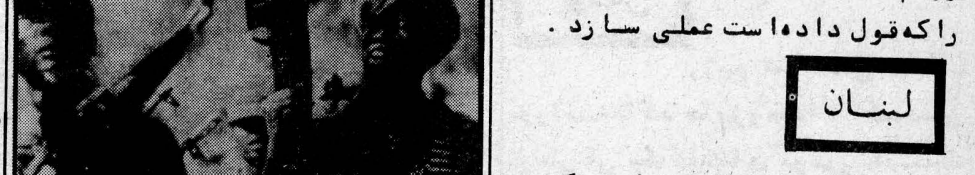

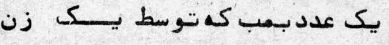

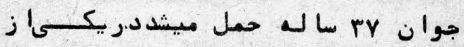

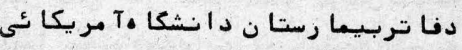

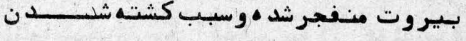

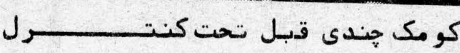

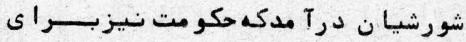

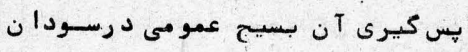

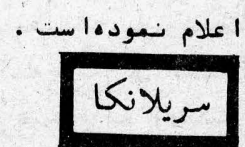

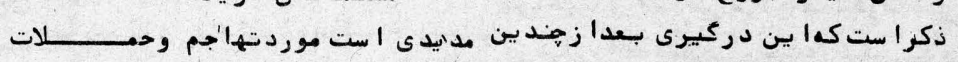




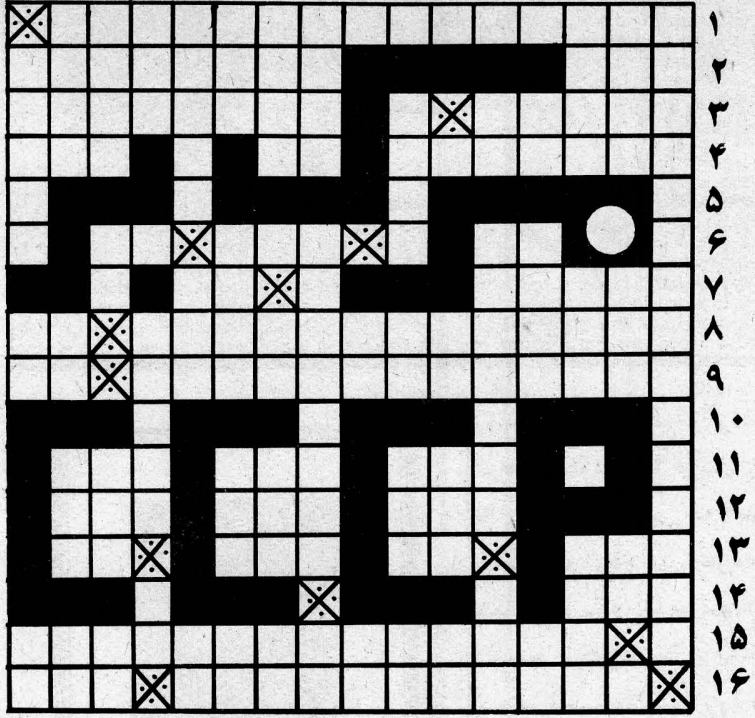

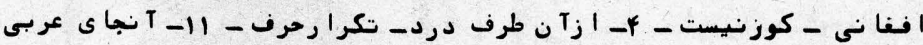

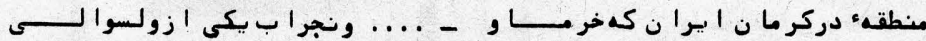

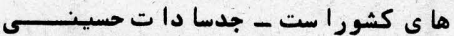

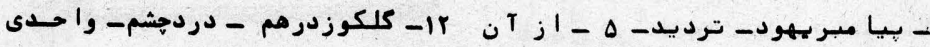

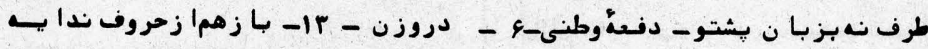

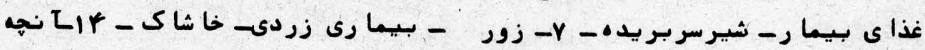

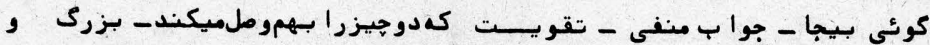

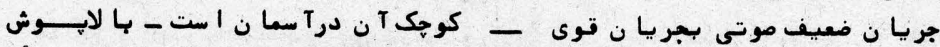

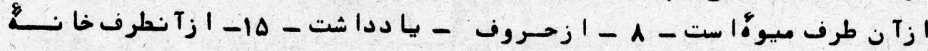

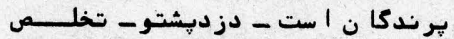

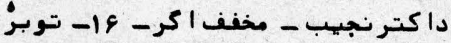

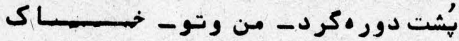

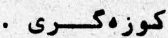

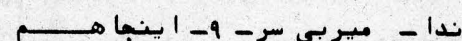

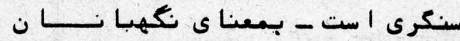

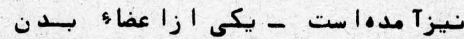

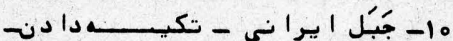

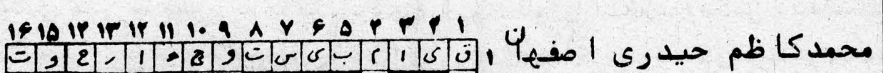

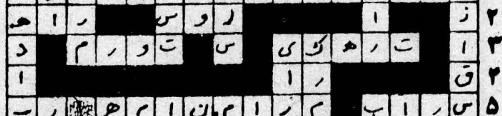

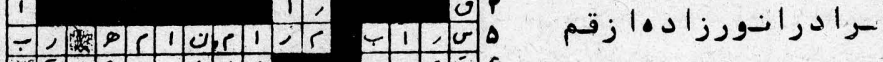

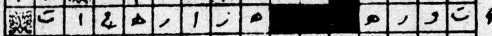

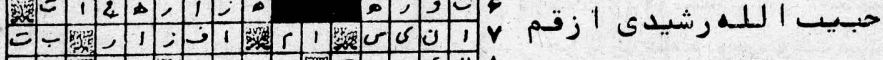
ن ज t

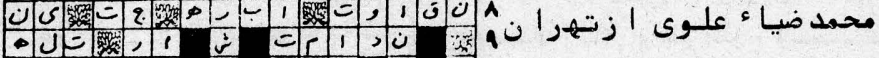
محمد على صا برى از از

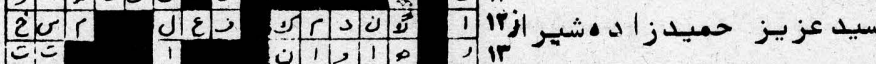
محمد عز يز قروسانى مشيهـ 1.5 ن 1 C 011,2 is

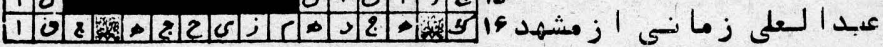

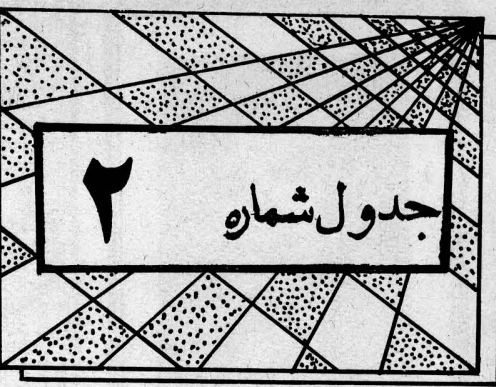

ا فقـى :

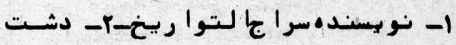

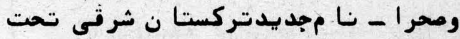

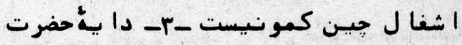

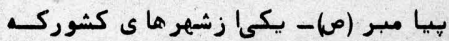

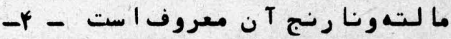

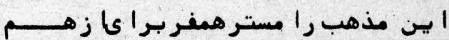

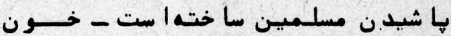

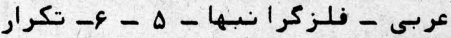

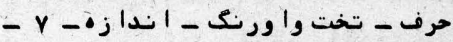

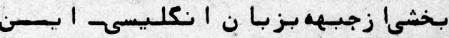

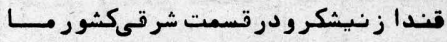

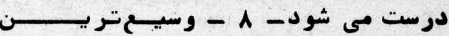

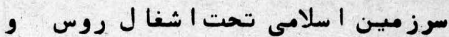

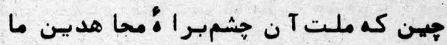

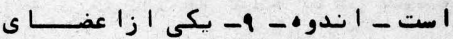
برجسته شوراى مركزى حركت أسلامسى

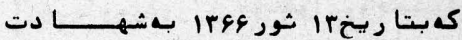

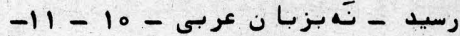

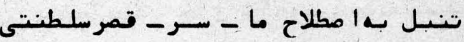

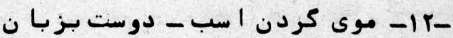

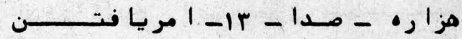

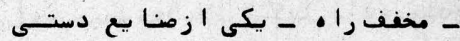

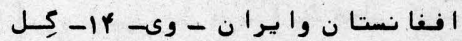

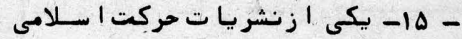

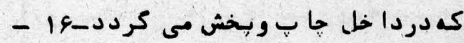

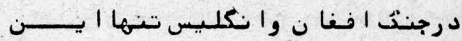

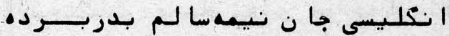

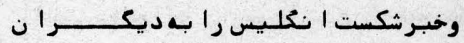

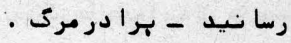
عمودى :

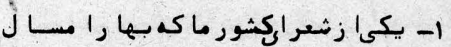

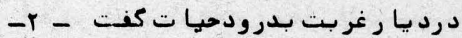

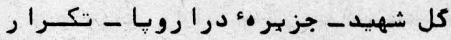

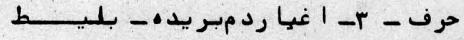

